\title{
ARCHAEOLOGICAL INVESTIGATIONS ON THE BUCKBOARD MESA ROAD PROJECT
}

\author{
by \\ Daniel S. Amick \\ Gregory H. Henton \\ Lonnie C. Pippin \\ with contributions by \\ Alvin R. McLane \\ Janis Klimowicz \\ Laurie A. Walsh \\ Technical Report No. 69 \\ Prepared for \\ U.S. Department of Energy \\ Field Office, Nevada \\ Las Vegas, Nevada
}

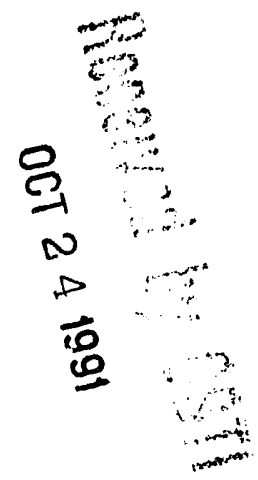

October 1991
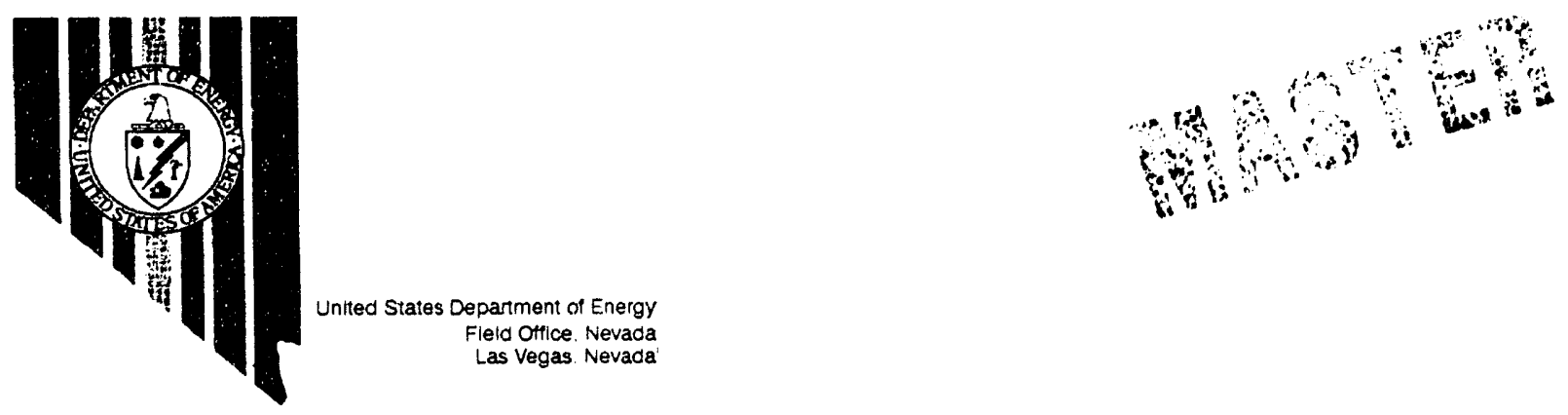

The work upon which this report is based was supported by the U.S. Department of Energy under Contract \#DE-AC08-85NV10384 
This report was prepared as an account of work sponsored by the United States Government. Neither the United States nor the United States Department of Energy, nor any of their employees, makes any warranty, express or implied, or assumes any legal liability or responsibility for the accuracy, completeness or usefulness of any information, apparatus, product or process disclosed, or represents that its use would not infringe privately owned rights. Reference herein to any specific commercial project, process, or service by trade name, mark, manufacturer, or otherwise, does not necessarily constitute or imply its endorsement, recommendation, or favoring by the United States Government or any agency thereof. The view and opinions of authors expressed herein do not necessarily state or reflect those of the United States Government or any agency thereof.

This report has been reproduced directly from the best available copy.

Available to DOE and DOE contractors from the Office of Scientific and Technical Information, PO Box 62, Oak Ridge, TN 37831; prices available from (615) 576-8401, FTS 626-8401.

Available to the public from the National Technical Information Service, U.S. Department of Commerce, 5285 Port Royal Road, Springfield, VA 22161. 


\section{CONTENTS}

ACKNOWLEDGMENTS $\ldots \ldots \ldots \ldots \ldots \ldots \ldots \ldots \ldots \ldots$ vii

1. EXECUTIVE SUMMARY $\ldots \ldots \ldots \ldots \ldots \ldots \ldots \ldots \ldots \ldots \ldots \ldots$

2. THE CONTEXT $\ldots \ldots \ldots \ldots \ldots \ldots \ldots \ldots \ldots \ldots \ldots \ldots \ldots \ldots \ldots \ldots \ldots$

Physiography and Geology

Daniel S. Amick ............................ 2

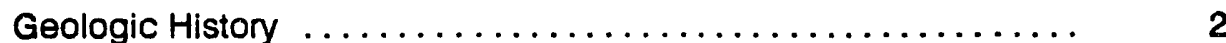

Lithic Resources $\ldots \ldots \ldots \ldots \ldots \ldots \ldots \ldots \ldots \ldots \ldots \ldots \ldots, 4$

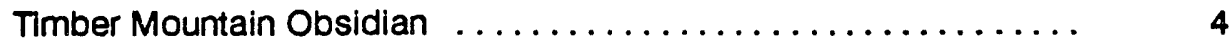

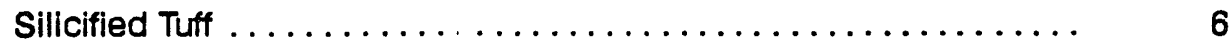

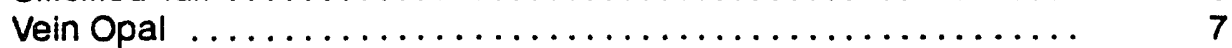

Other Lithic Resources ............................ 7

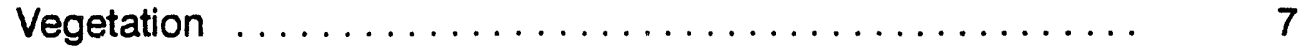

The Cultural Environment

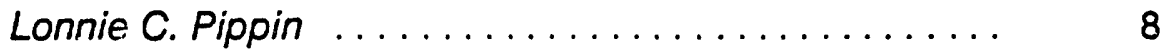

Historic Occupants .............................. 8

Prehistoric Lifeways ......................... 9

3. HISTORY OF THE BUCKBOARD MESA REGION

Alvin R. Mclane ..................... 13

4. PREVIOUS RESEARCH AND PROJECT HISTORY

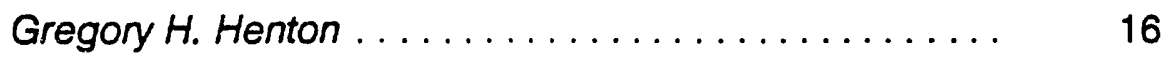

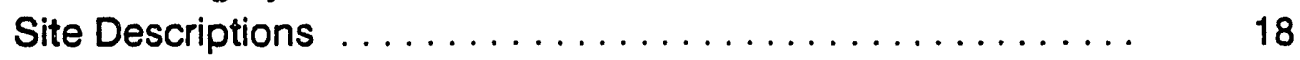

Buckboard Mesa Road, Phase $1 \ldots \ldots \ldots \ldots \ldots \ldots \ldots \ldots . \ldots \ldots$

Buckboard Mesa Road, Phase $2 \ldots \ldots \ldots \ldots \ldots \ldots \ldots . \ldots . \ldots . \ldots 18$

Buckboard Mesa Rim ............................ 20

$18-03$ Road .................................... 23

5. RESEARCH DESIGNS AND METHODS

Lonnie C. Pippin and Gregory H. Henton ........... 25

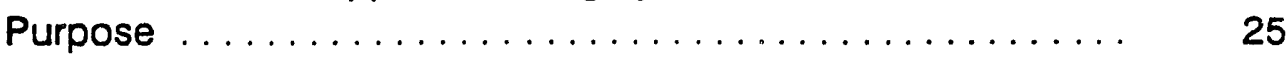

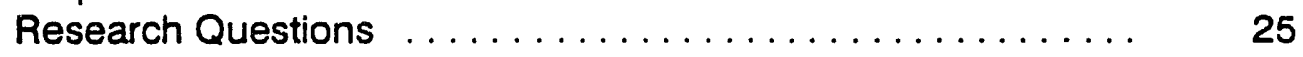

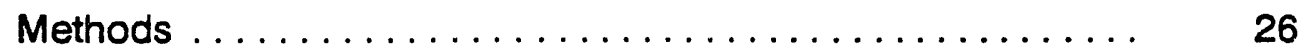

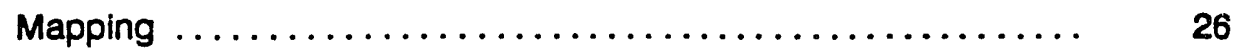

Surface Collection $\ldots \ldots \ldots \ldots \ldots \ldots \ldots \ldots \ldots \ldots \ldots \ldots \ldots, \quad 27$

Subsurface Scrapes ............................... 29

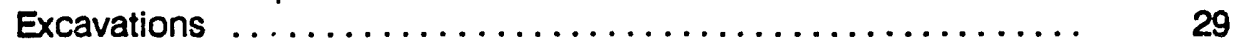

6. SITE 26NY4892: AN OBSIDIAN NODULE QUARRY

Daniel S. Amick ..................... 31

Archaeological Surface History ................. 31

Stratigraphy and Surface Size Sorting Effects $\ldots \ldots \ldots \ldots \ldots \ldots . \quad 31$

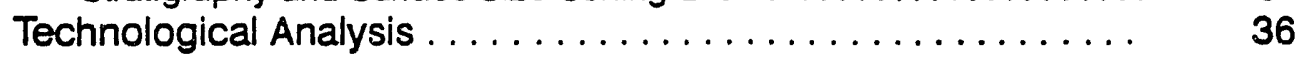

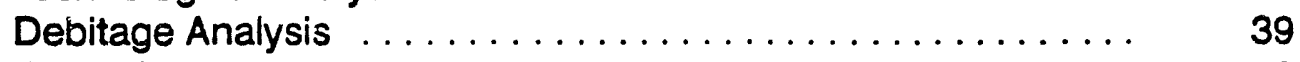

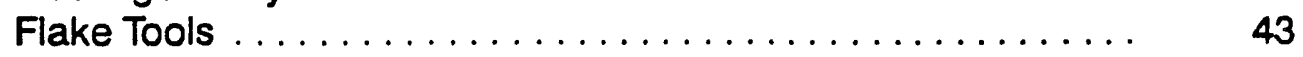

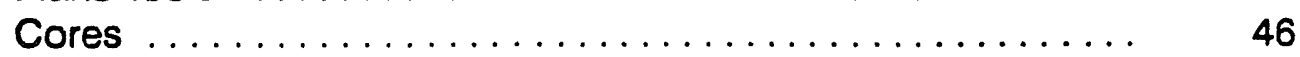

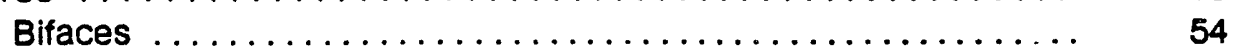

Projectile Points $\ldots \ldots \ldots \ldots \ldots \ldots \ldots \ldots \ldots \ldots \ldots \ldots \ldots \ldots \ldots \ldots$ 
Nonchipped-Stone Artifacts $\ldots \ldots \ldots \ldots \ldots \ldots \ldots \ldots \ldots, 77$

Hammerstones ................................ 77

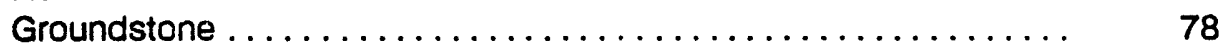

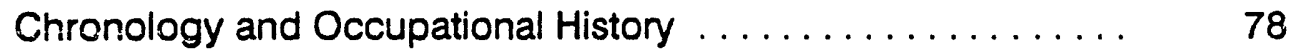

Effects of Reoccupation ................................. 79

Reworked Artifacts .............................. 81

Summary and Discussion . . . . . . . . . . . . . . . 88

Distributional Comparisons ....................... 88

Assemblage Comparisons ...................... 90

7. SITE 26Ny4894: AN OBSIDIAN NODULE QUARRY

Laurie A. Walsh ...................... 93

Surface Collection $\ldots \ldots \ldots \ldots \ldots \ldots \ldots \ldots \ldots \ldots \ldots . \ldots \ldots$

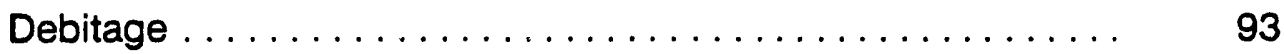

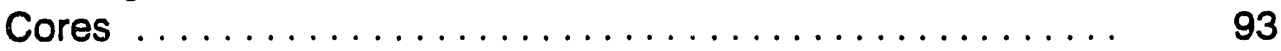

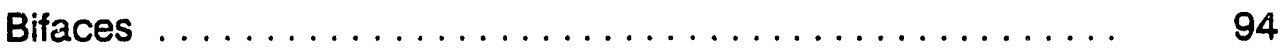

Summary and Discussion ...................... 94

8. THE 18-03 ROAD SITES: OBSIDIAN QUARRY SCATTERS

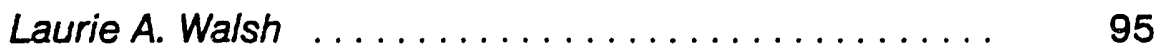

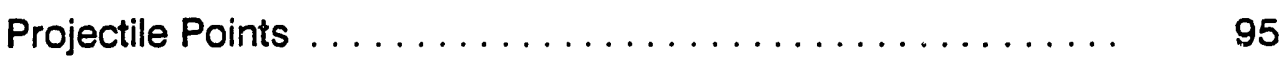

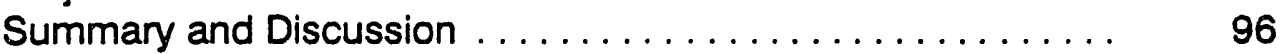

9. OBSIDIAN HYDRATION ANALYSIS OF THE BUCKBOARD MESA ROAD PROJECT SURFACE COLLECTED ARTIFACTS

Janis Klimowicz . . . . . . . . . . . . . . . . . . . . 98

Research Design . . . . . . . . . . . . . . . . . . 98

The Hydration Process $\ldots \ldots \ldots \ldots \ldots \ldots \ldots \ldots \ldots \ldots$

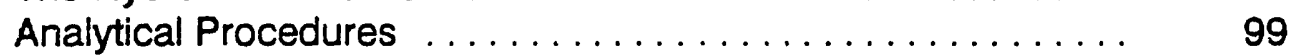

Debitage ..................................... 99

Projectile Points . . . . . . . . .

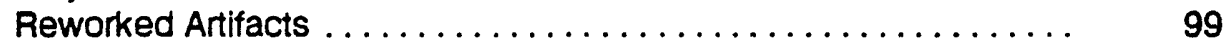

Methodology ............................ 99

Analysis of the Occupational History . . . . . . . . . . . . 103

Projectile Points ............................. 103

Debitage .................................. 104

Reworked Artifacts ................................. 107

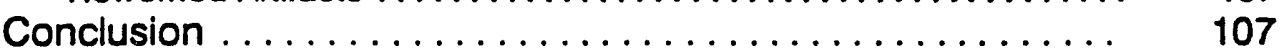

10. SUMMARY AND CONCLUSION

Daniel S. Amick .......................... 110

Spatial Patterning . . . . . . . . . . . . . . . . . . . . . . . 112

Temporal Patterning ............................. 114

Technological Analysis . . . . . . . . . . . . . . . . . . . . . 115

11. MANAGEMENT RECOMMENDATIONS ............... 117

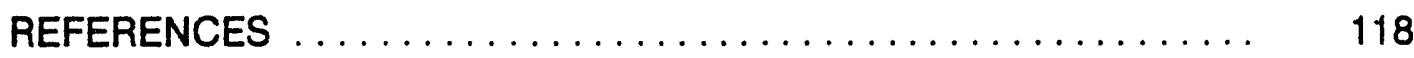




\section{FIGURES}

Figure 2-1. Location of the Nevada Test Site and the

Buckboard Mesa Road Project.

Figure 4-1. Lower portion of the Buckboard Mesa Road and 18-03

Road survey and archaeological sites. ............... 17

Figure 4-2. Overview of $26 \mathrm{Ny} 4892$ and the Buckboard Mesa roads from Buckboard Mesa. .......................... $\quad 19$

Figure 4-3. Rockshelter 26 Ny5222 along Buckboard Mesa rim......... 21

Figure 4-4. Rockshelter 26 Ny5224 along Buckboard Mesa rim. .......... 22

Figure 4-5. Rockshelter 26 Ny5225 along Buckboard Mesa rim. ......... 22

Figure 4-6. Rock art at $26 \mathrm{Ny} 5227$ along Buckboard Mesa rim. .......... 23

Figure 4-7. Rockshelter $26 \mathrm{Ny} 5229$ along Buckboard Mesa rim. ......... 24

Figure 6-1. Main surface collection area at Site 26Ny4892. .......... 31

Figure 6-2. North profile of excavation Unit 1 at 26 Ny4892. ........... 32

Figure 6-3. Histogram of size grade distributions for surface and subsurface artifact assemblages from the excavation units at $26 \mathrm{Ny} 4892 . \ldots \quad 34$

Figure 6-4. Debitage classification key. .................... 41

Figure 6-5. Flake tools from 26 Ny4892. . . . . . . . . . . . . . 45

Figure 6-6. Obsidian assayed cores from 26 Ny $4892 \ldots \ldots \ldots \ldots \ldots \ldots . . \ldots . \ldots$

Figure 6-7. Obsidian unidirectional cores from $26 \mathrm{Ny} 4892 \ldots \ldots \ldots \ldots \ldots . . \ldots 48$

Figure 6-8. Obsidian subconical cores from $26 \mathrm{Ny} 4892 \ldots \ldots \ldots \ldots \ldots \ldots . \ldots . \ldots . \ldots$

Figure 6-9. Obsidian bidirectional cores from $26 \mathrm{Ny} 4892 \ldots \ldots \ldots \ldots \ldots . . \ldots$

Figure 6-10. Obsidian multidirectional cores from $26 \mathrm{Ny} 4892 . \ldots \ldots \ldots \ldots .50$

Figure 6-11. Obsidian late stage bifaces from 26 Ny4892. ........... 56

Figure 6-12. Obsidian early stage bifaces (nodule blanks) from 26Ny4892. . . 56

Figure 6-13. Obsidian early stage bifaces (split nodule blanks) from

26Ny4892. ................................... 57

Figure 6-14. Obsidian early stage bifaces (split nodule blanks) from

26Ny4892. Obverse side. ........................ 57

Figure 6-15. Obsidian intermediate stage bifaces (edged flake blanks) from

26Ny4892. Ventral face. ......................... 58

Figure 6-16. Obsidian intermediate stage bifaces (edged flake blanks) from

26Ny4892. Dorsal face. ........................ 58

Figure 6-17. Obsidian early stage bifaces (indeterminate blanks) from

26Ny4892. .............................. 59

Figure 6-18. Chert/chalcedony late stage bifaces from 26Ny4892. ....... 67

Figure 6-19. Vein opal late stage bifaces from 26 Ny4892. ............ 67

Figure 6-20. Non obsidian projectile points.. .................. 70

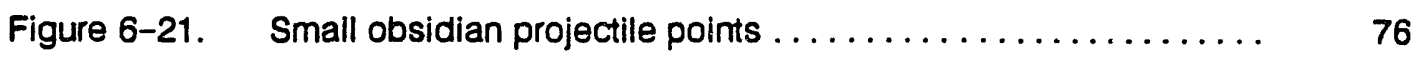

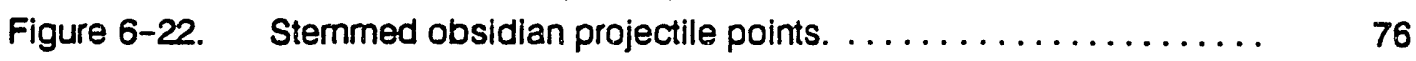

Figure 6-23. Bifurcate-based obsidian projectile points. ............ 77

Figure 6-24. Slab millingstone from $935 \mathrm{~N} 975 \mathrm{E}$ at $26 \mathrm{Ny} 4892 . \ldots \ldots \ldots \ldots . \ldots 79$

Figure 6-25. Scrapers reworked as cores from 26Ny4892. ........... 82

Figure 6-26. Weathered flakes and biface $(264-14)$ reworked as cores
from 26 Ny4892. $\ldots \ldots \ldots \ldots \ldots \ldots \ldots \ldots \ldots \ldots \ldots \ldots \ldots$ 
Figure 6-27. Cores recycled as cores after weathering from 26Ny4892. . . . .

Figure 6-28. Weathered flakes reworked bifacially and Gatecliff point

$(556-1)$ produced on weathered artifact, then weathered again.

Figure 6-29. Core/scrapers produced on weathered flakes from 26Ny4892. . .

Figure 9-1. Summary of obsidian hydration data for projectile points from the Buckboard Mesa Road project.

Figure 9-2. Obisidian hydration measurements of surface debitage from 26 Ny4892 frequency distribution). .............. 106

Figure 9-3. Frequency distribution of reworked antifacts from 26Ny4892. ... 108

Figure 9-4. Summary of all hydration measurements from the Buckboard Mesa Road project.

109

\section{TABLES}

Table 4-1. Metric Attributes of Projectile Points Collected from 26ny4875

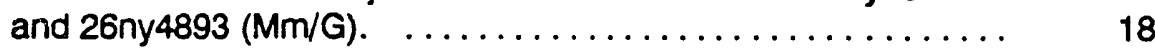

Table 6-1. Subsurface Excavations At 26ny4892. .................

Table 6-2.

Distribution of Surface Artifacts for Each Excavation Unit by

Size Grade Classes.

Table 6-3.

Distribution of Subsurface Artifacts In Level $1(0-5 \mathrm{Cm})$ for

Each Excavation Unit by Size Grade Classes.

Table 6-4.

Size Grade Differences Between Surface and Combined

Surface and Subsurface Assemblages from the

Excavation Units.

Table 6-5.

Cross-tabulation of Obsidian Flake Type Frequencies by Size

Grade from the 26ny4892 Surface Assemblage.

Table 6-6. Flake Type Frequencies and Percentages $(C \mid r)$ by Material Type for the Analyzed Surface Assemblage from 26 ny 4892.

Table 6-7. Material Type Frequencies and Percentages $(R \mid C)$ by Size Grade for Analyzed Surface Assemblage Debitage from 26 ny 4892.

Table 6-8. Size Grade Distributions and Percentages for Obsidian Debitage and Flake Tools from 26 ny 4892.

Table 6-9. Flake Tool Weight Statistics for all Material Types (26ny4892). . .

Tabie 6-13. Material Type Frequencies by Blank Type for Cores from 26 ny4892.

Table 6-14.

Cross Tabulation of Cortex Relicts With Cortex Cover among the Cortical Obsidian Cores from 26ny4892.

Table 6-15.

Distribution of Thinning IndexStatistics by Biface Type for

Table 6-16. Obsidian Bifaces from 26 ny 4892.

Distribution of Thinning Ratio Statistics or Obsidian Cores and Bifaces (by Type) from 26ny 4892.

Table 6-17. One-way Analysis of Variance by Thinning Index among Obsidian Biface Types from $26 n y 4892$.

Table 6-18. Duncan's Multiple-range Test for Means of Thinning Index Values among Obsidian Biface Types from 26 ny 4892. 
Table 6-19. One-way Analysis of Variance by Thinning Ratio among

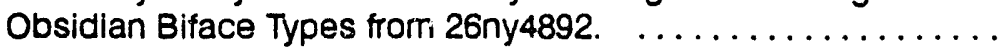

Table 6-20. Duncan's Multiple-range Test for Means of Thinning Ratio Values among Obsidian Biface Types from 26ny4892. ........

Table 6-21. Distribution of Thinning Index Statistics by Incidence of Soft Hammer Percussion among Obsidian Bifaces from $26 n y 4892$.

Table 6-22. Cross-tabulation of Soft Hammer Percussion Evidence among Obsidian Biface Classes At 26 ny 4892.

Cortex Cover Categories among Obsidian Bifaces from

Table 6-23. 26 ny4892.

Frequencies and Parcentages of Material Types among Biface

Table 6-24. Classes At 26ny4892.

Distribution of Thinning Index (Weight/Planview Area) Statistics

Table 6-25. by Material Types among Bifaces from 26ny 4892.

Table 6-26.

Frequencies of Biface Fragment Categories by Biface Classes for all Material Types (26ny4892).

Biface Breakage Frequency Across Material Types from

Table 6-27. 26 ny 4892.

Table 6-28.

Distribution of Thinning Index Statistics by Breakage Groups

Table 6-29. for Bifaces of all Material Types from 26ny 4892.

Table 6-30.

Metric Attributes of Projectile Points from 26 ny 4392 (Mm/G). . . . Descriptions of Millingstones from 26ny4892. .......... 79

Table 6-31.

Frequencies of Point Types from the 26ny4892 Surface Collection.

Table 6-32. Size Grade Distributions of Obsidian Nodules and Obsidian Debitage from the 26ny4892 Surface Collection. ........... 81

Table 6-33. Evidence of Reworking Obsidian Artifacts At $26 n y 4892$.

Table 6-34. Frequencies of Original Artifact forms by Reworked forms (26ny4892).

Table 6-35. Hydration Rims for Reworked Artifacts from 26ny 4892.

Table 6-36.

Distributional Statistics of Hydration Readings from Reworked Artifacts At 26ny4892.

Table 6-37.

Debitage Density Frequencies Per 10-by-10 M Grid Unit from the Main Surface Collection At 26ny4892. .............

Table 6-38. Debitage Density Frequencies and Column Percentages from V arious Site Classes On Pahute and Rainier Mesas.

Cross Tabulation of Artifact Classes by Material Types from the

Table 6-39. 26 ny 4892 Surface Assemblage. ............ 91

Table 6-40. Thinning Indices for Bifaces from 26ny4892. ...........

Table 7-1. Summary of Obsidian Flake Type and Size At 26ny4894. ......

Table 8-1. Summary of Lithic Artifacts from the 18-03 Road Sites. ........

Table 9-4. Sameside Comparisons of Hydration Rims for Reworked 
Table 10-1. Rotated Factor Loadings from Principal Component Analysis of Obsidian Trace Element Data from Yucca Mountain

Projectlle Points and Flakes.

Table 10-2.

Results of Discriminant Function Classification for Yucca

Mountain Obsidian Projectile Points Based On Trace Element

Factor Scores.

Table 10-3. Results of Cluster Analysis for the Obsidian Trace Element Data from the Yucca Mountain Projectile Points. 


\section{ACKNOWLEDGMENTS}

Like most archaeological projects, the successful completion of this report is due to many individuals. While l inherited the responsibility for compiling this report, my involvement came long after the field and lab work had been done. As a result of my ignorance, due credit to some persons may have been overlooked.

The Nevada office of the Department of Energy is responsible of initiating and facilitating the fieldwork. Thanks to those DOE employees who assisted the conduct of this investigation.

Many Desert Research Institute employees aided the completion of this project. Greg Henton and Ron Reno directed the fieldcrews for the Buckboard Mesa Road project. Crew members included Charles Amsden, Nick Chapin, K.C. Dojaquez, Steve Durand, and Cal Nichols. Persons responsible for initial cataloging and analysis included Nancy Botti, Nick Chapin, Kevin Hill, Cari Lockett, and Sue Ann Monteleone. Final sorting and advanced analysis was performed by Laura Hutchins,
Carol Johnson, Laurie Walsh, and myself. Thanks to Laurie Walsh who supplied special effort and expertise in the analysis and report preparation. Janis Klimowicz produced the obsidian hydration data. Discussions with Laurie and Janis often forced me to reevaluate and clarify my analysis and subsequent interpretations. Greg Henton's considerable advice and assistance in the analysis of the artifacts and data was gratefully appreciated. Sue Ann Monteleone rendered the fine artifact line drawings. Carol Johnson cheertully agreed to draft the Buckboard Mesa project and site maps. Carol Bailey was responsible for artifact photography, developing, and printing. Lois Snedden served enthusiastically as the technical editor of this report. Thanks to the superlative efforts of Susan Sawatzky, this report was produced professionally and posthaste. Shirley Garcia served as production and editorial assistant. Finally, Lonnie Pippin provided advice and consulter in the data analysis. Thanks to all of the above individuals for assisting in the completion of this report. 


\section{EXECUTIVE SUMMARY}

In 1986, the Desert. Research Institute (DRI) conducted an archaeological reconnaissance of a new alignment for the Buckboard Mesa Road on the Nevada Test Site for the Department of Energy (DOE). During this reconnaissance, several archaeological sites of $\mathrm{Na}$ tional Register quality were discovered and recorded including a large quarry, site 26Ny4892, and a smaller lithic scatter, site 26Ny4894. The DRI proposed that these sites should be avoided, or investigated if avoidance was not feasible. The DOE chose to investigate rather than to avoid these resources and requested a data recovery plan for these two sites. The DRI developed the data recovery plan to investigate these sites and to inventory the rockshelter sites along the rim of Buckboard Mesa near the new road alignment. The field work for the data recovery plan for 26Ny4892, conducted during the summer of 1987, consisted primarily of controlled surface collection. Analyses of the materials recovered were conducted during the fall and winter of 1989-1990.

Analysis of the debitage at $26 \mathrm{Ny} 4892$ indicates that this area was used primarily as a quarry for relatively small cobbles of obsidian found in the alluvium. Lithic reduction techniques used here are designed for efficiently reducing small pieces of toolstone and are oriented towards producing flake blanks from small cores and bifacially reducing exhausted cores. Projectile point cross references indicate that the area has seen at least casual use for about 10,000 years and more sustained use for the last 3,000 years. Initial obsidian hydration measurements indicate sustained use of the quarry for about the last 3,000 years although the loci of activities appear to change over time.

Based on this study, the DRI recommends that quarrying activities in the area of 26Ny4892 are sufficiently sampled and that additional investigations into that aspect of prehistoric activity in the area are not necessary. This does not apply to other aspects of prehistoric use, however, and DRI recommends that preconstruction surveys continue to identify nonquarrying, prehistoric utilization of the area. The DRI also recognizes that, with the increased traffic on the Buckboard Mesa Road, there is a greater potential for vandalism to sites of National Register-quality located near the road. The DRI recommends that during the orientation briefing the workers at the Test Site be educated about the importance of cultural resources and the need for their protection. 


\section{THE CONTEXT}

\section{Physiography and Geology} Daniel S. Amick

Physiographically, the Buckboard Mesa Road project lies predominantly on a bajada in the headwater area of Fortymile Canyon, a major tributary to the Amargosa River (Figure 2-1). The surveyed area extends southeasterly from a point approximately midway along the south rim of Pahute Mesa toward the Eleana Range. The majority of the road alignment traverses the bajada and fans south of Pahute Mesa until the alignment reaches Buckboard Mesa, a basalt tableland rising above the bajada. The road alignment then skirts along the eastern side of Buckboard Mesa. Fortymile Wash lies on the west side of Buckboard Mesa.

Elevation for the project area ranges from $1890 \mathrm{~m}$ (6200 feet) where the alignment drops off the rim of Pahute Mesa to $1580 \mathrm{~m}$ (5180 feet) where the road parallels an unnamed drainage (herein referred to as Buckboard Mesa Wash) formed between the Pahute Mesa bajada and the talus of Buckboard Mesa. Buckboard Mesa Wash flows basically south, eventually forming a confluence with Fortymile Wash at the southern tip of the mesa. The Buckboard Mesa Road survey ends at its juncture with the 18-03 Road which is about $6 \mathrm{~km}$ north of the southern tip of Buckboard Mesa. The 18-03 Road alignment extends toward the east, away from Buckboard Mesa, across a series of alluvial fan lobes on the bajada roughly perpendicular to the drainage pattern.

In a sense this study is a transect survey of the archaeological record between the Pahute Mesa (Pippin 1986) and the Fortymile Wash areas (Henton and Pippin 1988). However, it is unlikely that this transect is representative of the archaeological record in the entire Fortymile Wash headwater area. In any case it is noteworthy that the most dense remains of prehistoric occupation found during this survey were located on the lower portions of the bajada.
In general the distribution of prehistoric activities probably reflects the local configuration of resources. In addition to the plant and animal communities of this locality, the distribution of water and lithic resources may also condition prehistoric use of the area. Buckboard Mesa itself, a basalt flow which rises over 100 $\mathrm{m}$ above the surrounding alluvial fan topography, served as a focus of some prehistoric activities as well. The abundant petroglyphs and rockshelters along the mesa escarpment attest to significant prehistoric activities in this locality. Seasonal and compositional changes in resource configurations probably altered prehistoric land-use patterns during various prehistoric occupations of the area. Regardless of the exact reason for an apparent concentration of prehistoric activities on these alluvial fans around Buckboard Mesa, the small obsidian cobbles which are found on these fans were evidently exploited as a toolstone source throughout the past 10,000 years.

\section{Geologic History}

The geologic deposits of the region are dominated by Tertiary and Quaternary volcanics. Cornwall (1972:1) summarizes these deposits as follows:

Tertiary volcanic and associated tufaceous clastic rocks cover a large part of the central and northern portions of southern Nye County. A conglomeratic unit comrnonly lies at the base of this section and unconformably overlies older rocks. Pyroclastic tuffs and welded tufts (ash flows) ranging in composition from dacitic to quartz-latitic and rhyolite are most abundant, but lava flows and intrusives of similar composition, and some andesites and basalts, also are common.

A composite section of all the units exceeds 20,000 feet. The vast quantities of volcanic material were probably derived 


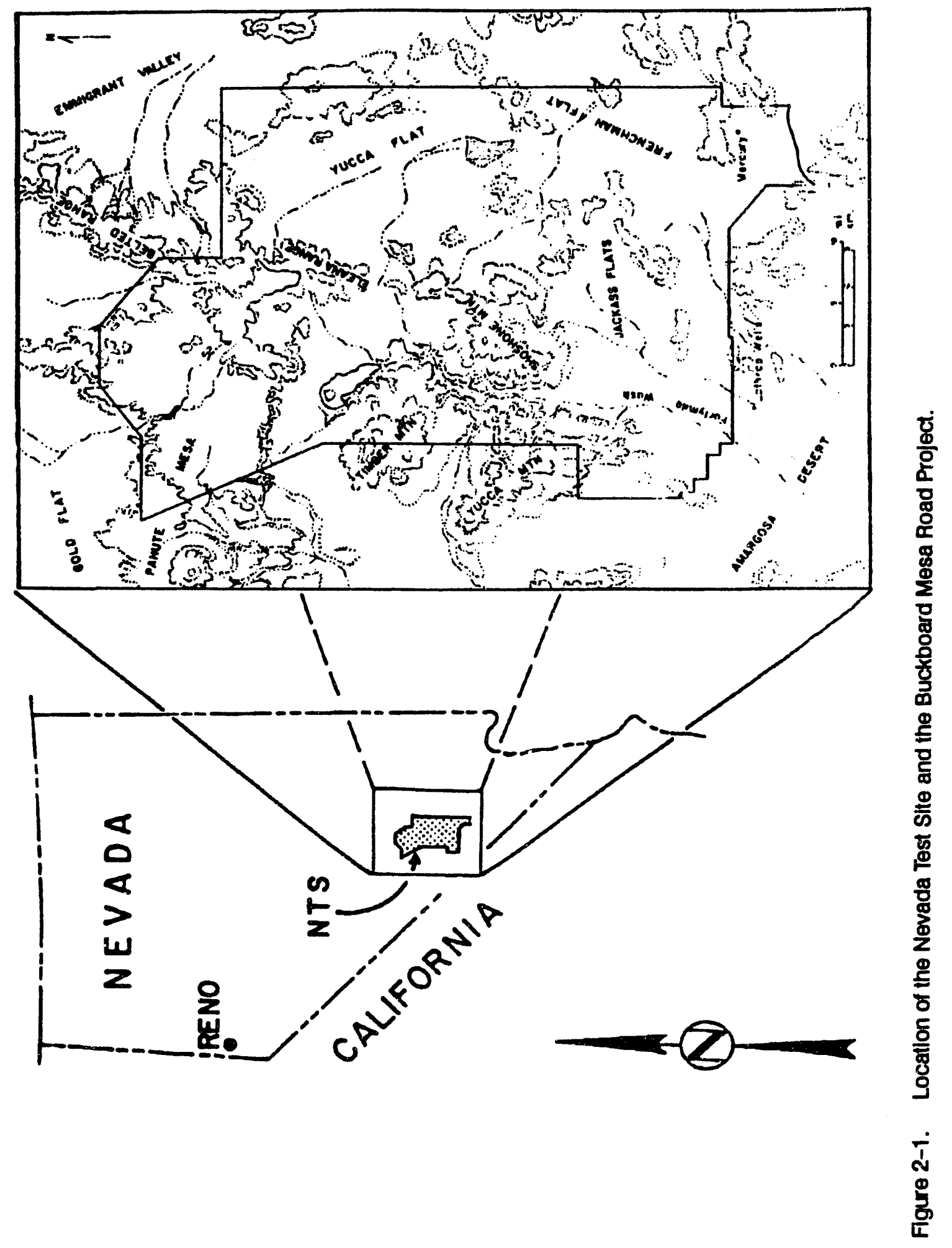


from 9 or 10 centers scattered around the area, $\approx$ least some of which are calderas.

The intermorirane basins in the county are covered by Tertiary and Quaternary alluvial fans and playa lake deposits. In some areas the fans are thin and overlie rock-pediment surfaces. Elsewhere the fans and playa lake deposits are 2,000 or more feet thick.

Quaternary basalt flows and cinder cones, some very young, are present in several lowland areas scattered around the county.

Pahute Mesa rises to the north and the Timber Mountain Caldera rises to the south of the Buckboard Mesa Road. Both of these prominent local landforms are composed of a variety of Tertiary welded tuff formations. Localized intrusives and mineralization zones occur along faults and fissures within the welded tuffs. Stratigraphic cross sections of Buckboard Mesa (Byers and Cummings 1967; Byers et al. 1966; Byers et al. 1976) and radiometric dating of regional volcanic deposits (Marvin et al. 1970) show that development of alluvial and colluvial fans began as early as 11 to 5 million years ago. As Cornwall (1972:27) notes, Pliocene-aged gravel and alluvium underlies the Thirsty Canyon Tuff. The development of alluvial and colluvial fans within the Timber Mountain Caldera Moat are difficult to correlate with bedrock stratigraphy, but they appear to at least predate the Quaternary-aged trachybasalt flows of Buckboard Mesa.

The great antiquity of regional landforms is also notid by Davis (1983:6) who suggests that the modern valleys and ranges within the region are at least 11 million years old and that the basin-fill sediments of volcanic ash are 11 to 5 million years old. He further notes that erosion has removed most of the uppermost parts of the present alluvial fans (Davis 1983:12). As a result, it is expected that remnants of older fan deposits are more likely to be found at the distal ends of fan deposits. Nonetheless, the fan deposits themselves probably represent a complex series of alluvial and colluvial processes which have been operating within the area for at least the past 11 million years.

There are two aspects of this history of fan development that are relevant to the archaeological remains from the Buckboard Mesa proisct. The first issue concerns the origin and distribution of obsidian resources within the fan deposits. Since the exploitation of these obsidian nodules was an important activity around Buckboard Mesa, a better understanding of the resource is necessary for learning about the parameters that form the basis of lithic exploitation. The second issue concerns the apparent stability of the surface upon which the remains were deposited. It is high'y likely that the Buckboard Mesa landforms have not changed substantially during the period of human occupation. This fact is significant for understanding the nature of the archaeological record of the fans surrounding Bucktina s Mesa.

\section{Lithic Resources}

Among the artifact collections from the Buckboard Mesa project, several local lithic resources are significant. The most important of these materials are small nodules of obsidian, cobbles and boulders of purple-brown silicified tuff, and nodules of white vein opal.

\section{Timber Mountain Obsidian}

Lithic reduction in the Buckboard Mesa area focused on exploitation of small obsidian pebbles and cobbles from localized deposits within the alluvial fan gravels in the headwaters of Fortymile Canyon. Archaeological survey of the road alignment as well is survey away from the road alignment to determine site boundaries, show that obsidian deposits within the tan were uniformly small and spatially restricted to particular locales on the lower fan lobes. The uneven distribution of obsidian clasts across the fans may suggest that the obsidian is an ancient alluvial deposit and that the 
fans have been reworked considerably since the obsidians were incorporated as alluvial material. The observation of small obsidian nodules on the surface in the Split Ridge and Falcon Canyon area about $4 \mathrm{~km}$ to the northwest (Pippin 1986:13) and the presence of very small obsidian pebbles on the surface of parts of Pahute Mesa about $8 \mathrm{~km}$ to the north indicates that obsidian deposits may be widespread. However, the occurrence of obsidian outside the fan concentrations tends to be very diffuse. Also, the absence of substantial archaeological evidence of obsidian exploitation at Split Ridge or Pahute Mesa (Pippin 1986) indicates that local obsidian resources outside the fan deposits were not s. ar.ficant.

The patchy distribution of obsidian nodules within the fan deposits is illustrated by the distribution of archaeological sites in the lower portion of the Buckboard Mesa Road. For example, $26 \mathrm{Ny} 4892$ is a large spatially extensive lithic scatter that corresponds to the surface distribution of obsidian nodules. On the other hand, there are a series of small archaeological sites across the 18-03 Road segment. These small discrete lithic scatters correspond to interfluvial knolls on the distal end of the alluvial fan which are separated by eroded shallow fluvial swales. In other words, there is a strong correspondence between the distribution of archaeological materials and obsidian gravels on the fan surfaces. This correspondence in distribution suggests that a significant amount of prehistoric, stone tool manufacturing activities focused directly on the obsidian patches. Although alternative materials for the production of stone tools are found in the alluvial gravels, the obsidian patches served as magnets within at least a portion of prehistoric land use strategies.

Unfortunately, the exact distribution of obsidian gravels within the local alluvial rans is poorly understood. Examination of regional geologic maps (e.g., Byers et al. 1966; Byers et al. 1976; Byers and Cummings 1967; Hinrichs, Krushensky, and Luft 1967) and remote sensing images does not seem to provide much solution to this problem. The geologic maps suggest that the gravels occur throughout the area referred to as the Moat of the Timber Mountain Caldera. While there may be some correspondence between the obsidian distribution and the geologic units mapped as Older Gravel and Tuffaceous Sediments (Tgs), this correspondence is not exact. Byers et al. (1976:3) have described the Tgs Formation as

Gravel and tuffaceous sediments - upper part is caliche-cemented fan gravel with blocks as much as $3 \mathrm{~m} \mathrm{(10} \mathrm{ft)} \mathrm{in} \mathrm{di-}$ ameter grading downward into finer, rounded friable cobble conglomerate. Lower part includes gravel intertonguing with tuffaceous friable sandstone, a few light grey ash-fall pumice-lapilli tuff beds genetically related to Shoshone Mountain rhyolite center, and a few vitric shard tuff beds less than $60 \mathrm{~cm}(2 \mathrm{ft})$ thick.

Although this generalized description does not precisely match the Buckboard Mesa project tan deposits, it provides a regional frame of reference. The variable lithology within the fan deposits, which is evident by the obsidian gravel patches, probably reflects the long and complex geomorphic history of the fans, including extensive reworking throughout the Plio-Pleistocene. Unfortunately, the mapping precision needed to resolve these questions is lacking for the alluvial fans. Mapping of the alluvial fan units, including lithological composition, is needed to understand their historical and genetic relationships. This is the type of geomorphological work which is needed to understand the distribution of important resources (i.e., obsidian) within the fans and the nature of the surface upon which the archaeological record is found.

Tentatively, it is suggested that the obsidian gravels in these fans be called Timber Mountain Obsidian to develop some precision in regional toolstone nomenclature. Admitte- 
dly, the primary source of these obsidian gravels is uncertain, and several sources or volcanic events may be responsible for the obsidian. Although some variation in the appearance of the obsidian is evident, it is always found as subangular or rounded cobbles and pebbles. About $90 \%$ of the obsidian exhibits a nearly opaque, homogeneous black appearance without any inclusions or bubbles which are visible to the naked eye. However, the remaining $10 \%$ of the obsidian includes varieties that are gray and vesicular; black with phenocrysts, ash-fall, or other inclusions; glassy black with green iridescent films; and other types. Whether these varieties represent different sources or not is difficult to determine without characterization studies of trace elements.

An additional complication to understanding the genesis of these obsidians results from the probability that the primary source deposit(s) no longer exist. Nonetheless, the presence of these obsidians in the lower and stable parts of the fans in the Moat of the Timber Mountain Caldera suggests that they may be some of the oldest fan deposits. The stratigraphic position of the Tgs Formation suggests that it may represent the reworked gravels of fan deposits which predate the erosional fans of Pahute Mesa. If the obsidian gravels are not derived from the Pahute Mesa Formations, then Timber Mountain Caldera appears to be a likely candidate for the source as it appears to represent an event of the appropriate age and location. While it may be difficult to ever determine the source(s) of the obsidian gravels with certainty, the temporal and geographic placement of the fan deposits correlates reasonably well with the Timber Mountain volcanic activity and subsequent erosion. Geologic dating (e.g., potassium-argon or fission-track) of the obsidian gravel might provide a means to assess this correlation.

\section{Silicified Tuff}

The massive series of tuffs which comprise the bedrock geology of the Pahute Mesa area serve as the primary source of rhyolitic toolstone. This tuff ranges in size from small pebbles to large boulders and is commonly purple-brown in color and coarse in texture. However, this purple-brown tuff varies considerably in texture and tractability for chippedstone tool production.

Variation in the ability to control the conchoidal fracture of the purple-brown tuff is probably related to its local silicification by hydrothermal alteration. Cornwall (1972:36) refers to these rocks as silicifir:d rhyolitic tuffs and notes that ceramic sili $a$ from the Silicon mine at the northwest end of Yucca Mouritain contains over $99 \%$ silica dioxide by weight. Rocks with this high a proportion of silica dioxide are essentially chert-like in composition. Of course, the isotopic structure of these rocks may vary due to impurities, inclusions, and other factors which affect workability. Chemical composition analyses show that silica dioxide ranges from 53 to $76 \%$ by weight for most of the tuffs of the region (Cornwall 1972:15-26).

The purple-brown tuff is available anywhere near bedrock outcrops around Pahute Miesa. In addition, subangular to rounded clasts of purple-brown tuff are found throughout the Tertiary and Quatemary alluvial gravels. Cobble to boulder size pieces of this material are abundant on the alluvial fan deposits in the Fortymile Canyon drainage. Despite the abundance of purple-brown silicified tuff in the Pahute Mesa and Buckboard Mesa areas, it is rarely used except for the production of large flakes, rough bifaces, and groundstone manos and millingstones. Other toolstone materials tend to be used for the production of projectile points and other more finely flaked implements. In general, the purple-brown silici- 
fied tuff artifacts from the Buckboard Mesa Road survey are the products of rough shaping through the use of hard hammer percussion only.

\section{Vein Opal}

White rhyolitic opal is found throughout the Pahute Mesa area and its alluvial deposits. This material ranges from coarse textured to highly vitreous and is typically milky white or cream in color. Surface exposures of this material on Pahute Mesa suggest that it occurs as silica mineralization along fissures developed in bedrock. The distribution of vein opal is highly localized and difficult to predict because it is determined by both tectonic history and processes of surficial geomorphology. Cornwall (1972:36) notes the occuir ance of silicified and opalized rhyolitic tuff at the northwest end of Yucca Mountain. Residual pebbles and cobbles of white vein opal are commonly found on the surface of Pahute Mesa and in alluvial gravels of the region. Small cobbles of yein opal occur as a minor constituent of the alluvial fan gravels in the Fortymile Wash headwaters.

The mineralogical appearance of white rhyolitic vein opal tuff varies significantly but it frequently exhibits phenocrysts indicative of volcanic origin. Unfortunately, the better grades of this material are often confused with mottled, milky white cherts and chalcedonies. When phenocrysts are present within a specimen, it is possible to distinguish the piece as tuff. However, phenocrysts are not always present, especially in small specimens.

\section{Other Lithic Resources}

The three lithic resources described above are all locally availabie at the lower end of the Buckboard Mesa Road project. In addition, some coarser materials suitable for groundstone artifact manufacture are also available within the fan gravels. While the assemblages studied in this report were predominantly produced by the exploitation of in situs small obsidian gravels, there are some nonlocal lithic matorials which occur in the assemblages as late stage or exhausted artifacts and their by-prorjucts. Cherts, jaspers, and chalcedonies are imported for the most part. Imported obssidians are difficult to distinguish macroscopically from the local gravels, but there if; some evidence that nonlocal obsidian may have been brought in and discarded (see projsctile point discussions for 26Ny4892).

\section{Vegetation}

Vegetation for the project area is almost exclusively an open sagebrush community, both along the rim of Pahute Mesa and along the bajada below (Beatley 1976). Some juniper and, to a lesser extent, pinyon are found along the upper portions of the alignment in sheltered areas below tuff rims. Common plants associated with this sagebush community include Artemesia tridentata, A. nova, Chrysothamnus species, and Ephedra viridis. 


\section{The Cultural Environment}

\section{Lonnie C. Pippin}

Buckboard Mesa lies betwean two areas relatively well known archaeologically Pahute Mesa located to the north and east and Yucca Mountain, including Yucca Wash and Fortymile Canyon, located to the south. Pahute Mesa is a pinyon-juniper-covered questa, where the DOE has conducted numerous underground nuclear tests. Since 1979. archaeological surveys and, more recently, indepth archaeological investigations have been conducted on Pahute Mesa. From these investigations, much has been learned about the nature and periods of occupation of this area, which was known ethnographically as an important source of pine nuts, a staple food for the aboriginal population. Yucca Mountain, on the other hand, has been seiected as a possible site for a high-level nuclear waste repository. Since 1979, this region also has been the subject of archaeological reconnaissances and more in depth investigations. Evidence from this region indicates a long period of utilization by prehistoric peoples, which ev. slved from an early occupation oriented around major drainages such as Yucca Wash and Fortymile Canyon to a late-period occupation. characterized by a more dispersed settlement pattern and by the use of rockshelters and other available natural features. Key to this more dispersed settlement is the increased reliance on small bedrock water catchments, called tinajas, and annual plant resources (Pippin, Clerico, and Reno 1982; Pippin 1984; Henton and Pippin 1988).

\section{Historic Occupants}

When Euroamericans first entered the area now occupied by the Nevada Test Site, they encountered both Southern Paiute and Shoshone. These two Native American groups speak closely related languages belonging to the Utoaztecan language family. Most of what we know concerning the ethnohistory of these aboriginal peoples on and around the Nevada Test Site derives from studies conducted by Julian $\mathrm{H}$. Steward (1938:68, 110-117) in 1935 and 1936 . These people lived in loosely associated family units, wintered at major springs with other families, and dispersed, often in nuclear families, to gather resources in early spring. They continued traveling to gather resources as they became available throughout the summer and early fall. By late fall, the groups migrated to pinyonproducing areas and began collecting one of their primary staple foods, pine nuts. Following the pine nut harvest, the families generally congregated for a fall festival or "fandangu" before returning to their winter villages. Oral history from occupants of the Groom Mine (Reno and Pippin 1986:51), as well as from Steward's (1938) notes, indicates that these Native Americans were still occupying the region around Pahute Mesa in the 1930s.

Steward (1938:93-99, 182-185) reports that between 1875 and 1880 at least three winter camps were located on or adjacent to Pahute Mesa: 1) Wungiakuda, situated two to three miles east of Ammonia Tanks; 2) Mutsi, located on or adjacent to Pahute Mesa northwest of Ammonia Tanks; and 3) Sivahwa, situated a few miles north of Mutsi. The Native Americans occupying these residential bases, although classified as Belted Range Shoshone, were linked through intermarriage and cooperation with the Shoshone living near Beatty in Oasis Valley. In fact, Beatty Shoshone apparently entered the region seasonally to collect wild rye seeds in the vicinity of Ammonia Tanks and pinyon nuts on Pahute Mesa itself (Steward 1938:96). The fall rabbit drive, the only true communal economic activity of these Shoshone, was usually held in Yucca Flat south of Whiterock Spring and was attended by the Belted Range Shoshone, Beatty Shoshone, Kawich Shoshone, and, even occasionally, the Southern Paiute from the Ash Meadows area. This rabbit drive was usually preceded by a fandango held at Wungiakuda, 
or at Beatty when rabbit populations were low in Yucca Flat (Sieward 1938:98).

\section{Prehistoric Lifeways}

The current understanding of southwestern Great Basin prehistory has been summarized by Lyneis (1982b) and Warren and Crabtree (1986), and specialized research topics relevant to the study of this prehistory are sum. marized in the various papers in d'Azevedo (1986). Although earlier reviews (Bergin et al. 1979:129; Coombs, Crabtree, and Warren 1979:62) envisioned stable, unchanging adaptations throughout most of the prehistoric past, the more recent syntheses portray subsistence and settlement patterns in the southern Great Basin as characterized by two general trends through time: 1) an increasing use of upland resources and 2) a low reliance on processed seeds until quite late in time. Changes in group size and mobility also purportedly occurred throughout this period.

Warren (1967) has argued that the earliest artifact assemblages in this region, variously called Paleoindian, Lake Mojave, and/or Western Pluvial Lakes traditions, reflect a widespread generalized hunting adaptation. Bedwell $(1970,1973)$, Hester (1973), and others interpret the same remains to reflect a more specialized adaptation to lacustrine resources around the edges of evaporating pluvial lakes. Davis (1978), on the other hand, surmises a more generalized hunting and collecting economy in which the lakeside sites represent the exploitation of marsh resources only during a portion of the seasonal round. These diverse interpretations result from the fact that most of these early assemblages are limited to surface sites that, besides their common occurrence along shore lines of pluvial lakes and river channels, lack direct information regarding the nature of exploited resources. The few faunal remains associated with the turbated Mount Moriah assemblage at Smith Creek Cave indicate mountain sheep and other artiodactyls were probably the primary game species, but lagomorphs, a fish vertebra, unidentified bird bones, and hair, supposedly from bison and an unidentified Camelid, point to generalized hunting (Bryan 1979). Aside from the few artifacts at Smith Creek Cave, floral remains associated with these early assemblages have not been studied.

Material culture belonging to this Paleoindian or Lake Mojave period has been found at several archaeological sites on Pahute Mesa (Pippin 1986:72), but is more commonly found in the Yucca Mountain area along the major drainages. The occurrence of these Lake Mojave Period projectile points on Yucca Mountain and on Pahute Mesa indicates use of the region during this time period, notably including exploitation of highland resources by these early peoples.

Warren and Crabtree (1986:184-187) view the so-called Pinto or Early Archaic period ( 7000 to 4000 years B.P.) as one of "major cultural adjustments," and some researchers have postulated that environmental conditions in the southwestern Great Basin were so "bad" that the area was essentially abandoned during most of this period (Donnan 1964; Kowta 1969; Susia 1964:31; Tuohy 1974:100-101; Wallace 1962; Warren 1980:35-44). Groups apparently were small and transient, and, due to the small number of known sites and their seemingly temporary nature, Warren and Crabtree (1986:187) think that these populations were "poorly adapted to the desert environment." They profess that unsuccessful attempts to adjust to changing environmental conditions are evidenced by decreasing populations and abandonment of some areas. Lyneis (1982b:177) agrees with previous researchers (e.g., Amsden 1935:33; Rogers 1939:52-53, 65; Susia 1964:17-18; Wallace $1977: 120$ ) that true millingstones are rare or missing in Early Archaic assemblages and uses and that seed exploitation was, therefore, not an important subsistence activity. Wallace (1977:15) suggests that these Early Archaic peoples were game hunters much like the $\mathrm{Pa}$ leoindians that preceded them. Warren and 
Crabtree (1986:187) postulate a "generalized hunting and gathering subsistence system with only the beginnings of a technology for processing hard seeds." The limited faunal remains from the Stahl and AWl sites include artiodactyls, lagomorphs, chuckwalla, and tortoise (i.e., a variety of small and large game), which is consistent with this hypothesis (Harrington 1957; Jenkins, Warren, and Wheeler 1984).

Again, several projectile points from archaeological sites on Pahute Mesa are similar to the Pinto style of point considered diagnostic of the Early Archaic period (Pippin 1986:Table 5), but, in the Yucca Mountain region, most are found along the drainages in a distribution similar to the Great Basin Stemmed types. In contrast, most of the archaeological sites on Pahute Mesa with Pinto types contained a variety of artifacts diagnostic of other periods in prehistory as well. However, a multidimensional scaling analysis of the occurrence of these temporally diagnostic artifacts has revealed that the spatial distribution of Pinto style projectile points is distinct from patterns depicted both by the earlier Paleoindian or Lake Mojave period cultural remains and by material culture assigned to the later Middle and Late Archaic periods. So, while there is evidence of a shift in adaptive strategies during the Early Archaic, we do not yet understand its nature or the meaning of the change in settlement location.

Most researchers (Lyneis 1982b:177; Rogers 1939:61; Wallace 1958:12; Warren and Crabtree 1986:187-189) have perceived a major shift in settlement and subsistence patterns in the southwestern Great Basin during the Middle Archaic or Elko/Gypsum period (4000 to 1500 years B.P.). This perception is based on a radical increase in the number and complexity of known sites falling into this general time period. Lyneis (1982b:177) reconstructs the settlement pattern as characterized by comparatively large "semi-sedentary" communities on the valley floors and a broader use of the landscape, particularly of highland areas. She believes that hunting continued as the major economic pursuit and that the increased frequency of milling implements indicates an expanded reliance on hard seeds. Warren and Crabtree (1986:189) use the occurrence of mortar and pestles at sites near existing mesquite groves to show that mesquite became an "important element in the subsistence system during this period." They interpret the association of split-twig figurines and elaborate rock art with artifact assemblages from these Middle Archaic sites as an expression of an enriched ritual/ceremonial lifestyle and increased socioeconomic ties with outside areas (Warren and Crabtree 1986:189). The beginning of this period is hypothesized to correspond to the beginning of a period of increased moisture and increased contact with the Southwest and with the California coast.

Based on associated projectile point styles, most cultural resources on Pahute Mesa probably do date to Middle Archaic times (Pippin 1986:80-81). In the Yucca Mountain region, Middle Archaic points are more broadly distributed than earlier period points, shifting away from the linear distribution along the drainages. This indicates a major increase in the use of this upland during the Middle Archaic and, as postulated by Lyneis (1982b:177), this increase probably reflects both the expansion of population and the widening of subsistence strategies. Nevertheless, the exact nature of this change in subsistence activities and population density is not yet clear. Based on the number of projectile points, it appears that hunting was still a major economic activity, and most of these diagnostics were recovered from sites interpreted as localities rather than as temporary camps (Pippin 1986:142-158). Nevertheless, sites containing artifacts diagnostic of the Middle Archaic period also contain ample evidence of plant food processing and storage, and, as hypothesized by Thomas (1982) for the Central Great Basin, the exploitation of pinyon nuts 
was probably a major component of subsistence activities by this time.

Lyneis (1982a:177) postulates that the Middle Archaic settlement pattern involving intensively occupied, valley floor camps was replaced by small temporary camps during the Late Archaic or Saratoga Springs period (1500 to 700 years B.P.). Warren and Crabtree (1986:191), however, perceive more continuity in settlement patterns between the Middle and Late Archaic periods, pointing to the large village sites reported around Antelope Valley (Sutton 1981; McGuire, Garfinkel, and Basgall 1981), in Death Valley (Wallace and Taylor 1959), and on the Mojave River (Rector, Swenson, and Wilke 1979). One of the most noticeable changes appears to have been in weaponry, with the bow and arrow replacing the dart and atlatl in frequency. Elston (1986:145) proposes that, in the western Great Basin, this technological change, along with an associated increase in the kinds of plant processing implernents, "accompanied the adoption of a subsistence strategy that entailed an increase both in the diversity of resources used and in the number of ecozones exploited." According to Lyneis (1982b:177), this enlargement in the kinds of resources procured is also shown in the southern Great Basin by sites in woodland covered areas above $6000 \mathrm{ft}$ in elevation.

Multidimensional scaling analysis of the occurrence of temporally diagnostic artifacts at cultural resources on Pahute Mesa tends to support Warren and Crabtree's (1986:191) perception of a continuity in settlement patterns between the Middle and Late Archaic periods (Pippin 1986:86-89). In fact, based on the raw number of projectile points, there appears to be a decrease in the utilization of Pahute Mesa during the Late Archaic rather than the increase hypothesized by Lyneis (1982b:177). However, this change in projectile point frequency most likely reflects a decrease in the emphasis on hunting or a change in hunting strategies more than it reflects changes in population density. In this regard, sites in the Yucca Mountain area follow a similar pattern and show a continued dispersion from the main drainages.

There is considerable evidence both for influence from and for occupation of agricultural societies in the southern Great Basin between about 1500 and 800 years ago (Fowler and Madsen 1986:175-181; Lyneis 1982b:178-179; Warren and Crabtree 1986:191). The majority of these agricultural peoples, coined the Virgin Branch Anasazi, appear to have concentrated their pueblo settlements along the fertile valleys of the Muddy and lower Virgin rivers in southeastern Nevada and in adjacent portions of Utah and Arizona. However, pottery assignable to Fremont agriculturalists also occurs at sites in southern Nevada as far west as Mud Lake and Yucca Mountain (Fowler and Madsen 1986:179-180; Pippin 1984; Self 1980: 127-129). Some of the Virgin Branch Anasazi may have occupied the Las Vegas Valley near Big Springs (Lyneis et al. 1978:142; Rafferty 1984; Warren et al. 1978:20), and there is good evidence that these agriculturalists mined turquoise in the east-central Mojave Desert near Halloran Spring (Leonard and Drover 1980:251-252; Rogers 1929:12-13; Warren $1980: 81-84)$. Most of the evidence for agriculturalists in the southwestern Great Basin, however, is limited to the occurrence of their pottery at sites as far west as the Cronise Basin (Larson 1981; Rogers 1929). Warren and Crabtree (1986:191) and others (Fowler and Madsen 1986:180; Shutler 1961:7; James 1986:114-115; Berry 1974:83-84; Rafferty 1984:30-35) feel these sherds were left by small foraging/hunting parties, but they could also reflect vessels traded to local Saratoga Springs-period hunters and gatherers. The Old Mojave Trail trading route crosses this area, and pottery may have been a traded commodity, along with shells, turquoise, obsidian, and salt (Harrington 1927:238-239; Heizer and Treganza 1944; Hughes and Bennyhoff 1986; Ruby 1970; Pogue 1915:46-51; Morrissey 1968; Shutler 1961:58-66). 
Crude brownware pottery and small sidenotched projectile points have been considered signifiers of the Shoshonean period $(700$ years B.P. to Euroamerican contact) throughout the southern Great Basin (Fowler and Madsen 1986:181-182; Warren and Crabtree 1986:191-192). Responding primarily to a glottochronological hypothesis advanced by Lamb (1958:99), archaeologists (Fowler 1972; Madsen 1975, 1986:213-214; Warren and Crabtree 1986:192) have used these two hallmarks to reflect the expansion of Numic speakers from their southern California homeland to other areas of the Great Basin. Hence, Warren and Crabtree (1986:192) state that the "continuity of the assemblages of the Saratoga Springs and Shoshonean periods in Owens Valley and the Coso Mountains suggests that this Shoshonean assemblage had its origin in that region." Bettinger and Baumhoff (1983) postulate that inferred changes in cultural adaptations outside this core area during the Late Archaic were due to these invading Numic speakers. They believe the Numa were able to displace preceding Saratoga Springs peoples because their high-cost adaptive strategies, oriented around the intensive exploitation of a diversity of seed resources, could sustain larger population densities (Bettinger and Baumhoff 1983).

The Shoshonean period is well represented by cultural resources on Pahute Mesa, and these sites contain evidence that directly pertains to Bettinger and Baumhoff's (1983) postulate. Even more intriguing, however, is the evidence these sites hold regarding changes in the structure of temporary camps during the Shoshonean period and the ways these camps may be reflected in the archaeological record (Pippin 1986:90-103; Henton and Pippin 1989:208). Most Numic sites in the Yucca Mountain area are found at rockshelters located near tinajas or economically important food resources and are noticeably distinct from previous site distributions (Pippin 1984; Henton and Pippin 1988). 


\section{HISTORY OF THE BUCKBOARD MESA REGION}

Alvin R. MClane

The recorded history of the region begins with the trail of the Death Valley Forty Niners through the NTS during 1849. Several splinter groups of this California bound emigrant party passed to the east of the study area. The party of Sheldon Young and possibly the groups of Jayhawkers, Briers, and Haynes passed over Groom Pass and into Yucca Flat before reuniting in Ash Meadows and Death Valley and eventually finding safety at San Francisco, California (Koenig 1984:58-59, 56-66; Long 1950:276 [Sheldon Young's log]; Wheat 1939).

Probably an occasional prospector and other travelers passed through the region shortly after this period. However, the next recorded group into the district was the 1871 Wheeler Survey party. George M. Wheeler was making maps in the west during this time under the auspices of the U.S. Army Corps of Engineers. He and several other assistants had left Halleck Station from the Central Pacific Railroad on the Humboldt River and were surveying the country southward. Wheeler led a contingent into Pahranagat Valley and then traveled west to the Groom Range.

The objective point was a place since called Oasis Valley, known at the time to besensibly to ourwestward, and containing good grass and water. This locality was reached after three days of the most severe marching . . Wheeler (1872:16)

The Wheeler Survey Atlas Sheet Number 66 shows the route passing White Bluff Spr. [White Rock Spring] which continues to Belted Mt. [Tippipah] Spring and on across Fortymile Canyon and south of Timber Mountain to present-day Beatty. Wheeler traveled this route during the heat of July. The road passes along the south end of Buckboard Mesa and this route appears to have been established by then. Wheeler's map labels this road, in error, "First Route across Death Valley."
With the discovery of valuable silver ore at Tonopah in 1900, prospectors explored the surrounding country with renewed vigor. The Beatty Bullfrog Miner for September 16, 1905, describes prospecting activity in Fortymile Canyon. With this activity the U.S. Geological Survey sent parties to the field to make a reconnaissance of the surrounding unmapped desert region during the summer and fall of 1905. Robert H. Chapman was the topographer in charge, and Sydney $\mathrm{H}$. Ball was attached as geologist. They mapped an area covering 8,550 square miles (Chapman 1907). The topography of the study area is depicted on the Kawich 60-minute quadrangle of 1908. Fortymile Canyon and Timber Mountain are delineated on this map, but Buckboard Mesa and Scrugham Peak had not yet been named. A road is shown in the main Fortymile Canyon and extending beyond to Yucca Flat. A trail is shown traversing east/west across Timber Mountain and another along the east side of Buckboard Mesa. Still another trail on the north side of Buckboard Mesa extends from Thirsty Canyon to Ammonia Tanks and be yond to Kawich Valley. The unnamed Scrugham Peak is given an altitude of $6210 \mathrm{ft}$, so it appears that this point was climbed during this early U.S. Geological Survey mapping trip. The water sources in the desert were known by this time since the map shows the names of springs and the bedrock tinajas are labeled "tanks."

Evidence of other historic interest in the vicinity is limited. O.S. Lodwick and wife Mary visited the west side of Buckboard Mesa as shown by an historic inscription and a 1905 date on a rock near Big George Cave. Others began filing mineral location notices on August 13, 1907; the region would later become part of the Wahmonie district (Tonopah Daily Times, March 28, 1928). 
The next recorded trips into the area were searches for archaeological remains. The April 1925 issue of Indian Notes, in the article "Archaeological Researches in Nevada" (pp. 125-127), mentions the "Forty-mile Canyon district" where "some prospectors sent out by Governor Scrugham report ruined buildings, rockshelters showing ancient occupancy, and abundant corrugated pottery in the vicinity of extinct springs about thirty miles from living water." The report continues with "this region is an uninhabited desert, accessible only by means of a pack-train." In the files of the Nevada Historical Society in Reno are found two references to trips made during this period to the vicinity of Big George Cave on the west side of Buckboard Mesa. One source is a February 13,1925, letter by Beatty Justice of the Peace W.B. Gray to Governor Scrugham in reference to two millingstunes and a piece of basketry taken from Big George Cave. The next item is a letter dated May 7, 1925, to Scrugham from pioneer Nevada archaeologist M. R. Harrington. Harrington's summation from his visit to Big George Cave is that it "represents a very primitive culture of Piute type."

During 1928, renewed activity occurred in the Fortymile Canyon. The State of Nevada appropriated $\$ 600$ to study the feasibility of a road along the north side of Buckboard Mesa to facilitate travel between Springdale (8.5 miles north of Beatty) and the Groom Mine (Tonopah Daily Times, January 19, 1928). During this time high-grade silver-gold ore was discovered at Wahmonie about 24 miles southsoutheast from Buckboard Mesa. The townsite of Wahmonie boomed and soon had a post office. Prospectors fanned the hills in search of new ore discoveries. However, the deposits proved to be of limited extent, and Wahmonie died a year later. The post office closed up April 30, 1929 (Harris 1973:55).

Several years later prospectors were still keen on prospecting the Fortymile Canyon District (San Francisco Examiner, May 27, 1933). Roscoe Wright, better known as "Death
Valley Curly," and Jess Clark from Beatty explored the area during early 1940. Today, "DEATH VALLEY CURLEY 1940" can be seen inscribed on a boulder on the west side of Buckboard Mesa. Wright reported on an old Indian town with petroglyphs in Fortymile Canyon and was shocked when he heard that someone had proposed that the area should be used as a practice bombing field (The Mining Press, March 1940). He had become famillar with the district and had located fossil claims in the limestone ridge one mile east of Tippipah Spring. About this time S.M. Wheeler, recently appointed archaeologist with the Nevada State Park Commission, had obtained information about the cultural resources in the Fortymile country. With Roscoe Wright as guide. Wheeler and friends made a trip around Buckboard Mesa from February 27 to March 2, 1940 (Wheeler 1940). Wheeler made another archaeological reconnaissance in the region during late May 1940. During these two trips, he recorded 14 sites within the NTS. Near Buckboard Mesa, Wheeler collected data from the Big George Cave vicinity, the By. Fogle area, Ammonia Tanks, and Sunken Park [Big Burn Valley] (McLane 1988).

In October 1940, a large area in south-central Nevada, principally in Nye County, was withdrawn by the Federal Government and designated the Tonopah Bombing and Gunnery Range. After subsequent niame changes, the withdrawn lands are presently called Nellis Air Force Range. These lands included the Fortymile Canyon country, and the 3,285,511 withdrawn acres effectively eliminated public travel through the region. In 1951, further Federal action placed part of the Nellis Air Force Range under control of the Atomic Energy Commission (now Department of Energy) for operation RANGER, a five-shot program beginning with ABLE on January 27, 1951, a one kiloton nuclear test. Additional land withdrawals and agreements in 1958, 1961, 1964, and 1967 have placed 1,350 square miles within the boundaries of the NTS (Liverman 1977:?-13). 
Archaeological searches were again conducted in the Buckboard Mesa region during 1955 when Richard Shutler, Jr., searching for the western limit of the Pueblo culture in $\mathrm{Ne}$ vada, visited upper Fortymile Canyon. He reported thousands of petroglyphs near Big George Cave and described the artifacts from several rockshelters in the vicinity (Shutler 1961:11). The NTS News for September 14, 1962, illustrated petroglyphs from Fortymile Canyon, and Frederick Worman visited Big George Cave in 1964 (Worman 1964; 1969:25-28).
Before the current research around Buckboard Mesa by DFil, a number of nuclear events were carried out in the vicinity. A nuclear cratering device, code-named DANNY BOY, was detonated on Buckboard Mesa in 1962 for the Department of Defense. Three small atmospheric tests were conducted on the tiats to the east of Buckboard Mesa. The BUGGY experiment, conducted south of Buckboard Mesa in 1968, employed five nuclear devices fired simultaneously to prnduce a simulated canal $77 \mathrm{~m}$ wide, $261 \mathrm{~m}$ long, and $20 \mathrm{~m}$ deep. The small SULKY device with a yield equivalent to 92 tons of TNT, buried $90 \mathrm{ft}$. in basalt, failed to produce a crater (Liverman 1977:2-15). 


\section{PREVIOUS RESEARCH AND PROJECT HISTORY}

Gregory H. Henton

Although significant archaeological sites in the Buckboard Mesa area have been reported since the mid 1920s, there has never been a systematic inventory of these resources. In 1925, M. R. Harrington described Big George Cave to James G. Scrugham, governor of Nevada (Harrington 1925). This shelter, situated at the southern end of Buckboard Mesa, was revisited by S.M. Wheeler in 1940, prior to the withdrawal of this area as part of the Las Vegas Army Air School's bombing and gunnery range (S.M. Wheeler 1940). In the mid 1950s, Big George Cave was again visited, this time by Richard Shutler, Jr. who was looking for rumored pueblo ruins in Fortymile Canyon. Shutler recorded numerous sites during this visit to the upper reaches of Fortymile and Cat Canyons, including additional rockshelters, roasting pits, and rock art panels (chapter 3 by McLane). In 1969, Frederick C.V. Worman published a report on miscellaneous excavations and collections that he had conducted at the Nevada Test Site since the 1950s. Sites he reported on included Big George Cave, the McKinnis site - a large open-air site whose assemblage included a fluted point, numerous Pinto-type points and several rockshelters and rock art sites around Buckboard Mesa and Fortymile and Cat Canyons (Pippin and Zerga 1981; Worman 1969).

Since 1979, the Desert Research Institute has conducted archaeological surveys on the Nevada Test Site. Since most Test Site activities are centered around Pahute Mesa, Yucca Flat, or Yucca Mountain, the DRI has had no reason to conduct reconnaissances in the vicinity of Buckboard Mesa. In June of 1982 , however, three rockshelters were discovered by Ronald Reno of DRI while traveling along the existing Buckboard Mesa Road near the intersection with the 18-03 Road. These highly visible rockshelters were recorded as archaeological site 26 Ny 3166.
In the summer of 1986, the DRI conducted an archaeological reconnaissance of the first two phases of the Buckboard Mesa Road improvement, a new alignment roughly paralleling the existing road alignment from the top of Pahute Mesa in NTS Area 20 down to the intersection of the Buckboard ilesa and the 18-03 roads east of Buckboard Mesa (Figure 4-1). The first phase involved the reconnaissance of $4.76 \mathrm{~km}$ (2.95 miles) of road alignment from the top of the mesa to the base. Eight sites - all isolated artifacts or small lithic scatter - were recorded (Henton 1986a). The second phase of the survey involved $19.74 \mathrm{~km}$ (12.26 miles). Thirteen archaeological sites were found including a large obsidian nodule quarry (26Ny4892), a small lithic scatter (26Ny4886), a temporary camp (25Ny4895), and another small ithic scatter (26Ny4894). Figure 4-1 illustrates the major site locations on the lower portion of the Buckboard Mesa Road and the 18-03 Road. The remaining sites were all small debitage scatters or isolated artifacts. Three of the larger sites -26Ny4892, 26Ny4894, and $26 \mathrm{Ny} 4895$ - were determined eligible for nomination to the National Register of Historic Places, and the report of the survey noted that these sites should be avoided or investigated (Henton 1986b).

For whatever reasons, road construction was implemented prior to any archaeological investigations. While time existed to conduct surface collections at 26Ny4894, portions of $26 \mathrm{Ny} 4892$ and $26 \mathrm{Ny} 4895$ were already destroyed. During the construction of the roadbed, the engineers noted that the deposits in the vicinity of $26 \mathrm{Ny} 4892$ were a good source for road base gravels and they wished to mine the area for this gravel. In response, DRI prepared a recovery plan in March of 1987 for the data at 26Ny4892. In addition to largescale surface collections to be impacted by mining at $26 \mathrm{Ny} 4892$, this data recovery pro- 


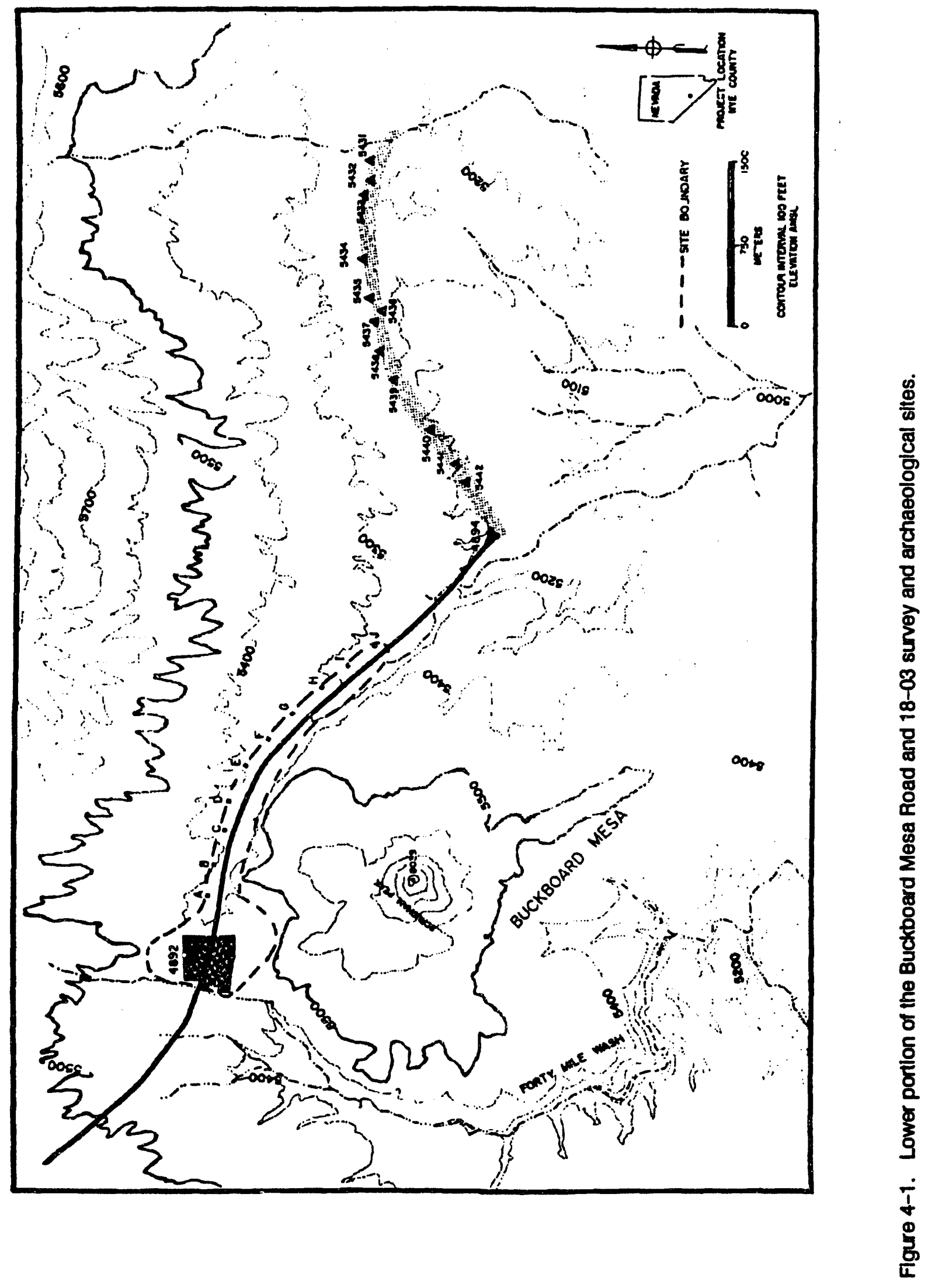


posal suggested sampling other portions of the site and the rim since it has a high potential for rockshelters (Henton and Pippin 1987). Recording the rockshelters along the rim, surface collecting, and subsurface testing were conducted in the summer of 1987 . Nineteen rockshelters or associated sites were found along the rim - site numbers $26 \mathrm{Ny} 3166$ and $26 \mathrm{Ny} 5271$ -5234 .

In September of 1987, DRI inspected the final portion of the road reconstruction, which involved a widening and paving of the 18-03 Road. Twetve archaeological sites (26Ny5431 $-26 N y 5442)$ were discovered along this rightof-way. Because of the linear nature of the survey and the diffuse boundaries if the sites, it was not possible to determine the extent of these sites, and they were interpreted to be loci of quarrying activity associated with the presence of dispersed nodules of obsidian in this geologic formation (Reno 1987). Sample collections and surface scrapes were conducted at several of these sites in March of 1988.

\section{Site Descriptions}

\section{Buckboard Mesá Road, Phase 1}

Eight sites were discovered during the reconnaissance of this portion of the road alignment. All of the sites were located on top of the mesa near the alignment or within the borrow pit which was adjacent iu the east. They were all small and were collected when they were recorded. See Pippin (1986:132-142, Appendix
A:39-42) and Lockett (1988:39-61) for definitions of flake types and biface stages.

Site 26Ny4874 was an artifact locality composed of two artifacts - a vein opal core reduction flake and an obsidian piece of shatter. Site 26Ny4875 was an isolated find of an obsidian Gatecliff projectile point. Table 4-1 presents metric data on the projectile point recovered from 26 Ny4875. Site 26 Ny 4876 was another isolated artifact. sa vein opal tuff stage III biface. Site $26 \mathrm{Ny} 4877$ is also an isolated artifact $-\mathrm{a}$ vein opal decortication flake. Site $26 \mathrm{Ny} 4878$ is a small, diffuse lithic scatter about $45 \mathrm{~m}$ long by $20 \mathrm{~m}$ wide. This site was composed of ten artifacts, six vein opal core reduction flakes, one obsidian and one vein opal biface thinning flake, and an obsidian stage IV biface. Sites $26 \mathrm{Ny} 4879,26 \mathrm{Ny} 4880$, and $26 \mathrm{Ny} 4881$ are isolated artifacts - an obsidian core reduction flake, a vein opal stage III biface, and a vein opal decortication flake, respectively.

\section{Buckboard Mesa Road, Phase 2}

Thirteen sites were recorded along the second phase of the reconnaissance; 10 were relatively small and were collected at the time the sites were recorded. Of the collected sites, 26Ny4883, 4884, 4885, 4889, ano' 4893 are isolated artifacts. They were, respectively, a vein opal core reduction flake, a vein opal biface thinning flake, another vein opal biface thinning flake, an obsidian sore reduction flake, and a vein opal Elko projectile point. Table 4-1 lists the metric attributes for the projectile point from 26Ny4893. Site 26 Ny4886

TABLE 4-1. METRIC ATTRIBUTES OF PROJECTILE POINTS COLLECTED FROM 26NY4875 AND 26NY4893 (MM/G).

\begin{tabular}{lccccccccccc}
\hline Site & Ref & Spc & $L$ & W & NW & BW & MSW & SL & BT & ST & WT \\
\hline 26 Ny4875 & 1 & 1 & - & 27.0 & 10.1 & - & 27.0 & - & 4.0 & 2.9 & 2.7 \\
26 Ny4893 & 1 & 1 & - & 31.0 & 14.9 & 16.7 & 31.0 & 6.6 & 5.1 & 3.5 & 4.9 \\
\hline
\end{tabular}

Key: $L=$ length; $W=$ width; $N W=$ neck width; $B W=$ base width; $M S W=$ maximum shoulder width; $S L=S t e m$ length; BT = blade thickness; $S T=$ stem thickness; WT = weight 
was composed of two small concentrations of debitage about $150 \mathrm{~m}$ apart in a small valley. The first concentration was represented by four obsidian flakes; the second contained nine obsidian flakes, a vein opal flake, and a brown welded tuff flake. Site $26 \mathrm{Ny} 4887$ was a small concentration of obsidian debitage composed of four decortication flakes, six core reduction flakes, and one biface thinning flake. Site 26 Ny 4888 was a small knapping station composed of obsidian and vein opal debitage. Artifacts recovered from this site included an obsidian core and a vein opal core. Obsidian debitage from $26 \mathrm{Ny} 4888$ included one decortication flake, two core reduction flakes, a biface thinning flake, and a piece of shatter. Vein opal debitage from $26 \mathrm{Ny} 4888$ included two decortication flakes, two core reduction flakes, and a piece of shatter. Site $26 \mathrm{Ny} 4890$ was composed of three obsidian core reduction flakes within a $7 \mathrm{~m}^{2}$ area. Site $26 \mathrm{Ny} 4891$ was a locality containing an obsidian core reduction flake and an obsidian stage II biface fragment.

Three sites were not collected at this time 26Ny4892, recorded as a large obsidian quarry; 26Ny4894, recorded as a small, lowdensity lithic scatter; and 26Ny4895, a diffuse scatter of debitage and a millingstone (Figure 4-1). Figure 4-2 is a photograph of the 26Ny4892 area and the Buckboard Mesa roads (old and new). Descriptions of the surface collections and testing at 2 inNy 4892 (Chapter 6 by Amick) and 26Ny4894 (Chapter 7 by Walsh) are included in this report.

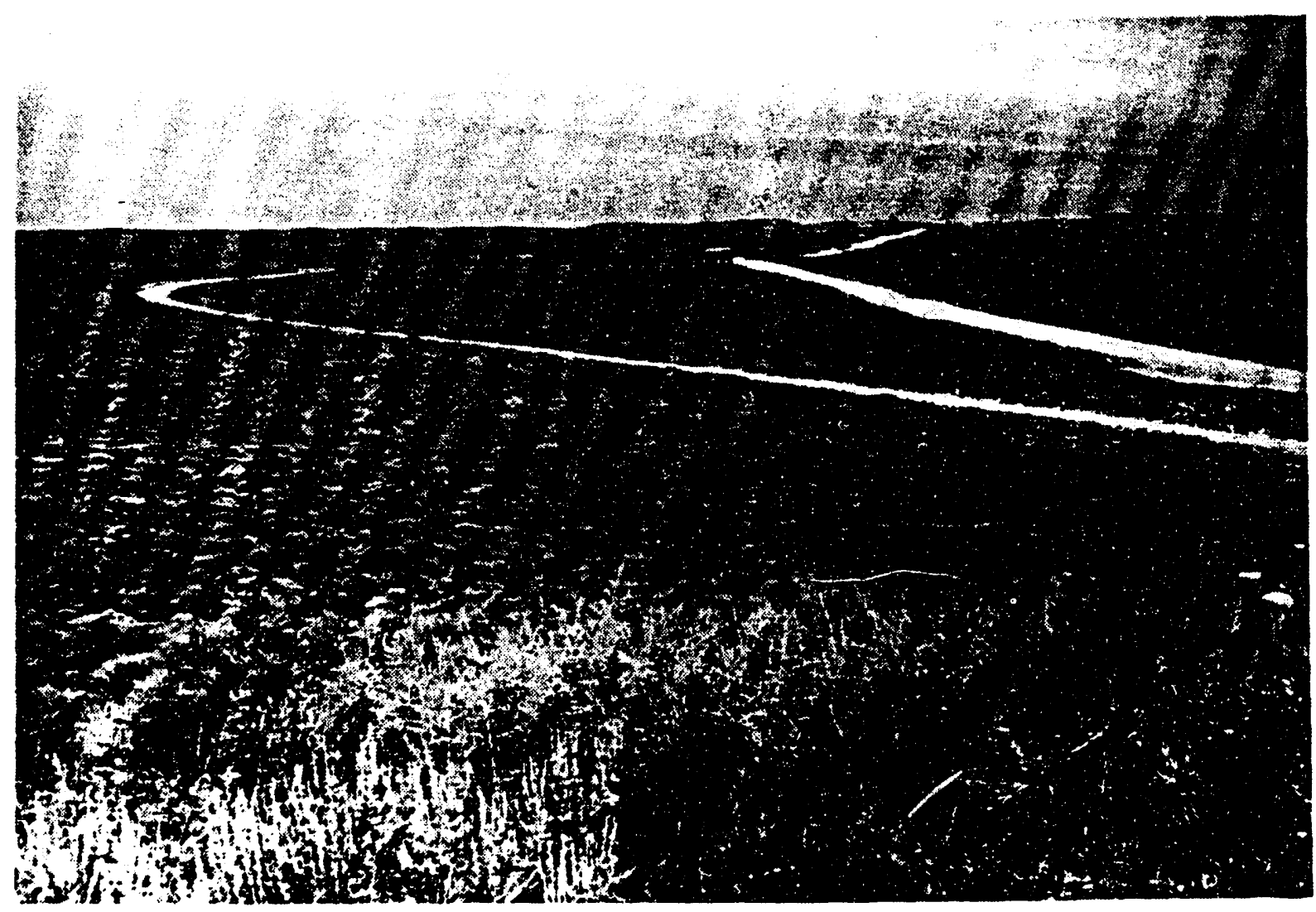

Figure 4-2. Overview of 26 Ny4892 and the Buckboard Mesa roads (old and new) from Buckboard Mesa. 


\section{Buckboard Mesa Rim}

Site 26 Ny3166 was originally recorded in 1987 while archaeologists from DRI were traveling from another project down the old Buckboard Mesa Road. This site is composed of four separate rockshelters situated where the top of the colluvial slope meets the base of the basalt cliff forming the rim of Buckboard Mesa. The distance between the southernmost shelter (division 1) and the northernmost (division 4) is approximately $200 \mathrm{~m}$. The first shelter (division 1) is a relatively large, high shelter; it is $6.5 \mathrm{~m}$ wide, $3.7 \mathrm{~m}$ deep, and $3 \mathrm{~m}$ high. Numerous millingstones and bedrock milling slicks were found in the interior and around the apron of the shelter, and two petroglyph panels are located nearby. One panel is vertical, pecked on the face of the basalt cliff south of the shelter, and it contains two stick figures. The other, found on a boulder in front and to the south of the first, is more horizontal. It is composed of a serpent, or wavy line. Artifacts associated with this shelter include brownware pottery sherds, debitage and at least seven millingstones.

Division 2 is the second shelter. Signs of occupation here are not as intense as in division 1, but still include numerous millingstones, greyware pottery sherds, and debitage. This sinelter is approximately $5.5 \mathrm{~m}$ wide, $4 \mathrm{~m}$ deep, and a maximum of $1.2 \mathrm{~m}$ high. Numerous rocks found in front of the shelter may be the remains of a wall to anchor brush. The third shelter (division 3) is small; it is $1.8 \mathrm{~m}$ wide by $2.7 \mathrm{~m}$ deep by $1 \mathrm{~m}$ high. The little evidence of occupation includes a single obsidian biface thinning flake. The last shelter, division 4 , is more of a cave, the interior being deeper than its width. The face of the shelter is $4 \mathrm{~m}$ wide and maintains this width for about 4 $\mathrm{m}$, where the interior is blocked by recent roof fall. It is estimated that the shelter was approximately $4 \mathrm{~m}$ deeper prior to the fall. The height of the shelter is $1.2 \mathrm{~m}$. Artifacts observed in the shelter included a vein opal core, a basalt millingstone, and four brownware potsherds.
Also observed was a concentration of burnt bone.

Site 26 Ny5217 is a single north-facing rockshelter with a single millingstone and a vein opal biface thinning flake located in the interior. A large rock partially protects the opening of the rockshelter. Like $26 \mathrm{Ny} 3166$ and most of the other rockshelters, it is located at the top of the colluvial slope where it meets the basalt cliff which forms the rim of Buckboard Mesa. This shelter is about $6.5 \mathrm{~m}$ wide and $3 \mathrm{~m}$ deep. Site $26 \mathrm{Ny} 5218$ is another single rockshelter. It is $8 \mathrm{~m}$ wide by $6 \mathrm{~m}$ deep and contains a mano, millingstone, obsidian debitage, and some charcoal.

Site 26 Ny5219 is a single panel of petroglyphs located on a vertical basalt face. Designs include vertical bars, pecking, and a loop figure. The panel is approximately $1 \mathrm{~m}$ wide by $1 \mathrm{~m}$ high. Site $26 \mathrm{Ny} 5220$ is another single panel of petroglyphs, this time lightly scribed in the varnish of a basalt boulder at the top of the colluvial slope. The design is a series of parallel lines running vertically on the boulder face, with an occasional zig-zag line between the parallel lines. The dimen:ions of the panel are less than 1-by-1 m. The boulder is about $1.5-$ by $-1 \mathrm{~m}$ in size.

Site 26 Ny 5221 is another rockshelter. It faces east and is about $8 \mathrm{~m}$ wide by $3.5 \mathrm{~m}$ deep. Artifacts found in the shelter included five millingstone fragments and obsidian debitage, including three decortication flakes, one core reduction flake, and five biface thinning flakes. Some burnt fragments of large mammal bone were also observed in the shelter. Site $26 \mathrm{Ny} 5222$ is another cave, $2 \mathrm{~m}$ wide by $8 \mathrm{~m}$ deep by $1.5 \mathrm{~m}$ high, with a western exposure (Figure 4-3). There is a rock alignment in front of the opening separating the apron from the interior of the cave. The apron in front of the cave appears to have the potential for being over a meter deep. Artifacts observed at the site include six millingstones, an obsidian stage II biface, and obsidian and vein opal debitage. 


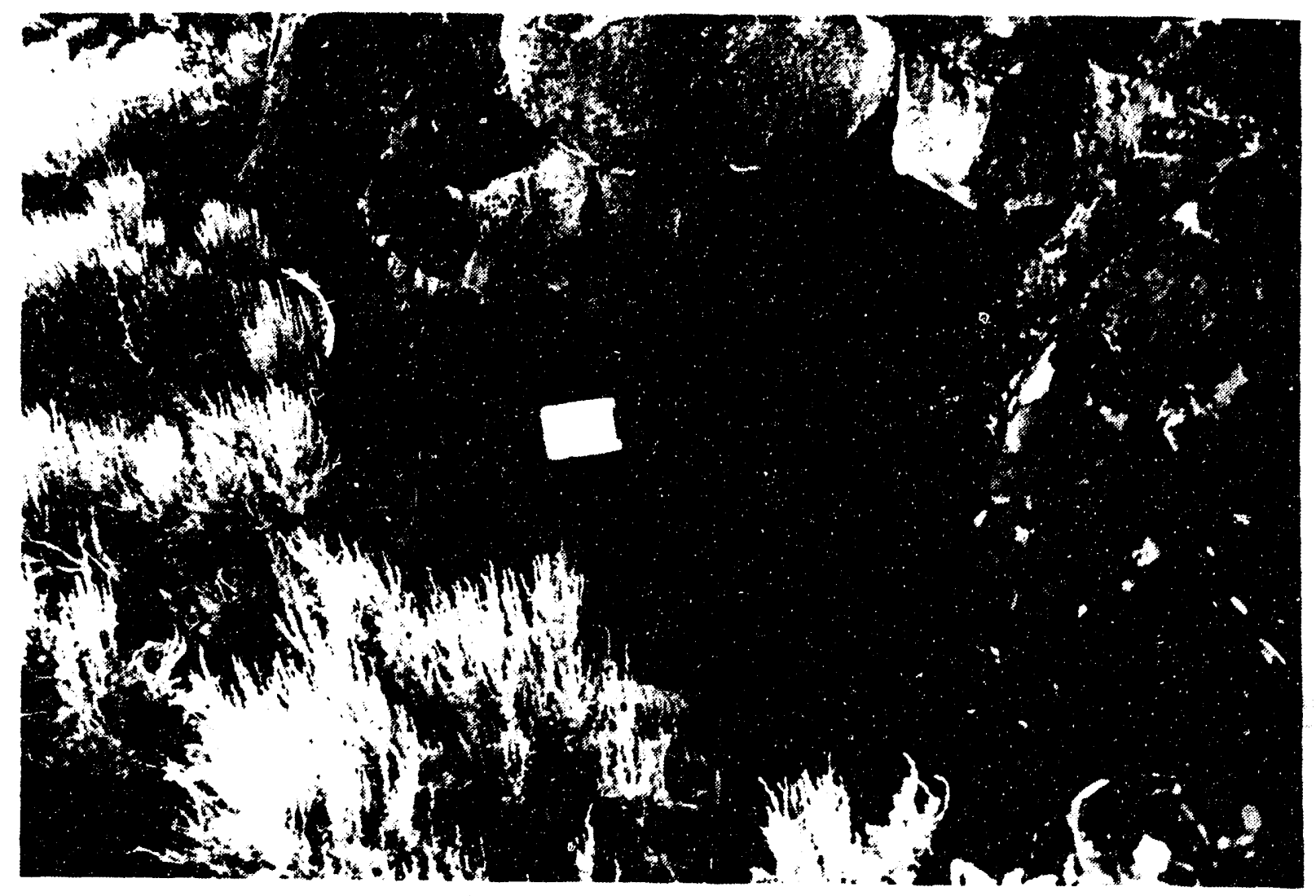

Figure 4-3. Rockshelter 26Ny5222 along Buckboard Mesa rim.

Site 26 Ny5223 is a small scatter of debitage along the base of the cliff and at the top of the colluvial slope. This scatter, which is about 5-by $-5 \mathrm{~m}$ in size, contains ten obsidian biface thinning flakes and an obsidian pressure flake. Site 26 Ny5224 is an east-facing rockshelter which includes three millingstones, a mano, and vein opal debitage. The rockshelter is $6.5 \mathrm{~m}$ wide, $2.8 \mathrm{~m}$ deep, and 1.3 $\mathrm{m}$ high (Figure 4-4). Site $26 \mathrm{Ny} 5225$ is composed of two adjacent rockshelters, both facing north (Figure 4-5). The first shelter is $5 \mathrm{~m}$ wide at the mouth, $2.5 \mathrm{~m}$ deep, and $0.8 \mathrm{~m}$ high. The second is $5 \mathrm{~m}$ wide, $4.8 \mathrm{~m}$ deep, and $0.6 \mathrm{~m}$ high. There is a rock alignment in front of the second shelter. Debitage, consisting of an obsidian core reduction flake and eight obsidian biface thinning flakes, was found in front of the shelters.

Rockshelter $26 \mathrm{Ny} 5226$ is $6.5 \mathrm{~m}$ wide $1.8 \mathrm{~m}$ deep, and $1.8 \mathrm{~m}$ high. Like many of the other shelters, there appears to be a rock alignment around the front of the shelter. Artifacts found here include three obsidian cores, a vein opal utilized flake, three millingstones, and a significant amount of obsidian and vein opal debitage. Obsidian debitage included 16 decortication, 8 core reduction, and 62 biface thinning flakes. Vein opal debitage included 1 decortication flake, 12 biface thinning flakes, and 1 piece of shatter.

Site 26 Ny5227 consists of three petroglyph panels (Figure 4-6) on a north-facing cliff face at a projection on the rim of Buckboard Mesa. The easternmost panel includes two circles around center dots and other symbols, all pecked. The central panel consists of scratched dendritic and grid patterns scratched over pecking. The pecked elements include curves and undulating lines, circles and various lines, and rectangular patterns. The westernmost panel includes bars, dots, lines, and a fence pattern, all pecked. The area of the site is about $1-b y-2 \mathrm{~m}$.

Site 26 Ny 5228 is a locality composed of an obsidian decorication flake and a vein opal 


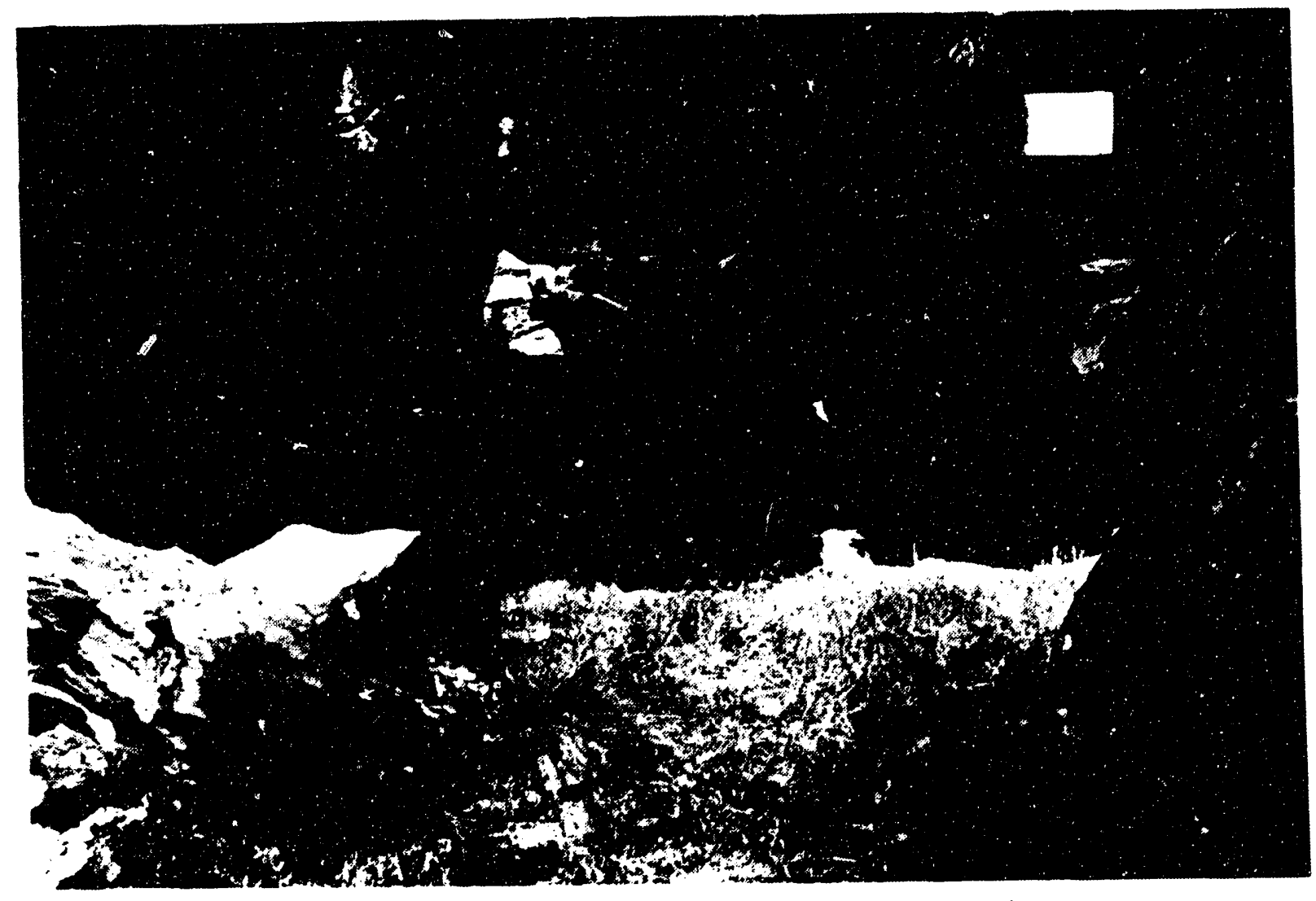

Figure 4-4. Rockshelter 26Ny5224 along Buckboard Mesa rim.

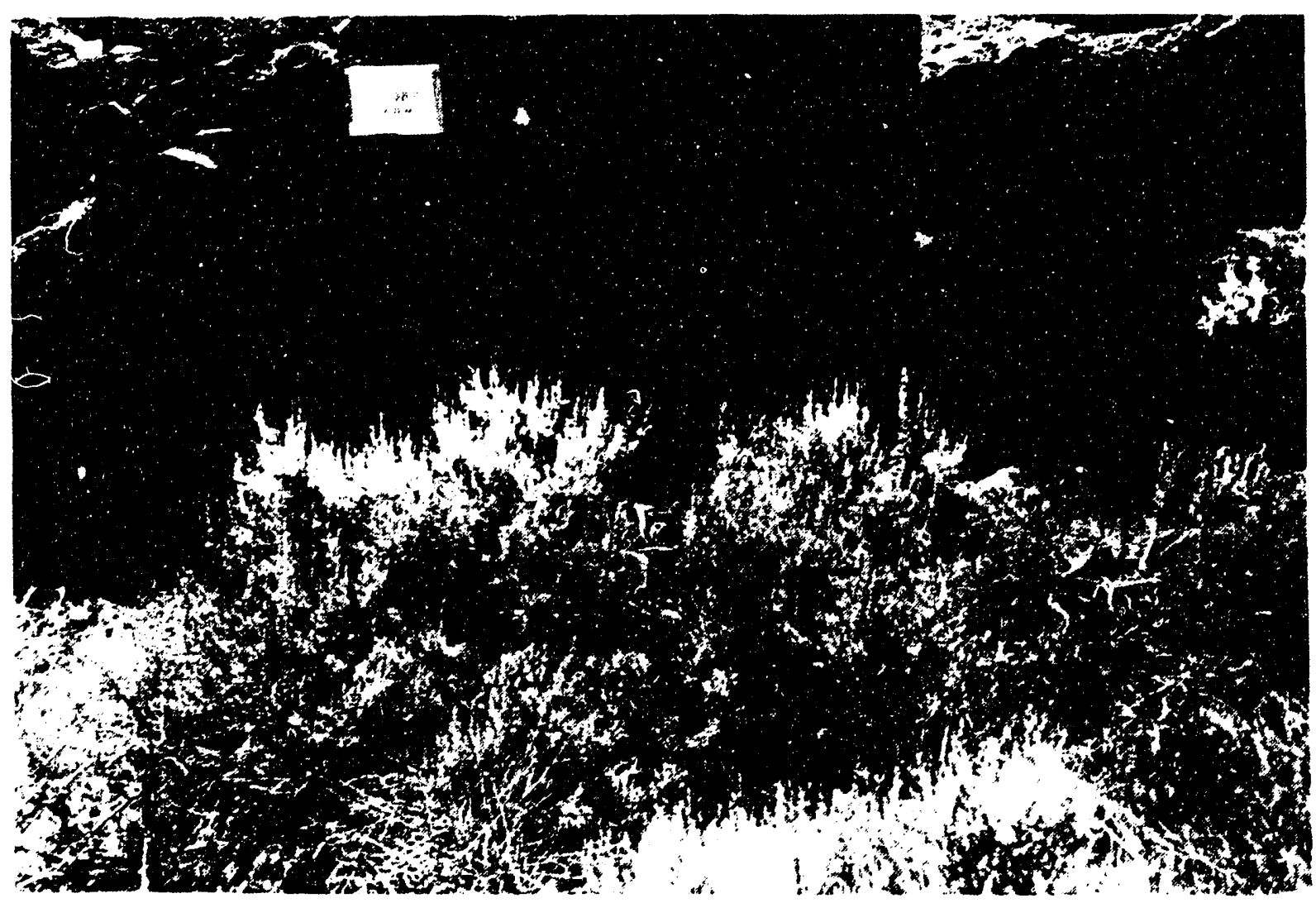

Figure 4-5. Rockshelter 26Ny5225 along Buckboard Mesa rim. 


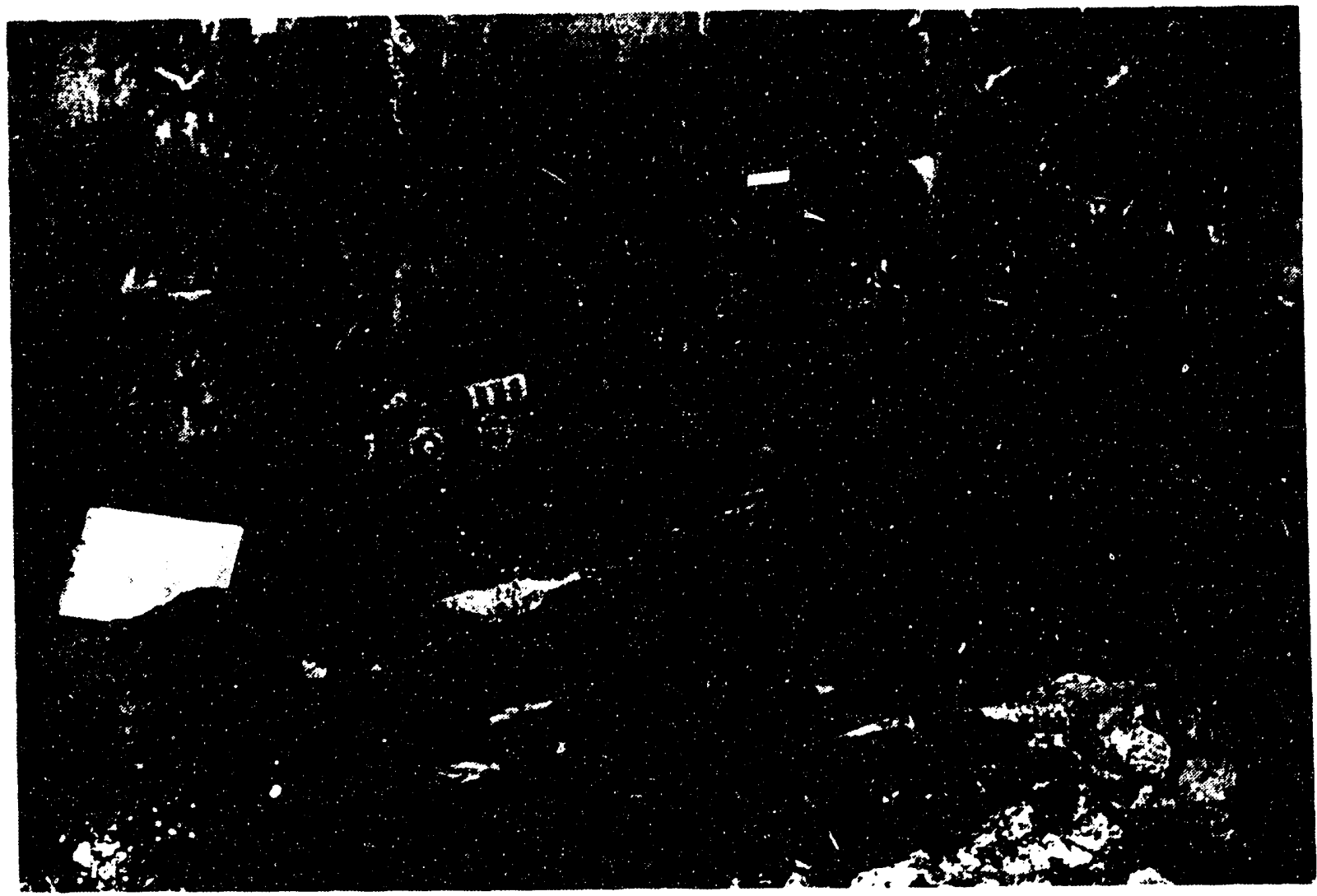

Figure 4-6. Rock art at 26Ny5227 along Buckboard Mesa rim.

core reduction flake. Sites 26 Ny5229 and 26 Ny5230 are individual rockshelters each containing a single millingstone. The size of the $26 \mathrm{Ny} 5229$ is $2.3 \mathrm{~m}$ wide, $2.3 \mathrm{~m}$ deep, and $1.1 \mathrm{~m}$ high (Figure 4-7). Site $26 \mathrm{Ny} 5230$ is 2.5 $\mathrm{m}$ wide by $2 \mathrm{~m}$ deep by $0.9 \mathrm{~m}$ high and has a rock alignment in front of the shelter. Like the previous two, site $26 \mathrm{Ny} 5231$ is also a rockshelter with a single millingstone. However, it is bigger $-5 \mathrm{~m}$ wide by $2.5 \mathrm{~m}$ deep - and contains two wall stubs. One stub divides the interior into two relatively equal halves, and the other enhances the eastern side of the northfacing shelter.

Site 26 Ny5232 is a locality composed of a single obsidian biface thinning flake and an obsidian stage I biface fragment located in a steep drainage in a break in the rimrock of Buckboard Mesa. Site 26 Ny5233 is an eastfacing rockshelter with a relatively deep cavern located in the back. One millingstone was observed in the interior of the shelter, and five more were observed around the apron. One millingstone appeared to be covered with pigment on the working surface. A small amount of debitage, predominantly obsidian, and an obsidian stage IV biface were also observed. The shelter may have had a semicircular cache built of rocks south of the shelter. The size of the shelter is $3.5 \mathrm{~m}$ wide by $3.5 \mathrm{~m}$ deep. Site 26 Ny5234 is another rockshelter with a milling slick on a large boulder in front. This shelter is $7 \mathrm{~m}$ wide by $5 \mathrm{~m}$ deep. Aside from the milling slick, artifacts found here were limited to another millingstone in the interior and an obsidian biface thinning flake.

\section{8-03 Road}

All twelve of the sites recorded along the 18-03 road were predominantly surface scatters of obsidian debitage (Figure 2-1). Description of these assemblages is provided in Chauter 8. By and large, they are located on interfluves of a large south-facing bajada originating from Pahute Mesa. Site 26Ny5431, the easternmost site in the survey, is a diffuse scatter of obsidian and vein opal chert debitage. 


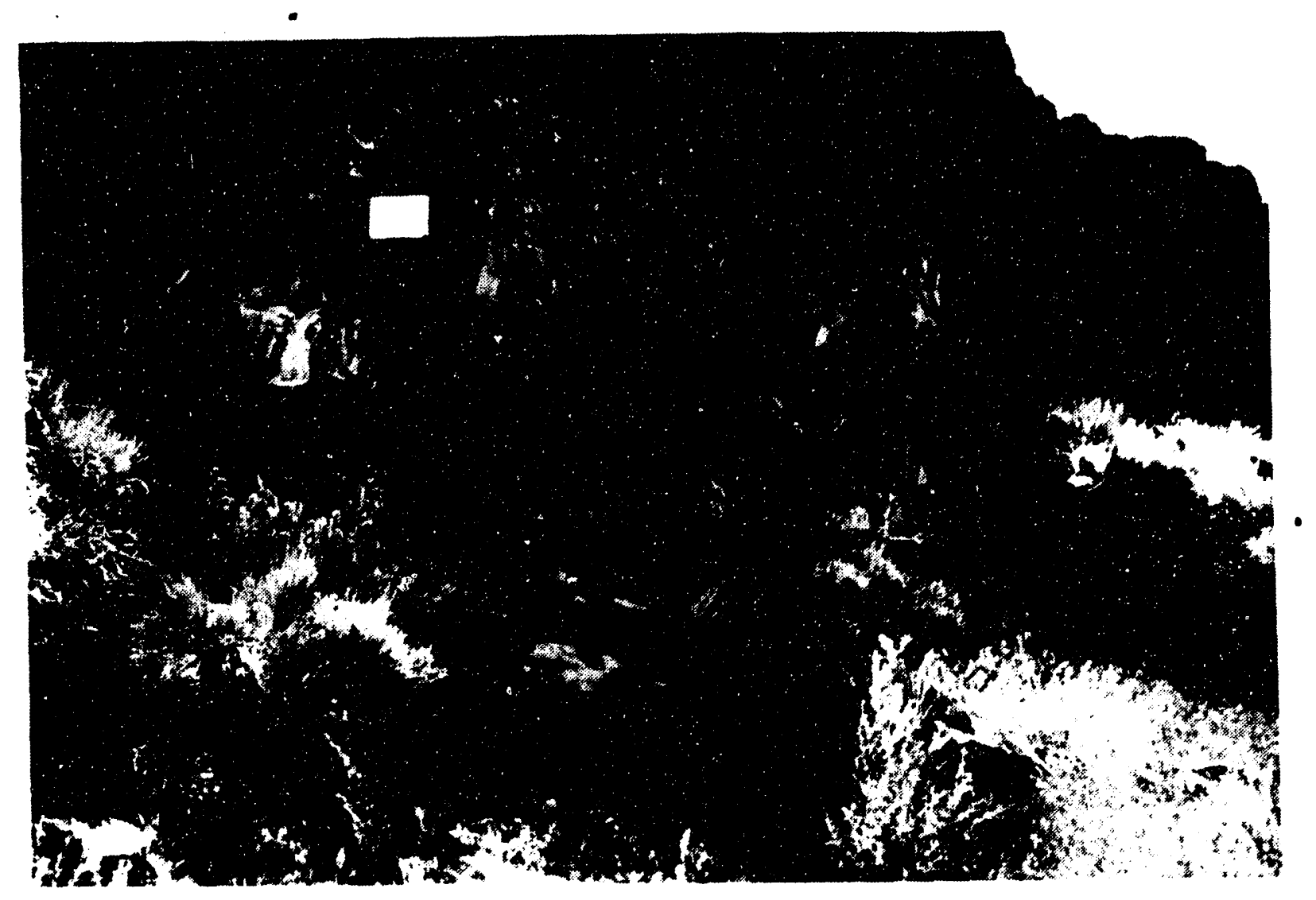

Figure 4-7. Rockshelter 26Ny5229 along Buckboard Mesa rim.

Artifacts at the site include a resharpened Lake Mojave projectile point with a heavily ground base. Site 26 Ny5432 is composed of an obsidian stage I biface and a decortication flake. This site was collected when it was recorded. Site $26 \mathrm{Ny} 5433$ is a knapping station with two vein opal decortication flakes, two vein opal core reduction flakes, an obsidian decortication flake, and an obsidian core reduction flake. This site was also collected at the time it was recorded. Site 26 Ny5434 is a diffuse quarry of obsidian gravels containing decortication and core reduction flakes, several cores, and a stage I biface. Site 26 Ny5435 is another diffuse quarry which includes obsidian decortication, core reduction flakes, and several cores. A knapping station composed of decortication and core reduction flakes of grey flow-banded welded tuff flakes is also present at this location. Site $26 \mathrm{Ny} 5436$ consists of two large, obsidian, core reduction flakes. This site was collected when it was recorded. Sites 26Ny5437-26Ny5442 are diffuse quarry areas consisting of obsidian decortication flakes, core reduction flakes, shatter, and cores.

During the evaluation of these sites along the 18-03 Road, Reno (1987:1) interpreted them as part of a large intermittent quarry where prehistoric peoples extracted nodulesized obsidian, widely dispersed in the alluvial deposits. 


\section{RESEARCH DESIGNS AND METHODS}

Lonnie C. Pippin and Gregory H. Henton

We have previously proposed eleven broad and general research questions designed to guide archaeological investigations on Pahute Mesa so as to provide data pertinent to addressing information concerns of the $\mathrm{Ne}$ vada Division of Historic Preservation and Archaeology and the scientific community (Pippin and Henton 1988). To realize the goals of the proposed investigations, methods were required which would provide the necessary information and were based on the nature of the resources present. Since most of the cultural resources to be investigated appeared to be surface scatters of artifacts and features, the primary method of data recovery was controlled surface collection. The surface collection data were supplemented by subsurface scrapes and test excavations. Test excavations were conducted in artifact concentrations to look for buried cultural material in geologically depositional environments. Subsurface scrapes were conducted to investigate the effects of turbation on surface artifacts.

\section{Purpose}

Various environmental legislation, particula:ly the National Historic Preservation Act (NHPA) and the National Environmental Policy Act (NEPA), charges the DOE with the responsibility of identifying and preserving significant cultural resources on properties which they administer. Significance for most archaeological sites is defined in 36 CFR 60.4 as having "integrity of location, design, setting, materials, workmanship, feeling and association and . . . that have yielded, or may be likely to yield, information important in prehistory or history." To help identify whether an archaeological site is significant in terms of this definition, the $\mathrm{Ne}$ vada Division of Historic Preservation and Archaeology (NDHPA) has identified seven research domains which it considers important to the study of Nevada prehistory. These seven domains are studies of settlement pat- terns, subsistence systems, past environments and geochronology, trade and exchange, ideology and belief systems, directional change through the Archaic, and lithic analysis (Lyneis 1982a).

\section{Research Questions}

The types of information obtained from archaeological sites depends primarily on the data at the archaeological site and the questions asked during the investigations of the site. One cannot be certain what information a given archaeological site may conceal. Based on previous knowledge of the area's archaeology, however, a strategy for investigations can be established beforehand to maximize the potential to recover data of interest. Pippin (1986:39-54; Pippin and Henton 1988:9-10) has reviewed the seven research domains presented in the state historic plan (Lyneis 1982a) specifically with regard to the archaeological record on Pahute Mesa and has developed eleven research questions which may be addressed by this record. The eleven questions, discussed in detail elsewhere (Pippin and Henton 1988:10-22), are listed below.

1) What are the relationships between Anasazi cultural remains on Pahute and Rainier mesas and those of the nonhorticultural hunters and gatherers who traditionally utilized this environment?

2) What is the relationship between past fluctuations in the environment of Pahute and Rainier mesas and prehistoric patterns of settlement and subsistence?

3) What are the history and processes of past residential mobility and demography on Pahute and Rainier mesas?

4) What are the sources of raw materials used in artifacts and features found at cultural resources on Pahute and Rainier mesas? 
5) What strategies of subsistence resource utilization are represented in the archaeological record of Pahute and Rainier mesas, how has this resource utilization affected settlement patterns, and how have these subsistence and settlement strategies or their relationship changed through time?

6) What is the history and magnitude of fluctuations in the environment of Pahute and Rainier mesas during the last 18,000 years?

7) What behavioral information (e.g., methods of tool manufacture, changes in lithic technology, economy of resource use, and nature of associated activities) is represented by lithic debitage at lithic scatters on Pahute and Rainier mesas?

8) What are the processes and chronology of sediment deposition on Pahute and Rainier mesas, and how may natural geologic and biotic processes have affected the nature of the archaeological record there?

9) How are ethnohistoric sites on Pahute and Rainier mesas represented in the archaeological record, and how may this information be used in modeling more ancient settlements and activities?

10) What are the spatial relationships of cultural remains on Pahute and Rainier mesas to each other and to available natural resources?

11) How old are the cultural remains in question?

Using these questions as guidelines for evaluating the archaeological sites found on the Buckboard Mesa Road project, these sites were found to be significant and potentially eligible for nomination to the National Register of Historic Places (Henton 1986b:3-4). The NDHPA concurred with these findings, and the DOE was then responsible for preserving the scientific information potential of the sites. In situ preservation is preferred since current archaeological philosophy stresses preservation. This is also often the cheapest alternative for the land-managing agency. However, in situ preservation is not required when the scientific information at an archaeological site can be recovered and preserved through archaeological investigations. The DOE chose to meet its obligation by investigating the majority of the archaeological sites in preference to in situ preservation.

\section{Methods}

To understand both the intersite and intrasite variability necessary to answer the questions posed above required a broad range of investigations at Buckboard Mesa. Appropriate methods for data recovery were dictated by two factors: the research questions being asked and the cultural material present at the site. Data recovery techniques were required for identifying the internal variability and associations necessary for intrasite analysis and for characterizing the site and its cultural components for intersite and environmental comparisons.

The data recovery plan proposed for the Buckboard Mesa sites involved a large scale surface collection of the majority of the area to be directly impacted at two sites - 26Ny 4892 and all of $26 \mathrm{Ny} 4894$. This was supplemented by sample collections outside the main concentrations of artifacts, subsurface scrapes, and test excavations at areas with the potential for buried cultural materials. The four specific techniques employed during the investigations were mapping. controlled surface collection, subsurface scrapes, and excavations.

\section{Mapping}

Many of the research questions depend on knowledge of cultural resources relationships or environmental features. Therefore, detailed mapping was an important element in the data recovery and is one of the primary methods of preserving these relationships. All sites inves- 
tigated were mapped planimetrically, with important topographical features mapped to scale. These maps included the grid system used for provenience, surface collection, excavation, and surface scrape units. These maps were compiled concurrently with the surface collections at the Buckboard Mesa sites. The collection grid was staked in the field, and detail was added to the map as the collection proceeded. While most of the area was mapped in this fashion, radial measurements which were later converted to grid coordinates were used on occasion to include relevant features located beyond the grid system. These measurements were made with a Brunton compass on a tripod and a $30 \mathrm{~m}$ fiberglass tape.

\section{Surface Collection}

Controlled surface collection was one of the principal data recovery techniques used at the Buckboard Mesa sites. Its purpose was to efficiently recover a substantial percentage of the cultural material on the ground surface while maintaining meaningful units of horizontal provenience. Surface collection was implemented by imposing a metric grid over the area of impacts and collecting the cultural material observed in each grid square. The units were usually $10-$ by $-10 \mathrm{~m}$ in size for general collection, but areas could be collected in smaller units, if warranted. Each unit was designated by the grid coordinate of its northeast corner.

As the sites were separated by a considerable distance, separate grid systems were used for each of the collected sites. The grids themselves were oriented north-south, and the datum for each grid system was given an arbitrary designation: $1000 \mathrm{~N} 1000 \mathrm{E}$ in the case of $26 \mathrm{Ny} 4892$ and $100 \mathrm{~N} \mathrm{100E}$ in the case of 26Ny4894. The grid was established by locating a Brunton compass on the site datum and setting reference points along the four cardinal directions. These lines were extended to encompass the area of expected impacts - in the case of $26 \mathrm{Ny} 4892$, about $600 \mathrm{~m}$ north-south by $600 \mathrm{~m}$ east-west. Since $26 \mathrm{Ny} 4894$ was much smaller, a smaller grid was needed, approximately $60-$ by $-30 \mathrm{~m}$ in size. Because the collection area at $26 \mathrm{Ny} 4892$ was so large, additional reference lines were needed. Flagged lathes were placed at $150 \mathrm{~m}$ intervals along these baselines. Secondary east-west axes were established at intervals of $150 \mathrm{~m}$ along the main north-south axis. Like the baselines, these secondary axes were flagged at $150 \mathrm{~m}$ intervals, and lathes were placed at $30-m$ intervals between the flags. The final step before surface collection was to place pin flags at 10-m intervals between the flags and lathes as temporary guides for gridding the site.

Once the baselines and secondary axes had been established, the majority of the area of impact was collected using a mobile rope grid capable of delineating nine 10-by-10 m collection units (a $30-$ by $-30 \mathrm{~m}$ area) (Figure $5-1)$. The flags on the baselines and secondary axes divided the site into approximately 16 collection areas 150 -by-150 $\mathrm{m}$ in size. Several of these collection areas were located along the edges of the site. so only portions of the $150-$ by $-150 \mathrm{~m}$ area were collected. Each of these areas was collected in a systematic fashion. The general collection of one of the 150-by-150 m collection areas usually involved the following steps:

1) Four ropes, calibrated to $30 \mathrm{~m}$ in length and marked every $10 \mathrm{~m}$, were laid on the ground perpendicular to one of the axes and in one corner of the collection area. This created nine 10-by-10 m collection units in a 3-by-3 $\mathrm{m}$ arrangement (Figure 5-2A).

2) These units were collected by archaeologists walking at closely spaced intervals inspecting the ground surface.

3) After completing the collection of the existing nine units, the ropes were pulled and a new set of units created. The direction of the units was maintained by sight- 


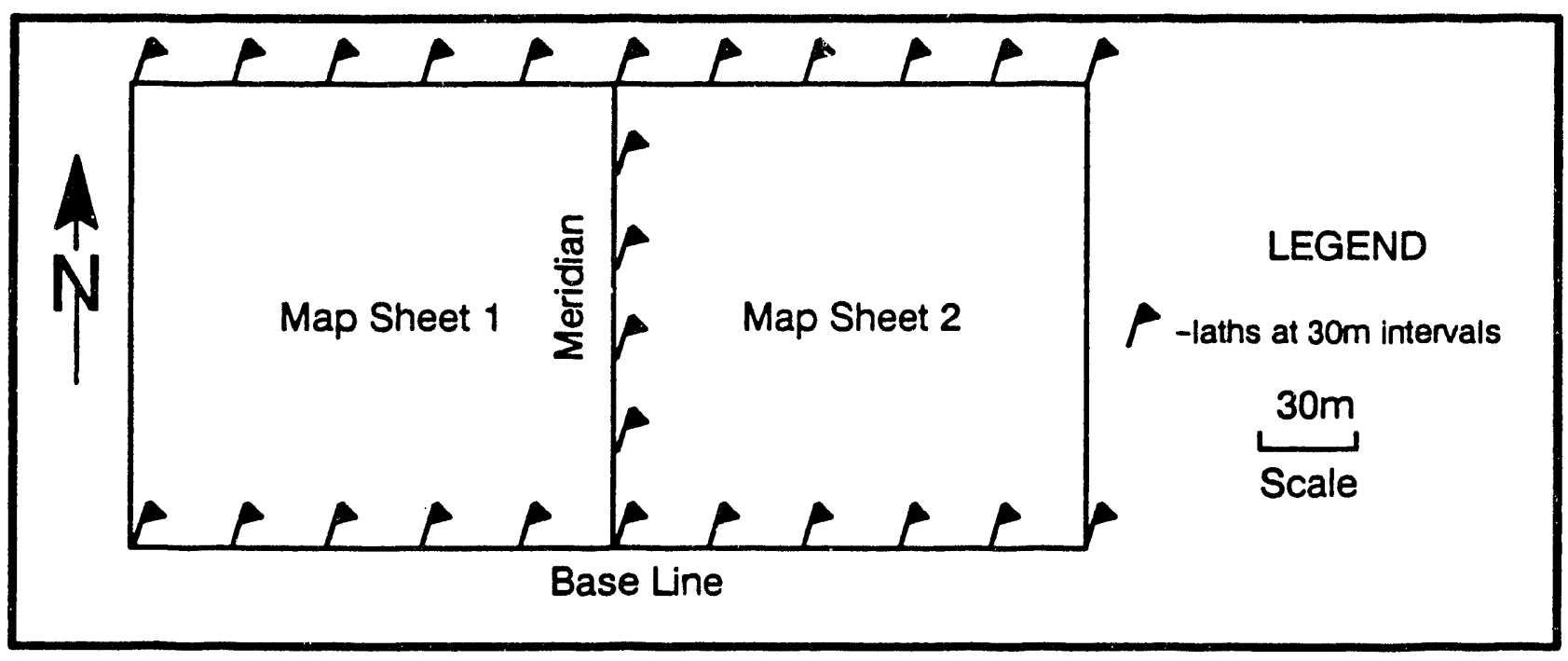

Figure 5-1. Collection Grid Baseline and Meridians

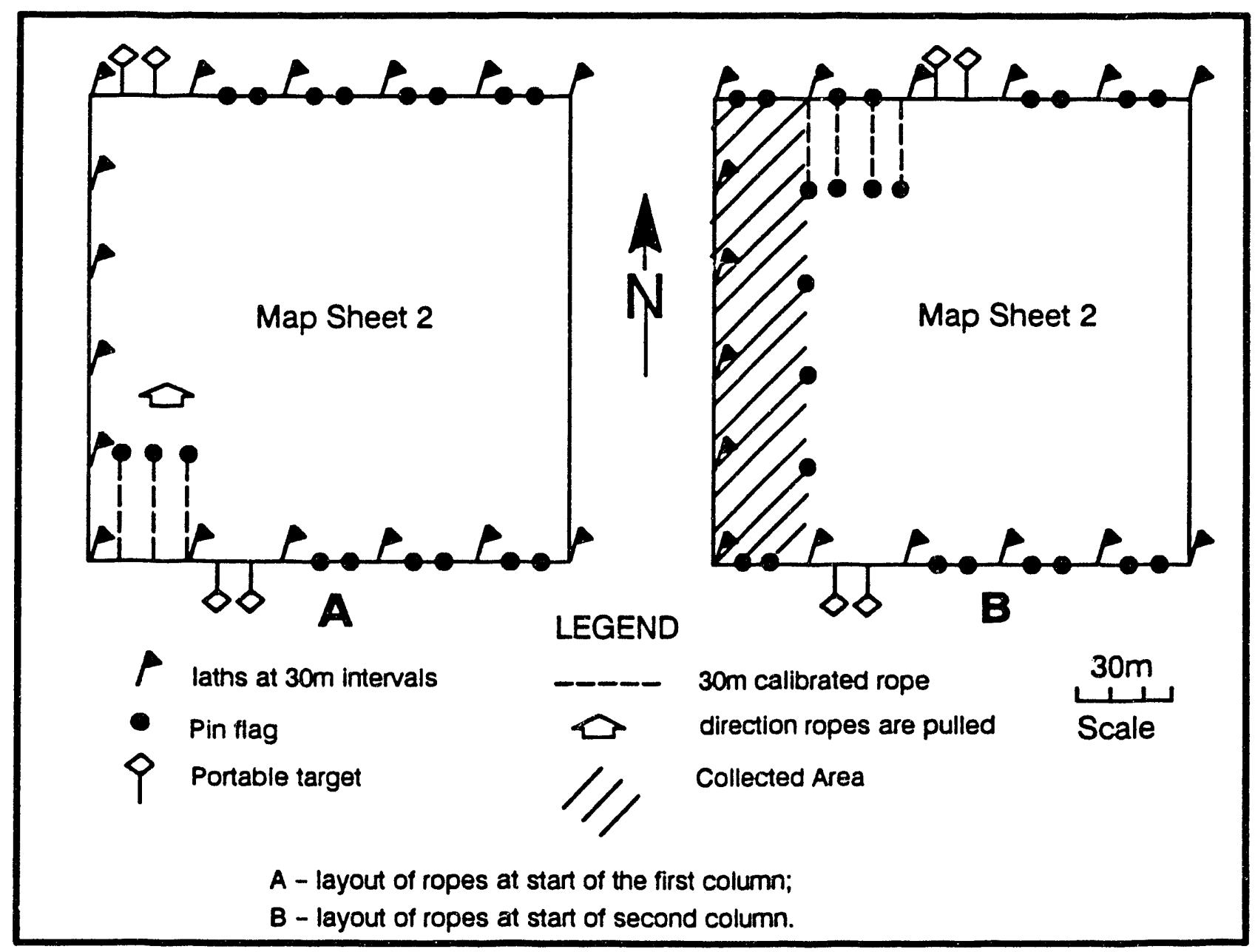

Figure 5-2. Rope Grid Collection System 
ing with a Brunton compass. These new units were collected as described above.

4) After five pulls of the ropes, or $150 \mathrm{~m}$, the far boundary of the collection area was reached. After the final units in this row were collected, the ropes were coiled, and the crew moved to the next row (Figure 5-2B). The ropes were laid out, and this row collected in the opposite direction as before.

5) The 150-by-150 $\mathrm{m}$ collection area was finished when five rows had been collected.

6) Each area which would be impacted was collected in this manner.

Archaeologists inspected each collecion unit by walking back and forth o pre the unit, spacing their transects no wider than $2 \mathrm{~m}$ apart. All nondiagnostic artifacts collected as the walk-through proceeded were placed in plastic bags. If a collection unit contained artifacts, it was assigned a reference number. This number was recorded on a tag which was placed in the bag, in a log identifying the provenience of the collection unit and the reference number, and on the site map. Diagnostic artifacts (e.g., projectile points, sherds, and groundstone) received a "point" provenience, that is, a location to the nearest meter. These artifacts received a separate reference number plus provenience calculated from the 10-by-10 m collection unit datum (northeast corner) and were bagged separately.

Part of the goal of the investigations was to assess the portions of $26 \mathrm{Ny} 4892$ which had been disturbed by the road building, but were not going to be mined for gravels. Sample collection grids, $30 \mathrm{~m}$ on a side and thus forming nine 10-by-10 m collection units, were collected at intervals along the north side of the new road alignment. The distance between each sample collection area was 0.2 miles (approximately $160 \mathrm{~m}$ ), and the samples were taken $30 \mathrm{~m}$ from the edge of the road.
In addition to the collection of cultural materials, raw materials available at the site were sampled. The method for this sample was to collect all of the obsidian toolstone in a 10-by-10 m collection square and bag it separately from the cultural material. The toolstone sample units were spaced at $100 \mathrm{~m}$ intervals in the main collection area, so 10 -by-10 collection units with even hundreds designations (e.g., Unit 100N 200E) were sampled for toolstone. Material samples were also collected from the sample collection grids described above. In this case, toolstone was collected from the center $10-b y-10 \mathrm{~m}$ unit in each of the sample grids.

\section{Subsurface Scrapes}

Subsurface scrapes provide a more detailed assessment of how well the visual collection represents the cultural material actually present and help document the effects of turbation. Subsurface scrapes were performed in areas which appeared to have the potential for limited buried deposits or at locations of substantial accumulations of debitage. The methods for conducting these scrapes were as follows: 1) a rectilinear area was delimited (usually a 2-by-2 or 3-by-3 $\mathrm{m}$ area), 2) the unit was visually collected and the artifacts bagged and recorded, 3) the top 3 to $5 \mathrm{~cm}$ of soil was removed using a square shovel and screened through 1/4-inch mesh screen, and 4) the artifacts from the screen were bagged and assigned a reference number.

\section{Excavations}

Test pits are 1-by-1 $\mathrm{m}$ excavation units usually oriented north-south. Test pits are numbered consecutively by project, when one 1-by-1 unit is dug adjacent to another, each unit receives the same numeric designation, but a distinct letter designation.

These units are dug in natural stratigraphic levels, if possible, or in arbitrary levels, if natural strata are too thick or are undetectable. Natural strata are generally divided into arbitrary $10 \mathrm{~cm}$ levels unless reason exists to use a 
different width. Sterile fill over irregular bedrock surfaces for example, is often removed in wider than $10 \mathrm{~cm}$ levels. Levels are the basic: unit of observation and are numbered consecutively from the top level to the bottom. Cultural material on the surface is recorded as level 0 ; the first level excavated is level 1.

After each level is screened, a record is cornpleted which cuntains site reference number, level reference numbers, location of the unit, depth of the level, cultural material recovered, soil matrix removed, and natural stratumobservable, soil being excavated. The surface of the unit is defined as stratum $A$, the first excavated stratum is stratum $B$. Strata and levels may coincide, but often differences exist because breaks in strata may be hard to detect during excavation or a stratum may be thick enough to be divided into several levels. All levels of each unit receive a unique reference number, even if culturally sterile and usually all artifacts from the level are logged with this number.

Soil is removed from the unit by shoveling it directly into a screen. If the distance to the screen is too far or the unit too deep, it may be moved to the screen in buckets. The soil is screened through 1/4-inch mesh screen and then inspected for artifacts. Generally, all artifacts recovered from a level of a unit are logged together, but carbon, delicate artifacts, or other samples may be stored separately. These are given a separate reference number.

During the excavation, larger objects, rocks, features, or artifacts are left in situ, at least until the completion of the level. Depending on their nature or the nature of the excavation, they may be removed or left while excavations continue. Such items will be sketched in the level record, and if warranted, they will bophotographed. Excavations generally continue until the soil become culturally sterile, bedrock is encountered, or evidence indicates that any cultural material present is due to secondary deposition.

Documentation for each unit includes the level record, discussed above, and a synopsis of the completed unit. If any special samples were taken, a separate record was completed for each sample, and any reference numbers issued were recorded in a reference log. Two adjacent sidewalls were sketched, and the unit was photographed. 


\section{SITE 26Ny4892: AN OBSIDIAN NODULE QUARRY}

\section{Daniel S. Amick}

\section{Archaeological Surface History}

An important aspect of the geologic history of the Fortymile Wash headwater fans concerns the nature of the surface history for the past 15,000 years or so. Geologic summaries of the area have suggested that older fan surfaces have remained essentially stable during this time. The co-occurrence of temporally sensitive artifacts (e.g., projectile points), which have been cross-dated from about 10,000 to 100 years ago on the same surface in this survey, suggests that the archaeological record from these collections represents a complex palimpsest (an unstratified layering of debris left from successive occupations).

\section{Stratigraphy and Surface Size Sorting Effects}

An examination of test pit stratigraphy shows that vertical separation of the archaeological deposits is probably a postdepositional effect. At 26Ny4892, eight test pits or surface scrapes were excavated (Figure 6-1). Provenience descriptions for these units are listed in Table 6-1.

Figure 6-2 illustrates the north wall profile for Unit 1. The top $3 \mathrm{~cm}$ of this stratigraphic sequence is composed of desert pavement and eolian dust. Underlying the pavement is a vesicular A soil horizon. This $2-3 \mathrm{~cm}$ thick soil is

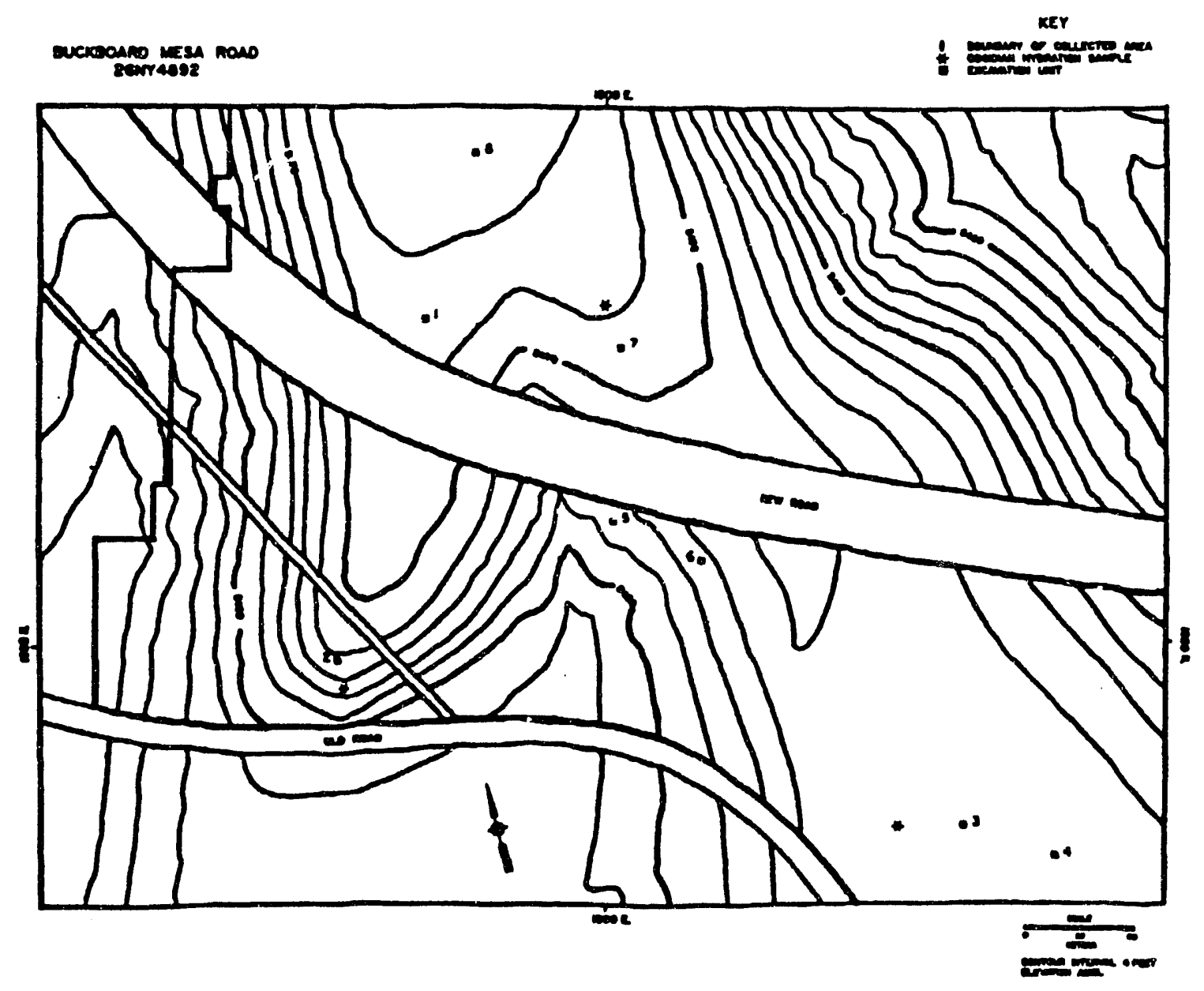

Figure 6-1. Main surface collection area at Site 26 Ny4892. 
characterized by weakly developed polygonal structure and vesicular bubbles. The presencs of this soil development berieath the desert pavement suggests some stability in the current land surface. Underlying the vesicular A horizon soil is a calcareous $B$ horizon which is found from about 6 to $13 \mathrm{~cm}$ below the ground surface. Some alluvial gravels were found in the $B$ horizon. Beneath the $B$ horizon is a calcareous $C$ horizon which also includes a few alluvial gravels. The $\mathrm{C}$ horizon ranges from about 19 to $24 \mathrm{~cm}$ below the surface. The bottom of the excavation unit rests upon a calcareous bedrock formed within the alluvial deposit. Excavation in Unit 5 produced a similar stratigraphic sequence. This general type of sequence is not uncommon for Mojave desert pavement settings (e.g., McFadden, Wells, and Jercinovic 1987) although different parent materials may alter the specific appearance of the profile.

TABLE 6-1. SUBSURFACE EACAVATIONS AT 26 NY4892.

\begin{tabular}{lccllr}
\hline Unit & Grid & Coordinate & Unit Type & Unit Size & Final Depth \\
\hline 1 & $1084.0 \mathrm{~N}$ & $906.0 \mathrm{E}$ & Excavation & $1 \times 1 \mathrm{~m}$ & $24 \mathrm{~cm} \mathrm{b.s.}$ \\
2 & $990.0 \mathrm{~N}$ & $858.0 \mathrm{E}$ & Scrape & $2 \times 2 \mathrm{~m}$ & $5 \mathrm{~cm}$ b.s. \\
3 & $897.0 \mathrm{~N}$ & $1194.0 \mathrm{E}$ & Scrape & $2 \times 2 \mathrm{~m}$ & $3 \mathrm{~cm}$ b.s. \\
4 & $880.0 \mathrm{~N}$ & $1242.0 \mathrm{E}$ & Scrape & $2 \times 2 \mathrm{~m}$ & $3 \mathrm{~cm}$ b.s. \\
5 & $1072.5 \mathrm{~N}$ & $1007.5 \mathrm{E}$ & Excavation & $1 \times 1 \mathrm{~m}$ & $24 \mathrm{~cm} \mathrm{b.s.}$ \\
6 & $1052.5 \mathrm{~N}$ & $1053.5 \mathrm{E}$ & Scrape & $2 \times 2 \mathrm{~m}$ & $3 \mathrm{~cm} \mathrm{b.s.}$ \\
7 & $1166.0 \mathrm{~N}$ & $1013.0 \mathrm{E}$ & Scrape & $3 \times 3 \mathrm{~m}$ & $2 \mathrm{~cm}$ b.s. \\
8 & $1277.0 \mathrm{~N}$ & $932.0 \mathrm{E}$ & Scrape & $2 \times 3 \mathrm{~m}$ & $3 \mathrm{~cm}$ b.s. \\
\hline
\end{tabular}

Key: b.s. = below surface

\section{BUCKBOARD MESA ROAD \\ ZENY 4892 \\ UNIT I \\ PROFILE OF NORTH WALL}

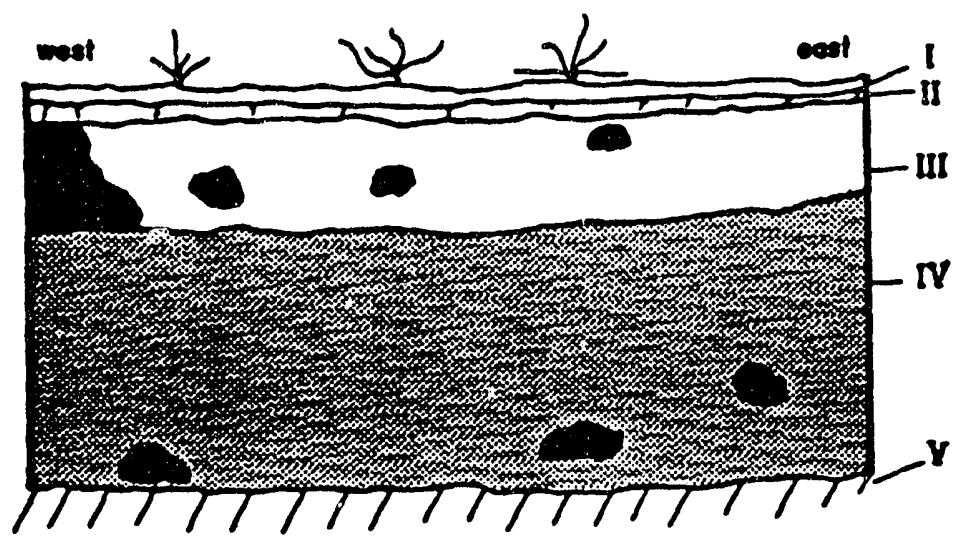

KEY

I DESERT PAVEMENT and EOLIAN DUST

II A HORIZON-VESICULAR SOIL

III B HORIZON

IV C HORIZON

$\checkmark$ CALICHE BEDRROCK

- ROCK

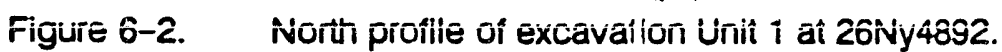

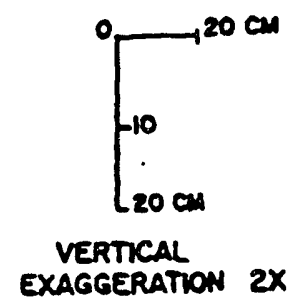


Although excavation Units 1 and 5 extended $24 \mathrm{~cm}$ below the ground surface, no artifacts were found more than $5 \mathrm{~cm}$ below the ground surface in these excavations. The excavation units produced a total of 3 bifaces, 3 cores, 2 flake tools, and 390 pieces of debitage; $256(64 \%)$ of these artifacts were found on the surface while the remaining 142 (36\%) were recovered within the top $5 \mathrm{~cm}$ of the excavations. Table 6-2 lists the frequency of surface artifacts and Table 6-3 lists the frequency of subsurface artifacts recovered from each excavation unit. The vertical distribution of artifacts within these test excavations suggests that cultural materials are restricted to the desert pavement and eolian dust unit which overlies the vesicular A horizon soil. However, a few artifacts may be displaced downward into the soil due to movement through the vertical cracks. The absence of artifacts from below the vesicular A horizon suggests that this surface has been stable throughout the period of human occupation at 26Ny4892. Based upon obsidian hydration rims and cross-rating of temporally sensitive artifacts (Chapter 9 by Klimowicz), this period seems to encompass at least the past 10,000 years.

Figure 6-3 compares the size grade distributions of surface and subsurface artifacts. The bar chart of relative frequencies shows that more large-sized artifacts (grade 3 ) are found on the surface. Subsurface artifacts tend to be smaller as illustrated by the predominance of material in grade 4 . The smaller

TABLE 6-2. DISTRIBUTION OF SURFACE ARTIFACTS FOR EACH EXCAVATION UNIT BY SIZE GRADE CLASSES.

\begin{tabular}{|c|c|c|c|c|c|c|c|c|c|c|}
\hline \multirow{2}{*}{$\begin{array}{l}\text { Size } \\
\text { Grade }\end{array}$} & \multicolumn{8}{|c|}{ Unit Number } & \multicolumn{2}{|c|}{ Totals } \\
\hline & 1 & 2 & 3 & 4 & 5 & 6 & 7 & 8 & $\#$ & $\%$ \\
\hline 1 & 0 & 0 & 0 & 0 & 0 & 0 & 0 & 0 & 0 & \\
\hline 2 & 0 & 6 & 1 & 1 & 0 & 0 & 0 & 0 & 8 & (03) \\
\hline 3 & 1 & 28 & 16 & 3 & 0 & 0 & 23 & 11 & 82 & (32) \\
\hline 4 & 0 & 21 & 23 & 4 & 0 & 5 & 69 & 4 & 126 & (49) \\
\hline 5 & 0 & 10 & 9 & 1 & 0 & 1 & 19 & 0 & 40 & (16) \\
\hline Totals & 1 & 65 & 49 & 9 & 0 & 6 & 111 & 15 & 256 & \\
\hline
\end{tabular}

TABLE 6-3. DISTRIBUTION OF SUBSURFACE ARTIFACTS IN LEVEL 1 (0-5 Cañ) FOR EACH EXCAVATION UNIT BY SIZE GRADE CLASSES.

\begin{tabular}{|c|c|c|c|c|c|c|c|c|c|c|}
\hline \multirow{2}{*}{$\begin{array}{l}\text { Size } \\
\text { Grade }\end{array}$} & \multicolumn{8}{|c|}{ Unit Number } & \multicolumn{2}{|c|}{ Totals } \\
\hline & 1 & 2 & 3 & 4 & 5 & 6 & 7 & 8 & $\#$ & $\%$ \\
\hline 1 & 0 & 0 & 0 & 0 & 0 & 0 & 0 & 0 & 0 & \\
\hline 2 & 0 & 1 & 0 & 0 & 0 & 0 & 0 & 0 & 1 & (01) \\
\hline 3 & 0 & 9 & 1 & 0 & 0 & 1 & 8 & 0 & 19 & (13) \\
\hline 4 & 0 & 11 & 7 & 6 & 0 & 3 & 88 & 0 & 115 & (81) \\
\hline 5 & 0 & 0 & 0 & 0 & 0 & 0 & 7 & 0 & 7 & (05) \\
\hline Totals & 0 & 21 & 8 & 6 & 0 & 4 & 103 & 0 & 142 & \\
\hline
\end{tabular}




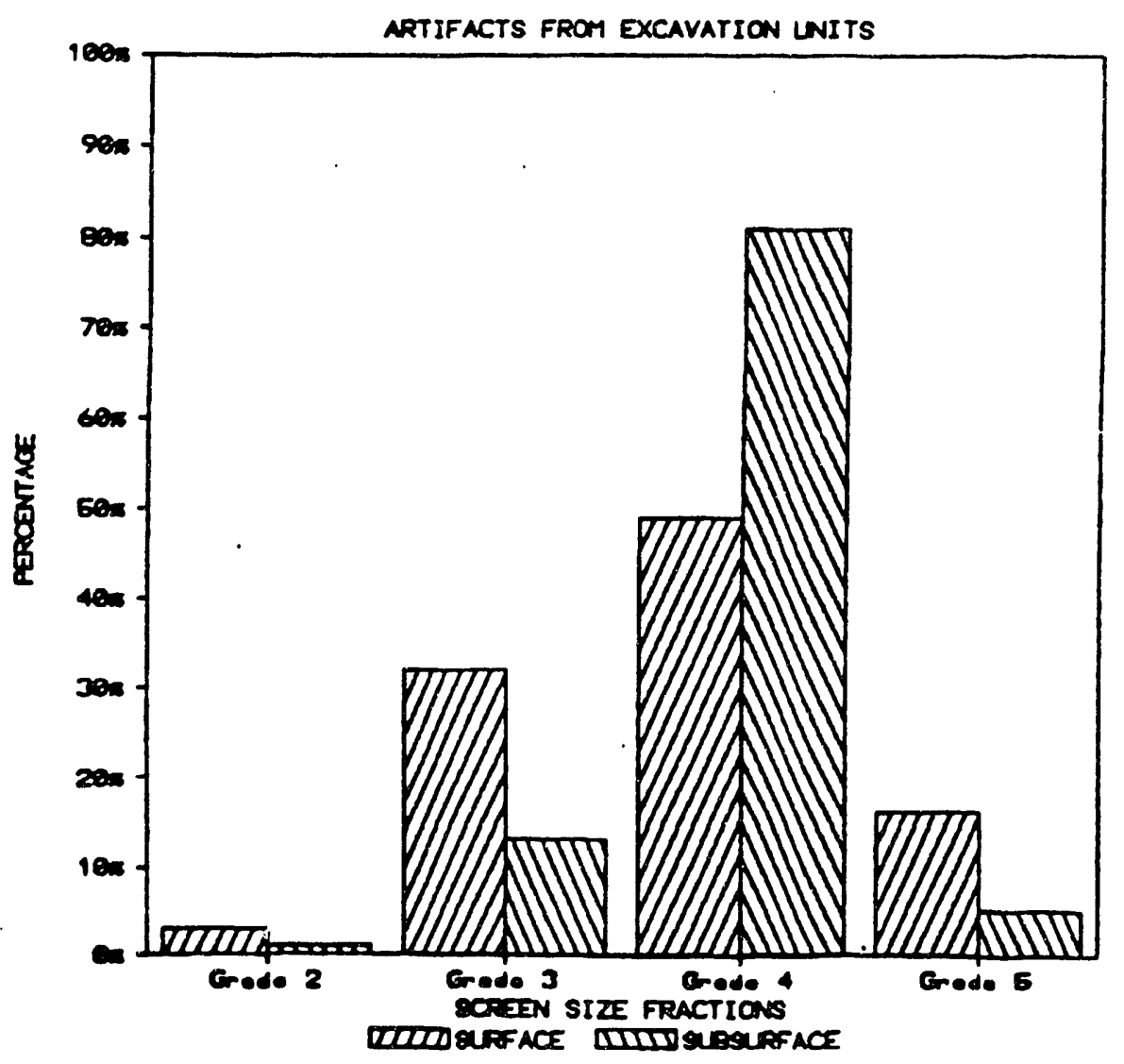

Figure 6-3. Histogram of size grade distributions for surface and subsurface artifact assemblages from the excavation units at $26 \mathrm{Ny} 4892$.

sized artifacts below the surface indicate that some size sorting is occurring at the site. Baker (1978) has noted that downward movement of smaller artifacts into the sediment matrix is the cause of surface size sorting.

The demonstration that smaller artifacts are more common in the subsurface deposits at $26 \mathrm{Ny} 4892$ suggests that some vertical movement has taken place within the deposits. However, the shallow $5 \mathrm{~cm}$ depth of cultural deposits indicates that vertical movement and size sorting have been minimal. Nonetheless, it must be recognized that interpretations of the surface assemblage and its comparison with other assemblages may be affected by differential size sorting. In particular, the 26 Ny4892 surface assemblage is probably lacking a portion of the smaller sized component. If the excavation assemblages are representative of the assemblage as a whole, then the surface and subsurface size grade frequencies may be combined to indicate an expected size grade distribution for the entire assemblage. Table 6-4 presents the combined surface and subsurface frequencies from the excavation units by size grade fraction. The table also shows the surface frequencies and the difference between the surface and combined frequencies.

These figures indicate that the frequency of surface artifacts in Grade 2 may be overrepresented by $0.87 \%$, Grade 3 may be overrepresented by $6.65 \%$, Grade 4 may be underrepresented by $11.33 \%$, and Grade 5 may be overrepresented by $3.82 \%$. The greater proportion of Grade 5 flakes in the surface assemblage contradicts the expected pattern of size sorting effects. This deviation may reflect the effects of different recovery techniques. Subsurface excavations were screened through $1 / 4$-inch 
TABLE 6-4. SIZE GRADE DIFFERENCES BETWEEN SURFACE AND COMBINED SURFACE AND SUBSURFACE ASSEMBLAGES FROM THE EXCAVATION UNITS.

\begin{tabular}{|c|c|c|c|c|c|}
\hline \multirow[t]{2}{*}{$\begin{array}{l}\text { Size } \\
\text { Grade }\end{array}$} & \multicolumn{2}{|c|}{$\begin{array}{l}\text { Combined Surface } \\
\text { and Subsurface }\end{array}$} & \multicolumn{2}{|l|}{ Surface } & $\begin{array}{c}\text { Difference } \\
\text { (Combined minus Surface) }\end{array}$ \\
\hline & $\#$ & $\%$ & $\#$ & $\%$ & $\# \quad \%$ \\
\hline 2 & 9 & (02.26) & 8 & (03.13) & $1 \quad(-\infty .87)$ \\
\hline 3 & 101 & (25.38) & 82 & (32.03) & $19 \quad(-06.65)$ \\
\hline 4 & 241 & $(60.55)$ & 126 & (49.22) & $115(+11.33)$ \\
\hline 5 & 47 & $(11.81)$ & 40 & (15.63) & $7 \quad(-03.82)$ \\
\hline
\end{tabular}

mesh while no minimum size requirements were imposed on surface collections. These estimates on the effects of size sorting are presented to show that biases exist in the surface collections.

These biases are significant because strong associations exist between size grades and technological indicators. Table 6-5 presents the frequencies of obsidian flake types by size grade from the $26 \mathrm{Ny} 4892$ surface assemblage. Cells of the table include the observed value (O), the expected value (E), and the square root of the cell's chi-square value $(z)$. The $z$ statistic is calculated as the observed minus the expected frequency divided by the square root of the expected frequency for each cell. Each $z$ value is squared and summed to yield the chi-square statistic for the entire table. The signs and the magnitudes of the $z$ statistics serve two important roles in interpretation. A positive sign indicates that the observed frequency is greater than expected (under a standard normal distribution) while a negative sign indicates that the observed frequency is less than expected. The magnitude of the $z$ statistic indicates its relative degree of deviance from expected (under the standard normal distribution). Following the conventions of Koopmans (1987:415-419), each z value is compared to standard normal critical values (snc) with the following symbols: ". " for $z<90 \%$ confidence coefficient; " 0 " for $z \geq 90$ and $<95 \%$; "O" for $z \geq 95$ and
< 99\%; and “@” for z z99\% confidence coefficient. Cells with “snc=@” pinpoint categories which have interesting differences between observed and hypothetical frequencies.

Table 6-5 shows that certain flake types tend to be associated with different size grades. Ahler (1989b:87; also see McHugh and Mitchum 1981) has noted that "[t]his apparent correlation between flake type and flake size further compounds interpretation of flake type frequency data." In particular, the large size grades are biased toward recovery of decortication flakes at the expense of the other categories at $26 \mathrm{Ny} 4892$. This patterned association of early stage debris with large size grades and later stage debris with small size grades is not unexpected. However, significant biases may result from this size grade patterning which in turn may affect archaeological interpretations of the flake assemblage. If the recovery of representative samples of small size grade flakes requires (shallow) subsurface excavation, then it is likely that late stage debris like biface thinning, retouch, and indeterminate flakes will be underrepresented in surface collection assemblages. It is clear from these results that the proportions and types of bifaces, cores, and other artifact types may also be affected by differential surface size sorting.

These data suggest that some biases exist in the $26 \mathrm{Ny} 4892$ surface assemblage. Howev$\mathrm{er}$, determination of the exact magnitude and 
TABLE 6-5. CROSS-TABULATION OF OBSIDIAN FLAKE TYPE FREQUENCIES BY SIZE GRADE FROM THE 26NY4892 SURFACE ASSEMBLAGE.

\begin{tabular}{|c|c|c|c|c|c|}
\hline \multirow[b]{2}{*}{$\begin{array}{l}\text { Size } \\
\text { Grade }\end{array}$} & \multicolumn{4}{|c|}{ Flake Type } & \multirow[b]{2}{*}{ Totals } \\
\hline & $\begin{array}{l}\text { Decorti } \\
\text { cation }\end{array}$ & $\begin{array}{l}\text { Core } \\
\text { Reduction }\end{array}$ & $\begin{array}{l}\text { Biface } \\
\text { Thinning }\end{array}$ & $\begin{array}{l}\text { Indeter } \\
\text { minate }\end{array}$ & \\
\hline 2 & $\begin{array}{l}O=116 \\
E=70 \\
z=5.6 \\
\text { snc }=@\end{array}$ & $\begin{array}{l}O=23 \\
E=44 \\
z=3.2 \\
\text { snc }=@\end{array}$ & $\begin{array}{l}O=3 \\
E=9 \\
z=2.0 \\
\text { snc }=0\end{array}$ & $\begin{array}{l}O=9 \\
E=28 \\
z=3.6 \\
\text { snc }=@\end{array}$ & 151 \\
\hline 3 & $\begin{array}{l}O=1640 \\
E=136.7 \\
z=7.4 \\
\text { snc }=@\end{array}$ & $\begin{array}{l}O=897 \\
E=875 \\
z=0.8 \\
\text { snc }=.\end{array}$ & $\begin{array}{l}O=99 \\
E=177 \\
z=5.9 \\
\text { snc }=@\end{array}$ & $\begin{array}{l}O=336 \\
E=553 \\
z=9.2 \\
\text { snc }=@\end{array}$ & 2972 \\
\hline 4 & $\begin{array}{l}O=639 \\
E=928 \\
z=9.5 \\
\text { snc }=@\end{array}$ & $\begin{array}{l}O=614 \\
E=594 \\
z=0.8 \\
\text { snc }=.\end{array}$ & $\begin{array}{l}O=187 \\
E=120 \\
z=6.1 \\
\text { snc }=@\end{array}$ & $\begin{array}{l}O=578 \\
E=376 \\
z 1=0.4 \\
\text { snc }=@\end{array}$ & 2018 \\
\hline 5 & $\begin{array}{l}O=12 \\
E=42 \\
z=4.7 \\
\text { snc }=@\end{array}$ & $\begin{array}{l}O=6 \\
E=27 \\
z=4.1 \\
\operatorname{snc}=@\end{array}$ & $\begin{array}{l}O=23 \\
E=6 \\
z=7.5 \\
\text { snc }=@\end{array}$ & $\begin{array}{l}O=51 \\
E=17 \\
z=8.2 \\
\text { snc }=@\end{array}$ & 92 \\
\hline Totals & 2407 & 1540 & 312 & 974 & 5233 \\
\hline
\end{tabular}

Key: $\quad$ Chi-square $=631.26$, of $=9, p<.000001,0=$ observed trequency,

$E=$ expected frequency, $z=$ cell residuals, snc $=$ standard normal curve

significance of these differences lies beyond the statistical capabilities of these data since the artifactual material from the excavation units is less than $5 \%$ of the total assemblage. The recognition of these biases suggests that caution be exercised in comparing regional surface collection assemblages. Downward movement of artifacts is likely to vary according to different depositional matrices and surface histories, as well as other factors.

\section{Technological Analysis}

Analysis of the Buckboard Mesa artifacts followed laboratory methods and procedures which have been discussed previously in DRI archaeological work at the Nevada Test Site (e.g., Pippin 1986:132-142, Appendix A:39-42; Lockett 1988:39-61). During analysis it became apparent that the reduction of different raw material types produced distirictive by-products. The majority of debris resulted from on-site procurement and reduction of small obsidian nodules. As a result, classification efforts focused on distinguishing distinctive by-products related to the Timber Mountain obsidian nodule technology. Discussion of the general structure of this technology is useful before considering the artifact categories and the interpretation of by-products.

Reno and Pippin (1985:114-125) have reported on a similar small obsidian nodule quarry, known as the Butte Wash Site (26Ny3121), located at the northern end of Yucca Flat. All of the obsidian in these deposits is less than $4 \mathrm{~cm}$ in diameter which is similar in size to the Timber Mountain obsidian gravels at Buckboard Mesa. However, the Butte Wash obsidian nodules are dispersed within sitty sediments in comparison to the dense desert pavement scatter at Buckboard Mesa. Like Buckboard Mesa, the Butte Wash 
matrix also includes minor amounts of vein opal nodules similar in size and shape to the obsidian. Reno and Pippin (1985:125) suggest that the size and shape of these nodules have limited the technological choices for toolstone reduction. Similar size limitations are evident within the Timber Mountain obsidian nodule technology at Buckboard Mesa. Direct comparisons between the Buckboard Mesa and Butte Wash assemblages are presented in more detail later in this report. However, at this point, it is important to consider the role of these resource limitations and the technological solutions used to solve them.

Obviously, one solution to limited raw material size is to import toolstone from other sources where presumably larger raw materials are available. There is evidence from 26 Ny 4892 which suggests that some chipped stone materials were imported, but it also appears that local technological solutions were devised to ameliorate the limitations imposed by the small obsidian nodules. The particular strategy devised to deal with the small Timber Mountain obsidian nodules appears to be splitting by direct freehand, hard hammer percussion. Nodule splitting is a common approach among many prehistoric, chippedstone industries, which are based upon small nodule exploitation. Splitting a small nodule is usually accomplished by: 1) hammer and anvil percussion, also known as a bipolar technique, or 2) direct freehand percussion.

Raymond (1984) has reported a similar technological strategy used in the exploitation of small Topaz Mountain obsidian nodules in west-central Utah. Experimental work by Raymond suggested that the Topaz Mountain obsidian nodules were probably first split using a bipolar technique. Split nodules of Topaz Mountain obsidian were then flaked across the ventral face by direct, freehand, hard hammer percussion. The cortical periphery of the core's ventral face served as the primary platform for flake production. Once the ventral face of the core became exhausted, it was used as a flaking platform and the core became reoriented as a multidirectional or subconical faceted platform core. Topaz Mountain obsidian quarrying activity was oriented toward the production of broad cortical flakes which were then removed from these locations for further reduction. A few of these flakes also served as cores from which more flakes were produceu. The technology that Raymond (1984) has described is conditioned by small noduie size. Similar techniques and by-products resulting from flaking the ventral face of split nodules have been described from the exploitation of small nodules of East Grants Ridge obsidian in New Mexico (Amick 1987b).

However, the use of a splitting technique is evident on a wide variety of technological byproducts from Buckboard Mesa. Splitting appears to have been a technique for optimizing the use of small spherical toolstone. The use of this splitting technique provided considerably more flexibility in dealing with obsidian nodules of limited size. There are several advantages provided by using the splitting technique in the Timber Mountain obsidian nodule technology: 1) establishment of suitable striking platforms on rounded nodules through nodule splitting, 2) manufacture of other usable by-products, 3) maintenance of a large surface area for large flake production, 4) increased longevity of cores through rejuvenation, 5) efficient thinning of bifaces, and 6) recycling of small scraps of toolstone material. The splitting technique allows technological flexibility, and there is evidence within the 26 Ny4892 assemblage that splitting served as an option throughout the reduction sequence.

The splitting method used in the Timber Mountain obsidian nodule technology does not appear to be the result of a bipolar technique. Although Raymond (1984) suggested that his experimental products of bipolar and direct, freehand, percussion techniques were indistinguishable, his illustrations show compressed and deeply undulating ripples on bipolar products which are generally not evident 
in his direct freehand percussion products. Often the split face of the $26 \mathrm{Ny} 4892$ obsidian artifacts exhibited broad, flat "lozenge shaped" surfaces resembling fractures produced by Raymond (1984) through direct freehand hard hammer percussion of small obsidian nodules. Significant evidence of bipolar fractures and by-products, such as those produced experimentally by Kobayashi (1975), was also absent in the 26 NY4892 collection.

A somewhat related technique for maximizing the amount of workable toolstone has been described by Elston and Zeier $(1984: 82-108)$ at the Sugarloaf obsidian quarries in Southern California. They refer to this method as the Coso technique which is suggested to be a hammer and anvil technique to split cobbles and partially reduced cores by longitudinal thinning. This technique is also used to thin bifaces. Furthermore, as Elston and Zeier (1984:122) point out, the Coso technique seems to be an optimizing strategy to produce larger flake blanks than would be possible otherwise, but it does not maximize the overall yield of obsidian. The Coso technique is employed on large cobbles of poor quality obsidian which further differentiates it from the Timber Mountain obsidian nodule splitting technique.

The by-products of the Timber Mountain obsidian nodule technology appear less systematic than those illustrated by Elston and Zeier (1984) at Sugarloaf. However, the flexible use of a splitting technique throughout the reduction sequence is similar to both of these industries despite differences in obsidian size and quality. In addition, the morphological appearance of the split surface is similar to Raymond's (1984) direct, freehand, percussion results. These split surfaces are usually broad and flat with a deep but broad bulbar scar. Typical split surfaces also possess a large wave prior to the split termination which often nearly plunges in reverse fashion through the artifact. Elston and Zeier (1984:91-100) note that plunging terminations are common at the Sug- arloaf quarries, but plunging (or overshot) terminations are rare at Buckboard Mesa. Split fractures within the obsidian nodule technology at Timber Mountain consistently terminate without hinging or plunging. This difference between Sugarloaf and Timber Mountain obsidian technologies may reflect 1) differences due to nodule size, shape, or quality; 2) different percussion techniques; 3 ) differences in fracture control by the artisans; or 4) some combination of these factors.

Singer and Ericson (1977) have described an alternative small, obsidian nodule, reduction technique from the Bodie Hills quarries of California. Two basic strategies are recognized in Bodie Hills obsidian reduction: 1) blade production from prepared cores and 2) biface production. Both strategies employ nodule splitting. Blade production is performed with either polyhedral or prepared platform blade cores. In contrast, the Timber Mountain obsidian nodule technology does not appear to involve a blade production component at all. Bodie Hills blade manufacture is related to later period production and exchange networks among peoples who were more socioeconomically complex than hunter-gatherers in the southern Great Basin. The different cultural context of the Bodie Hills quarries may account for differences in the technological treatment of these obsidian nodules. Biface production at Bodie Hills occurs on large blades and flaked cobble preforms. There are similarities to this strategy in the Timber Mountain obsidian nodule technology, in that bifaces may be produced from nodules, split nodules, or large flakes. The use of a nodule splitting technique to maximize the production of large flake blanks appears to be the most common strategy at Buckboard Mesa. However, for the most part, the production of bifaces from Timber Mountain obsidian nodules is highly flexible. Nodules, split nodules, and flakes all serve as potential bifacial blanks.

Comparison of the similarities and differences to other obsidian nodule technologies 
may provide a framework for understanding the Timber Mountain obsidian nodule reduction strategy. For example, the apparent insignificance of bipolar techniques at Buckboard Mesa is noteworthy. The use of bipolar techniques was suspected as a possible technological solution to the small nodule size of the Timber Mountain obsidian. Bipolar reduction has been recognized as an important technique among similar small nodular materials (e.g., Teilhard de Chardin and Pei 1932; Honea 1965; Chapman 1975; Raymond 1984). However, there is no significant evidence in the Buckboard Mesa assemblages of distinctive bipolar fractures or its by-products (e.g., Binford and Quimby 1963; Kobayashi 1975; Leaf 1979; Boksenbaum 1980; Hayden 1980). In addition, no supporting anvil stones (which are required by the bipolar technique) were found at the Buckboard Mesa sites. It is doubtful that anvil stones would have been transported away from the quarry since suitable anvils are usually immediately available. In general, obsidian's characteristic brittleness may not be conducive to the use of highly compressive bipolar techniques which often shatter the core. Direct freehand, hard hammer percussion appears to be a more conservative technique for splitting obsidian. This technique optimizes the size of usable by-products while minimizing the potential for shattering the nucleus.

The absence of overshot terminations among the split fractures at Buckboard Mesa indicates that a great deal of careful control was exercised in the direct, hard hammer splitting. However, the small size and relatively thick cross-section of the Timber Mountain obsidian nodules and flaking by-products may inhibit overshot terminations. Plunging failures most commonly occur during biface thinning operations (e.g., Elston and Zeier 1984; Johnson 1981) which may suggest that it is a function of relative core thickness as well as excessive percussive force. In any case, Timber Mountain obsidian splitting strategies are not a wasteful strategy. Percussive split- ting also provides considerable flexibility in the Timber Mountain obsidian nodule reduction system through effective artifact thinning, manufacture of usable by-products, and reorientation of the reduction trajectory (especially between cores and bifaces). Overall, this technique appears to represent an effective strategy for exploiting small obsidian nodules in a region where obsidian sources are scarce.

The rigorous analysis of the $26 \mathrm{Ny} 4892$ lithic assemblage requires a large body of ancillary experimental data. Unfortunately, no controlled reduction experiments have been conducted employing the NTS materials. The accurate interpretation of archaeological lithic debris requires combining this specific ancillary experimental replication program (Ahler 1989a, 1989b:98, in passim) with an interactive analytical strategy (Amick, Mauldin, and Binford 1989). While patterning in the archaeological record is easily demonstrated, the meaning of that patterning is dependent upon the knowledge applied to it. Therefore, experimental programs and lithic resource surveys should be considered as fundamental to the scientific interpretation of these data and necessary to archaeological research designs.

Despite these caveats, there is a great deal of patterning within the $26 \mathrm{Ny} 4892$ lithic assemblage that may be interpreted based upon current understanding about the processes of chipped stone tool manufacture and the sources of its variation. The major principles of chipped stone technology are summarized by Ahler (1989b:89-91) as 1) progressive size reduction, 2) progressive cortex removal, and 3) variation in load application. Factors which appear to be the primary conditioners of variation in chipped stone tool production (after Ahler 1989b:98) are 1) raw material; 2) reduction strategies and goals, and 3) skill and Jiversity of knappers.

\section{Debitage Analysis}

Debitage includes the waste flakes and shatter produced during chipped stone tool manufacture and maintenance. Flakes are 
distinguished from their parent nuclei by evidence of a positive bulb of percussion. Small obsidian nodule splitting typically produces a split cobble nucleus or core with a negative bulb of percussion and a primary decortication flake with a positive bulb of percussion. The dorsal surface of both of these products is completely covered with the cortical rind of the naturally weathered nodule.

The primary by-products of lithic reduction at 26 Ny4892 are waste flakes. Many of the flakes produced from locally available materials (especially obsidian) were probably transported to other locations for further modification or use. Raymond (1984) has suggested that at least $50 \%$ of the flakes produced during reduction of small nodules of Topaz Mountain obsidian were removed from the quarry location. The occurrence of bifacially edged flake blanks of Timber Mountain obsidian at Buckboard Mesa suggests that some flakes were produced for the biface manufacture. Some flakes served as blanks for flake tool (e.g., scraper) production, and some flakes served as cores from which other flakes were produced. Flakes which were modified are classified as cores, bifaces, or flake tools and are discussed within those categories.

In addition, many obsidian flakes may have provided sharp cutting edges without further modification. Casual use of these sharp edges to cut soft materials may not always result in macroscopic edge damage. Therefore, these expedient flake tools are not recognized and are included within the debitage category. On the other hand, some of the waste flakes exhibit edge damage that is not related to intentional use or modification. Surface disturbances due to inadvertent trampling and the recent road construction activities are the most likely agents of this irregular edge damage. The flakes discussed in this section do not show unequivocal evidence of use or subsequent modification and are therefore considered to be waste by-products of lithic reduc- tion. Criteria for distinguishing flake tools are provided in the flake tool discussion.

Classification of the debitage followed a decision tree paradigm which is illustrated in Figure 6-4. The general characteristics of these different flake categories have been presented elsewhere (Pippin 1986:132-142, Appendix A:39-42; Lockett 1988:39-61). Careful study of the debitage paradigm illustrates several important inequalities among the categories due to its hierarchical nature. For correct classification, for example, decortication flakes are noi required to possess intact platforms while core reduction, biface thinning, and pressure flakes must exhibit a platform. Also, flakes with less than $25 \%$ dorsal cortex are not considered decortication flakes. Therefore, biface thinning and core reduction flakes may not possess more than $25 \%$ cortex by definition. Indeterminate flakes are usually distal flake fragments without cortex or with less than $25 \%$ cortex, but this category may also include flakes which the analyst simply had difficulty classifying (Lockett 1988:40). For the purpose of this analysis, it is likely that core reduction and biface thinning of small nodules and cortical flakes may have produced many cortical flakes. As a result, the decortication flake category may be inflated at the expense of these categories. This is especially problematic for evaluating the production of small bifaces on obsidian decortication flakes. Bifacial thinning in these cases may have proceeded at the same time as the "decortication" stage.

The debitage categories are intended to reflect different types and stages of lithic reduction. However, as Ahler (1989b:87; see also Magne 1985) has observed "[f]lakes that might appear to be technology specific, such as bifacial thinning flakes and bipolar flakes, can be produced by multiple technologies." However, the initial size and shape of the toolstone from which the flakes are removed conditions their appearance to a large degree (McHugh and Mitchum 1981; Amick, Mauldin, 


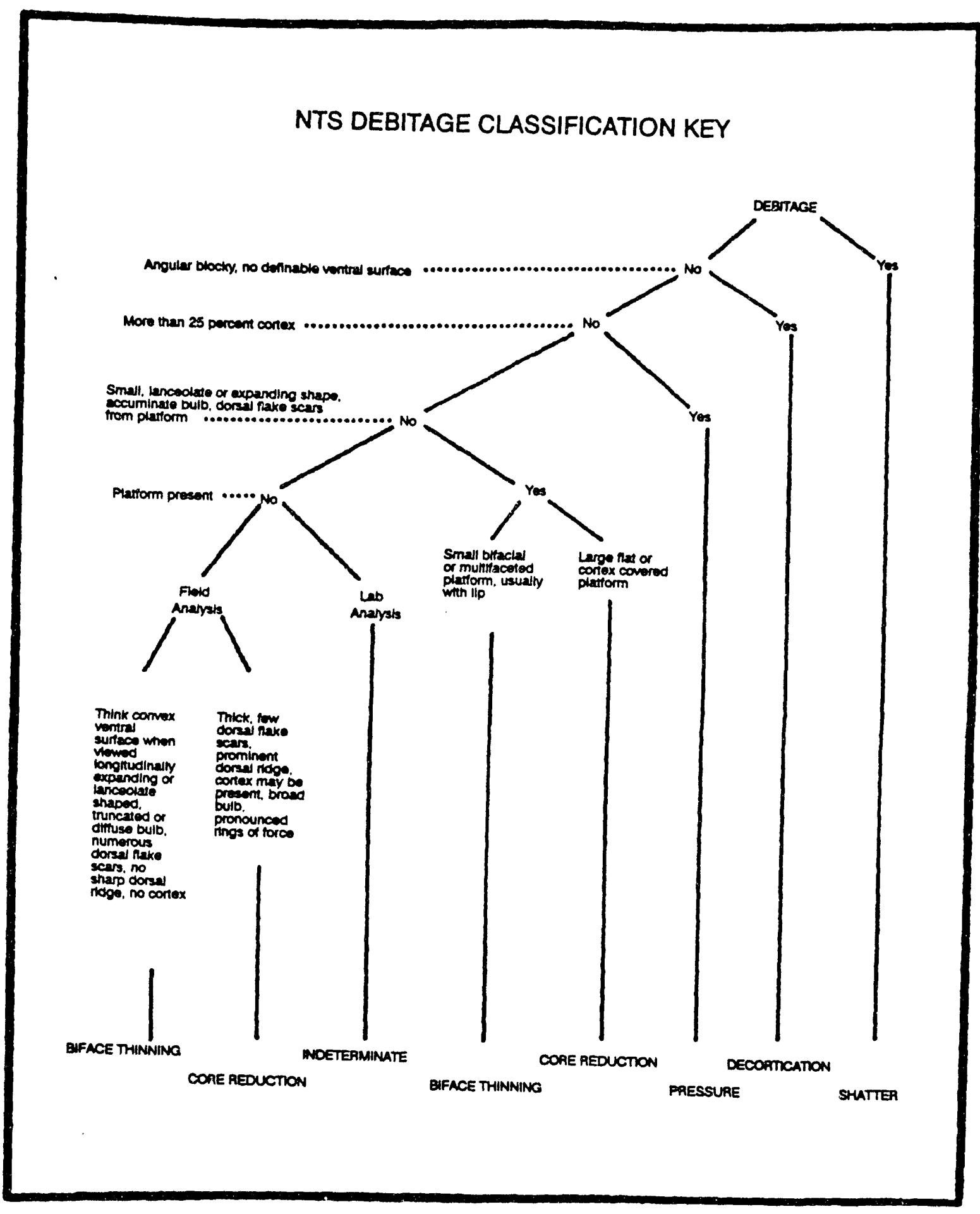

Figure 6-4. Debitage classification key. 
and Tomka 1988; Ahler 1989b:95; Mauldin and Amick 1989). Therefore, material type must be controlled in any analysis of chipped stone.

Only surface debitage is included in this analysis in recognition of biases induced through vertical size sorting. The major category, obsidian, accounts for $92.1 \%(n=6862)$ of the surface debitage. Silicified tuff represents $8.3 \%(n=616)$ of the surface debitage. The remainder of the surface debitage is classified as vein opal $(0.3 \%, n=18)$ or chert/chalcedony $(<0.1 \%, n=3)$. About $22 \%(n=1524)$ of the surface obsidian debitage was not size graded or classified according to flake type categories. These flakes are omitted from the following analysis. Table 6-6 presents frequencies of different flake types by material type for the analyzed surface assemblage.

The three chert/chalcedony flakes may be misclassified vein opal flakes since the vein opal sometimes appears chalcedonic. Chert/ chalcedony rocks are not local, and it is unlikely that decortication and core reduction flakes would be produced from imported materials. Extremely limited reduction of local vein opal nodules seems to be represented at 26Ny4892. Silicified tuff reduction represents a larger but still minor component of producing chipped stone tools. As noted earlier, silicified tuff is also locally available and the relatively high percentages of indeterminate and core reduction flakes (CRFs) probably reflect core reduction oriented toward large flake production. Some limited bifacial reduction of silicified tuff is suggested by the 61 biface thinning flakes (BTFs). This modest frequency of BTFs $(9.9 \%)$ may simply indicate bifacial core reduction strategies or analytical ambiguity in distinguishing between BTFs from CRFs.

Clearly, the most prolific lithic reduction activity at $26 \mathrm{Ny} 4892$ centered upon exploitation of local obsidian nodules. Nearly half (45.1\%) of the obsidian debitage is classified as decortication flakes. CRFs outnumber BTFs by over five to one. These ratios indicate that flake production from small nodules seems to be the predominant obsidian reduction technology. However, as mentioned above, decortication flakes are overrepresented at the expense of other categories in this classification key. In

TABLE 6-6. FLAKE TYPE FREQUENCIES AND PERCENTAGES (C|R) BY MATERIAL TYPE FOR THE ANALYZED SURFACE ASSEMBLAGE FROM $26 N Y 4892$.

\begin{tabular}{|c|c|c|c|c|c|c|}
\hline \multirow[b]{2}{*}{ Material } & \multicolumn{6}{|c|}{ Flake Type } \\
\hline & Decort & CRF & BTF & Pres & Shat & Indet \\
\hline $\begin{array}{l}\text { Obsidian } \\
C \mid R\end{array}$ & $\begin{array}{l}2407 \\
45.1 \%\end{array}$ & $\begin{array}{l}1540 \\
28.8 \%\end{array}$ & $\begin{array}{l}312 \\
5.8 \%\end{array}$ & $\begin{array}{c}1 \\
<0.1 \%\end{array}$ & $\begin{array}{l}104 \\
1.9 \%\end{array}$ & $\begin{array}{l}974 \\
\quad 18.2 \%\end{array}$ \\
\hline $\begin{array}{l}\text { Silicified Tutf } \\
\text { C|R }\end{array}$ & $\begin{array}{l}79 \\
12.8 \%\end{array}$ & $\begin{array}{l}187 \\
30.3 \%\end{array}$ & $\begin{array}{l}61 \\
9.9 \%\end{array}$ & $\begin{array}{l}1 \\
0.2 \%\end{array}$ & $\begin{array}{l}17 \\
2.8 \%\end{array}$ & $\begin{array}{l}271 \\
\quad 43.9 \%\end{array}$ \\
\hline $\begin{array}{l}\text { Vein Opal } \\
\text { C|R }\end{array}$ & 0 & $\begin{array}{l}3 \\
15.8 \%\end{array}$ & $\begin{array}{l}6 \\
31.6 \%\end{array}$ & 0 & 0 & $\begin{array}{l}9 \\
47.4 \%\end{array}$ \\
\hline $\begin{array}{l}\text { Chert/Chalcedony } \\
\text { C|R }\end{array}$ & $\begin{array}{c}1 \\
33.3 \%\end{array}$ & $\begin{array}{l}2 \\
66.6 \%\end{array}$ & 0 & 0 & 0 & 0 \\
\hline
\end{tabular}

Key: $\quad C \mid R=$ Column given row; Flake Types: Decort = Decontication; CRF = Core Reduction Flake; BTF. = Biface Thinning Flake; Pres. = Pressure; Shat. = Shatter; Indet. = Indeterminate. 
addition, the ratio of cortical to noncortical flakes may be larger for smaller materials because surface area becomes larger relative to decreasing volumes. Finally, bifacial reduction of cortical nodules and flakes may result in the production of cortical biface thinning flakes which are classified as decortication flakes in this analysis. Despite these caveats, it is clear that extensive exploitation of small nodules of obsidian is represented at $26 \mathrm{Ny} 4892$.

Size grade frequencies of the $26 \mathrm{Ny} 4892$ surface assemblage debitage are presented in Table 6-7. Comparison of these size grade distributions suggests some additional evidence which may indicate different reduction strategies among different toolstones. The most significant pattern in these data relates to the size differences between obsidian and silicified tuff debitage. Silicified tuff is more dispersed across all size grades with relatively higher frequencies of large and small pieces than the obsidian. This dispersal may indicate that there is less redundancy involved in the reduction of large silicified tuff cobbles. In contrast, obsidian debitage exhibits a more clustered distribution with most flakes found in grade 3 . Obsidian reduction appears to represent a more redundant emphasis on large, broad flake production from obsidian nodules which are more limited in size than the silicified tuff. Experimental data from bifacial reductions (e.g., Ahler 1989a, 1989b; Ahler and Christensen 1983; Amick, Mauldin and Tomka 1988; Henry, Haynes, and Bradley 1976; Mauldin and Amick 1989; Stahle and Dunn 1982, 1984; Tomka 1989) indicate that late stage biface production and rejuvenation would result in greater proportions of grade 4 flakes than are represented by either obsidian or silicified tuff at $26 \mathrm{Ny} 4892$. In addition, the further decrease in flake frequency in size grade 5 reflects minimal evidence for retouch and tool maintenance. The relatively high proportion of silicified tuff in the grade 5 debitage may represent platform preparation on large silicified tuff cores (see Amick, Mauldin, and Tomka 1988 regarding the effect of small platform preparation flakes on size graded flake distributions). However, the general low frequency of flakes in the smaller size grades may be an effect of sampling error. Downward vertical movement of small items in concert with the limitations of surface collecting as a recovery technique may have biased the debitage sample.

Overall, the debitage from $26 \mathrm{Ny} 4892$ primarily reflects initial reduction of obsidian nodules as well as a few silicified tuff cobbles. Both of these reduction systems appear to be oriented toward flake production from cores, but differences in the size, shape, and quality of the natural toolstone condition the manufacturing strategies and by-products. Limited evidence for biface production is found among the waste flakes, but this may be confounded by cortical biface thinning flakes which have been classified as decortication flakes in this analysis.

\section{Flake Tools}

Flake tools within the $26 \mathrm{Ny} 4892$ collection are defined on the basis of regular and continuous retouch or utilization damage. While miany of the flakes produced at $26 \mathrm{Ny} 4892$ may have been used as expedient tools, they are difficult to identify for several reasons. First, many light-duty tasks, such as cutting meat or vegetable materials, may leave no macroscopic edge damage. Secondly, many of the obsidian (glass) artifacts at $26 \mathrm{Ny} 4892$ showed unsystematic crushing and flaking along their edges which were probably a result of prehistoric and historic human trampling, as well as motorized vehicular traffic and other construction activities across the site surface. As noted by the survey reports on this project (Henton 1986a, 1986b), 26Ny4892 was impacted by construction prior to collection and up to $40 \%$ of the impacted area was disturbed in some fashion. Due to these problems in distinguishing the genesis of edge-damaged flakes, criteria for selection as prehistoric tools were strict. Finally, some broad, flat flakes exhibited continuous but shallow bifacial edging. These 
TABLE 6-7. MATERIAL TYPE FREQUENCIES AND PERCENTAGES (R/C) BY SIZE GRADE FOR ANALYZED SURFACE ASSEMBLAGE DEBITAGE FROM $26 N Y 4892$.

\begin{tabular}{|c|c|c|c|c|}
\hline \multirow[b]{2}{*}{$\begin{array}{l}\text { Size } \\
\text { Grade }\end{array}$} & \multicolumn{3}{|c|}{ Material Type } & \multirow[b]{2}{*}{$\begin{array}{c}\text { Chert } \\
\text { Chalcedony }\end{array}$} \\
\hline & Obsidian & $\begin{array}{l}\text { Silicified } \\
\text { Tutf }\end{array}$ & $\begin{array}{l}\text { Vein } \\
\text { Opal }\end{array}$ & \\
\hline $\begin{array}{c}1\left(>2^{n}\right) \\
R \mid C\end{array}$ & 0 & $\begin{array}{c}5 \\
0.8 \%\end{array}$ & 0 & 0 \\
\hline $\begin{array}{c}2(2-1 ") \\
R \mid C\end{array}$ & $\begin{array}{c}155 \\
2.9 \%\end{array}$ & $\begin{array}{c}69 \\
11.2 \%\end{array}$ & 0 & 0 \\
\hline $\begin{array}{c}3(1-1 / 2 ") \\
R / C\end{array}$ & $\begin{array}{c}3031 \\
56.8 \%\end{array}$ & $\begin{array}{c}245 \\
39.6 \%\end{array}$ & $\begin{array}{c}15 \\
78.9 \%\end{array}$ & $\begin{array}{c}3 \\
100 \%\end{array}$ \\
\hline $\begin{array}{c}4\left(1 / 2-1 / 4^{\prime \prime}\right) \\
R \mid C\end{array}$ & $\begin{array}{c}2060 \\
38.6 \%\end{array}$ & $\begin{array}{c}266 \\
43.0 \%\end{array}$ & 4 & 0 \\
\hline $\begin{array}{c}5\left(<1 / 4^{n}\right) \\
R \mid C\end{array}$ & $\begin{array}{c}94 \\
1.8 \%\end{array}$ & $\begin{array}{c}33 \\
5.3 \%\end{array}$ & 0 & 0 \\
\hline \multicolumn{5}{|c|}{$\mathrm{R} \mid \mathrm{C}=$ Row given column } \\
\hline
\end{tabular}

edges were not regularized or straighted as expected for effective use in cutting tasks. Examination of the entire assemblage indicates that these bifacially edged flakes were sometimes further reduced bifacially and thus represent discarded bifacial blanks. Therefore, the bifacially edged flakes are treated during the biface analysis.

Two categories of flake tools are distinguished in this analysis, modified flakes (Figure 6-5a) and utilized flakes (Figure 6-5b). Modified flakes exhibit continuous and intentional retouch to create or resharpen a working edge. For the most part, modified flakes within the 26 Ny 4892 assemblage seem to represent scrapers used on hard materials. On the other hand, utilized flakes are not modified by retouch; they are simply used on an ad hoc basis. Therefore, the identification of utilized flakes depends on the development of macroscopically visible edge damage which is due to use. Utilized flakes are infrequently recognized within the $26 \mathrm{Ny} 4892$ assemblage due to the difficulty in distinguishing edge damage due to prehistoric tool use from fortuitous causes (e.g., trampling, machinery). The accurate identification of flake tools and functional tool-use classifications requires development of an experimental program and specific analytical training in stone tool microscopy.

Comparison of size grade distributions for obsidian debitage and flake tools is presented in Table 6-8. Several significant observations are made from these data. First, less than $1 \%$ of all flakes show unambiguous evidence of tool use. This figure seems quite low and is probably the result of several factors including postdepositionally damaged flakes, conservative identification techniques, and transport of usable flake blanks away from the quarry. Among the flake tools that are found at 26Ny4892, it appears that there was systematic selection of larger obsidian flakes for use as flake tools. A total of $91.3 \%(n=43)$ of the flake obsidian tools are grade 3 or larger while only $59.7 \%(n=3186)$ of the obsidian waste flakes are grade 3 or larger. 


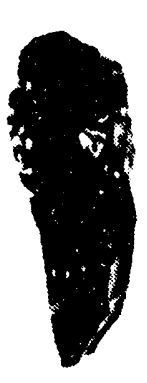

a

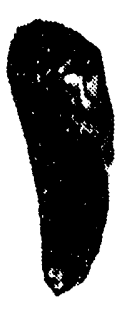

a

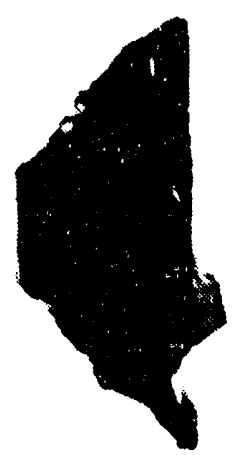

b

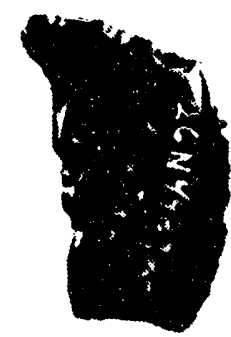

b

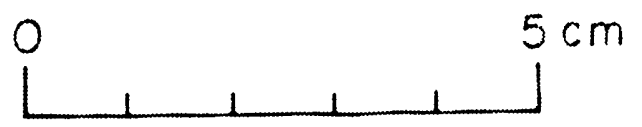

Figure 6-5. Flake tools from 26 Ny4892 (a) Margin views of modified flake tools; b) Planviews of utilized flake tools.

TABLE 6-8. SIZE GRADE DISTRIBUTIONS AND PERCENTAGES FOR OBSIDIAN DEBITAGE AND FLAKE TOOLS FROM $26 N Y 4892$.

\begin{tabular}{cccc}
\hline & \multicolumn{3}{c}{ Artifact Category } \\
\cline { 2 - 4 } $\begin{array}{c}\text { Size } \\
\text { Grade }\end{array}$ & $\begin{array}{c}\text { Analyzed } \\
\text { Debitage }\end{array}$ & $\begin{array}{c}\text { Utilized } \\
\text { Flakes }\end{array}$ & $\begin{array}{c}\text { Modified } \\
\text { Flakes }\end{array}$ \\
\hline $2\left(2-1^{\prime \prime}\right)$ & 155 & 1 & 3 \\
$\mathrm{R} \mid \mathrm{C}$ & $2.9 \%$ & $9.1 \%$ & $8.6 \%$ \\
$3\left(1-1 / 2^{\prime \prime}\right)$ & 3031 & 9 & 29 \\
$\mathrm{R} \mid \mathrm{C}$ & $56.8 \%$ & $81.8 \%$ & $82.9 \%$ \\
$4\left(1 / 2-1 / 4^{\prime \prime}\right)$ & 2060 & 1 & 3 \\
$\mathrm{R} \mid \mathrm{C}$ & $38.6 \%$ & $9.1 \%$ & $8.6 \%$ \\
$5\left(<1 / 4^{\prime \prime}\right)$ & 94 & 0 & 0 \\
$\mathrm{R} \mid \mathrm{C}$ & $1.8 \%$ & 11 & 35 \\
Totals & 5340 & $(0.2 \%)$ & $(0.6 \%)$ \\
$\mathrm{C} \mid \mathrm{R}$ & $(99.1 \%)$ & &
\end{tabular}

Key: $\quad \mathrm{R} \mid \mathrm{C}=$ Row given column; $\mathrm{C} \mid \mathrm{R}=$ Column given row 
Within the flake tools, there seems to be further selectioni of larger flakes for manufacture of modified flake tools while casual flake tools are much smaller. The casual use of small flakes has been noted eihnographically by White (1968). Table 6-9 presents weight statistics comparing utilized flakes to modified flake tools. A one-tailed t-test for means with unequal variances between these values produced a value of -2.3 .9 which is significant at the .02 confidence level. There appears to be a statistically significant difference in the size of the rlake tool types. Modified flakes are almost twice as large as utilized flakes. When a specific flake tool form is required, larger flakes are selected. When an expedient flake tool is desired, smaller flakes are suitable.

All 11 of the utilized flakes are obsidian. Seven $(63.6 \%)$ of these are decortication flakes, $1(9.1 \%)$ is a core reduction flake, and 3 (27.3\%) are indeterminate flakes. Nine $(81.8 \%)$ of the utilized flakes exhibit unifacial damage, 1 (9.1\%) has bifacial damage, and 1 (9.1\%) exhibits compound damage. Utilized flakes may be characterized as small obsidian flakes used for light duty scraping.

Among the modified flakes, 35 are obsidian and 2 are vein opal. Flake types include 17 (45.9\%) decortication, 5 (13.5\%) core reduction, and 15 (40.5\%) indeterminate. Edge morphologies of the modified flake tools exhibit more formal variation. Twenty-one (56.8\%) are unifacially retouched, $2(5.4 \%)$ are bifacially retouched, and $14(37.8 \%)$ exhibit compound edge morphologies. Modified flakes are medium-sized obsidian flakes primarily used for scraping, but they often exhibit multipurpose working edges.

\section{Cores}

Cores are the second most common byproduct of lithic reduction at $26 \mathrm{Ny} 4892$ following the debitage. Cores are basically considered to be any artifact from which pieces have been : amoved by intentional flaking. In general, cores are the nuclei and by-products from which flakes are produced. Core reduction is usually a strategy for the manufacture of flakes which serve as tools or tool blanks. Scrapers are distinguished from cores on the basis of a formalized shape with a unifacial working edge that exhibits use damage. The distinction between cores and bifaces is based upon requirements for bifaces to exhibit the development of a continuous bifacial margin. Therefore, some bifacial flaking is allowed among the cores as long as there does not appear to be any intention to establish and regularize the bifacial margins and bifacially thin the core. Flexıility through the use of the splitting technique often results in products that are difficult to classify as either thin cores or thick bifaces. As a result of this flexibility, it is also possible for the reduction trajectory of an artifact to be reoriented from core to biface to core and so forth. Due to the flexibility of an unsystematic core reduction strategy like that represented at Buckboard Mesa, cores !nay be produced on a variety of nuclei including nodules, split nod-

\section{TABLE 6-9. FLAKE TOOL WEIGHT STATISTICS FOR ALL MATERIAL TYPES (26NY4892)}

\begin{tabular}{|c|c|c|c|c|c|c|c|}
\hline \multirow[b]{2}{*}{$\begin{array}{l}\text { Tool } \\
\text { Type }\end{array}$} & \multirow[b]{2}{*}{$n$} & \multirow[b]{2}{*}{ Mean } & \multicolumn{2}{|c|}{ Weight in Grams } & \multirow[b]{2}{*}{ Median } & \multirow[b]{2}{*}{$\begin{array}{l}\text { 75th } \\
\text { \%tile }\end{array}$} & \multirow[b]{2}{*}{$\begin{array}{l}\text { 25th } \\
\text { \% tile }\end{array}$} \\
\hline & & & $\begin{array}{l}\text { Std } \\
\text { Dev }\end{array}$ & & & & \\
\hline Utilized Flake & 11 & 4.5 & 2.2 & 0.50 & 3.9 & 6.7 & 2. \\
\hline Modified Flake & 37 & 7.0 & 5.1 & 0.72 & 5.4 & 9.6 & 3.6 \\
\hline
\end{tabular}

Key: $\quad n=$ number; Std Dev = standard deviation; $C V=$ coefficient of variation (std. dev. $\times 100 /$ mean) 
ules, quartered nodules, flakes, and even other artifact types.

Like the debitage, there seems to be good evidence that different toolstone types are treated differently among the cores. A total of 364 (including 5 subsurface) obsidian cores (95.8\%), 9 vein opal cores $(2.4 \%)$, and 7 silicified tuff cores $(1.8 \%)$ are represented at 26Ny4892. These proportions are roughly the same as the debitage proportions although the ratio of flakes to cores varies for each material type. Vein opal has a ratio of $18: 9$, or 2 flakes to each core. Although the sample size is small, these figures suggest that the reduction of vein opal cores may often be limited by poor material quality. Reno and Pippin $(1985: 125)$ have noted similar limitations in reducing vein opal nodules from the Butte Wash Site (26NY3121). The ratio of obsidian flakes to cores is 6862:359, or 19 flakes to each core. As noted earlier, Raymond's (1984) experimental and archaeological work with similar materials suggests that this ratio is too low. The actual number of obsidian flakes produced from these cores may be seriously underrepresented in the $26 \mathrm{Ny} 4892$ collection due to the transport of usable flakes from the quarry. Silicified tuff exhibits a ratio of $616: 7$, or 88 flakes per core from the surface assemblage. This figure represents the highest flake to core ratio for any material type at $26 \mathrm{Ny} 4892$.
The larger size of the silicified tuff cobbles may allow for the production of greater numbers of flakes per core.

Table 6-10 presents weight statistics for all of the cores recovered from $26 \mathrm{Ny} 4892$. The size of silicified tuff cores is shown to be at least 10 times larger than obsidian cores. Vein opal cores are closer in size but still at least twice as large as obsidian cores.

Six categories of cores were defined in this analysis. Assayed cores are nuclei from which 3 or fewer flakes have been removed in any orientation (Figure 6-6). The assayed cores also include split cobbles which exhibit only a single negative flake scar which has sheared the nodule in half. These pieces are the result of initial testing and reduction during quarrying. Unidirectional cores have more than 3 flakes removed in the same direction but not necessarily from the same platform (Figure 6-7).

Subconical cores are a distinct morphological class of cores which possess a single platform with systematic flake removals around its periphery resulting in a pyramidal shape (Figure 6-8). Predominantly unidirectional flaking occurs toward the apex of the pyramid, and occasional platform preparation is found on the "base" of the pyramid (which is the top of the core). Although a bifacial margin may develop on subconical cores, there is no

TABLE 6-10. CORE WEIGHT STATISTICS BY MATERIAL TYPE (26NY4892).

\begin{tabular}{lccccccc}
\hline & \multicolumn{7}{c}{ Weight in Grams } \\
\cline { 3 - 7 } $\begin{array}{l}\text { Material } \\
\text { Type }\end{array}$ & $\mathrm{n}$ & Mean & $\begin{array}{c}\text { Std } \\
\text { Dev }\end{array}$ & CV & Median & $\begin{array}{c}\text { 75th } \\
\text { \%tile }\end{array}$ & $\begin{array}{c}\text { 25th } \\
\text { \%tile }\end{array}$ \\
\hline Silicified Tuff & 7 & 475.9 & 494.1 & 1.03 & 236.1 & 724.6 & 224.2 \\
Vein Opal & 9 & 66.0 & 56.3 & 0.85 & 46.5 & 79.3 & 29.6 \\
Obsidian & 364 & 15.6 & 10.6 & 0.68 & 13.8 & 19.8 & 9.2 \\
\hline
\end{tabular}

Key: $\quad n=$ number; Std Dev = standard deviation; $C V=$ coefficient of variation (std. dev. $\times 100 /$ mean) 

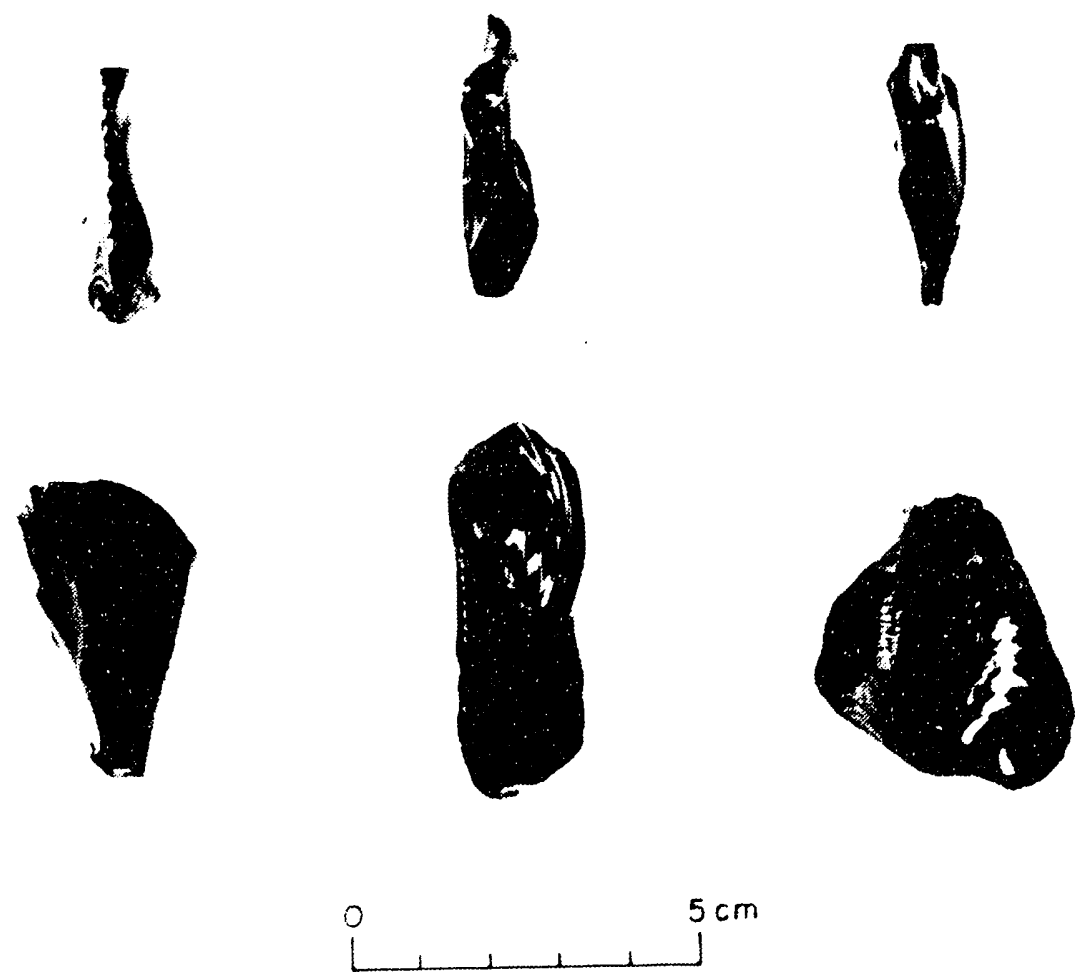

Figure 6-6. Obsidian assayed cores from 26 Ny4892.
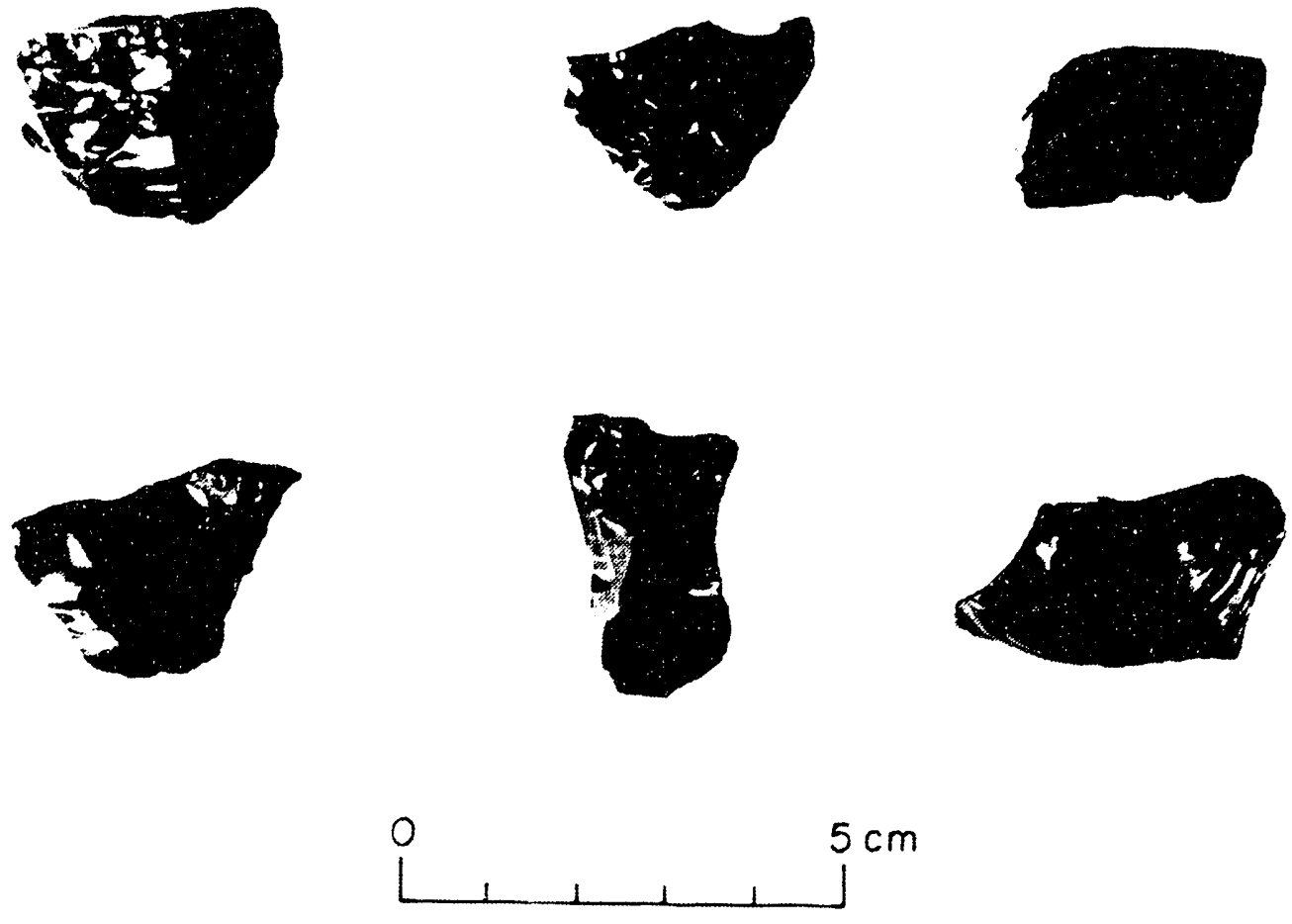

Figure 6-7. Obsidian unidirectional cores from 26 Ny 4892 . 

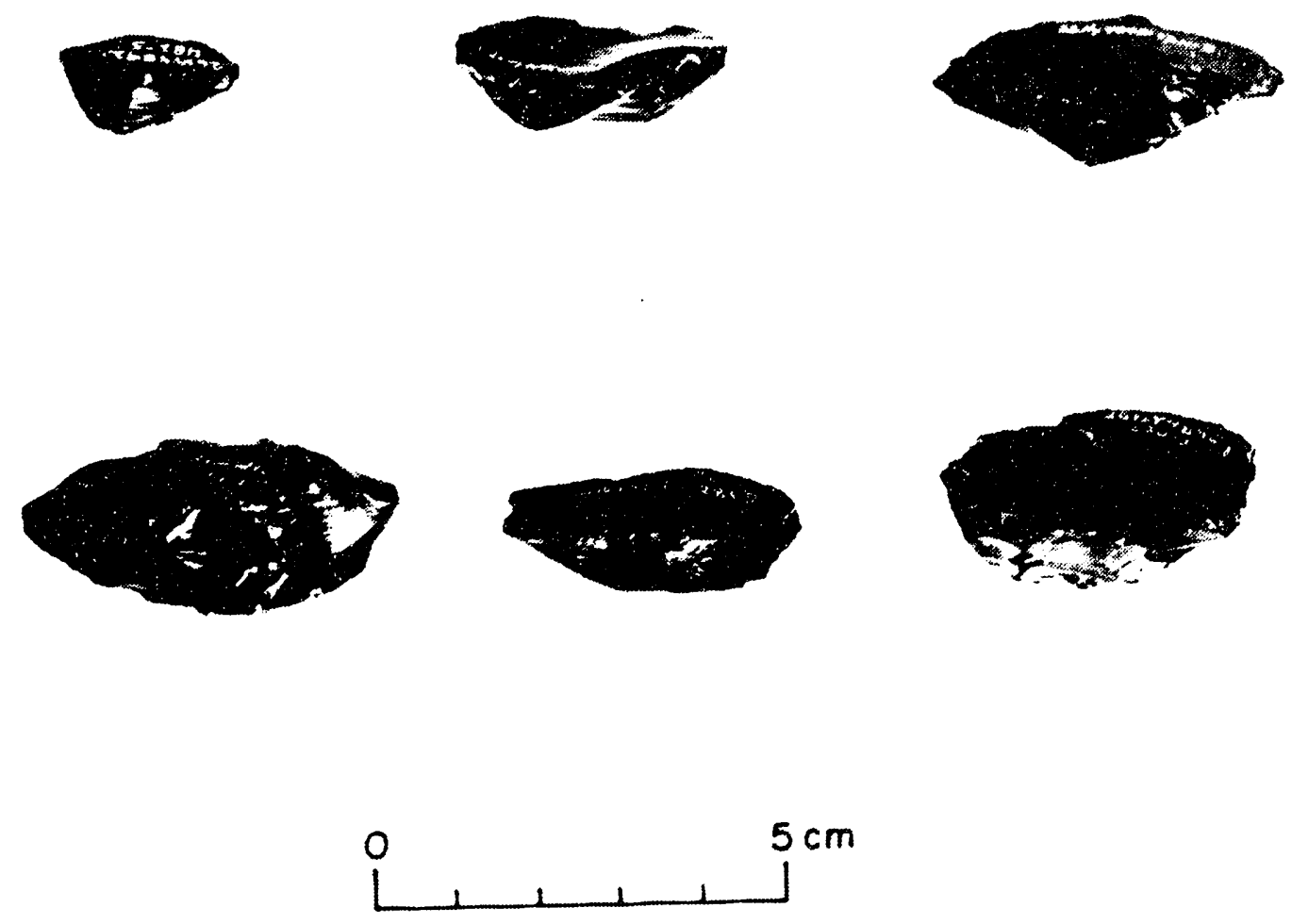

Figure 6-8. Obsidian subconical cores from 26Ny4892.

attempt to center this margin as the primary flake removals are oriented from the base to the apex of the subconical form.

Bidirectional cores exhibit more than 3 flake removals which are limited to 2 directions but not necessarily limited to 2 platforms and not necessarily opposing platforms (Figure $6-9)$. This category may include "bifacial" cores created by the intersection of these two platforms, but the development of a continuous margin in bifacial reduction distinguishes cores from bifaces. Numerous other bidirectional orientations are also possible. Bipolar cores are a special subset of bidirectional cores and represent forms which indicate reduction using a hammer and anvil technique (e.g., Leaf 1979). Indisputable evidence such as opposing bidirectional flaking, crushed/ battered impacts opposing an established platform, columnar spalling, and other unambiguous characteristics of the bipolar technique are required for this classification.
Multidirectional cores have more than three flake removals taken from more than three orientations (Figure 6-10). This strategy is a highly unsystematic technique resulting in what are sometimes called amorphous cores (Johnson 1986, 1987; Parry and Kelly 1987). However, as Patterson (1987) notes, systematic reduction techniques may also produce amorphous cores. These cores are distinguished from bifaces because they do not show development of a continuous bifacial margin, centering of that margin relative to the transverse section, or the systematic thinning that characterizes bifacial reduction. Multidirectional cores often result as cores become exhausted.

Four $(57.1 \%)$ of the 7 silicified tuff cores are multidirectional, $2(28.6 \%)$ are assayed, and 1 $(14.3 \%)$ is subconical. Six $(66.7 \%)$ of the vein opal cores are assayed, 2 (22.2\%) are multidirectional, and $1(11.1 \%)$ is bidirectional. The obsidian cores include 156 (42.9\%) assayed. 

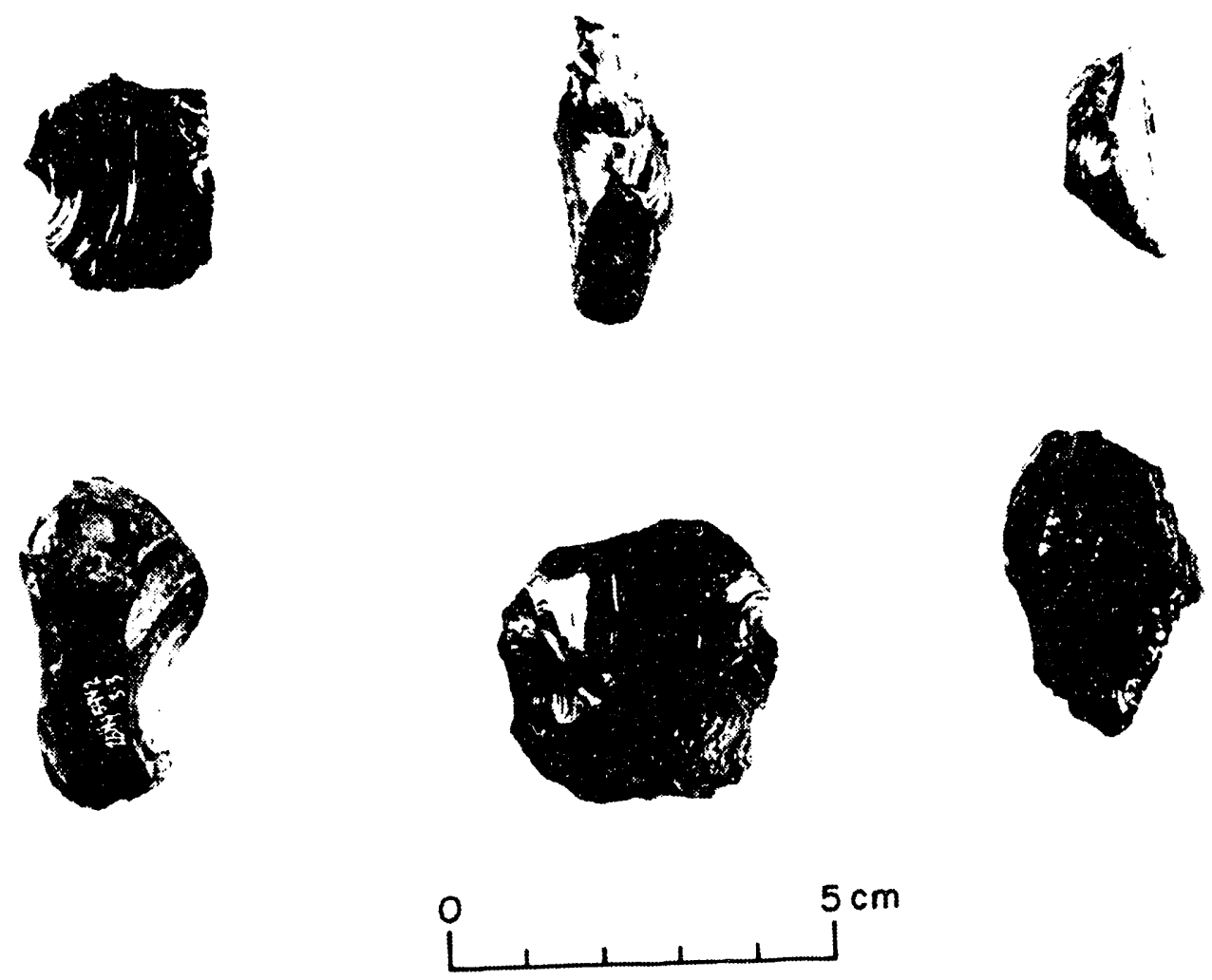

Figure 6-9. Obsidian bidirectional cores from 26 Ny4892.
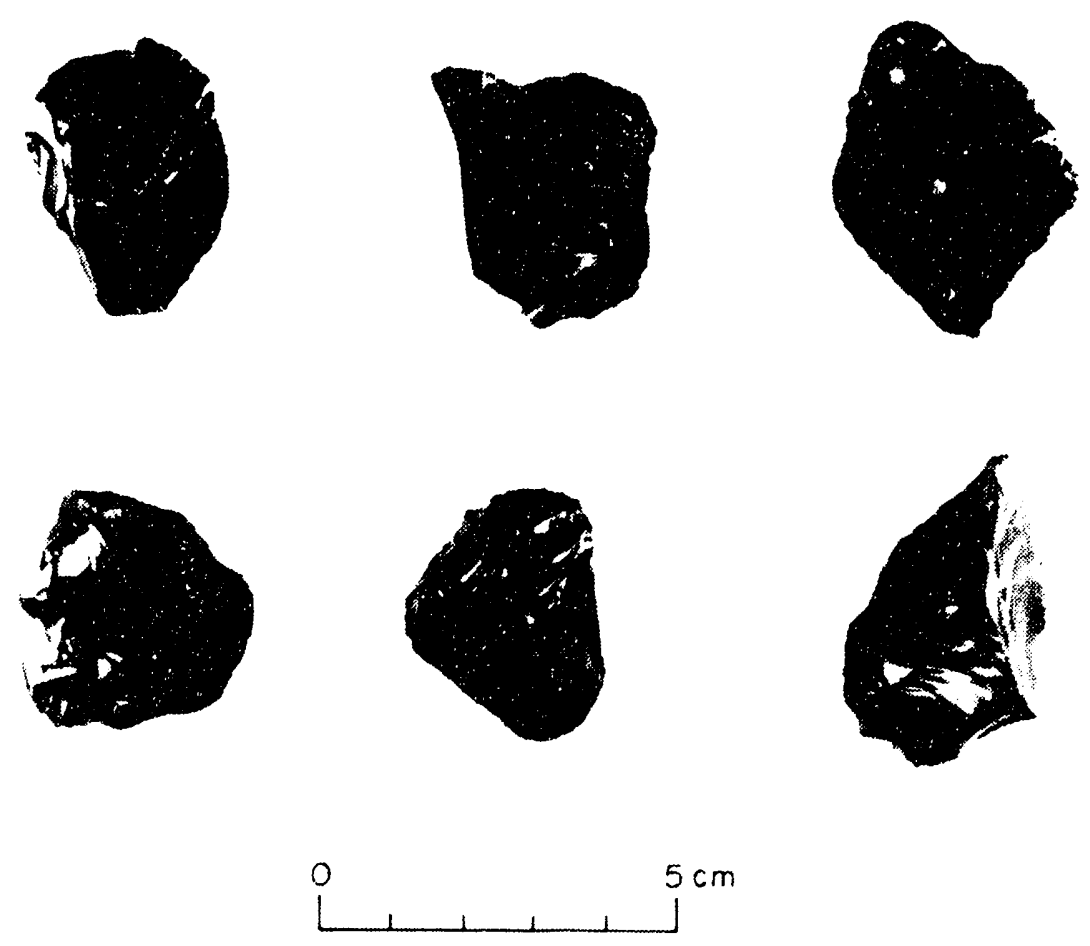

Figure 6-10. Obsidian multidirectional cores from 26Ny4892. 
$129(35.4 \%)$ multidirectional, $33(9.1 \%)$ bidirectional, 30 (8.2\%) subconical, $14(3.8 \%)$ unidirectional, and 1 (0.3\%) bipolar.

Sample size among the non obsidian cores is probably too low to make any meaningful generalizations but the numerous obsidian cores are worth further consideration. The high proportion of assayed obsidian cores suggests that a good deal of nodule procurement and initial reduction occurred at 26Ny4892. In contrast, multidirectional cores also exhibit a relatively high frequency, and these pieces are expected to result from exhaustive lithic reduction. Together, these categories represent $78.3 \%$ of the obsidian cores which may reflect extensive use of materials at this quarry. The other categories are not particularly predominant although the relatively high proportion of subconical cores (8.2\%) suggests somewhat frequent use of this systematic reduction technique. Variation in obsidian core size is illustrated by the weights given in Table 6-11.

The core types are ordered by decreasing mean weights in this table, but there is a great deal of overlap in size range. The similarity in these figures indicates that there may be a general size (about $15 \mathrm{~g}$ ) at which the Timber Mountain obsidian cores become exhausted regardless of the final core form. For comparison, the average weight for natural obsidian nodules of grade 2 size within the toolstone sample is $28.4 \mathrm{~g}(n=15)$. The average weight for natural obsidian nodules of grade 3 size is $5.7 \mathrm{~g}(n=34)$. No nodules larger than grade 2 in size were found in the toolstone sample $(n=1956)$.

While the largest obsidian nodules may have been collected and reduced by the prehistoric inhabitants of $26 \mathrm{Ny} 4892$, it is unlikely that these nodules were much larger than 3 or 4 times the size of the spent cores which remain. Since there are 19 obsidian flakes present to each obsidian core, it seems probable that about half of the material from a single nodule reduction may have been left as debris. The combined total weight of obsidian cores and bifaces is about 6 kilograms which suggests that the yield of usable obsidian from the quarry may have been as low as 3 kilograms from the surface collected area of nearly 15 hectares. These figures are obviously very rough estimates but even if the magnitude of error were two-to threefold underestimate, the yield of this quarry remains substantially low in comparison to aggregated sources of largesized lithic material.

The apparently exhaustive use of these obsidian nodules demonstrates that the benefits of the resource were more than worth the costs of procurement for at least some of the prehistoric occupants. It seems likely that exploita-

TABLE 6-11. OBSIDIAN WEIGHT STATISTICS BY CORE TYPE (26NY4892).

\begin{tabular}{lrrrrrrr}
\hline & \multicolumn{7}{c}{ Weight in Grams } \\
\cline { 3 - 8 } $\begin{array}{l}\text { Core } \\
\text { Type }\end{array}$ & $n$ & Mean & $\begin{array}{c}\text { Std } \\
\text { Dev }\end{array}$ & CV & Median & $\begin{array}{c}\text { 75th } \\
\text { \%tile }\end{array}$ & $\begin{array}{c}\text { 25th } \\
\text { \%tile }\end{array}$ \\
\hline Assayed & 156 & 17.1 & 13.2 & 0.77 & 14.4 & 22.4 & 9.3 \\
Bidirectional & 33 & 16.1 & 9.0 & 0.56 & 12.2 & 20.5 & 9.1 \\
Subconical & 30 & 14.6 & 8.0 & 0.55 & 13.0 & 17.2 & 9.7 \\
Multidirectional & 129 & 14.3 & 7.5 & 0.53 & 12.8 & 17.6 & 8.8 \\
Unidirectional & 14 & 13.5 & 9.8 & 0.73 & 12.1 & 19.2 & 4.1 \\
Bipolar & 1 & 9.5 & - & - & - & - & - \\
\hline
\end{tabular}

Key: $\quad n=$ number; Std Dev $=$ standard deviation; $C V=$ coefficient of variation (std. dev. $\times 100 /$ mean) 
tion of the obsidian nodules at $26 \mathrm{Ny} 4892$ was constrained by technological needs and requirements in conjunction with mobility patterns. The limited size of the Timber Mountain obsidian nodules precluded their use in the production of large artifacts. Obsidian has the advantage of producing razor sharp edges, and, although the edges are not very durable, they are easily retouched. Given the disadvantages of the sparsely distributed small nodules of Timber Mountain obsidian, it seems likely that exploitation occurred during a context when mobility patterns (e.g., Binford 1979) and time stresses (e.g., Torrence 1983) may have constrained options to procure other toolstone materials. In addition, the time required for collection and reduction of the nodules may have conditioned the intensity of quarry use.

Table 6-12 presents distribution statistics for length, width, and thickness measurements on the 364 obsidian cores. These figures show that general core shapes are somewhat more constrained than weights. Weights exhibited a coefficient of variation (CV) of about $60 \%$ whereas metric dimensions have CVs of about $25 \%$. Since the cores are generally produced from small nodules, they tend to be oval in shape. Use of the nodule splitting technique is somewhat responsible for a relatively thin cross section. As a result, many of the cores appear as flattened disks in a typical sense. The evidence that there is more variation in core size (as measured by weight) than core shape (as measured by length, width, and thickness) suggests that nodule geometry is constraining this technology more than nodule size. In fact, the generally thick cross section relative to the small size of the Timber Mountain obsidian nodules may be largely responsible for the use of direct, freehand, hard hammer splitting. The splitting strategy accomplishes optimal production of large flake blanks and thin cores which may be suitable for further bifacial reduction by efficiently thinning the cores (for possible bifacial blanks) while at the same time maintaining relatively large surface areas (for flake production). Of course, considerable variability exists in the employment and success of this strategy as indicated by the variety of by-products recovered at 26 NY4892.

Table 6-13 presents the frequencies of blank types for the cores from 26 NY4892 by material type. These data provide an illustration of the options available for core reduction. Nodules and split nodules seem to be the most common initial forms. Flakes comprise $19 \%$ $(n=69)$ of the total which indicates the exhaustive core reduction of even flake by-products. Newcomer and Hivernel-Guerre (1974) and Goren-Inbar (1988) have discussed similar exhaustive core technologies which employed flakes of similar size. Indeterminate forms result from extensive flaking over the core surface which obscures its original form. The form of the original nucleus is obscured on $21.4 \%(n=78)$ of the obsidian cores which may also reflect the exhaustive use of these

TABLE 6-12. METRIC DIMENSION STATISTICS FOR ALL OBSIDIAN CORES $(N=364)$ FROM 26 NY4892.

\begin{tabular}{lcccccc}
\hline Dimension & Mean & $\begin{array}{c}\text { Std } \\
\text { Dev }\end{array}$ & CV & Median & $\begin{array}{l}\text { 75th } \\
\text { \%tile }\end{array}$ & $\begin{array}{l}\text { 25th } \\
\text { \%tile }\end{array}$ \\
\hline Length & 36.4 & 7.9 & 0.22 & 37 & 41 & 31 \\
Width & 27.5 & 6.0 & 0.22 & 31 & 27 & 24 \\
Thickness & 15.8 & 5.5 & 0.34 & 15 & 19 & 12 \\
\hline
\end{tabular}

Key: $\quad$ Std $\mathrm{Dev}=$ standard deviation; $\mathrm{CV}=$ coefficient of variation 
small pieces. Although sample sizes are low, splitting reduction techniques do not appear to be as significant among the other local materials found at $26 \mathrm{Ny} 4892$.

The obsidian cores illustrate a limited degree of patterning which is dependent upon their original nucleus form. Assayed cores are most commonly produced on nodules and split nodules $(n=122,78.2 \%)$. The original form is indeterminate on $38.8 \%(n=50)$ of the multidirectional cores. Production of unidirectional, bidirectional, and subconical cores appears to be equally distributed between the different nucleus forms. However, the use of flakes is more common for these types $(30-40 \%)$ than among the assayed and multidirectional cores (about 15\%).

Cortex is present on $353(97.2 \%)$ of the obsidian cores which reflects the immediate availability and small size of the obsidian nodules. A total of 124 obsidian cores (34.1\%) have greater than $50 \%$ cortex cover. No cortex was evident on $9(7.0 \%)$ of the cores which are all multidirectional. This observation supports the notion that multidirectional cores represent more exhaustively used nodules in this collection. Further evidence of the complexity of flake scar patterns due to the exhaustive but unsystematic reduction of multidirectional cores is measured by the frequency of discrete cortex relicts (physical features remaining after flakes have been removed). The frequency of cortex relicts was measured by counting the number of discrete "islands" of cortex on the artifact. It is expected that cortex relict isolation increases during early reduction and decreases as cortex becomes more completely removed during later reduction. As a result, cortex relict counts may provide a relative measure of complexity in core reduction from cortical nuclei. Table 6-14 shows that there is a statistically significant association between cortex relict frequencies and cortex cover percentages that supports the use cf cortex relicts as a measure of greater reduction (decortication). Higher cortex relict counts $(\geq 2)$ are associated with less total cortex cover (1-50\%).

Cortex relict counts among the obsidian cores from $26 \mathrm{Ny} 4892$ range up to 5 . Only the more complex core forms exhibit more than 2

TABLE 6-13. MATERIAL TYPE FREQUENCIES BY BLANK TYPE FOR CORES FROM 26 NY4892.

\begin{tabular}{|c|c|c|c|}
\hline \multirow[b]{2}{*}{$\begin{array}{l}\text { Blank } \\
\text { Type } \\
\end{array}$} & \multicolumn{3}{|c|}{ Material Type } \\
\hline & Obsidian & $\begin{array}{c}\text { Sillicified } \\
\text { Tutt }\end{array}$ & $\begin{array}{l}\text { Vein } \\
\text { Opal }\end{array}$ \\
\hline Nodule & 92 & 2 & 8 \\
\hline $\begin{array}{l}R \mid C \\
\text { Split Nodule } \\
R \mid C\end{array}$ & $\begin{array}{l}25.3 \% \\
123 \\
33.8 \%\end{array}$ & $\begin{array}{c}28.6 \% \\
1 \\
14.3 \%\end{array}$ & $\underset{0}{88.9 \%}$ \\
\hline $\begin{array}{l}\text { Quartered Nodule } \\
\text { R|C }\end{array}$ & $\begin{array}{c}2 \\
0.5 \%\end{array}$ & 0 & $\stackrel{1}{11.1 \%}$ \\
\hline $\begin{array}{l}\text { Flake } \\
\text { R|C }\end{array}$ & $\begin{array}{c}69 \\
19.0 \%\end{array}$ & $\begin{array}{c}2 \\
28.6 \%\end{array}$ & 0 \\
\hline $\begin{array}{l}\text { Indeterminate } \\
\text { R|C }\end{array}$ & $\begin{array}{c}78 \\
21.4 \%\end{array}$ & $28.6 \%$ & 0 \\
\hline
\end{tabular}

Key: $\quad R \mid C=$ Row given column 
TABLE 6-14. CROSS TABULATION OF CORTEX RELICTS WITH CORTEX COVER AMONG THE CORTICAL OBSIDIAN CORES FROM $26 N Y 4892$.

\begin{tabular}{crrr} 
& \multicolumn{1}{c}{ Cortex } & \multicolumn{2}{c}{ Relicts } \\
\cline { 2 - 3 } Cortex Cover & \multicolumn{1}{c}{1} & \multicolumn{1}{c}{2} & Totals \\
\hline $1-50 \%$ & $O=160$ & $O=70$ & 230 \\
& $E=183$ & $E=47$ & \\
$>50 \%$ & $O=121$ & $O=3$ & 124 \\
& $E=98$ & $E=26$ & 354 \\
\hline
\end{tabular}

Chi-square 38.63, of $1, p<0.000001$;

Key: $\quad O=$ observed; $E=$ expected

cortex relicts, and these are represented by the multidirectional $(n=9,7 \%)$ and subconical types $(n=6,20 \%)$. In addition, the complete absence of cortex is restricted to the multidirectional $(n=9,7 \%)$ and subconical types $(n=1,3.3 \%)$ as well. This evidence further supports the notion that these core types represent more exhaustive strategies than the other obsidian core forms at $26 \mathrm{Ny} 4892$.

Eight of the 9 vein opal cores from 26 Ny4892 are manufactured from nodules. Five of these are assayed cores, and all 9 of the vein opal cores are cortical. Although the number of vein opal cores is small, they indicate limited reduction from local alluvial nodules. Previous discussions of vein opal exploitation at the NTS have noted the high frequency of unusable quarry debris produced by reduction of these often poor quality materials (e.g., Reno and Pippin 1985). In any case, the exploitation of local vein opal nodules at 26 Ny4892 appears to be greatly overshadowed by the obsidian exploitation.

The modal core type among the silicified tuff cores is multidirectionaland is represented by 4 of the 7 specimens (57.1\%). Silicified tuff cores are produced on a variety of nucleus forms. Atthough all of the silicified tuff cores are cortical, $85.7 \%(n=6)$ possess less than $50 \%$ cortex cover. However, inferences about patterning within this class are limited because of the low sample size. Despite the availability of large silicified tuff cobbles and boulders at 26Ny4892, lithic exploitation focused on much smaller obsidian nodules. These preferences evidently reflect the limited utility of silicified tuff (and most vein opal) in chipped stone tool production.

\section{Bifaces}

Bifaces are a iess common by-product of lithic reduction at $26 \mathrm{Ny} 4892$ than cores which outnumber the bifaces by over 2:1. However, this does not indicate that biface production was unimportant at this site. Many flake blanks and cores which were suitable for small biface production may have been removed for further reduction elsewhere. In addition, successful production of bifaces leaves only biface thinning debris since the bifaces are transported away. Consequently, the bifaces which remained at 26 Ny 4892 for the most part represent manufacturing failures and broken and worn tools. Deposition of a few of the bifaces may have resulted from unintentional loss or failure to recover cached materials.

Previous analyses of bifaces from the NTS area depended upon stage classifications (Pippin 1986:132-142, Appendix A:39-42; Lockett 1988:39-61) which were difficult to apply to the Buckboard Mesa project assemblages. As a result, an alternative approach to defining the biface reduction trajectory was 
employed. This approach requires the determination of artifact weight and planview area and has been developed by Johnson (1981) and others (e.g., Amick 1985, 1987a). Once these two measurements are taken, weight is divided by planview area to provide a thinning index of relative thickness (expressed as grams per square centimeter). Since the general goal of bifacial reduction is to decrease the thickness of an artifact while maintaining width and length, it is based on thinning techniques. Therefore, through the sequence of bifacial reduction, the biface should become thinner relative to overall size. Similar measures which rely on the ratio of width to thickness (referred to as thinning ratio in this analysis) are based on the same principles of bifacial reduction (e.g., Callahan 1979; Ahler and Christensen 1983). The advantage of the thinning index over the thinning ratio is that even fragmentary specimens can be accurately measured. A potential drawback of the thinning index is the time required to determine the artifact planview area (Amick 1987a). Artifact planview area was determined through the digital image processing described by Henton and Durand (1989). This is a rapid and accurate means of determining the planview area of irregular objects.

During the analysis of the bifaces, it became apparent that it was possible to classify many of them according to the blank types from which they were manufactured. Distinguishing the different blank types was easiest for bifaces in the early stages of reduction. Six different biface blank types are defined. First, projectile points are identified based on evidence of haft modification, finished blade edges, pressure flaking, and analogy to previously recognized projectile point shapes. Secondly, late stage bifaces are classified on the basis of advanced bifacial thinning, often with soft hammer percussion (Figure 6-11). Pressure retouch is minimal among late stage bifaces. In addition, they do not show haft modification and are broader than projectile points. Late stage bifaces are analogous to what are sometimes referred to as bifacial preforms although they may have functioned as bifacial cores and/or knives. In any case, bifacial thinning, often by soft hammer percussion, is associated with the later stages of bifacial reduction.

The remaining group of biface blank types represents the earlier stages of reduction where establishment and regularization of bifacial margins, often by hard hammer percussion, is undertaken. Nodule blanks are identified by the presence of rounded cortical margins indicating the biface was produced directly from a small nodule (Figure 6-12). Splitnodule blanks are identified by the presence of the large, flat, negative flake scar surface resulting from nodule splitting as discussed above (Figures 6-13 and 6-14). Edged flake blanks are flakes which show bifacial work along their margins and limited bifacial thinning (Figures 6-15 and 6-16). Indeterminate blanks include those early stage bifaces whose original form cannot be distinguished due to advanced reduction (Figure 6-17).

The relative relationship of the different blank types among the obsidian bifaces at 26 Ny4892 is suggested by decreasing thinning index values in Table 6-15. The generally expected reduction sequence and trajectory relationship of biface blank types is confirmed in these data.

Previous researchers have not compared thinning index values to thinning ratio values. Therefore, an evaluation of the relative effectiveness of these two measures is relevant. Table 6-16 presents the thinning ratio statistics for cores, biface blanks, and modified flake tools. Thinning ratio values increase with advanced reduction rather than decrease like the thinning index. Overall, there is excellent agreement in the ordering of the bifaces by the two measures. The only difference in ordering is that indeterminate blank type bifaces are placed before nodule blanks in the thinning ratio rankings. Given the relative closeness of the thinning index values for nodule blanks 

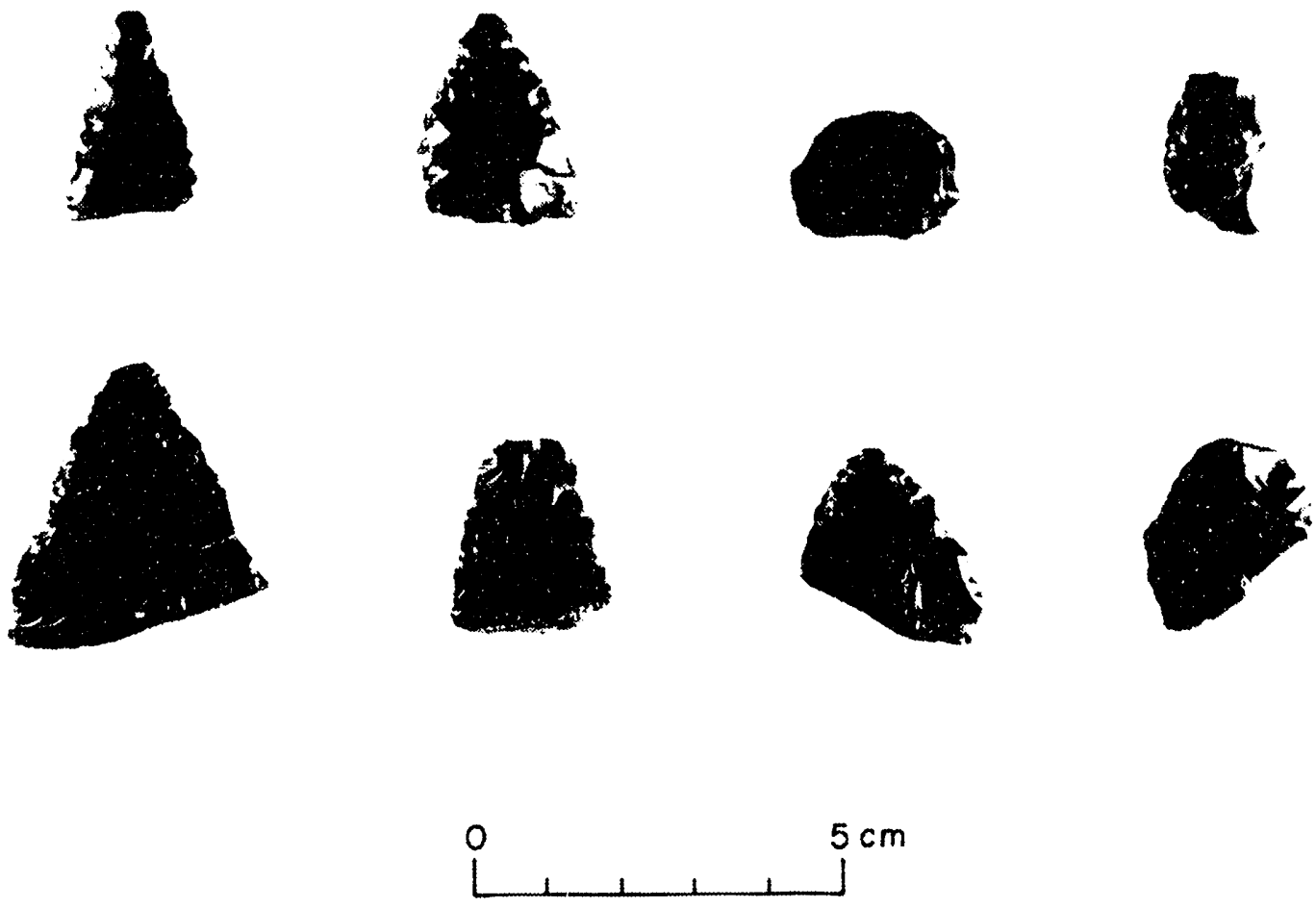

Figure 6-11. Obsidian late stage bifaces from 26 Ny 4892.
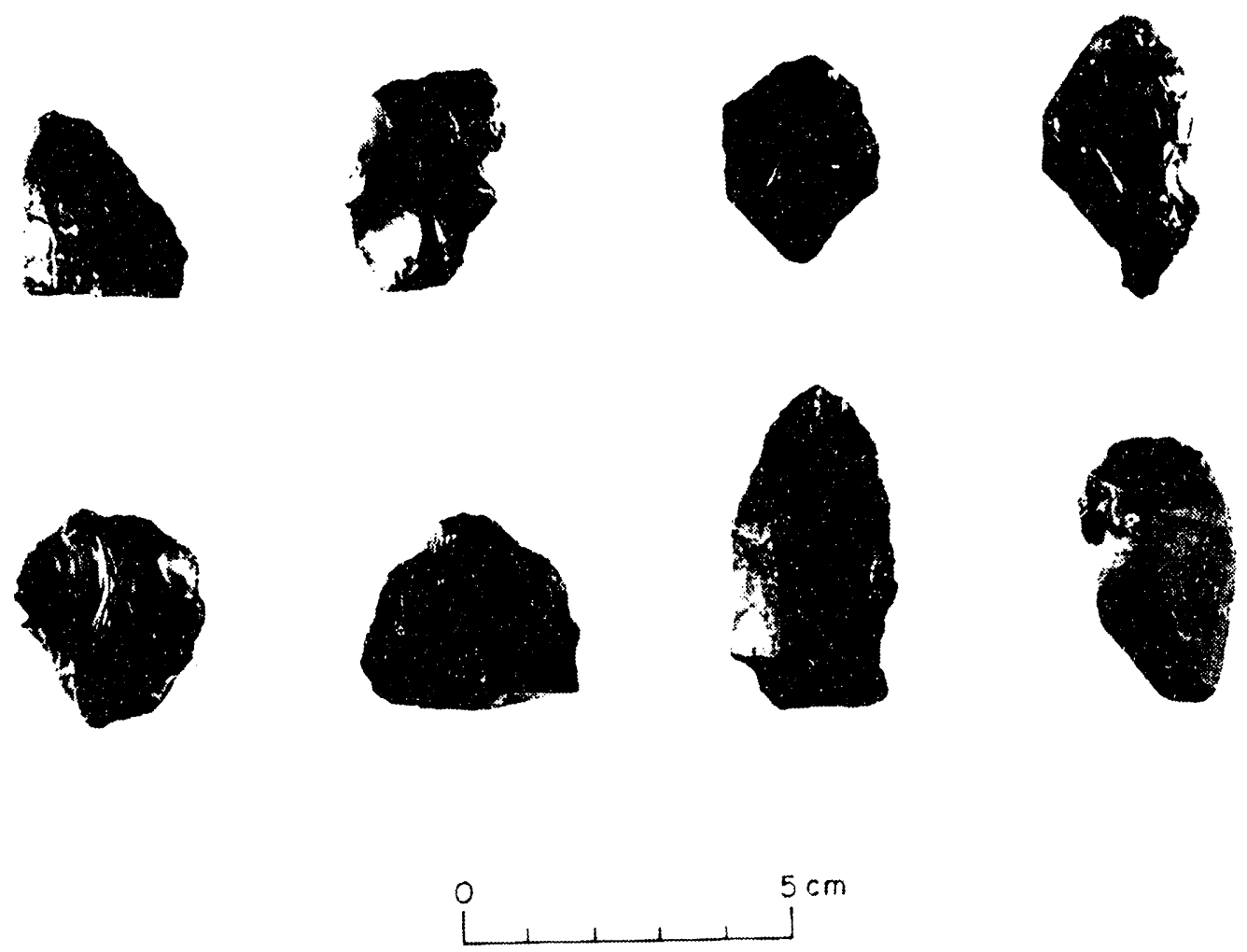

Figure 6-12. Obsidian early stáge bifaces (nodule blanks) from 26Ny4892. 

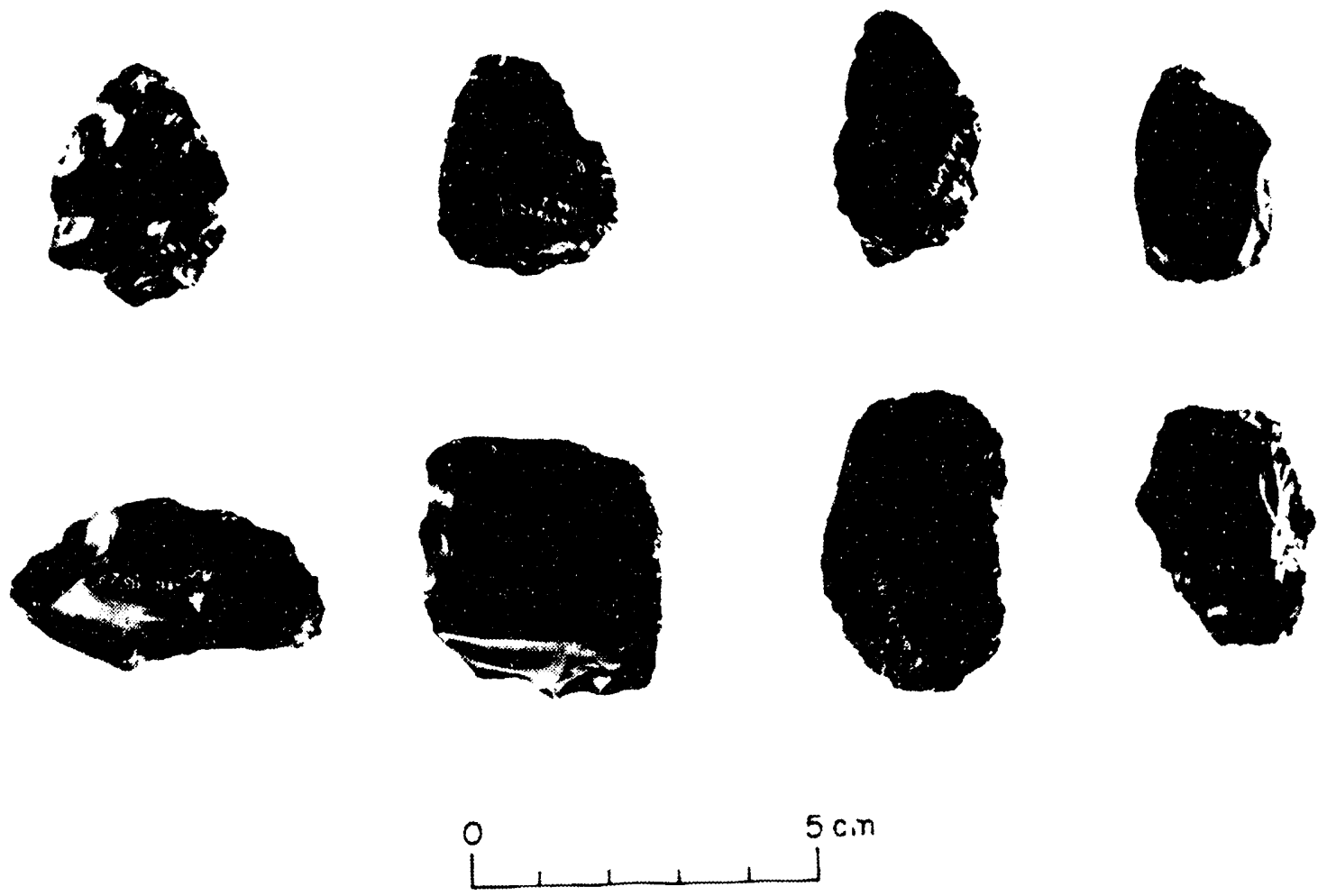

Figure 6-13. Obsidian early stage bifaces (split nodule blanks) from $26 \mathrm{Ny} 4892$.
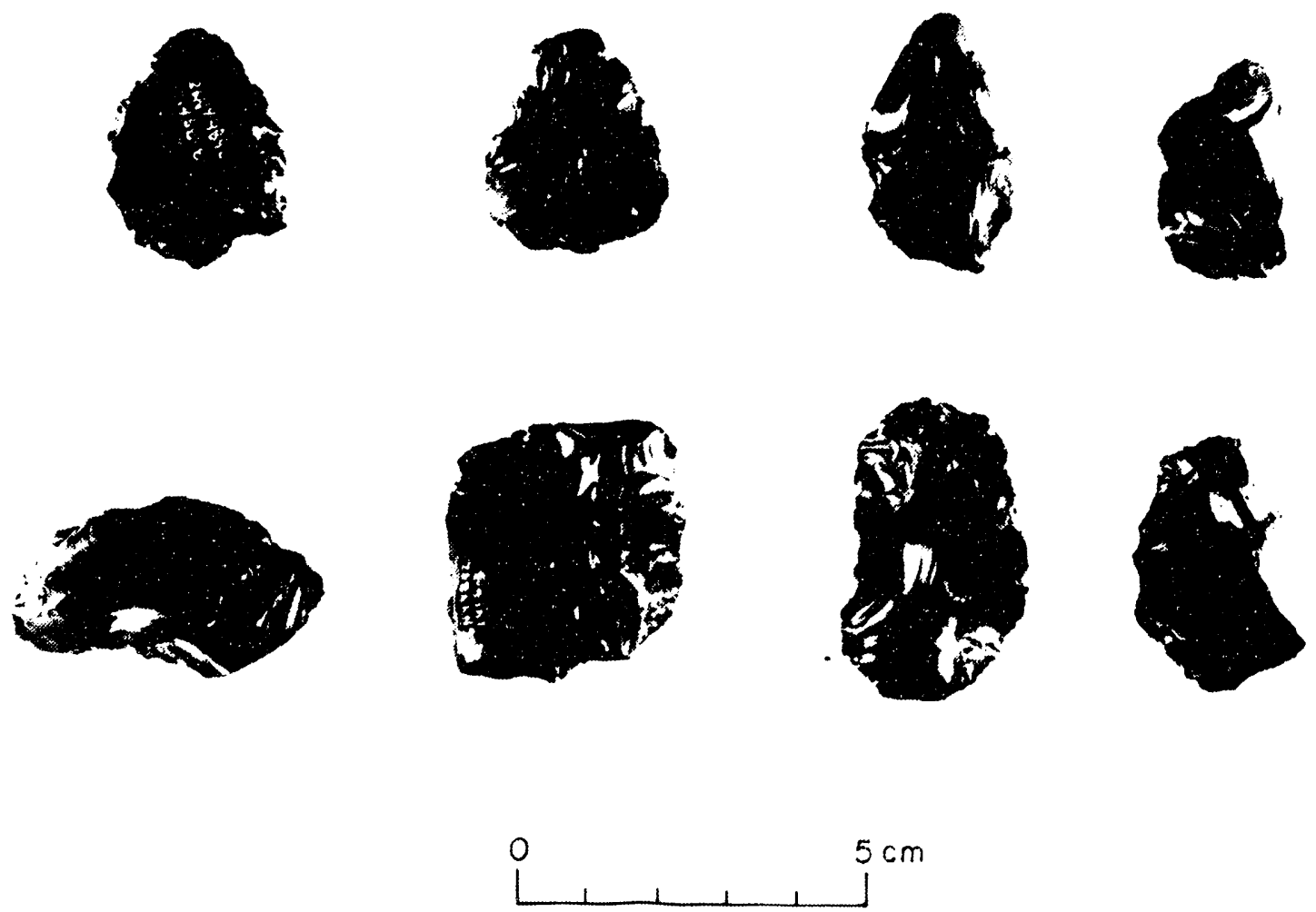

Figure 6-14. Obsidian early stage bifaces (split nodule blanks) from 26Ny4892. Obverse side. 

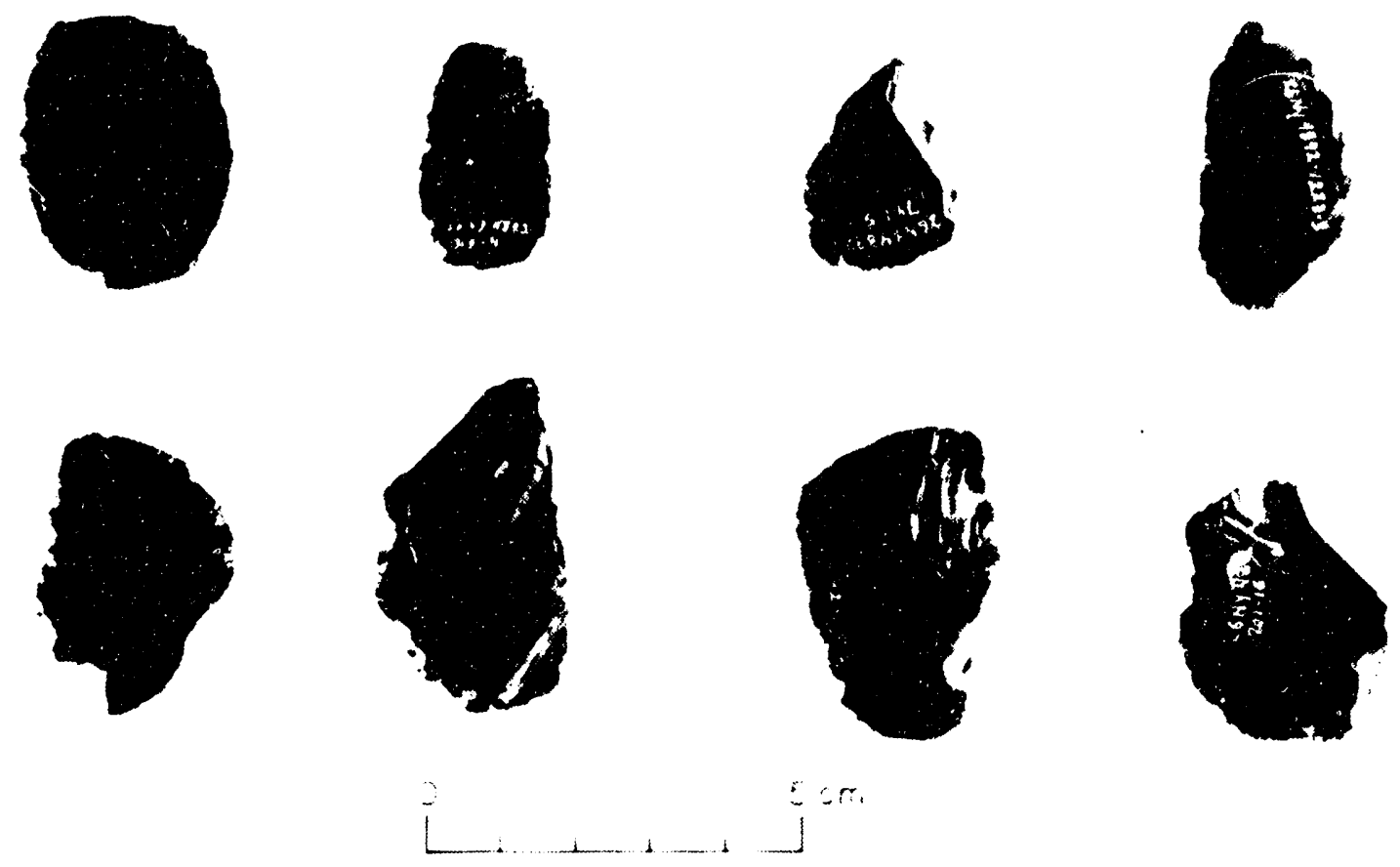

Figure 6-15. Obsidian intermediate stage bifaces (edged flake blanks) from 26Ny4892. Ventral face.
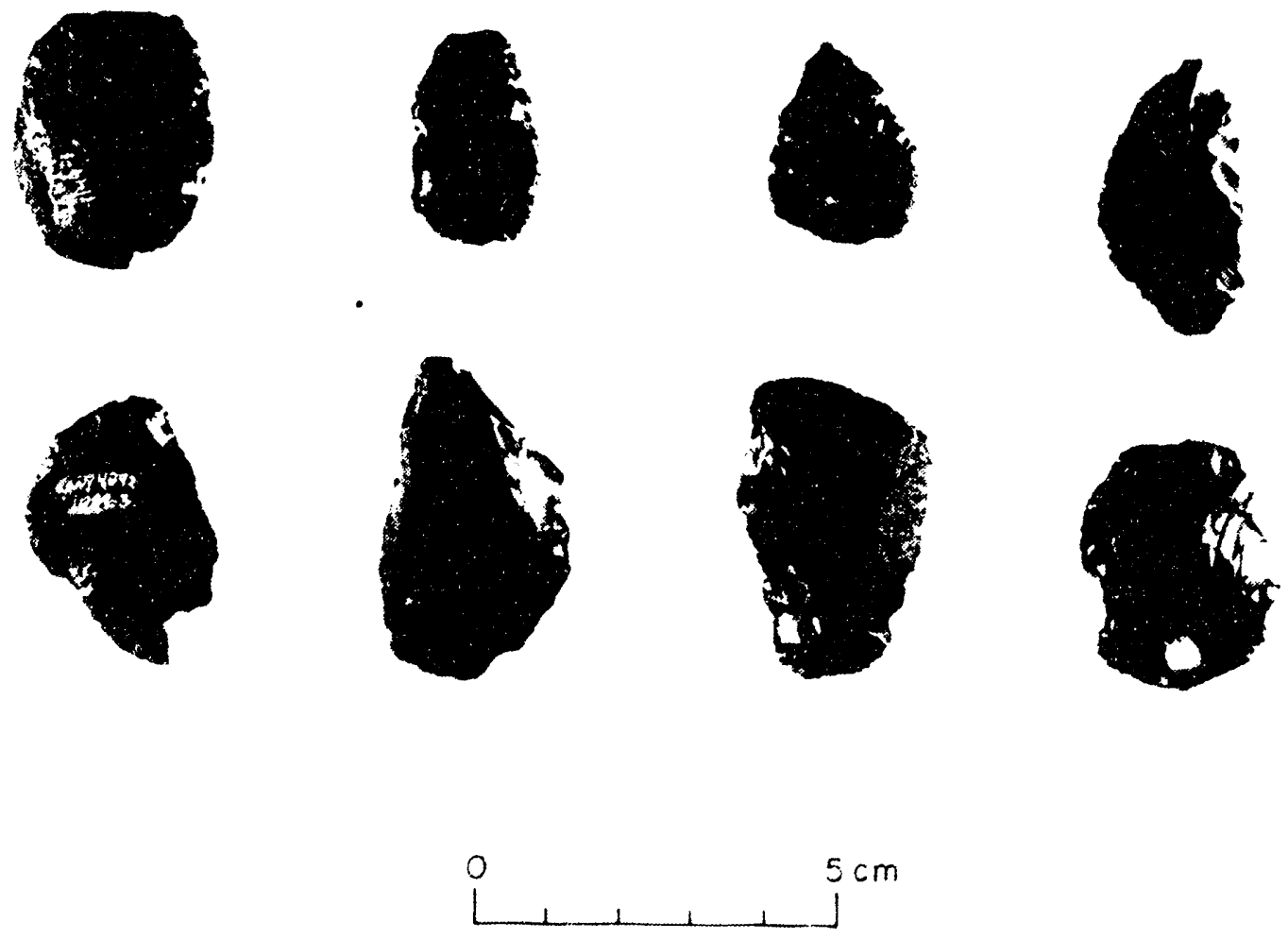

Figure 6-16. Obsidian intermediate stage bifaces (edged flake blanks) from 26Ny4892. Dorsal face. 

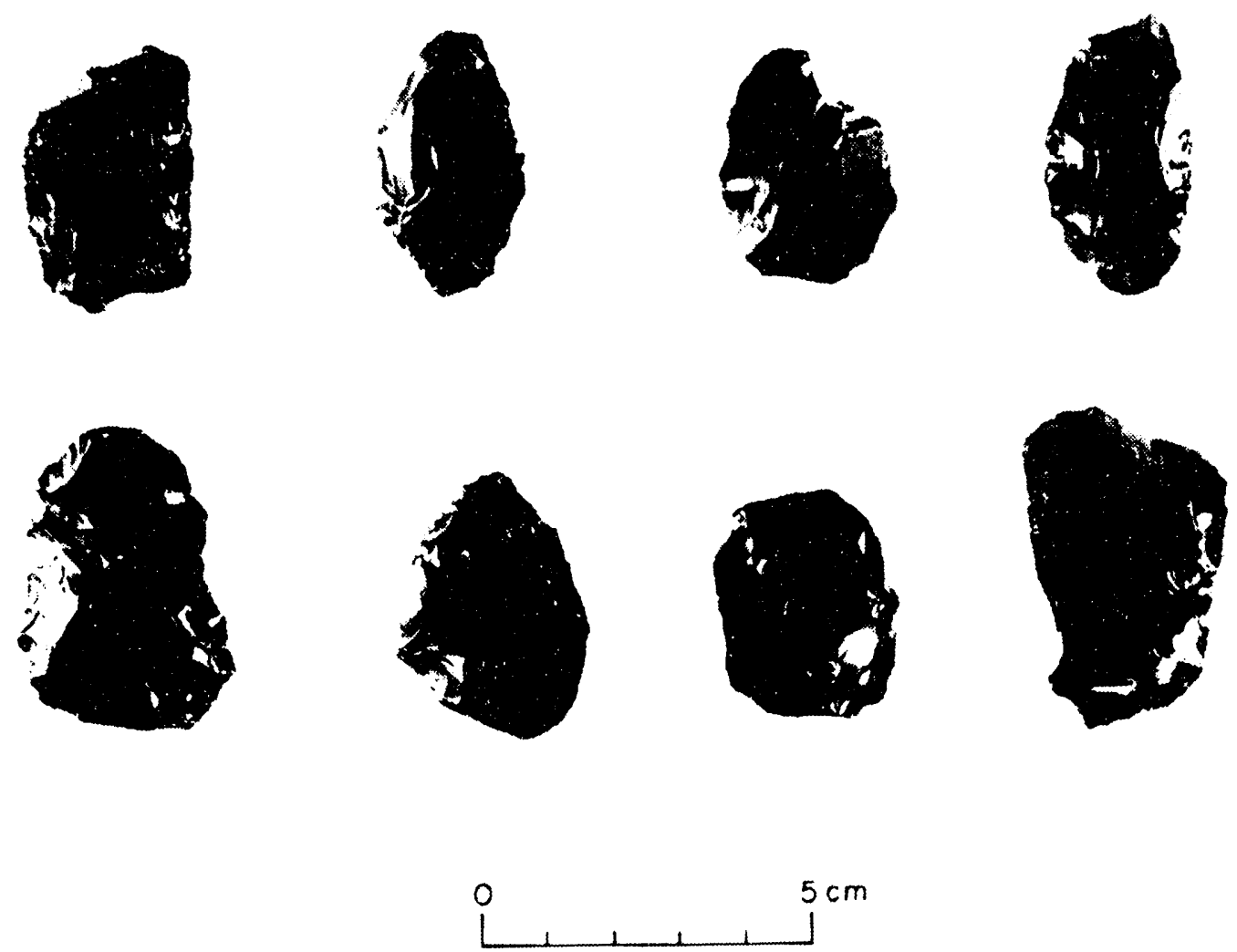

Figure 6-17. Obsidian early stage bifaces (indeterminate blanks) from $26 \mathrm{Ny} 4892$.

Table 6-15. Distribution of Thinning Index (weight/planview area) Statistics by Biface Type for Obsidian Bifaces from 26Ny4892.

\begin{tabular}{|c|c|c|c|c|c|c|c|}
\hline \multirow[b]{2}{*}{$\begin{array}{l}\text { Biface } \\
\text { Blank Type }\end{array}$} & \multirow[b]{2}{*}{$n$} & \multicolumn{6}{|c|}{ Thinning Index (grams/square $\mathrm{cm}$ ) } \\
\hline & & Mean & Dev & $\begin{array}{l}\text { Std } \\
\mathrm{CV}\end{array}$ & Median & $\begin{array}{l}\text { 75th } \\
\% \text { tile }\end{array}$ & $\begin{array}{l}25 \text { th } \\
\text { \%tile }\end{array}$ \\
\hline Nodule & 9 & 1.36 & 0.28 & 0.21 & 1.40 & 1.52 & 1.31 \\
\hline Indeterminate & 38 & 1.33 & 0.38 & 0.28 & 1.32 & 1.43 & 1.10 \\
\hline Split Nodule & 16 & 1.24 & 0.30 & 0.24 & 1.22 & 1.46 & 1.01 \\
\hline Edged Flake & 44 & 1.01 & 0.26 & 0.26 & 1.01 & 1.22 & 0.77 \\
\hline Late Stage & 25 & 0.82 & 0.20 & 0.24 & 0.81 & 0.94 & 0.69 \\
\hline Point & 3 & 0.71 & 0.18 & 0.25 & 0.69 & 0.72 & 0.60 \\
\hline
\end{tabular}

Key: $\quad n=$ number; Std Dev = standard deviation; $C V=$ coefficient of variation (std. dev. $\times 100 /$ mean) 
(mean $=1.36)$ and indeterminate blanks (mean $=1.33$ ), this may not be a significant difference. In fact, the good agreement between these two rankings is remarkable.

The thinning ratios listed in Table 6-17 also include cores and modified flake blanks. The characterization of cores as much thicker relative to bifaces is useful since it demonstrates that most cores represent a separate reduction trajectory based upon flake production rather than bifacial thinning. Since width and thickness measurements were also taken for flake tools, comparison of their thinning ratios relative to bifaces was considered worthwhile. The mean thinning ratio value for modified flake tools is placed between nodule blanks

TABLE 6-16. DISTRIBUTION OF THINNING RATIO (WIDTH/THICKNESS) STATISTICS FOR OBSIDIAN CORES AND BIFACES (BY TYPE) FROM $26 N Y 4892$.

\begin{tabular}{|c|c|c|c|c|c|c|c|}
\hline \multirow[b]{2}{*}{$\begin{array}{l}\text { Artifact } \\
\text { Type }\end{array}$} & \multirow[b]{2}{*}{$n$} & & \multicolumn{5}{|c|}{ Thinning Ratio (widtth/thickness) } \\
\hline & & Mean & $\begin{array}{l}\text { Std } \\
\text { Dev }\end{array}$ & $\mathrm{CV}$ & Median & $\begin{array}{l}\text { 75th } \\
\text { \%tile }\end{array}$ & $\begin{array}{l}\text { 25th } \\
\text { \%otile }\end{array}$ \\
\hline Cores (total) & 364 & 1.91 & 0.70 & 0.37 & 1.81 & 2.24 & 1.40 \\
\hline $\begin{array}{l}\text { Bifaces Indeter } \\
\text { minate Blanks }\end{array}$ & 38 & 2.31 & 0.59 & 0.26 & 2.30 & 2.70 & 2.09 \\
\hline $\begin{array}{l}\text { Bifaces } \\
\text { Nodule Blanks }\end{array}$ & 9 & 2.44 & 0.62 & 0.26 & 2.33 & 2.78 & 2.00 \\
\hline $\begin{array}{l}\text { Modified Flake } \\
\text { Tools (scrapers) }\end{array}$ & 35 & 2.64 & 0.72 & 0.27 & 2.67 & 3.00 & 2.00 \\
\hline $\begin{array}{l}\text { Bifaces Split } \\
\text { Nodule Blanks }\end{array}$ & 16 & 2.73 & 0.83 & 0.30 & 2.82 & 3.08 & 2.07 \\
\hline $\begin{array}{l}\text { Bifaces Edged } \\
\text { Flake Blanks }\end{array}$ & 44 & 3.23 & 1.08 & 0.34 & 3.00 & 3.73 & 2.45 \\
\hline $\begin{array}{l}\text { Late Stage } \\
\text { Bifaces }\end{array}$ & 25 & 3.59 & 0.82 & 0.23 & 3.60 & 4.00 & 3.00 \\
\hline $\begin{array}{l}\text { Projectile } \\
\text { Points }\end{array}$ & 19 & 4.19 & 0.82 & 0.20 & 4.25 & 4.80 & 3.57 \\
\hline
\end{tabular}

Key: $\quad n=$ number; Std Dev = siandard deviation; $C V=$ coefficient of variation (std. dev. $\times 100 /$ mean)

TABLE 6-17. ONE-WAY ANALYSIS OF VARIANCE BY THINNING INDEX WEIGHT/PLANVIEW AREA) AMONG OBSIDIAN BIFACE TYPES FROM $26 N Y 4892$.

\begin{tabular}{lrrrrr}
\hline $\begin{array}{l}\text { Source of } \\
\text { Variation }\end{array}$ & of & $\begin{array}{l}\text { Sum of } \\
\text { Squares }\end{array}$ & $\begin{array}{c}\text { Mean } \\
\text { Squares }\end{array}$ & F-Value & $p>F$ \\
\hline Between (Types) & 5 & 8.0003 & 1.6000 & 19.97 & $<0.001$ \\
Within (Types) & 145 & 11.6181 & 0.0801 & & \\
\hline
\end{tabular}

Key: $\quad d f=$ degrees of fresdom; $F$-Value = test of equal variance; $p>F=$ probability of finding a value greater than $F$. 
and split nodule blanks. This value suggests that some modified flake tools may have had some potential for recycling into the biface trajectory.

While edged flake blanks are similar to modified flake tools in that they are both manufactured on flakes, edged flake blanks have a much greater thinning ratio value. Although expended, modified, flake tools may have been suitable as blanks for biface production, manufacture of an edged flake blank provides much greater efficiency since less thinning is required. The difference in thinning ratio values of modified flake tools and edged flake blanks may reflect the selection of relatively thinner flake blanks for biface production while relatively thicker flake blanks were more suitable as flake tool preforms. To pursue models of flake production and selection parameters, thinning ratio values between edged flake blanks and waste flakes must be compared. Of course, the selective removal and reduction of some flake blanks complicates such modeling. In any case, these comparisons indicate some underlying constraints in the Timber Mountain obsidian nodule technology which serve to structure the assemblage. Size and relative thickness seem to be important determinants for successful biface reduction.

Despite the agreement in the ranking of the two thinning measures, there are other criteria that may be evaluated. In particular, minimiza- tion of the dispersion of values within each blank type is desirable. The coefficient of variation (CV) values provide a measure scaled to the mean and sample size of the relative percentage of variation. While CVs among the biface samples for both measures are similar, there is slightly more variance within the thinning ratio values. A one-way analysis of variance (ANOVA) was performed to determine whether variance was greater within or between biface blank types using each measure. Table 6-17 presents the ANOVA results for the obsidian biface thinning index c'ata. The ANOVA indicates that statistically significant differences exist between the types. These results imply that the biface classification that was used represents real differences between the types on the basis of a reduction trajectory defined by thinning index values.

The nature of these differences in mean thinning index values is examined in the Duncan's (e.g., Steel and Torrie 1960) multiplerange test results found in Table $6-18$. This means the comparison test (alpha $=.05$ ) produced three groupings with three corresponding order relationships. These groups are:

1) Early Stage Bifaces: nodule, split nodule, and indeterminate blank types;

2) Intermediate Stage Bifaces: edged flake blanks; and

3) Late Stage Bifaces: late stage bifaces and projectile points.

TABLE 6-18. DUNCAN'S MULTIPLE-RANGE TEST FOR MEANS OF THINNING INDEX VALUES AMONG OBSIDIAN BIFACE TYPES FROM $26 N Y 4892$.

\begin{tabular}{lccccc}
\hline $\begin{array}{l}\text { Biface } \\
\text { Blank Type }\end{array}$ & $\mathrm{n}$ & $\begin{array}{c}\text { Mean Thinning Index } \\
\text { (grams/sq. cm) }\end{array}$ & Grouping & \\
\hline Nodules & 9 & 1.36 & $\mathrm{~A}$ & \\
Indeterminate & 38 & 1.33 & $\mathrm{~A}$ & & \\
Split Nodules & 16 & 1.24 & $\mathrm{~A}$ & $\mathrm{~B}$ & \\
Edged Flakes & 44 & 1.01 & & & $\mathrm{C}$ \\
Late Stage & 25 & 0.82 & & $\mathrm{C}$ \\
Points & 19 & 0.71 & & \\
\hline
\end{tabular}

- Maans with tus sams latter ara not significantly diffarant (alpha = .05). 
The first grouping is represents early stage bifaces and includes nodule, split nodule, and indeterminate blank types. This early stage biface group has significantly larger thinning index values than edged flake blanks. Late stage bifaces and projectile points form the group with the smallest thinning index values and are thus considered to collectively represent a late stage biface group. Edged flake blanks have significantly larger thinning index values than the late stage bifaces and thus form an intermediate stage biface class. Overall, this classification is intuitively satistying and demonstrates the power of the thinning index technique for investigating biface reduction trajectories. The well-defined patterning in thinning index values is especially remarkable with an assemblage like 26 Ny 4892 where projectile point forms range from the large Great Basin Stemmed to the small Desert Side-notched series. However, differences in raw materials and reduction strategies do af- fect the range and distribution of thinning index values (cf. Johnson 1981; Amick 1985:144-145).

Another ANOVA was performed for the obsidian biface thinning ratio data. This test indicated that statistically significant differences exist between means at the .05 level. The results of this analysis are presented in Table 6-19.

Examination of the differences between mean thinning ratio is accomplished by the Duncan's multiple-range test (alpha $=.05$ ) presented in Table 6-20. These results indicate five groupings and 3 order relationships. The obsidian biface groupings are 1) indeterminate blanks and nodule blanks, 2) split nodule blanks, 3) edged flake blanks, 4) late stage blanks, and 5) projectile points. Recall that thinning ratio values increase through the biface reduction trajectory so that the mean relationships are reversed from the thinning index

TABLE 6-19. ONE-WAY ANALYSIS OF VARIANCE BY THINNING RATIO WIDTH/THICKNESS) AMONG OBSIDIAN BIFACE TYPES FROM $26 N Y 4892$.

\begin{tabular}{lrrrrr}
\hline $\begin{array}{l}\text { Source of } \\
\text { Variation }\end{array}$ & df & $\begin{array}{c}\text { Sum of } \\
\text { Squares }\end{array}$ & $\begin{array}{c}\text { Mean } \\
\text { Squares }\end{array}$ & F-Value & P $>$ F \\
\hline $\begin{array}{l}\text { Between (Types) } \\
\text { Within (Types) }\end{array}$ & 5 & 58.7935 & $\begin{array}{r}11.7587 \\
0.7259\end{array}$ & 16.20 & $<0.001$ \\
\hline
\end{tabular}

Key: $\quad d f=$ degrees of freedom; $F$-Value = test of equal variance; $p>F=$ probability of finding a value greater than $F$.

TABLE 6-20. DUNCAN'S MULTIPLE-RANGE TEST FOR MEANS OF THINNING RATIO VALUES AMONG OBSIDIAN BIFACE TYPES FROM $26 N Y 4892$.

\begin{tabular}{llcllll}
\hline $\begin{array}{l}\text { Biface } \\
\text { Blank Type }\end{array}$ & $n$ & $\begin{array}{l}\text { Mean Thinning Ratio } \\
\text { (width/thickness) }\end{array}$ & Grouping & \\
\hline Indeterminate & 38 & 2.31 & A & & \\
Nodules & 9 & 2.44 & A & & \\
Split Nodules & 16 & 2.73 & A & B & & \\
Edged Flakes & 44 & 3.23 & & B & C \\
Late Stage & 25 & 3.59 & & & D \\
Points & 19 & 4.19 & & & D
\end{tabular}

- Mearis with the same letter are not significantly different (alpha.05). 
perspective. The order relationships show that group 1 is significantly smaller than groups 3 , 4, and 5; groups 1, 2, and 3 are significantly smaller than groups 4 and 5 ; and group 4 is significantly smaller than group 5 . While the thinning ratio discriminates the groups at both ends of the trajectory, there is considerable overlap among the groups between them. Because of this overlap, the thinning ratio is considered to be much less precise than the thinning index for ordering biface trajectories. Although the thinning index yielded only three groupings, these groups are statistically distinct and have empirical merit.

Once bifaces are ordered into a reduction trajectory through the use of a measure like the thinning index, it is possible to determine the relative position of technological strategies within that trajectory. The exploitation of obsidian nodules at $26 \mathrm{Ny} 4892$ seems to have relied primarily on early stage, hard hammer percussion work. The shift to soft hammer work during the process of bifacial reduction reflects a fundamental technological shift from initial establishment of bifacial margins and rough shaping to thinning and final shaping. Therefore, determining the piacement of soft hammer percussion thinning within this sequence is basic to understanding the degree to which bifaces were reduced before leaving the quarry. Table 6-21 presents thinning index statistics for obsidian bifaces which exhibit soft hammer percussion versus those that do not.
Soft hammer (e.g., antler, bone, hardwood, limestone) percussion scars were identified on the basis of diffuse bulbs of percussion, expanding flakes, gently undulating ripples, and other criteria elegantly described by Crabtree (1970, 1972; see also Callahan 1979). As expected, soft hammer evidence is found on a minority (23.8\%) of the obsidian bifaces. The mean thinning index value for the appearance of soft hammer percussion is 0.85 which falls immediately before the mean of late stage bifaces at 0.82 . This position suggests that most biface reduction activities at $26 \mathrm{Ny} 4892$ were able to be conducted by hard hammer percussion until final shaping and thinning. Given the relative lack of obsidian BTFs from $26 \mathrm{Ny} 4892$, it appears that production of early stage bifaces and edged flake blanks by hard hammer percussion may have been the primary manufacturing objective at the quarry.

Further evidence for the association of soft hammer percussion with later stages of obsidian biface reduction is presented in Table 6-22. This table shows that statistically significant differences exist in the association of soft hammer percussion with different biface stages. There is a notable absence of soft hammer percussion in early stage bifaces and edged flakes while late stage bifaces exhibit a predominance of soft hammer evidence.

The predcrninance of early stage obsidian biface reduction activities at $26 \mathrm{Ny} 4892$ is demonstrated by the cortex cover observations

TABLE 6-21. DISTRIBUTION OF THINNING INDEX (WEIGHT/PLANVIEW AREA) STATISTICS BYINCIDENCE OF SOFT HAMMER PERCUSSION AMONG OBSIDIAN BIFACES FROM $26 N Y 4892$.

\begin{tabular}{|c|c|c|c|c|c|c|c|}
\hline \multirow[b]{2}{*}{$\begin{array}{l}\text { Soft Hammer } \\
\text { Percussion }\end{array}$} & \multirow[b]{2}{*}{$\mathbf{n}$} & \multicolumn{6}{|c|}{ Thinning Index (grams/square $\mathrm{cm}$ ) } \\
\hline & & Mean & $\begin{array}{l}\text { Std } \\
\text { Dev }\end{array}$ & $\mathrm{CV}$ & Median & $\begin{array}{l}\text { 75th } \\
\text { \%tile }\end{array}$ & $\begin{array}{l}25 \text { th } \\
\text { \%tile }\end{array}$ \\
\hline $\begin{array}{l}\text { Absent } \\
\text { Present }\end{array}$ & $\begin{array}{r}11 E \\
36\end{array}$ & $\begin{array}{l}1.15 \\
0.85\end{array}$ & $\begin{array}{l}0.36 \\
0.22\end{array}$ & $\begin{array}{l}0.32 \\
0.27\end{array}$ & $\begin{array}{l}1.12 \\
0.74\end{array}$ & $\begin{array}{l}1.37 \\
0.94\end{array}$ & $\begin{array}{l}0.89 \\
0.69\end{array}$ \\
\hline
\end{tabular}

Key: $\quad n=$ number, Sid Dev = standard deviation; $C v$ = coeninc 
TABLE 6-22. CROSS-TABULATION OF SOFT HAMMER PERCUSSION EVIDENCE AMONG OBSIDIAN BIFACE CLASSES AT 26 NY4892.

\begin{tabular}{lll}
\hline \multirow{2}{*}{$\begin{array}{ll}\text { Biface } \\
\text { Stage Class }\end{array}$} & \multicolumn{2}{l}{ Soft Hammer Percussion Scars } \\
\cline { 2 - 3 } & Absent & Present \\
\hline Early Stage (Nodule, Split & $O=61$ & $O=2$ \\
Nodule, and Indeterminate Blanks) & $E=45$ & $E=18$ \\
& $z=2.4$ & $z=3.8$ \\
& snc=0 & snc $=@$ \\
Edged Flake Blanks & $O=39$ & $O=5$ \\
& $E=31$ & $E=13$ \\
& $z=1.4$ & $z=2.1$ \\
Late Stage (Preforms and Points) & snc $=$. & snc $=0$ \\
& $O=15$ & $O=39$ \\
& $E=39$ & $E=15$ \\
& $z=3.8$ & $z=6.0$ \\
& snc $=@$ & snc $=@$ \\
\hline
\end{tabular}

Chi-square $=76.71, \mathrm{df}=2, \mathrm{p}<.000001$;

Key: $\quad O=$ observed; $E=$ expected; $z=$ cell residuals; $s n c=$ standard normal curve

TABLE 6-23. CORTEX COVER CATEGORIES AMONG OBSIDIAN BIFACES FROM $26 N Y 4892$ (WITH JOINT PERCENTAGES).

\begin{tabular}{lccc}
\hline & \multicolumn{3}{c}{ Reverse (Cortical) Face } \\
\cline { 2 - 4 } Obverse Face & No Cortex & $1-50 \%$ Cortex & $51-99 \%$ Cortex \\
\hline No Cortex & 70 & 55 & 14 \\
Jnt. & $46.4 \%$ & $36.4 \%$ & $9.3 \%$ \\
$1-50 \%$ Cortex & 8 & 4 \\
Jnt. & $5.3 \%$ & $2.6 \%$ \\
$51-99 \%$ Cortex & & 0 \\
Jnt. & & $0.0 \%$ \\
\hline
\end{tabular}

Key: Jnt. = overall percentage

summarized in Table 6-23. The percentage of cortex cover was estimated for each face, and these data are presented as a square matrix of paired category associations (since face is a random assignment). Over $50 \%(n=93)$ of the obsidian bifaces exhibit cortex on at least one face, and over $10 \%(n=18)$ of the obsidian bifaces exhibit more than $50 \%$ cortex on one iace. Since coriex ithe outer weathereod sur- face) is usually removed relatively early in the reduction sequence, the $26 \mathrm{Ny} 4892$ obsidian bifaces appear to include a significant proportion of early stage discards.

To this point, the biface analysis has focused on obsidian artifacts since obsidian nodule procurement and reduction appear to be very important technological activities at 
26Ny4892. However, the biface assemblage is comprised of a relatively high proportion on non obsidian artifacts $(10.1 \%, n=17)$. Table 6-24 presents the frequencies of each biface blank type by material type. While obsidian is represented in all biface classes, silicified tuff is present as a single early stage nodule blank. The general unsuitability of purple-brown silicified tuff for fine bifacial reduction is evident among other NTS collections (Pippin 1986; Henton and Pippin 1988). Nonetheless, the silicified tuff occurs as large cobbles and boul- ders that may be effectively reduced by bifacial core techniques.

The second and more significant pattern in Table 6-24 relates to vein opal and chert/chalcedony bifaces. All 13 of these material types are found as either later stage bifaces (Figures 6-18 and 6-19) or projectile points (e.g., Figure 6-20). Since there is a lack of evidence for significant late stage reduction of these materials in the debitage, it is clear that these bifaces were brought to $26 \mathrm{Ny} 4892$ in nearly finished or

TABLE 6-24. FREQUENCIES AND PERCENTAGES OF MATERIAL TYPES AMONG BIFACE CLASSES AT 26 NY4892.

\begin{tabular}{|c|c|c|c|c|}
\hline \multirow[b]{2}{*}{$\begin{array}{l}\text { Biface } \\
\text { Class }\end{array}$} & \multicolumn{4}{|c|}{ Material Type } \\
\hline & Obsidian & $\begin{array}{l}\text { Silicified } \\
\text { Tutf }\end{array}$ & $\begin{array}{l}\text { Vein } \\
\text { Opa! }\end{array}$ & $\begin{array}{c}\text { Chert/ } \\
\text { Chalcedony }\end{array}$ \\
\hline $\begin{array}{l}\text { Early Stage } \\
\text { Nodule Blank } \\
\text { C|R } \\
\text { R|C }\end{array}$ & $\begin{array}{l}9 \\
90.0 \% \\
6.0 \%\end{array}$ & $\begin{array}{c}1 \\
0.6 \%\end{array}$ & $\begin{array}{c}0 \\
10.0 \%\end{array}$ & 0 \\
\hline $\begin{array}{l}\text { Early Stage } \\
\text { Split Nodule } \\
\text { Blank } \\
\text { C|R } \\
\text { R|C }\end{array}$ & $\begin{array}{c}16 \\
100.0 \% \\
10.6 \%\end{array}$ & 0 & 0 & 0 \\
\hline $\begin{array}{l}\text { Early Stage } \\
\text { Indeterminare } \\
\text { Blank } \\
\text { C|R } \\
\text { R|C }\end{array}$ & $\begin{array}{c}38 \\
100.0 \% \\
25.2 \%\end{array}$ & 0 & 0 & 0 \\
\hline $\begin{array}{l}\text { Bifacially } \\
\text { Edged Flakes } \\
\text { C|R } \\
\text { R|C }\end{array}$ & $\begin{array}{c}44 \\
93.6 \% \\
29.1 \%\end{array}$ & 0 & 0 & 0 \\
\hline $\begin{array}{l}\text { Late Stage } \\
\text { Bifaces } \\
\text { C|R } \\
\text { R|C }\end{array}$ & $\begin{array}{c}25 \\
71.4 \% \\
16.6 \%\end{array}$ & 0 & $\begin{array}{c}7 \\
20.0 \% \\
77.8 \%\end{array}$ & $\begin{array}{c}3 \\
8.6 \% \\
42.9 \%\end{array}$ \\
\hline $\begin{array}{l}\text { Projectile } \\
\text { Points } \\
\text { C|R } \\
\text { R|C }\end{array}$ & $\begin{array}{c}19 \\
86.4 \% \\
12.6 \% \\
\end{array}$ & 0 & $\begin{array}{c}2 \\
9.1 \% \\
22.2 \% \\
\end{array}$ & $\begin{array}{c}1 \\
4.5 \% \\
14.3 \% \\
\end{array}$ \\
\hline Totals & $\begin{array}{c}151 \\
89.9 \%\end{array}$ & $\begin{array}{c}1 \\
0.6 \%\end{array}$ & $\begin{array}{c}9 \\
5.4 \%\end{array}$ & $\begin{array}{l}7 \\
4.2 \%\end{array}$ \\
\hline
\end{tabular}

Key: $\quad C \mid R=$ column given row; $R \mid C=$ row given column 


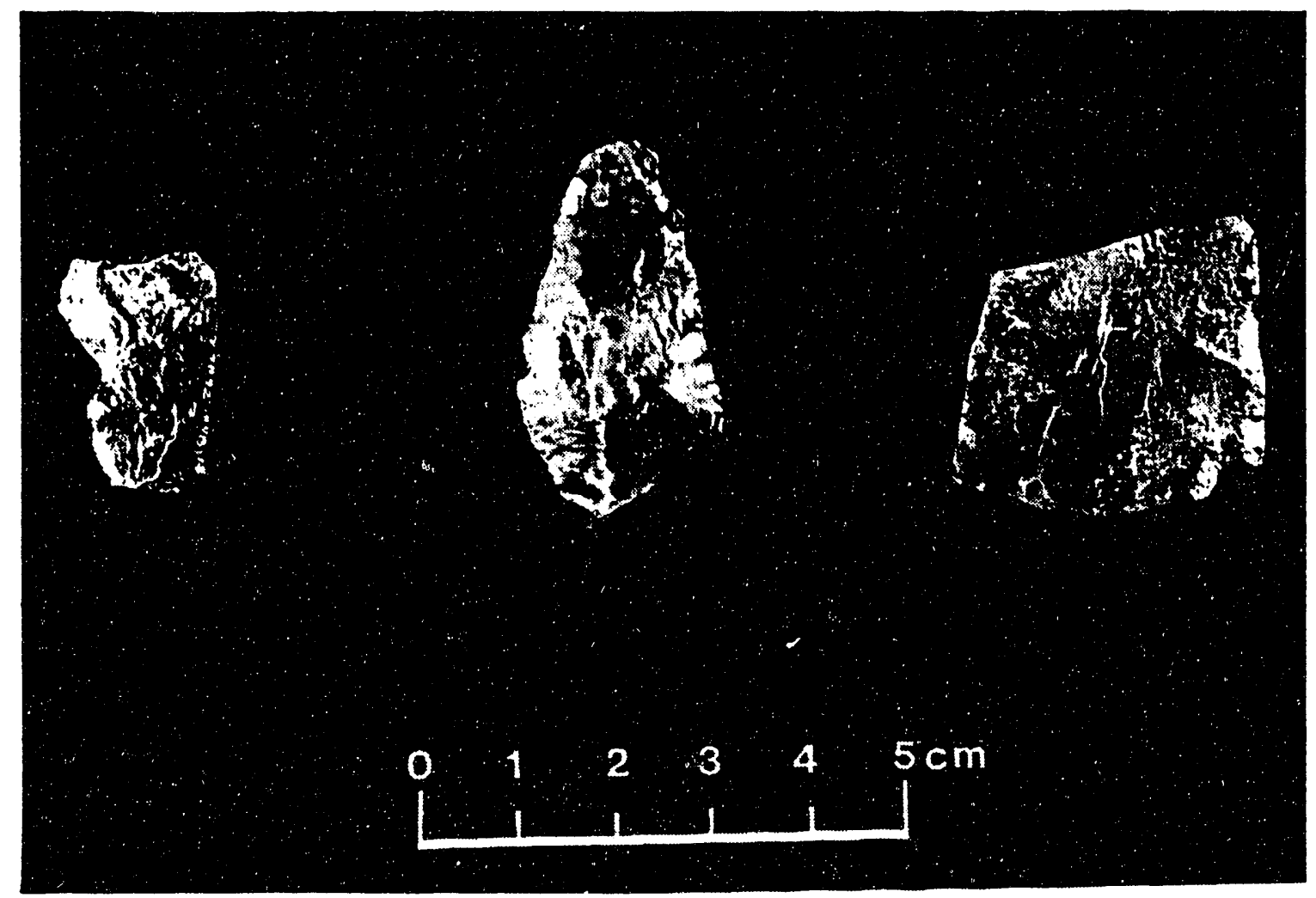

Figure 6-18. Chert/chalcedony late stage bifaces from 26 Ny4892.

exhausted form. Although vein opal may be procured within the region (e.g., Pahute Mesa), the occurrence of cherts/chalcedonies may suggest spatially extensive mobility systems were involved in the procurement of these materials. The relative lack of non obsidian materials among the bifaces at $26 \mathrm{Ny} 4892$ suggests that although this locality served as a significant resource for toolkit refurbishing, 1) few non obsidian materials were in the transported toolkit, 2) non obsidian articles within the transported toolkit were in finished or nearly finished form, and 3) non obsidian materials within the transported toolkit were not discarded unless broken or exhausted.

Table 6-25 presents thinning index statistics for the $26 \mathrm{Ny} 4892$ bifaces by material type. The single silicified tuff biface exhibits an extremely high value which supports the interpretation that it is a bifacial core. Obsidian bifaces are placed before the other non obsidian materials. This placement reflects the initial reduction and rather long trajectory of obsidian bi- face manufacture at $26 \mathrm{Ny} 4892$. The most interesting pattern in these values is the placement of vein opal below chert/chalcedony. Since the reduction sequence is monitored by decreasing thinning index values, the lowest thinning index values are found among exhausted bifaces. While sample sizes are small, it appears that vein opal bifaces are more reduced than chert/chalcedony bifaces.

Raw material procurement is typically em-

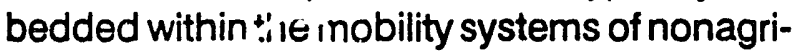
cultural foragers (Binford 1979). Therefore, the acquisition of toolstone may reflect the serial movement of groups across the regional landscape (Ingbar 1989). These factors indicate that, relative to reduction, vein opal was acquired prior to chert/chalcedony. The most likely source of these materials is in the adjacent upland areas. One of the vein opal bifaces resembles an Elko Series point, and the Rosegate Series points include one vein opal and one chert/chalcedony (jasper) specimen. This data may indicate that the use of vein opal 


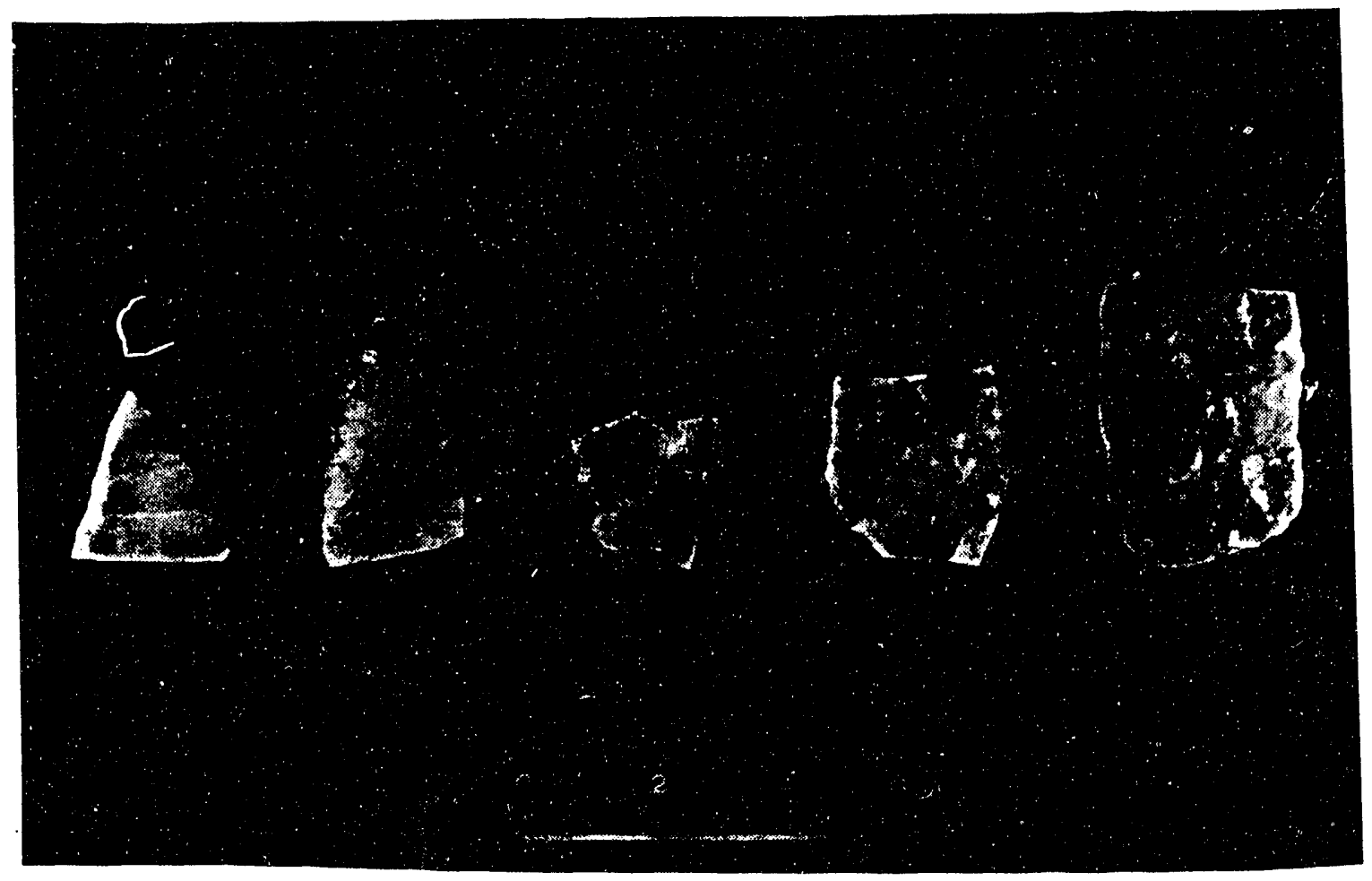

Figure 6-19. Vein opal late stage bifaces from 26 Ny4892.

and chert/chalcedony bifaces at $26 \mathrm{Ny} 4892$ is related to the temporal periods represented by these chronological markers (Thomas 1981; Holmer 1986; Jennings 1986; Pippin 1986:40-44). This limited evidence may suggest a sequence of regional landscape movement during these periods from vein opal source areas (e.g., Pahute Mesa) to chert/ chalcedony source areas (undetermined) to 26 Ny4892 where obsidian was procured. These data may support the widely held notion regarding increased use of the uplands following the mid-Holocene climatic optimum (e.g., Lyneis 1982b:177-178; Thomas 1982:165; Pippin 1986:45-53; cf. Thomas 1988:394-414). Of course, these inferences remain speculative due to the meager evidence and poor chronological control at $26 \mathrm{Ny} 4892$. In any case, the use of this type of analysis for investigating prehistoric mobility systems is worth pursuing with larger scale regional data (Johnson 1989; Henry 1989).

Table 6-26 presents cross tabulations of biface classes by categories of biface portion represented. Several patterns in this table relate to biface production and discard at 26Ny4892. The highest proportions of complete artifacts are found among the early stage bifaces, especially nodule and split nodule blanks where more than half are complete. The proportion of complete bifaces decreases in the indeterminate and edged flake blank categories. There is only a single late stage biface that is complete. The discard of complete early and intermediate stage bifaces may suggest that thinning efforts became ineffective as the piece became too small (relative to thickness) for suitable biface production. Edged flakes exhibit the highest proportion of indeter- 


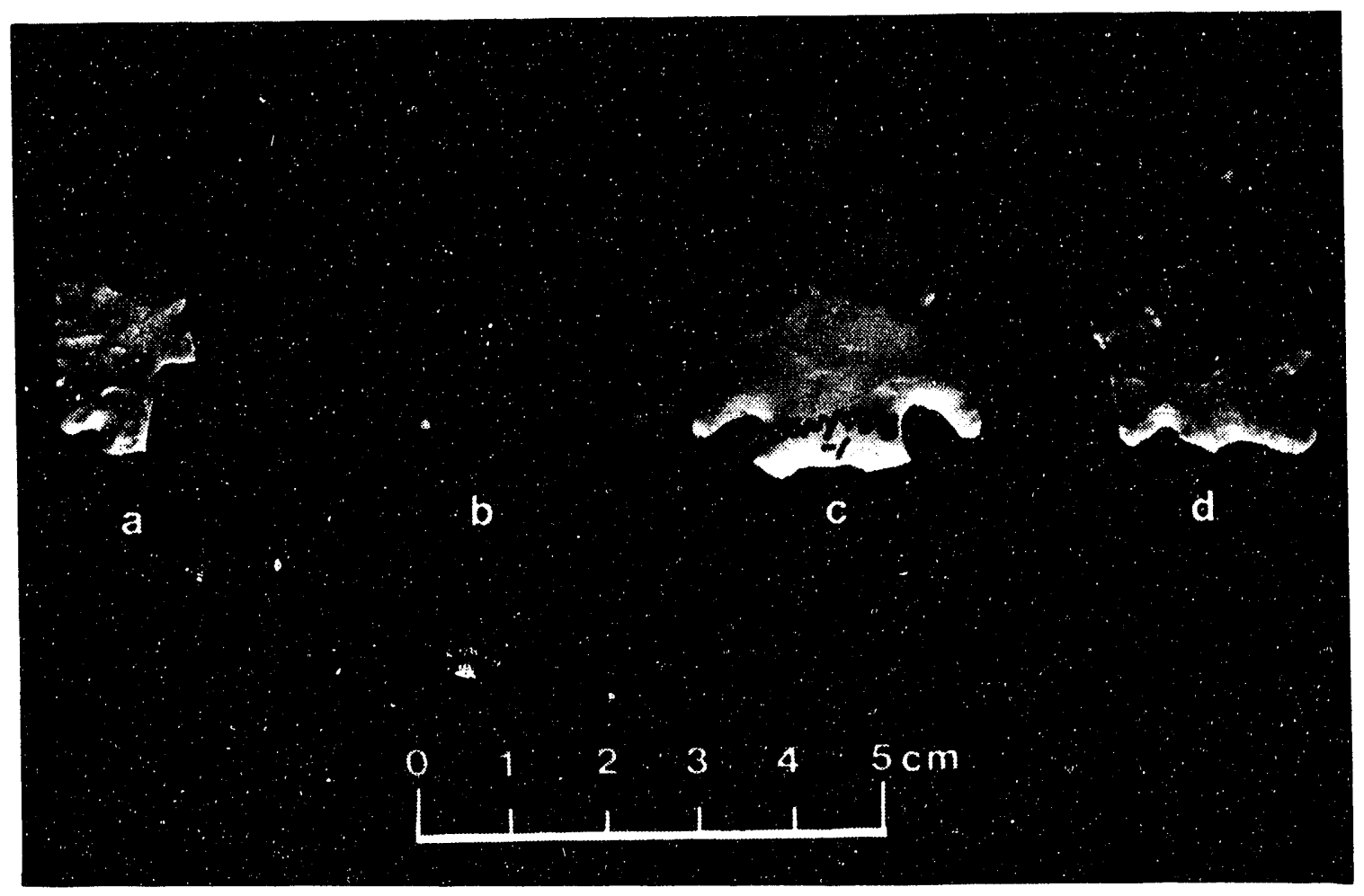

Figure 6-20. non obsidian projectile points. a) 26Ny4892-866-1, Rosegate. b) 26Ny4892-1709-1, Rosegate. c) 26Ny4893-1-1, Elko. d) 26Ny4892-1305-1, Elko.

TABLE 6-25. DISTRIBUTION OF THINNING INDEX (WEIGHT/PLANVIEW AREA) STATISTICS BY MATERIAL TYPES AMONG BIFACES FROM 26 NY4892.

\begin{tabular}{|c|c|c|c|c|c|c|c|}
\hline \multirow[b]{2}{*}{$\begin{array}{l}\text { Material } \\
\text { Type }\end{array}$} & \multicolumn{7}{|c|}{ Thinning Index (grams/square cm) } \\
\hline & $n$ & $\begin{array}{c}\text { Std } \\
\text { Mean }\end{array}$ & Dev & $\mathrm{CV}$ & Median & $\begin{array}{l}75 \text { th } \\
\% \text { tile }\end{array}$ & $\begin{array}{l}25 \text { th } \\
\% \text { tile }\end{array}$ \\
\hline Silicified Tuff & 1 & 2.43 & - & - & - & - & - \\
\hline Obsidian & 51 & 1.06 & 0.36 & 0.34 & 1.03 & $1.3 ?$ & 0.76 \\
\hline Chert/Chalcedony & 7 & 0.94 & 0.29 & 0.31 & 0.89 & 1.21 & 0.72 \\
\hline Vein Opal & 9 & 0.79 & 0.16 & 0.21 & 0.76 & 0.94 & 0.65 \\
\hline
\end{tabular}

Key: $\quad n=$ number; Std Dev = standard deviation; $C V=$ coefficient of variation (std. dev. $\times 100 /$ mean) 
minate fragments $(n=20,42.6 \%$ ) which probably relates to reduction stage. While edged flake blanks are considered to represent an intermediate stage of bifacial reduction, it appears that the proximal-versus-distal orientation of the blank remains undefined at this juncture. A decrease in the frequency of complete bifaces among the edged flakes indicates that most $(n=36,76.6 \%)$ are broken fragments in this category.

The proportion of specimens that can be oriented increases significantly among the late stage bifaces. The majority $(n=54,94.7 \%)$ of late stage bifaces and projectile points are classified as proximal, distal, or blade (medial/ lateral) fragments. This pattern indicates that during these stages bifacial reduction strategies focus on shaping as much as thinining.
Late stage bifaces exhibit a predominance $(n=16,45.7 \%)$ of medial/lateral fragments which suggests that work during this stage is primarily concerned with margin straightening and shaping. Presumably, final shaping for haft modification occurs at the end of this process.

Among the projectile points, the predominant category is proximal fragmer:s $(n=21$, $95.5 \%)$. The general absence of corresponding frequencies of distal fragments is noteworthy. Discard of projectile points at 26Ny4892 appears to have occurred after the tips were damaged and discarded elsewhere. This evidence implies that the projectile points at $26 \mathrm{Ny} 4892$ may have been discarded during retooling of arrows and dart shafts. For the most part, distal ends are assumed to be lost

TABLE 6-26. FREQUENCIES OF BIFACE FRAGMENT CATEGORIES BY BIFACE CLASSES FOR ALL MATERIAL TYPES (26NY4892).

\begin{tabular}{|c|c|c|c|c|c|c|}
\hline \multirow[b]{2}{*}{$\begin{array}{l}\text { Biface } \\
\text { Portion }\end{array}$} & \multicolumn{6}{|c|}{ Biface Classes } \\
\hline & $\begin{array}{l}\text { Nodule } \\
\text { Blank }\end{array}$ & $\begin{array}{l}\text { Split } \\
\text { Nodule } \\
\text { Blank }\end{array}$ & $\begin{array}{l}\text { Indeter } \\
\text { minate }\end{array}$ & $\begin{array}{l}\text { Edged } \\
\text { Flake }\end{array}$ & $\begin{array}{l}\text { Late } \\
\text { Stage }\end{array}$ & $\begin{array}{l}\text { Projectile } \\
\text { Point }\end{array}$ \\
\hline $\begin{array}{l}\text { Indeterminate } \\
\text { C } \mid R \\
R \mid C\end{array}$ & $\begin{array}{r}1 \\
3.4 \% \\
10.0 \%\end{array}$ & $\begin{array}{r}2 \\
6.9 \% \\
12.5 \%\end{array}$ & $\begin{array}{r}4 \\
13.8 \% \\
10.5 \%\end{array}$ & $\begin{array}{r}20 \\
69.0 \% \\
42.6 \%\end{array}$ & $\begin{array}{r}2 \\
6.9 \% \\
5.7 \%\end{array}$ & 0 \\
\hline $\begin{array}{c}\text { Complete } \\
\text { C } \mid R \\
\text { R|C }\end{array}$ & $\begin{array}{r}5 \\
13.2 \% \\
50.0 \%\end{array}$ & $\begin{array}{r}9 \\
23.7 \% \\
56.3 \%\end{array}$ & $\begin{array}{r}12 \\
31.6 \% \\
31.6 \%\end{array}$ & $\begin{array}{r}11 \\
28.9 \% \\
23.4 \%\end{array}$ & $\begin{array}{r}1 \\
2.6 \% \\
2.9 \%\end{array}$ & 0 \\
\hline $\begin{array}{c}\text { Proximal } \\
C \mid R \\
R \mid C\end{array}$ & $\begin{array}{r}1 \\
2.0 \% \\
10.0 \%\end{array}$ & $\begin{array}{r}3 \\
6.0 \% \\
18.8 \%\end{array}$ & $\begin{array}{r}8 \\
16.0 \% \\
21.1 \%\end{array}$ & $\begin{array}{r}9 \\
18.0 \% \\
19.1 \%\end{array}$ & $\begin{array}{r}8 \\
16.0 \% \\
22.9 \%\end{array}$ & $\begin{array}{r}21 \\
42.0 \% \\
95.5 \%\end{array}$ \\
\hline $\begin{array}{l}\text { Medial/Lateral } \\
\text { C } \mid R \\
R \mid C\end{array}$ & $\begin{array}{r}3 \\
10.0 \% \\
30.0 \%\end{array}$ & 0 & $\begin{array}{r}8 \\
26.7 \% \\
21.1 \%\end{array}$ & $\begin{array}{r}3 \\
10.0 \% \\
6.4 \%\end{array}$ & $\begin{array}{r}16 \\
53.3 \% \\
45.7 \%\end{array}$ & 0 \\
\hline $\begin{array}{r}\text { Distal } \\
C \mid R \\
R \mid C\end{array}$ & 0 & $\begin{array}{r}2 \\
9.5 \% \\
12.5 \%\end{array}$ & $\begin{array}{r}6 \\
28.6 \% \\
15.8 \%\end{array}$ & $\begin{array}{r}4 \\
19.0 \% \\
8.5 \%\end{array}$ & $\begin{array}{r}8 \\
38.1 \% \\
22.9 \%\end{array}$ & $\begin{array}{r}1 \\
4.8 \% \\
4.5 \%\end{array}$ \\
\hline
\end{tabular}

Key: $\quad C \mid R=$ column given row; $R \mid C=$ row given column 
at the place where they are damaged (e.g., on the hunt). The weapons which held the proximal fragments were probably transported until a suitable time for retooling occurred. Evidently, 26Ny4892 served as a locus for weapon retooling as well as a lithic quarry. Whether or not the quarrying and retooling activities at $26 \mathrm{Ny} 4892$ are functionally related is difficult to determine (cf. Gramly 1980). Based on ethnographic cases, Kuhn (1989) argues that retooling is a continuous, serial process among foragers while more logistically organized groups have periodic retooling at residential sites. As a consequence, the retooling evidence at 26 Ny4892 may have resulted from either residential, field camp, or limited task (quarrying) activities.

During the biface trajectory, it is expected that the frequency of breakage will increase. This breakage is first related to manufacturing causes, then use. A single break is often enough to interrupt the successful production of a biface. Table 6-27 presents the frequency of breakage among bifaces of different material types from $26 \mathrm{Ny} 4892$. Among obsidian bifaces, the majority of specimens in $=104$, $68.9 \%$ ) are either unbroken or broken on a single surface. This pattern undoubtedly reflects the predominance of early stage obsidian biface railures at $26 \mathrm{Ny} 4892$. However, there are obsidian bifaces with up to four broken surfaces in the collection. This pattern reflects the relatively long trajectory of the biface assemblage at $26 \mathrm{Ny} 4892$ although early stage manufacturing discards dominate. On the other hand, the majority of vein opal and chert/chalcedony bifaces $(n=10,62.5 \%)$ exhibit two or more discrete broken surfaces. Increased breakage is expected among late stage bifaces and projectile points because 1) thinner bifaces are prone to multiple remote fractures, 2) hafted projectiles are subject to compound impact shatter, and 3) exhausted bifaces may be intentionally broken to produce usable scraps of material.
The comparison of index values in Table 6-28 provides further evidence that more frequent breakage occurs later in the manufacture and use-life history of bifaces. The thinning indices and breakage frequencies demonstrate an inverse relationship. As bifaces become thinner, the frequency of breakage increases. This strong relationship suggests that counts of the number of discrete breaks may serve as a reliable and easily recorded measure of biface use-life history. Previous investigators have proposed similar approaches using a complex classification of biface breakage types (e.g., Johnson 1981; Amick 1985). Unfortunately, the relationship of these breakage types to technological processes remains unsubstantiated by experimental data, and the degreeof reliability for the typology of breakage types is uncertain. In fact, there are many breakage types which appear to intergrade in their morphological configuration. As a result, classification of biface breakage types is often very difficult for the uninitiated analyst. On the other hand, counting the number of discrete broken edges on a biface margin is relatively quick and easily learned.

\section{Projectile Points}

Twenty-two projectile point fragments were recovered from the $26 \mathrm{Ny} 4892$ surface coliections. Metric data for the $26 \mathrm{Ny} 4892$ projectile points are provided in Table 6-29. Definitions for most of these measurements are found in Lockett (1988:53). Neck width (NW) is equivalent to stem width (SW). The maximum shoulder width (MSW) is defined by Vaughan and Warren (1987:205) as the "[w]idth of blade at intersection of blade edge and shoulder." Stem thickness (ST) is defined as the thickest portion of the stem. Blade thickness (BT) is defined as the thickest portion of the blade. Measurements are only taken if specimens are complete or reworked across broken rrargins. If the measure is interrupted by even the slightest broken margin(s), the measure is not taken. Therefore, the absence of measure- 
TABLE 6-27. BIFACE BREAKAGE FREQUENCY ACROSS MATERIAL TYPES FROM 26 NY4892.

\begin{tabular}{|c|c|c|c|c|c|}
\hline \multirow{2}{*}{$\begin{array}{l}\text { Material } \\
\text { Type }\end{array}$} & \multirow[b]{2}{*}{0} & \multicolumn{4}{|c|}{ Number of Discrete Broken Surfaces } \\
\hline & & 1 & 2 & 3 & 4 \\
\hline $\begin{array}{l}\text { Obsidian } \\
C \mid R \\
R \mid C\end{array}$ & $\begin{array}{r}40 \\
26.5 \% \\
100.0 \%\end{array}$ & $\begin{array}{r}64 \\
42.4 \% \\
87.3 \%\end{array}$ & $\begin{array}{r}33 \\
21.9 \% \\
91.7 \%\end{array}$ & $\begin{array}{r}12 \\
7.9 \% \\
63.2 \%\end{array}$ & $\begin{array}{r}2 \\
1.3 \% \\
100.0 \%\end{array}$ \\
\hline $\begin{array}{l}\text { Sillicified Tuff } \\
\text { C|R } \\
\text { R|C }\end{array}$ & 0 & $\begin{array}{r}1 \\
100.0 \% \\
1.4 \%\end{array}$ & 0 & 0 & 0 \\
\hline $\begin{array}{c}\text { Vein Opal } \\
C \mid R \\
R \mid C\end{array}$ & 0 & $\begin{array}{r}3 \\
33.3 \% \\
4.2 \%\end{array}$ & $\begin{array}{r}1 \\
11.1 \% \\
2.8 \%\end{array}$ & $\begin{array}{r}5 \\
55.6 \% \\
26.3 \%\end{array}$ & 0 \\
\hline $\begin{array}{l}\text { Chert/Chalcedony } \\
\text { C|R } \\
R \mid C\end{array}$ & $y$ & $\begin{array}{r}3 \\
42.9 \% \\
4.2 \%\end{array}$ & $\begin{array}{r}2 \\
28.6 \% \\
5.6 \%\end{array}$ & $\begin{array}{r}2 \\
28.6 \% \\
10.5 \%\end{array}$ & 0 \\
\hline
\end{tabular}

Key: $\quad C \mid R=$ column given row; $R \mid C=$ row given column

TABLE 6-28. DISTRIBUTION OF THINNING INDEX (WEIGHT/PLANVIEW AREA) STATISTICS BY BREAKAGE GROUPS FOR BIFACES OF ALL MATERIAL TYPES FROM 26 NY4892.

\begin{tabular}{|c|c|c|c|c|c|c|c|}
\hline \multirow{2}{*}{$\begin{array}{l}\text { Number of } \\
\text { Discrete } \\
\text { Broken Edges }\end{array}$} & \multicolumn{7}{|c|}{ Thinning Index (grams/square cm) } \\
\hline & $n$ & Mean & $\begin{array}{l}\text { Std } \\
\text { Dev }\end{array}$ & $\mathrm{CV}$ & Median & $\begin{array}{l}\text { 75th } \\
\text { \%tile }\end{array}$ & $\begin{array}{l}\text { 25th } \\
\text { \%tile }\end{array}$ \\
\hline None (0) & 40 & 1.26 & 0.31 & 0.24 & 1.31 & 1.50 & 1.05 \\
\hline One (1) & 71 & 1.09 & 0.42 & 0.38 & 1.07 & 1.33 & 0.77 \\
\hline Two (2) & 36 & 0.91 & 0.25 & 0.27 & 0.89 & 1.05 & 0.69 \\
\hline Three (3) & 19 & 0.78 & 0.18 & 0.23 & 0.73 & 0.97 & 0.61 \\
\hline Four (4) & 2 & 0.76 & - & - & - & - & - \\
\hline
\end{tabular}

Key: $\quad n=$ number; Std Dev = standard deviation; $C V=$ coefficient of variation (std. dev. $\times 100 /$ mean) 
TABLE 6-29. METRIC ATTRIBUTES OF PROJECTILE POINTS FROM 26NY4892 (MM/G).

\begin{tabular}{lccccccccccc}
\hline Site & Ref & SpC & $L$ & $W$ & NW & BW & MSW & SL & BT & ST & $W T$ \\
\hline 4892 & 346 & 1 & 31.4 & - & 11.5 & 9.8 & - & 7.9 & 5.3 & 4.6 & 3.0 \\
4892 & 392 & 1 & - & 21.0 & 10.0 & - & 2.0 & - & 3.8 & 2.6 & 2.9 \\
4892 & 400 & 1 & 34.9 & - & 11.0 & - & - & - & 4.2 & 3.6 & 2.4 \\
4892 & 556 & 1 & - & - & - & - & - & - & 5.1 & 3.8 & 3.2 \\
4892 & 643 & 1 & - & - & - & 16.1 & - & - & - & 4.5 & 1.6 \\
4892 & 788 & 8 & - & - & - & 18.2 & - & - & - & 5.1 & 1.5 \\
4892 & 790 & 1 & 32.9 & - & 20.1 & 23.4 & - & 18.3 & 6.9 & 5.5 & 6.1 \\
4892 & 856 & 5 & - & - & 6.6 & - & - & 9.1 & 2.7 & 2.6 & 0.7 \\
4892 & 866 & 1 & - & - & - & - & - & 3.2 & 3.9 & 2.3 & 1.2 \\
4892 & 1018 & 1 & - & - & 12.4 & 12.1 & - & 13.8 & 6.1 & 4.7 & 3.7 \\
4892 & 1097 & 1 & - & 13.0 & - & - & - & 3.5 & 4.1 & 2.6 & 1.2 \\
4892 & 1106 & 1 & - & - & - & - & - & - & - & 5.2 & 0.9 \\
4892 & 1305 & 1 & - & - & 10.4 & - & - & 7.6 & 4.5 & 3.5 & 3.9 \\
4892 & 1533 & 1 & - & 25.8 & 20.9 & - & 22.5 & 14.3 & 8.8 & 7.8 & 6.2 \\
4892 & 1627 & 1 & - & - & 12.2 & 10.3 & - & - & 4.8 & 3.2 & 2.7 \\
4892 & 1678 & 1 & - & - & - & - & - & - & 4.1 & 2.6 & 2.1 \\
4892 & 1704 & 1 & - & - & - & - & - & - & 3.8 & 2.3 & 2.0 \\
4892 & 1708 & 1 & 31.8 & - & 8.5 & 8.0 & - & - & 4.5 & 4.0 & 2.3 \\
4892 & 1709 & 1 & - & - & 8.6 & 9.8 & - & 3.8 & 3.5 & 2.2 & 1.4 \\
4892 & 1720 & 1 & - & - & - & - & - & - & 4.6 & 3.4 & 1.3 \\
4892 & 1740 & 1 & - & 30.0 & 11.0 & - & 2.9 & - & 4.6 & 3.5 & 3.6 \\
4892 & 1750 & 1 & - & - & - & - & - & - & 4.8 & 4.6 & 2.3 \\
\hline
\end{tabular}

Key: $L=$ length; $W=$ width; $N W=$ neck width $B W=$ base width; $M S W=$ maximum shoulder width; $S L=s t e m$ length $B T=$ blade thickness; $T=$ stem thickness; $W T=$ weigh

ments provides some indication of the amount of breakage on the specimen. Proximal element and thickness measurements are nearly always possible. Weight is taken for all specimens regardless of breakage.

Classification of the projectile points generally follows Thomas (1981) although the points were not classified according to his key. Emphasis in the point type classification was placed on defining gerieral broad morphological groupings first, then comparing the classification to suggested regional typologies (e.g., Thomas 1981, 1983; Jennings 1986; Holmer 1986; Pippin 1986; Vaughan and Warren 1987). While it is obvious that considerable room for debate exists in Great Basin projectile point typology (e.g., Beck 1988), the data provided by a handful of fragmentary points from a desert pavement surface in Southern Nevada are unlikely to make a significant contribution to the resolution of these issues. Therefore, this analysis is descriptive with emphasis on temporal and functional parameters. Point descriptions are listed in reverse chronological order based upon common regional typologies. Details regarding the obsidian hydration measurements are found in the Chapter 9 . The hydration rim data show generally good agree. ment with expected chronological relationships. 
Ixpe: Desert Side-notched Series

Number of Specimens: 1

Reference Number: 856-1

Figure: 6-21

Material: Obsidian

Hydration Rim: mean 2.38 microns

Comments: This specimen was snapped on the distal and proximal ends. In addition, one side is weathered. Desert Side-notched points are arrow tips and represent the youngest recognized point type in the Great Basin (Baumhoff and Byrne 1959).

\section{Iype: Rosegate Series}

Number of Specimens: 6

Reference Numbers: 392-1, 400-1, 866-1, $1704-1,1708-1,1709-1$

Figures: $6-20$ and 6-21

Material: Obsidian $(n=4)$, yellow jasper $(n=1)$, chert $(n=1)$

Hydration Rims: mean 2.64 microns, range 2.17-3.25 microns

Comments: These small points resemble the Rose Spring point type (Lanning 1963) and are probably arrow tips. All of the specimens have distal snaps, and five have proximal snaps. The jasper specimen is unifacially resharpened on one blade margin. An obsidian specimen is serrated on one margin and unifacially damaged on the other. Three specimens were manufactured on flake blanks, and three are weathered. The Rosegate Series is considered to be a late Holocene point type.

Iype: Gatecliff Split Stem Series

Number of Specimens: 2

Reference Numbers: 556-1, 1740-1

Figures: 6-21 and 6-28 (line drawing of 556-1)

Material: Obsidian

Hydration Rim: mean 3.18 microns (556-1 only)

Comments: Both are comparable to the Gatecliff Split Stem type (Thomas 1983). These two specimens have distal snaps and proximal damage and are weathered. Specimen 556-1 exhibits considerable reworking on both faces. A small relict of an older weathered artifact surface is evident on one face. It is likely that Gatecliff points may be atlatl dart points. Gatecliff Series points are middle to late Holocene-period artifacts. Although specimen 1740-1 had no visible hydration rim, it exhibited a dark brown (ignimbrite?) appearance in thin section (Janis Klimowicz, personal communication 1990).

Iype: Possible Gatecliff Contracting Stem

Number of Specimens: 1

Reference Number: 1018-1

Figure: 6-22

Material: Obsidian

Hydration Rim: mean 3.0 microns

Comments: This stem fragment was snapped on the blade and shoulders. The stem is tapered relatively long and narrow and exhibits broad deep flake scars with only a few pressure flake removals. Crude workmanship characterizes this specimen which is thick and difficult to classify but exhibits some resemblance to the Gatecliff Contracting Stem type (Thomas 1983). However, this artifact appears to have been reworked by beveled retouch on what appears to be a thick core or flake. It may represent a manufacturing reject, practice piece, or other formal tool type (e.g., perforator ?). This specimen exhibited a dark brown appearance in thin section (Janis Klimowicz, personal communication 1990).

Type: Elko Series

Number of Specimens: 1

Reference Number: 1305-1

Figure: $6-20$

Material: Vein opal

Comments: This specimen exhibits distal and proximal snaps and can be referred to as the Elko type (O'Connell 1967). Elko points are probably dart points which date to the middle and late Holocene.

Iype: Possible Medium Side-notched Series

Number of Specimens: 1

Reference Number: $1750-1$

Material: Obsidian 
Hydration Rim: mean 3.0 microns

Comments: This specimen is fragmentary with severe breakage on the proximal end. The blade appears to have been resharpened, and a shallow side notch is evident on one blade margin. The hydration rim mean is 3.0 microns which suggests a middle to late Holocene age. This point may be related to the small sidenotched series described by Holmer (1986:107) that precedes the Desert Sidenotched type.

\section{Iype: Humboldt Series}

Number of Specimens: 1

Reference Number: 1097-1

Figure: 6-23

Material: Obsidian

Hydration Rim: mean 6.67 microns

Comments: There is minor impact damage on tip and breakage on the proximal end, and the specimen is weathered. This artifact is relatively small. An estimate of length provides a measurement of $23.6 \mathrm{~mm}$, and neck width is about $11.6 \mathrm{~mm}$. These estimates in concert with the width and thickness measurements allow this point to be classified using the discriminant functions for determining dart points from arrow points provided by Thomas (1978). These discriminant functions were developed from measurements of 142 stone-tipped arrows and dart shafts and provided about $86 \%$ correct classification. The classification values for this Humboldt point strongly indicate that it is an arrow tip. However, as noted by Thomas (1978:461-466), considerable variation is theoretically possible in stone-tipped weaponny.

Humboldt points are considered to reflect a broad chronological range throughout the early and middle Holocene (Jennings 1986). The obsidian hydration rim value for specimen 1.:7-1 supports an early-middle Holocene date. If at least some of these specimens are arrow tips, then the strategy of bow hunting may hold greater antiquity than previously credited for the prehistoric peoples of the Great Basin (Webster 1980) and the New
World in general. Regardless of the antiquity of bow hunting, it does not appear to have become the predominant hunting strategy in North America until about 1500 years ago.

Iype: Pinto Series

Number of Specimens: 1

Reference Number: 1533-1

Figure: 6-23

Material: Obsidian

Hydration Rim: mean 6.98 microns

Comments: This specimen exhibits a snapped tip that was reworked and then battered. The blade is beveled on both margins, and both faces of the artifact are weathered. Pinto points are early Holocene dart points which probably served as generalized hafted knives. These points are often characterized by extensive blade reworking, often by beveling, suggesting that they may have served a different functional anci technological role than earlier and later points.

Ixpe: Great Basin Stemmed Series

Number of Specimens: 2

Reference Number: 788-1, 790-1

Figure: 6-22

Material: Obsidian

Hydration Rims: mean 7.58 microns, range

6.98-8.17 microns

Comments: Specimen $788-8$ is a basal fragment. Specimen $790-1$ has been extensively reworked on both the distal and proximal ends. The blade has been reworked and then battered and burinated. The proximal end was reworked after basal grinding. The hydration rim measurement for this specimen is $8.17, \mathrm{i}$ crons, and, in thin section, this piece exhibited a very dark brown appearance (Janis Klimowicz, personal communication 1990). Both specimens are weathered on both faces. The Great Basin Stemmed (GBS) Series, like the Pinto Series, is typified by a long use-life history with extensive reworking. GBS points are believed to date to the late Pleistocene and eariy Holocene.

Reworked blades within the GBS Series have a distinctive character which has been 
noted by Tuohy (1969). GBS blade margins are often rejuvenated by a variety of techniques which include beveling, burination, and distal impact. These techniques help maintain an acute blade edge. Unifacial beveling alone eventually results in a long narrow blade with a wide blade edge angle (e.g., Hoffman 1985). Rejuvenation of the GBS points relied on broad, flat, thinning flake removal which allowed the entire blade to be whittled away. In many cases, the long broad stems of the GBS points also exhibit grinding, damage, and reworking (for rehafting or scraper use). The extensive reworking of GBS points reflects a different technological role for these tools compared to later period points. GBS points probably served as generalized cutting/scraping tools with a considerable use-life. This form of technology is often felt to reflect a highly mobile lifestyle where energy investment is placed in increasing tool use-life rather than frequent procurement.

\section{Iype: Indeterminate Bifurcate Base}

Number of Specimens: 4

Reference Number: 346-1, 1106-1, 1627-1, 1678-1

Figure: 6-23

Material: Obsidian

Hydration Rims: mean 4.03 microns, range $1.6-7.13$ microns

Comments: This category accommodates the Gatecliff Split Stem and Pinto series that were difficult to distinguish. Potential solutions to this typological problem have been argued by Warren (1980; Vaughan and Warreri 1987) and Thomas (1981:22). Specimen 1627-1 is similar to the Gatecliff Split Stem type but cannot confidently be assigned to that type because of breakage. Although it yielded a hydration rim mean of 1.6 microns, weathering may have altered the hydration rim. In addition, this piece may have been reworked at a later time as evidenced by a difference in the character of finishing flake scars.
Specimens $346-1,1106-1$, and 1678-1 seem more similar to the Pinto Series. Reference 346-1 appears to have been resharpened. One shoulder was broken by postdepositional trauma after the artifact became weathered. The hydration rim mean for 346-1 is 7.13 microns which supports a chroriviogical affinity with the Pinto Series.

Specimen $1106-1$ is a bifurcate stem snapped from the blade; a lateral hinge fracture is found on one ear. The hydration rim mean for $1106-1$ is 3.68 . The blade on specimen 1678-1 has been reworked and then battered. One bifurcate ear has been snapped off, and the opposite shoulder is damaged. The hydration rim mean for this piece is $3.7 \mathrm{mi}$ crons, but the artifact appears weathered. Combined hydration rim data for these two artifacts suggests chronological placement as early for the Gatecliff Series or late for the Pinto Series. Overall, the wide range of $r$, dration rim values for these four points reflects the typological problems in distinguishing bifurcate-based points in Southern Nevada.

Iype: Point Fragments of Indeterminate Type

Number of Specimens: 2

Reference Numbers: 643-1, 1720-1

Figure: 6-22

\section{Material: Obsidian}

Comments: These points are too fragmentary to type. Specimen $643-1$ is a broad blade or stem fragment that is not ground on the margins. It yielded a mean hydration rim thickness of 4.15 microns but is weathered on both faces. Specimen $1720-1$ is a midsection tragment. Orie remaining notch suggests the artifact may have been corner-notched. The hydration rim value of 2.7 microns indicates that 1720-1 may be an Elko or Rosegate series point. This specimen also exhibited a dark brown appearance in thin section (Janis Klimowicz, personal communication 1990). One face is weathered.). 


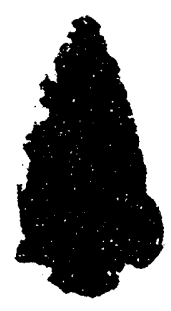

a

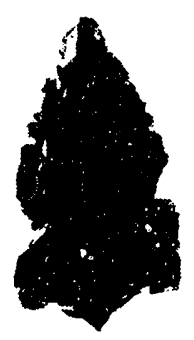

e

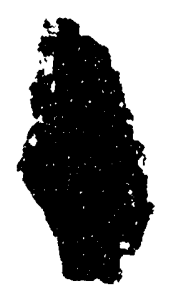

b

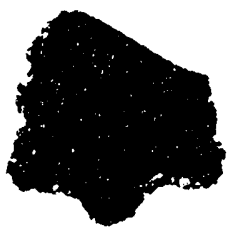

f

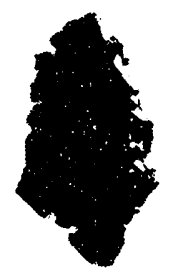

c

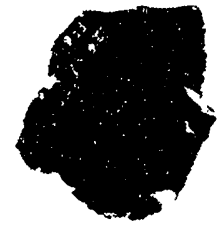

g

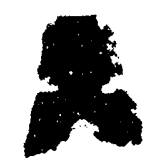

d

0 $5 \mathrm{~cm}$

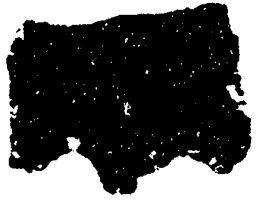

h

Figure 6-21. Small obsidian projectile points.

a) 26Ny4892-400-1. Rosegate; b) 26Ny4892-1704-1, Rosegate; c) 26Ny4892-1708-1, Rosegate: d! 26Ny4892-856-1. Desert Side-notched; e) 26Ny4892-392-1. Rosegate; f) 26Ny4875-1-1. Gatecliff; g) 26 Ny4892-556-1. Gatecliff; and h) 26Ny4892-1740-1, Gatecliff.

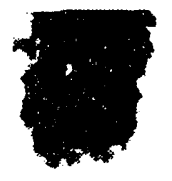

a

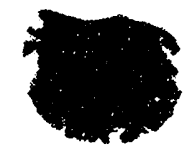

b
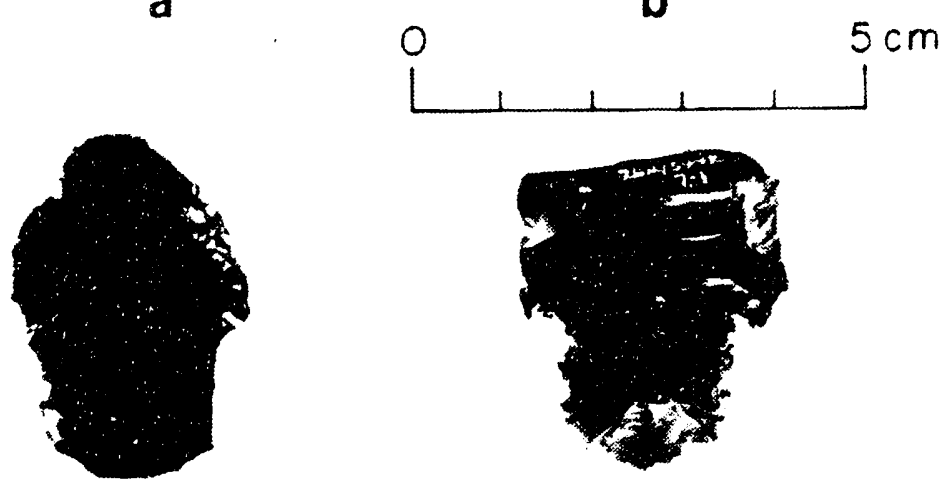

d

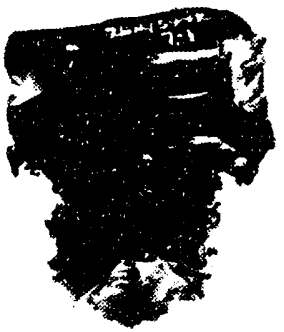

e

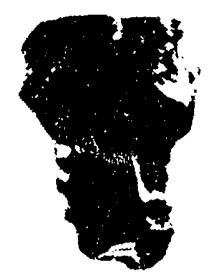

C

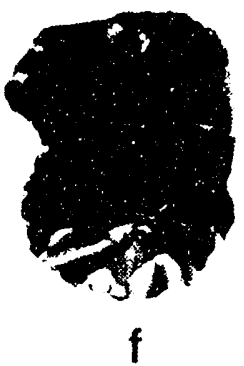

Figure 6-22. Stemmed obsidian projectile points.

a) 26Ny4892-643-1, indeterminate fragment: b) $26 \mathrm{Ny} 4892-788-8$. Great Basin Stemmed; c) 26Ny4892-1018-1. Possible Gatecliff Constricted Stem; d) 26Ny5431-1-1. Great Basin Stemmed; e) 26Ny4892-790-1. Great Basin Stemmed; f) 26Ny5442-7-1. Great Basin Stemmed. 


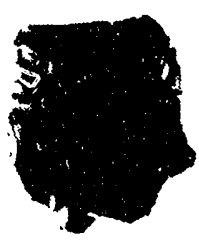

a

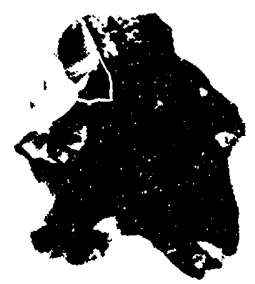

d

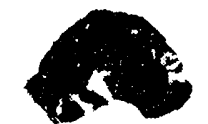

b

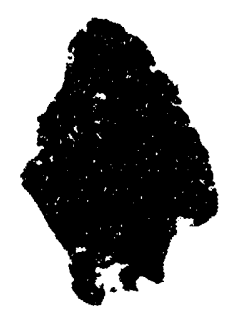

e

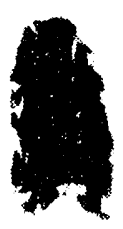

C

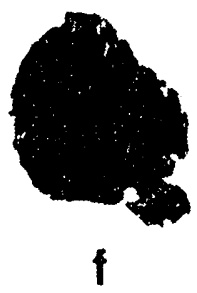

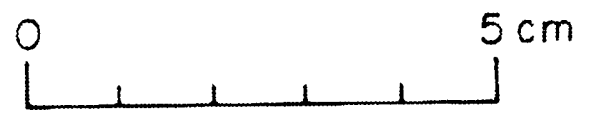

Figure 6-23. Bifurcate-based obsidian projectile points.

a) 26Ny4892-1627-1, indeterminate bifurcate base; b) 26Ny4892-1106-1, indeterminate bifurcate base; c) 26 Ny4892-1097-1. Humboldt; d) 26Ny4892-1533-1. Pinto; e) 26Ny4892-346-1. indeterminate bifucate base: f) $26 \mathrm{Ny} 4892-1678-1$, indeteminate bifurcate base.

\section{Nonchipped-Stone Artifacts Hammerstones}

One hammerstone was recovered from the surface of grid unit $1010 \mathrm{~N} 1120 \mathrm{E}$ at 26Ny4892. This quartzite hammer weighs $379.2 \mathrm{~g}$ and exhibits extensive battering at one end and along must ridges and high points. The only piece of quartzite recovered at the site was procured elsewhere for specific use as a hammerstone before it was deposited at 26Ny4892. This hammerstone appears to have been manufactured on a subconical or multidirectional core. However, this core reduction may simply have been a means of shaping the hammerstone to a desirable size and shape. Some relatively large flakes were removed by battering. The removal of these flakes may have been either unintentional spalls resulting from hammerstone use or intentional efforts to produce usable flakes and/ or rejuvenate the exhausted edges of the hammerstone. Its size suggests that it may have been useful in small obsidian nodule splitting, large silicified tuff cobble reduction, groundstone shaping, or vegetaibie material processing. Given the abundance of chipping debris at $26 \mathrm{Ny} 4892$, the lack of percussion instruments like hammerstones is perplexing. However, other quarry localities like the Bass Site in southwest Wisconsin (Stoltman, Behm, and Palmer 1094) and the Knife River Flint Quarries in North Dakota (Ahler 1986; Ahler and Christensen 1983) exhibit similar low frequencies $(<.02 \%$ of the total assemblage) of hammerstones. Evidently, hammerstones were carried to and from 26Ny4892. The apparent need to transport hammerstones to and from the quarry may have incurred greater costs to the use of this place by prehistoric hunter-gatherers 


\section{Groundstone}

Three groundstone artifacts were recovered from the surface collections at 26Ny4892. All are millingstones, but two of the three are not portable. The two large millingstones are manufactured from available purple-brown silicified tuff boulders. The larger of these two is a coarse textured rock while the smaller is a fine textured rock. The third and millingstone $(2.2 \mathrm{~kg})$ is manufactured on a coarse textured, flow banded slab of welded tuff (Figure 6-24). All three of the millingstones exhibit a small oval area about $25-b y-12 \mathrm{~cm}$ that is slightly depressed $2-3 \mathrm{~cm}$ due to grinding. Table 6-30 presents descriptive provenience and size data for these millingstones.

The millingstcines were probably used to grind seeds from local plants. At this elevation, it is most likely that seed gathering was limited to seasonal (spring) availability of Indian rice grass (Oryzopis hymenoides) and chia (Salvia columbariae var. columbariae) (Pippin and Davis 1988:9). The occurrence of these millingstones at $26 \mathrm{Ny} 4892$ suggests that although quarrying of obsidian was practiced extensively, some limited domestic activities may also have occurred at this location. The two large millingstones were obviously used in an ad hoc manner and not intended to be transported. The third $(2.2 \mathrm{~kg})$ was probably portable and may have been brought into the site.

The distinction between portable and nonportable millingstones deserves greater attention in the archaeological record of Southern Nevada. It probably relates directly to mobility parameters and settlement-subsistence organizational strategies. Although the evidence is certainly slim at $26 \mathrm{Ny} 4892$, it appears that seed grinding was not a planned activity at this locality. Some of the seed grinding that occurred required the expedient use of two local boulders, implying that portable millingstones may not have been available. The paucity of millingstones at $26 N y, 4892$ is clear when compared to the archaeological record of Pahute
Mesa, where $10 \%$ of the artifact assemblage is comprised of millingstones (Pippin 1986:141

\section{Chronology and Occupational History}

Since projectile points are generally considered to be chronological markers, the frequency of these types may indicate something about the occupational history at $26 \mathrm{Ny} 4892$. The proportion of different chronological groupings of the points is presented in Table 6-31. These groupings are based upon general seriation models of these point styles in conjunction with the obsidian hydration data reported below and by Klimowicz (Chapter 9). Although these patterns are extremely tentative, there does seem to be a trend for increasing deposition of points at $26 \mathrm{Ny} 4892$ through time. In addition, the late Holocene group probably represents a much shorter interval of time than the preceding two groups. These frequencies, when combined with the hydration rim analysis, suggest that the amount of prehistoric activity at $26 \mathrm{Ny} 4892$ increased during the late Holocene.

The specific relationship of spatia! association betwesn the projectile points and debris at $26 \mathrm{Ny} 4892$ is probably not isomorphic. For example, a sample of 60 flakes was taken from three spatially discrete grid units each about 200-300 m apart. These three grid units were selected, in part, because there appeared to be gross spatial associations of temporally restricted point types within these areas. Howev$e r$, the obsidian hydration results from these different grid areas (Chapter 9) do not correspond to the chronological association inferred from the projectile points. The general lack of spatial correspondence between discarded projectile points and debris has beei suggested by a number of "nonsite" archaeological studies (e.g., Thomas 1975, 1988:415-448; Camilli 1983; Jones 1984; Ebert 1986; Turner and Klippel 1989). It seems reasonable to assume that the quarry waste at 26 Ny4892 probably resulted from a different process than tool discard patterns. In effect, the distribution of projectile points and quarry 


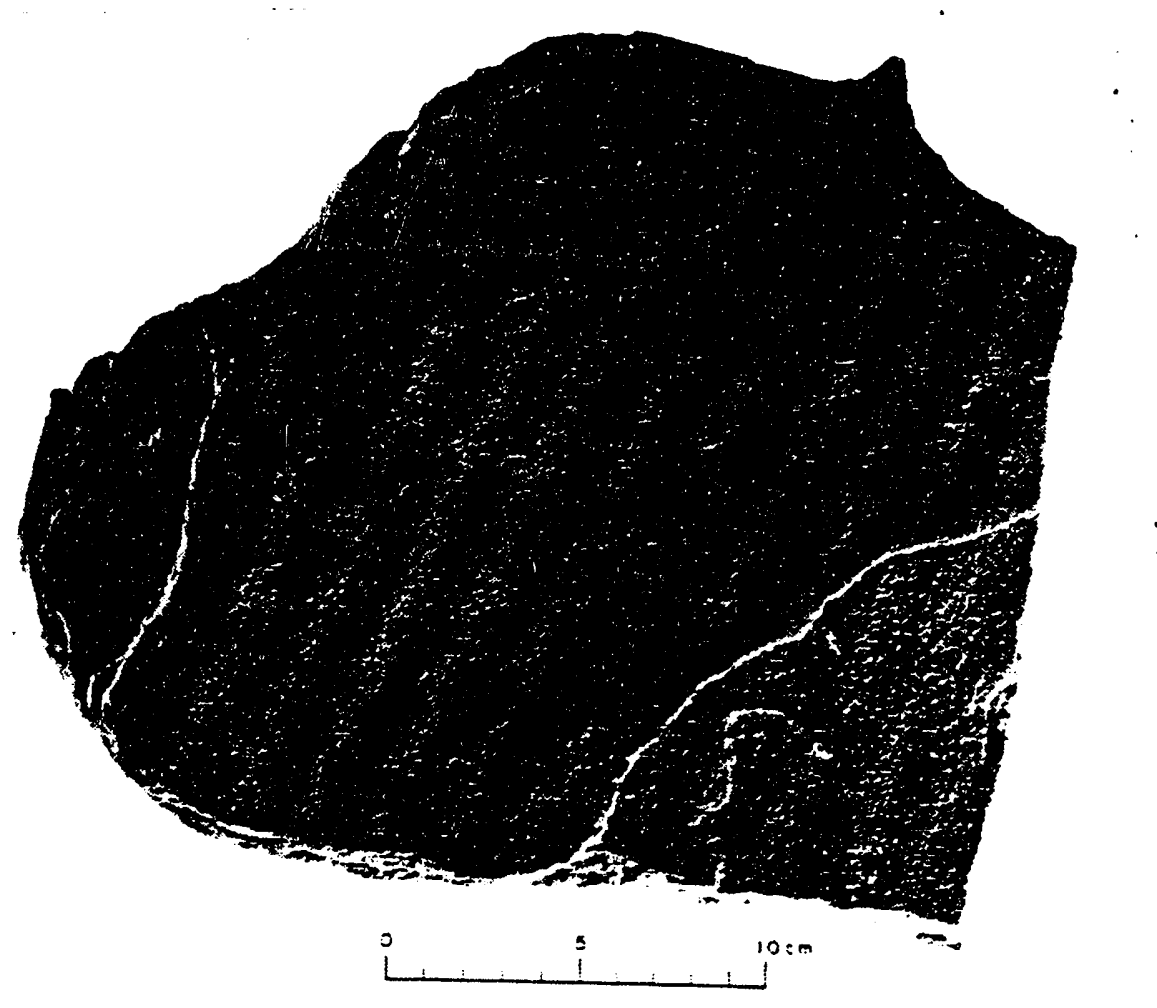

Figure 6-24. Slab millingstone from 935N 975E at $26 \mathrm{Ny} 4892$.

TABLE 6-30. DESCRIPTIONS OF MILLINGSTONES FROM 26 NY4892.

\begin{tabular}{lcccc}
\hline Provenience & $\begin{array}{c}\text { Length } \\
(\mathrm{cm})\end{array}$ & $\begin{array}{c}\text { Width } \\
(\mathrm{cm})\end{array}$ & $\begin{array}{c}\text { Thickness } \\
(\mathrm{cm})\end{array}$ & $\begin{array}{c}\text { Weight } \\
(\mathrm{kg})\end{array}$ \\
\hline $935 \mathrm{~N}$ 975E & 26.0 & 11.8 & 2.9 & 2.2 \\
$1239 \mathrm{~N} \mathrm{1295E}$ & 30.0 & 22.0 & 13.0 & 12.0 \\
$1149 \mathrm{~N} \mathrm{1077E}$ & 45.0 & 25.0 & 21.5 & 37.0 \\
\hline
\end{tabular}

waste can probably be considerevi as two separate archaeological records which are superimposed. In addition, it is reasonable to expect that the depositional processes which are operative in each of these systems may have changed through time. Kelly (1988) and Kuhn (1989) have argued that technological and settlement organization affects patterns of tool discard, and organizational changes have undoubtedly occurred in Southern Nevada prehistory. In any case, it seems unlikely that the spatial association of points and artifacts at the site represents a direct occupational relationship.

\section{Effects of Reoccupation}

The current land surface at $26 \mathrm{Ny} 4892$ appears to have been relatively stable throughout human occupation. Temporally sensitive artifacts (i.e., projectile points) at the site range from Great Basin Stemmed to Desert Side-notched which indicate at least intermittent use of this location by prehistoric inhabitants throughout the last 10,000 years. The distribution of cultural material at $26 \mathrm{Ny} 4892$, 26Ny4894, and the 18-(1)3 road sites correlates with suriace distributicins of obsidian nodules and microtopography. Cultural materials are 
TABLE 6-31. FREQUENCIES OF POINT TYPES FROM THE 26 NY4892 SURFACE COLLECTION.

\begin{tabular}{llll}
\hline Group & Series & Count & Proportion \\
\hline Late Holocene & Desert Sidenotched & 1 & \\
Rosegate & 6 & \\
$<2.5$ microns & Bifurcate Base & 1 & $40 \%$ \\
& Subtotal & 8 & \\
Middle Holocene & Elko & 1 & \\
\multirow{2}{*}{$2.5-5.0$ microns } & Gatecliff & 3 & $35 \%$ \\
& Bifurcate Base & 2 & \\
Medium Sidenotched & 1 & \\
Early Holocene & Subtotal & 7 & \\
$>5.0$ microns & Humboldt & 1 & $25 \%$ \\
& Pinto & 1 & \\
& Bifurcate Base & 1 & \\
\hline
\end{tabular}

more frequent on the ridges and knolls of the alluvial fans and sparse on the slopes and swales between these ridges and knolls.

The presence of obsidian nodules on the fan surface appears to have been one of the major attractions in their use. It appears that prehistoric occupants at many different times exploited the obsidian to produce of chippedstone tools. The resu'ts from the test pit exc:3vations and evidence from the examination of roadcuts indicate that obsidian nodules are largely restricted to the surface deposits. As a result, subsurface quarrying of obsidian would have been unproductive, and casual collection of usable pieces from the surface was more likely the aboriginal procurement method.

Reuse of these obsidian nodule scatters over thousands or years has resulted in an overlapping record of prehistoric occupations and activities. As a result, the archaeological record from the Buckboard Mesa Road project represents a complex series of palimpsests. Obsidian exploitation from the site's surface compounds the problem of blurring of distinctive occupations. Procurement and reduction produced many redundant by-products which are ubiquitous throughout the workshop area. Consequently, it is difficult to identify particular activity areas within the general scatter of obsidian artifacts.

The notion that sites like $26 \mathrm{Ny} 4892$ served as significant local sources of obsidian is largely derived from the artifact by-products of procurement and initial reduction which are present at these locations. The obsidian nodule resources which once existed appear to have been severely exhausted. Comparison of the size grade distributions of obsidian debitage and unmodified obsidian nodules collected at $26 \mathrm{Ny} 4892$ is presented in Table 6-32. The obsidian nodule frequencies represent a systematic sample and cannot be compared directly as a ratio to the flake frequencies. In addition, examination of obsidian nodule distributions across the site did not indicate any particular spatial clustering of nodules or differential size sorting. However, Table 6-32 illustrates the differences in obsidian nodule and debitage size distributions. It is clear from these figures that obsidian debitage is general- 
Iy larger than the nodules which are now found at the site. In fact, no obsidian nodules were found in grade 1 (greater than 2-in mesh), only $1.33 \%$ of the obsidian nodule sample is great- er than grade 2 size ( 1 -in mesh), and only $25.15 \%$ is greater than grade 3 size $(1 / 2-i n$ mesh). This evidence implies that obsidian nodule resources depleted.

TABLE 6-32. SIZE GRADE DISTRIBUTIONS OF OBSIDIAN NODULES AND OBSIDIAN DEBITAGE FROM THE 26NY4892 SURFACE COLLECTION.

\begin{tabular}{crrrrr}
\hline Size Grade & \multicolumn{2}{c}{ Obsidian Nodules } & & \multicolumn{2}{c}{ Obsidian Debitage } \\
\cline { 2 - 3 } & $\#$ & $\%$ & & $\#$ & $\%$ \\
\hline 2 & 26 & 01.33 & 156 & 02.69 \\
3 & 466 & 23.82 & 3122 & 53.99 \\
4 & 1273 & 65.08 & 2362 & 40.84 \\
5 & 191 & 09.76 & 143 & 02.47 \\
\hline
\end{tabular}

\section{Reworked Artifacts}

Supporting evidence for the notion that obsidian resources were exhausted at $26 \mathrm{Ny} 4892$ is found in the presence of reworked artifacts. All bifaces, cores, and flake tools (unifaces) which were sorted from the initial analysis were reexamined for evidence of reworking at different time periods. Artifacts which showed unambiguousiy fresher flake removals overlapping patinated or weathered flake surfaces were considered to represent reworking of older artifacts. The observation of overlapping younger flake scars on older flaked surfaces formed the sole criterion for identifying these pieces. Differential weathering on opposing faces of flakes or bifaces was considered an effect of artifact orientation and surface exposure rather than of reworking. Usually, reworking was evident because of differential luster. Older flake scars exhibited a satiny sheen and were overiapped by younger glassy appearing fresh flake(s). The younger flake removals were usually heavy percussion scars that could not be accounted for by unintentional (post-depositional) edge damage.

In a few cases, reworked artifacts were identified on the basis of differential flaking patierns. This category is restricted to a few modi- fied flake tools (scrapers) which exhibited fine marginal retouch that was subsequently obliterated by large and unsystematic percussion scars (Figure 6-25). Three of the conventions of lithic illustration recommended by Addington (1986) are used in the reworked artifact drawings in this report: 1) older weathered scars are noted with dashed lines of percussion, 2) cortex is noted by stippling, and 3) lighting is from the upper left. Since all but specimen 909-10 in Figure 6-25 were recognized on the basis of incongruous flaking patterns, differentially weathered surfaces are not evident. Table 6-33 lists the occurrence of reworked artifacts from $26 \mathrm{Ny} 4892$.

Twenty-five reworked artifacts were identified among the 826 artifacts examined. Although debitage was not examined, the degree of artifact scavenging appears minimal with only $3 \%$ of the sample showing evidence of reworking. Also, this sample probably included the larger and thus more reusable pieces since debitage was excluded. On the other hand, scavenging older artifacts from the surface will not be evident unless there has been sufficient time to alter the older flaked surface. Recycled surface artifacts which have only been exposed for years or decades may 


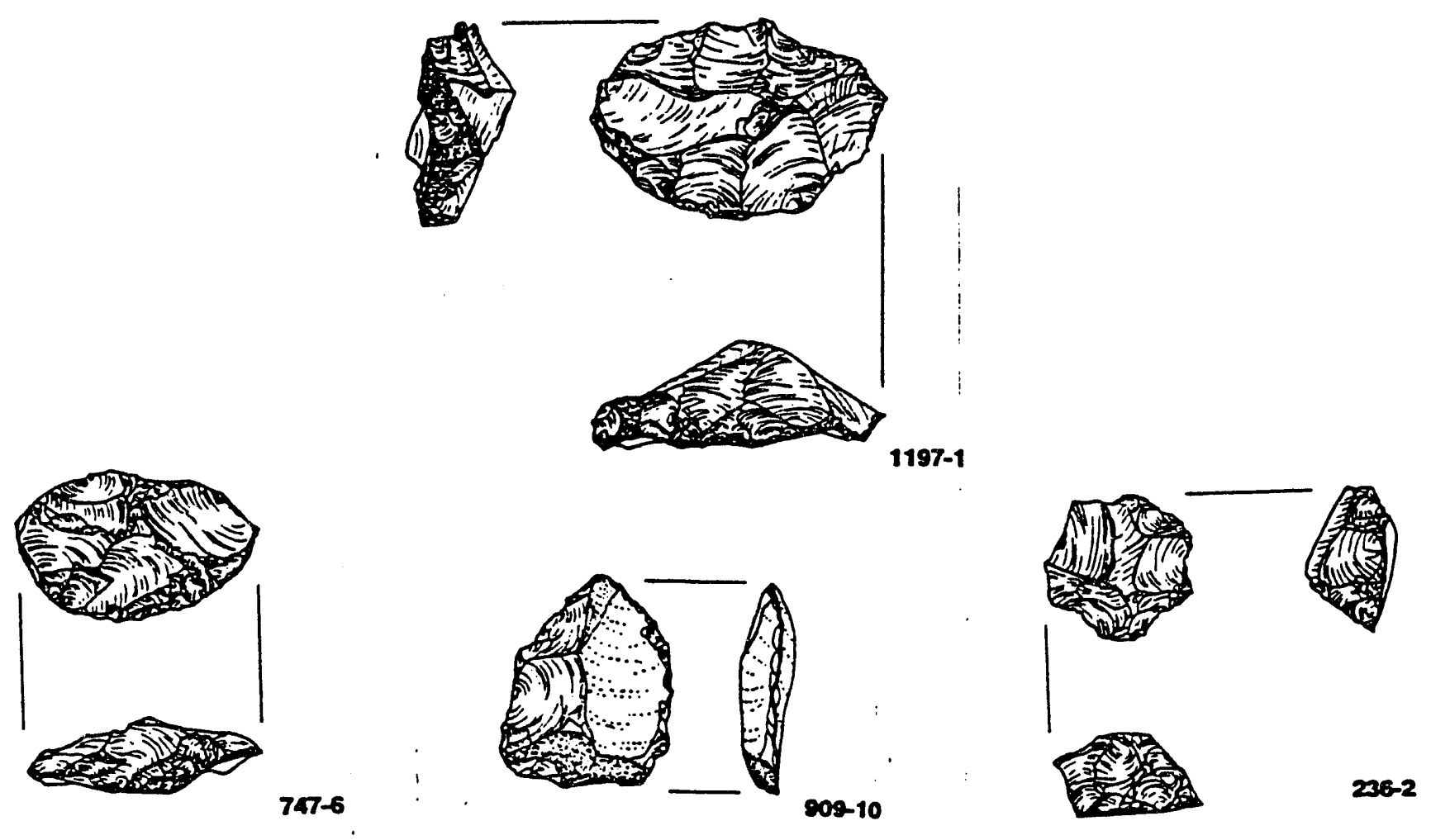

Figure 6-25. Scrapers reworked as cores from $26 \mathrm{Ny} 4892$.

TABLE 6-33. EVIDENCE OF REWORKING OBSIDIAN ARTIFACTS AT 26 NY4892.

\begin{tabular}{lllccc}
\hline $\begin{array}{l}\text { Ref Spc } \\
\text { Number }\end{array}$ & $\begin{array}{l}\text { Original } \\
\text { Artifact }\end{array}$ & $\begin{array}{c}\text { Reworked } \\
\text { Form }\end{array}$ & $\begin{array}{c}\text { Weight } \\
(g)\end{array}$ & $\begin{array}{c}\text { Grid Coordinates } \\
\text { East }\end{array}$ & North \\
\hline $236-2$ & Scraper & Core & 4.4 & 940 & 1060 \\
$264-14$ & Biface & Core & 13.0 & 900 & 1050 \\
$321-5$ & Scraper & Core & 16.0 & 860 & 1060 \\
$556-1$ & Indet. & Point & 3.2 & 1179 & 1014 \\
$705-5$ & Scraper & Core & 3.1 & 1230 & 900 \\
$719-10$ & Core & Core & 5.0 & 1220 & 870 \\
$720-11$ & Scraper & Core & 11.3 & 1220 & 880 \\
$747-6$ & Scraper & Core & 4.6 & 1210 & 960 \\
$785-26$ & Flake & Biface & 12.7 & 1170 & 930 \\
$789-7$ & Flake & Core/Scraper & 7.0 & 1160 & 940 \\
$825-11$ & Flake & Biface & 2.8 & 1140 & 940 \\
$847-9$ & Scraper & Core & 6.3 & 1130 & 1000 \\
$909-10$ & Scraper & Core & 5.4 & 1070 & 950 \\
$918-4$ & Flake & Core & 26.5 & 1080 & 980 \\
$939-7$ & Core & Core & 13.1 & 1040 & 950 \\
$1007-5$ & Flake & Scraper & 3.3 & 900 & 940 \\
$1050-6$ & Core & Core & 23.4 & 830 & 970 \\
$1175-1$ & Flake & Core & 8.7 & 950 & 1190 \\
$1197-1$ & Scraper & Core & 11.8 & 920 & 1190 \\
$1217-1$ & Flake & Core/Scraper & 13.9 & 930 & 1270 \\
$1232-1$ & Core & Core & 41.3 & 930 & 1300 \\
$1420-1$ & Uniface & Scraper & 8.1 & 1070 & 1230 \\
$1484-4$ & Core & Core & 8.8 & 1120 & 1120 \\
$1507-1$ & Flake & Biface & 4.0 & 1130 & 1230 \\
$1766-2$ & Core & Core & 16.4 & Road Sample & Unit E \\
\hline
\end{tabular}


not exhibit differential surface patina. It is more likely that surface weathering of obsidian requires centuries or millennia to develop. As a result, the evidence of recycling that is analytically identifiable probably represents only a small proportion of the artifact recycling that took place. Consequently, these pieces are not necessarily good indicators of the intensity of artifact recycling, but they at least demonstrate that artifact recycling has occurred at this location.

Table 6-34cross-classifies the reworked artifacts according to their original form and their reworked form. For classification as reworked forms, the original artifact form was considered a blank. The predominant recycling strategy appears to be core-type reduction for production of small flakes $(n=17,68 \%)$ (Figures 6-26 and 6-27). Specimen 264-14 in Figure 6-26 also exhibits the characteristic fracture produced by use of the splitting technique during reworking. Three flakes which had bien discarded and weathered were used as biface flake blanks (Figure 6-28). Projectile point specimen 556-1 was manufactured from an unknown weathered artifact type. Four weathered artifacts (16\%) were used to produce scraping tools (Figure 6-29). Scavenging appears to have focused on flakes $(n=8$, $32 \%)$, scrapers $(n=8,32 \%)$, and cores $(n=6$, $24 \%$ ).

The reworked artifacts were also submitted to obsidian hydration analysis. Cuts were made at locations which exhibited differential weathering or flaking patterns, typically on adjacent flake scars. Care was taken to insure that hydration readings directly implicated the adjacent reworked surfaces. Dorsal and ventral differences in exposure and weathering are possible in this assemblage and may affect hydration rates. Therefore, dorsal and ventral miaasurements from a single cut were not averaged. Rim mi:asurements presented by Klimowicz in $\mathrm{Ch}$ pter 9 only represent paired comparisons of adjacent flaked surfaces with differential weathering or flaking patterns.
Table 6-35 shows the appearance and sequence of the paired (original and reworked) flake scars.

The measurements in Table 6-35 indicate that 14 of 16 pairs are tied or have smaller rim measurements on the younger surface. Two specimens (747-6 and 785-26) exhibited significantly larger (0.6 and 0.4 microns) measurements on the younger surface. Since the sequence of flaking is unambiguous, this may indicate measurement error. While hydration readings were taken on the older surface, it is not certain that these readings accurately reflect the age of the flaking. Since older flake scars were often recognized by weathering, it is possible that hydration rims on these surfaces may have been eroded. As such, the older reading is considered to reflect a minimum age. On the other hand, the younger, reworked surface is of particular analytical interest since it is useful to know something about the timing of artifact recycling at $26 \mathrm{Ny} 4892$.

Original and reworked surface hydration measurements are presented in Table 6-36. As expected, the original surfaces exhibit a larger mean (and median) than the reworked surfaces. The variation within measurements for the original surfaces is large $(C V=46 \%)$ suggesting a large time range. Interestingly, the reworked surfaces exhibit a slightly more restricted time range as indicated by smaller variance $(\mathrm{CV}=30 \%)$. The average difference between all paired flaking episodes is about 1 micron. Using the figures provided by Klimowicz (Chapter 9), a rough estimate of about $1000-1500$ years is required for the development of each micron. Thus, the average time differential in the reworked artifacts is about a millennium.

However, the variance is quite high for the paired differences $(C V=141 \%)$ which suggests that the tempo of reworking on artifacts is not well patterned. Thus, this average is probably not very meaningful. Since the paired differences are a function of the original surface rim measurement (which may be 
TABLE 6-34. FREQUENCIES OF ORIGINAL ARTIFACT FORMS BY REWORKED FORMS (26NY4892).

\begin{tabular}{|c|c|c|c|c|c|c|}
\hline \multirow{2}{*}{$\begin{array}{l}\text { Original } \\
\text { Form }\end{array}$} & \multicolumn{6}{|c|}{ Reworked Form } \\
\hline & Scraper & Scraper & Core & Biface & Point & Totals \\
\hline $\begin{array}{l}\text { Flake } \\
C \mid R \\
R \mid C\end{array}$ & $\begin{array}{c}1 \\
12.5 \% \\
50.0 \%\end{array}$ & $\begin{array}{r}2 \\
25.0 \% \\
100.0 \%\end{array}$ & $\begin{array}{l}2 \\
25.0 \% \\
11.8 \%\end{array}$ & $\begin{array}{c}3 \\
37.5 \% \\
100.0 \%\end{array}$ & 0 & $\begin{array}{c}8 \\
32.0 \%\end{array}$ \\
\hline $\begin{array}{c}\text { Scraper } \\
\text { C|R } \\
R \mid C\end{array}$ & 0 & 0 & $\begin{array}{c}8 \\
100.0 \% \\
47.1 \%\end{array}$ & 0 & 0 & $\begin{array}{c}8 \\
32.0 \%\end{array}$ \\
\hline $\begin{array}{l}\text { Core } \\
C \mid R \\
R \mid C\end{array}$ & 0 & 0 & $\begin{array}{c}6 \\
100.0 \% \\
35.3 \%\end{array}$ & 0 & 0 & $\begin{array}{c}6 \\
24.0 \%\end{array}$ \\
\hline $\begin{array}{c}\text { Uniface } \\
C \mid R \\
R \mid C\end{array}$ & $\begin{array}{r}1 \\
100.0 \% \\
50.0 \%\end{array}$ & 0 & 0 & 0 & 0 & $\begin{array}{l}1 \\
4.0 \%\end{array}$ \\
\hline $\begin{array}{r}\text { Biface } \\
C \mid R \\
R \mid C\end{array}$ & 0 & 0 & $\begin{array}{r}1 \\
100.0 \% \\
5.9 \%\end{array}$ & 0 & 0 & $\begin{array}{l}1 \\
4.0 \%\end{array}$ \\
\hline $\begin{array}{l}\text { Indeterminate } \\
\mathbf{C} \mid \mathbf{R} \\
\mathbf{R} \mid \mathbf{C}\end{array}$ & 0 & 0 & 0 & 0 & $\begin{array}{c}1 \\
100.0 \% \\
100.0 \%\end{array}$ & $\begin{array}{l}1 \\
4.0 \%\end{array}$ \\
\hline Totals & $\begin{array}{l}2 \\
8.0 \%\end{array}$ & $\begin{array}{l}2 \\
8.0 \%\end{array}$ & $\begin{array}{l}17 \\
68.0 \%\end{array}$ & $\stackrel{3}{12.0 \%}$ & $\begin{array}{l}1 \\
4.0 \%\end{array}$ & 25 \\
\hline
\end{tabular}

Key: $\quad C \mid R=$ column given row; $R \mid C=$ row given column

eroded) and include potential for measurement error of both surfaces, this high variance is not unexpected. In any case, this patterning seems to suggest that occupations (and reworking) are not discrete punctuated events that are easily related to a few episodes.

To determine if clustering or other spatial patterning was evident at $26 \mathrm{Ny} 4892$, the distribution of all reworked artifacts was plotted in relationship to topography and other artifact distributions. The reworked artifacts were found to be dispersed across the entire site area rather than clustered or arranged in any particular pattern. However, further examination of these distributions indicated that these reworked artifacts were almost always found immediately peripheral to the nore densely clustered artifacts. The reworkid pieces that were identified probably reflect only the small percentage that were not picked up for several centuries and iecame weathered. Recycling of artifacts may have focused on the densest clusters first with older surface artifacts on the peripheries being scavenged when the clusters became exhausted.

It seems likely that much more scavenging of quarry waste was practiced at $26 \mathrm{Ny} 4892$ than is evident from an analyticai standpoint. These data indicate that reworking of discarded quarry debris occurred at numerous times during the past 3000 years. However, recycling may have intensified about 2J00-1000 

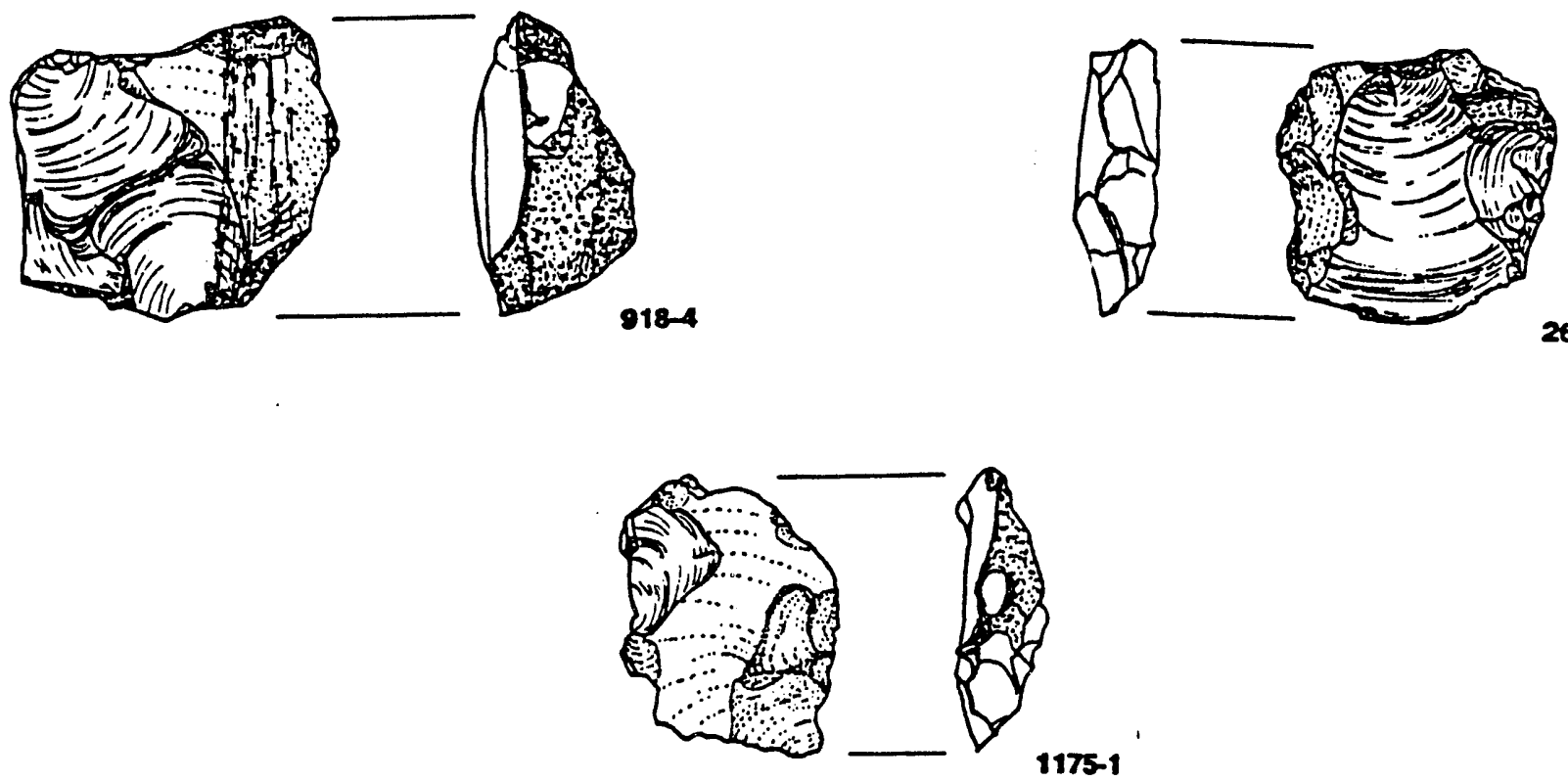

Figure 6-26. Weathered flakes and biface (264-14) reworked as cores from 26Ny4892. Note splitting technique on specimen 264-14.
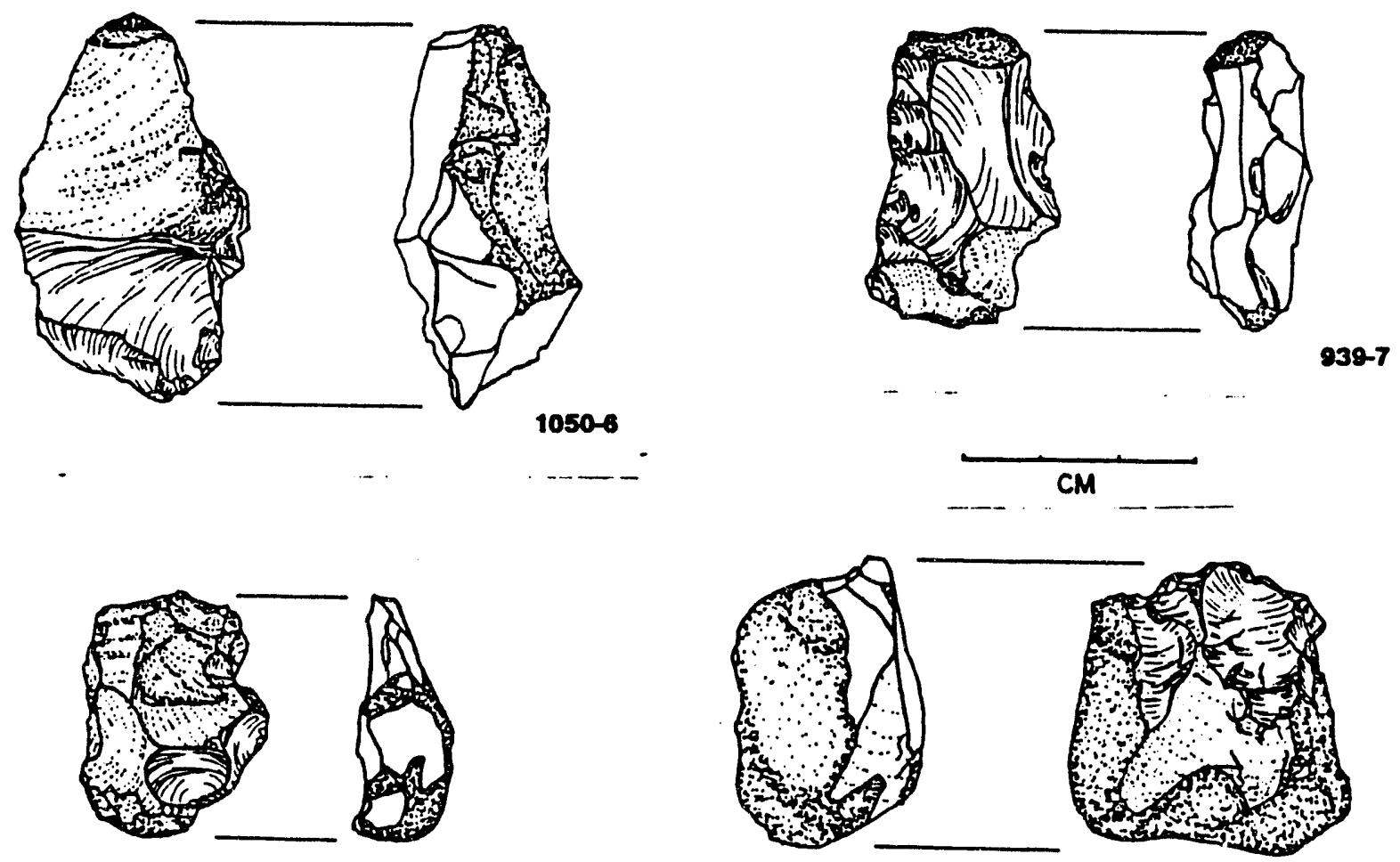

$1484-4$

$1232-1$

Figure 6-27. Cores recycled as cores after weathering from 26 Ny4892. 
15

1010

1

10 
TABLE 6-35. HYDRATION RIMS FOR REWORKED ARTIFACTS FROM 26 Y Y4892. ALL MEASUREMENTS IN MICRONS.

\begin{tabular}{llll}
\hline $\begin{array}{l}\text { Reference } \\
\text { Number }\end{array}$ & $\begin{array}{l}\text { OHL } \\
\text { Number }\end{array}$ & Original & Reworked \\
\hline $236-2$ & $71-72$ & NVH & 1.7 \\
$264-14$ & $67-68$ & 7.7 & 3.8 \\
$747-6$ & $73-74$ & 2.4 & 3.0 \\
$785-26$ & $69-70$ & 1.9 & 2.3 \\
$789-7$ & $95-96$ & 4.5 & 1.7 \\
$825-11$ & $97-98$ & 2.1 & 1.3 \\
& & 2.1 & 1.6 \\
$909-10$ & $99-100$ & 2.7 & 2.2 \\
$918-4$ & $77-78$ & 2.4 & 2.4 \\
$939-7$ & $79-80$ & 2.3 & 2.3 \\
$1007-5$ & $101-102$ & $N V H$ & NVH \\
$1050-6$ & $81-82$ & 2.4 & 1.8 \\
$1175-1$ & $83-84$ & 5.3 & 2.7 \\
$1197-1$ & $75-76$ & 3.1 & 3.0 \\
$1217-1$ & $103-104$ & 3.1 & 2.7 \\
$1222-1$ & $85-86$ & 3.1 & 2.8 \\
$1484-1$ & $87-88$ & 4.0 & 3.2 \\
$1507-1$ & $93-94$ & 4.5 & 1.3 \\
\hline
\end{tabular}

Key: $\quad \mathrm{NVH}=$ No Visible Hydration Rim, OHL = Obsidian Hydration Laboratory

TABLE 6-36. DISTRIBUTIONAL STATISTICS OF HYDRATION READINGS FROM REWORKED ARTIFACTS AT 26 NY4892.

\begin{tabular}{lccccccc}
\hline & \multicolumn{7}{c}{ Mean Hydration Rim (microns) } \\
\cline { 2 - 8 } $\begin{array}{l}\text { Artifact } \\
\text { Surface }\end{array}$ & $\mathrm{n}$ & Mean & $\begin{array}{l}\text { Std } \\
\text { Dev }\end{array}$ & CV & Median & $\begin{array}{c}\text { 75th } \\
\text { \%tile }\end{array}$ & $\begin{array}{c}\text { 25th } \\
\text { \%tile }\end{array}$ \\
\hline Original & 16 & 3.35 & 1.54 & 0.46 & 2.90 & 4.25 & 2.35 \\
Reworked & 17 & 2.34 & 0.71 & 0.30 & 2.30 & 2.80 & 1.70 \\
Paired & 16 & 0.97 & 1.37 & 1.41 & 0.50 & 1.70 & 0.05 \\
Differences & 16 & & &
\end{tabular}

Key: $\quad n=$ number, Std Dev = standard deviation; CV = coefficient of variation (std. dev. $\times 100 /$ mean) 
years ago as evidenced by the clustering of surface dates for reworked flakes during this interval. Based on the intensity of obsidian exploitation suggested by this behavior, the economic value of this obsidian nodule source increased significantly during the late Holocene. The shift to smaller tool forms at this time (especially Rosegate and DSN points) may have played an important role in making the obsidian nodules and quarry by-products a more viable toolstone source.

\section{Summary and Discussion}

Consideration of the geologic and physiographic setting at Buckboard Mesa provides several important conclusions which relate to the surface dynamics and local obsidian exploitation. Stratigraphic evidence suggests that the surface debris represents at least 10,000 years of intermittent human occupation. The exploitation of local obsidian nodules seems to have been ain important use of this place for at least some prehistoric groups. Through time it appears that the obsidian nodule resources may have become depleted and that recycling of previously discarded debris occurred. This active recycling of surface debris has probably compromised the spatial patterning of artifacts. The intensive use of this place over a long period of time is compressed into an essentially vertical archaeological re- cord although some shallow subsurface size sorting is evident. The combination of a vcrtical palimpsest depositional record and intensive prehistoric surface collection of obsidian nodules and workshop debris has probably complicated any patterns of spatial differentiation of activities which may have been evident at these locations. As a result, analytical efforts are more profitably directed toward technological evidence regarding the use of this place rather that spatial patterns of site structure.

Understanding the mode and ternpo of site utilization is essential to archaeological interpretation at 26Ny4892. Unfortunately, complex palimpsest archaeological records, like 26Ny4892, pose a considerable challenge to interpretation. Nonetheless, there are numerous clues which may relate to the use of this place by prehistoric peoples. These clues for the most part are based on the type of archaeological assemblage recovered and its spatial patterning.

\section{Distributional Comparisons}

The density distribution of wasteflakes from the surface of $26 \mathrm{Ny} 4892$ is presented in Table 6-37. The majority $(n=1265,60.7 \%)$ of 10-by-10 m surface collection units are composed of 1-10 flakes. Nearly one-third $(n=666$, $31.9 \%)$ of the collection units contained no

TABLE 6-37. DEBITAGE DENSITY FREQUENCIES PER 10-BY-10 M GRID UNIT FROM THE MAIN SURFACE COLLECTION AT $26 N Y 4892$.

\begin{tabular}{ccc}
$\begin{array}{c}\text { Number of } \\
\text { Fiakes per } \\
\text { 10-by-10 } \mathrm{m} \\
\text { Grid Units }\end{array}$ & $\begin{array}{c}\text { Number of } \\
\text { Grid Units }\end{array}$ & $\begin{array}{c}\text { Percentage of } \\
\text { Grid Units }\end{array}$ \\
\hline None & 666 & 31.9 \\
$1-10$ & 1265 & 60.7 \\
$11-20$ & 108 & 5.2 \\
$21-30$ & 26 & 1.2 \\
$31-40$ & 13 & 0.6 \\
$41-50$ & 2 & 0.1 \\
$51-99$ & 3 & 0.1 \\
$00-200$ & 2 & 0.1 \\
\hline
\end{tabular}


flakes at all. The meaning of zero cell grid units remains unclear since survey boundaries are based on artifact clustering and arbitran; decisions made in the field about that clustering. In addition, the collection boundaries are contingent upon the spatial extent of the road project. In any case, it is significant that the $26 \mathrm{Ny} 4892$ surface collections yielded less than 10 artifacts in $92.6 \%(n=1931)$ of the grid collection units. There are few high density clusters of material. High densities of debitage are found on the low ridges and generally follow the elevational contours of the site. A few small isolated areas on these low ridges contain the highest frequencies of debitage. These extreme "hot spots" also exhibit unusually high artifact diversity and may represent areas of short-term residence within the quarry or more intensive lithic workshop locations.

Comparison of the $26 \mathrm{Ny} 4892$ data with debitage densities for Pahute and Rainier mesas (Pippin 1986:151-158) provides a rough frame of reference. The $26 \mathrm{Ny} 4892$ total surface collection area is 2085 grid units; 7503 pieces of debitage were found in this area for an average of 0.035986 flakes per square meter. This figure is only an approximation as corrections for partial collection units were not made. The debitage densities for Pahute and Rainier mesas (Pippin 1986:151-158) range from 0.000021 (26Ny3629) to 22.750000
(26Ny4193). Of course, the same cavears about zero cells and projert boundaries apply here as well. In fact, Table 6-38 shows that more than half $(n=124,55.1 \%)$ of the 10-by-10 $\mathrm{m}$ grid units from these surface collections average less than a single flake. Only 45.9\% $(n=101)$ exhibit more than one flake per 10-by-10 $\mathrm{m}$ grid unit. Surface debitage density at 26 Ny 4892 is 3.5986 flakes per 10-by-10 $\mathrm{m}$ grid unit which is close to the modal group for any of the various site classes from Pahute Mesa.

Although Table 6-38 indicates a trend for higher debitage densities among bifacial reduction and special task sites over temporary campsites, this pattering is slight, and considerable overlap exists. In addition, the classification of site classes is probably partially dependent upon debitage density which determined this pattern. Placement of the 26 Ny4892 quarry data within these distributions suggests that debitage density may not be useful in distinguishing functional site classes. Since 26 Ny 4892 is a lithic quarry, a much higher density of debris might be expected, but 3.5986 flakes per 10-by-10 m unit is not incongruous with densities from many nonquarry localities on Pahute and Rainier mesas.

Comparison of artifact densities from $26 \mathrm{Ny} 4892$ to another obsidian nodule quarry

TABLE 6-38. DEBITAGE DENSITY FREQUENCIES AND COLUMN PERCENTAGES FROM VARIOUS SITE CLASSES ON PAHUTE AND RAINIER MESAS.

\begin{tabular}{|c|c|c|c|c|c|c|c|c|}
\hline \multirow{3}{*}{$\begin{array}{l}\text { Debitage } \\
\text { Density per } \\
\text { 10-by-10 m } \\
\text { Grid Unit }\end{array}$} & \multicolumn{8}{|c|}{ Site Class } \\
\hline & \multicolumn{2}{|c|}{$\begin{array}{l}\text { Bifacial } \\
\text { Reduction }\end{array}$} & \multicolumn{2}{|c|}{$\begin{array}{c}\text { Special } \\
\text { Task }\end{array}$} & \multicolumn{2}{|c|}{$\begin{array}{l}\text { Temporary } \\
\text { Campsites }\end{array}$} & \multicolumn{2}{|c|}{$\begin{array}{l}\text { Milling } \\
\text { Stations }\end{array}$} \\
\hline & $\#$ & $\%$ & $\#$ & $\%$ & $\#$ & $\%$ & $\#$ & $\%$ \\
\hline $0.0001-0.0099$ & 4 & 4.3 & 2 & 3.7 & 4 & 5.1 & 0 & \\
\hline $0.001-0.099$ & 8 & 8.6 & 5 & 9.3 & 21 & 26.6 & 0 & \\
\hline $0.01-0.99$ & 32 & 34.4 & 23 & 42.6 & 22 & 27.8 & 3 & 42.9 \\
\hline $1.0-9.9$ & 23 & 25.0 & 12 & 22.2 & 20 & 25.3 & 4 & 57.1 \\
\hline $10-99$ & 19 & 20.7 & 11 & 20.4 & 8 & 10.1 & 0 & \\
\hline$\geq 100$ & 6 & 6.5 & 1 & 1.9 & 4 & 5.1 & 0 & \\
\hline
\end{tabular}


may provide a more relevant frame of reference. Data from the distribution maps of the $10 \%$ sample at the Butte Wash Site (26Ny3121) provide a local comparison (Reno and Pippin 1985:119). Although the grid units at the Butte Wash Site are four times larger in size (20-by-20 $\mathrm{m}$ grid units) than the 26 Ny4892 grid units, density is much lower. Within the $10 \%$ surface sample at $26 \mathrm{Ny} 3121$. $14.8 \%$ of the units had no artifacts, $75.1 \%$ had 1-10 artifacts, and $10.1 \%$ had $11-20$ artifacts (extrapolated from Reno and Pippin 1985:119). Both $26 \mathrm{Ny} 4892$ and $26 \mathrm{Ny} 3121$ are quarries of small obsidian nodules but these siies do not resemble each other on the basis of debitage density. This difference is at least partially a function of the surface density and distribution of the obsidian nodules. Obsidian resources at the Butte Wash Site are much more dispersed than at 26Ny4892. These comparisons indicate that the density of debitage at any locality is a function of numerous factors: the density, distribution, and type of toolstone available; tool manufacturing needs; situational problems related to gear transport; technological organization; mobility systems; and surficial geomorphology.

\section{Assemblage Comparisons}

The composition of the artifact assemblage provides several keys to understanding occupational history at $26 \mathrm{Ny} 4892$. The artifact assemblage is overwhelmingly represented by the scattered debris from obsidian reduction which defines the site. The absence of ceramic sherds and the paucity of grinding stones and burned rocks are significant. Among late Holocene groups, these artifact classes are expected to reflect domestic activities and may correspond to residential camps. The lack of these artifacts at $26 \mathrm{Ny} 4892 \mathrm{implies}$ that domestic and residential locations were located elsewhere. While the quarry has a close spatial relationship to the Buckboard Mesa rockshelters, these sites are not necessarily related.

However, the rockshelter assemblages (Chapter 4 by Henton) provide an interesting contrast with the $26 \mathrm{Ny} 4892$ assemblage. They contain groundstone implements, ceramic sherds, and biface thinning (tool finishing and maintenance) debris. To a large degree, the rockshelters present the complementary domestic assemblage that is missing at 26Ny4892. While prehistoric settlement patterns at the NTS are certainly more complex than this dichotomy suggests, the distinction between domestic and nondomestic locations is clear within this group of sites. This dichotomous pattern based on domestic activities is expected to result under conditions of small social groups with family-based economies. These data suggest that small group composition parameters may be the fundamental conditioners of settlement and technological organization in Southern Nevada, especially during the late Holocene.

Table 6-39 presents a general summary of the assemblage which cross-classifies artifact classes by material types. The data in this table contrasts to those for the Butte Wash Site (26Ny3121) assemblage (Reno and Pippin 1985:122-123. The obsidian artifacts from 26 Ny3121 are comprised of about $96 \%$ flakes, $3 \%$ bifaces, $<1 \%$ cores, and $<1 \%$ flake tools. The obsidian assemblage from $26 \mathrm{Ny} 4892 \mathrm{ex}$ hibits relatively more debitage, fewer cores, and more bifaces. The core-to-biface ratio at 26 Ny3121 is about $1: 3.5$ versus $2: 1$ at 26Ny4892. These inverse ratios present an analytical problem. The differences may reflect less core reduction and more biface reduction at $26 \mathrm{Ny} 3121$. The more sparse distribution of obsidian nodules at 26Ny3121 may have compromised its utility as a toolstone source, and the $26 \mathrm{Ny} 3121$ assemblage may reflect less quarrying activity. As a result, much of the debris at $26 \mathrm{Ny} 3121$ is the resuit of maintaining transported toolstone rather than procureing and initially manufacturing tools.

The obsidian debitage from $26 \mathrm{Ny} 3121$ provides some support for this notion. Its composition is about $20 \%$ decortication, $20 \%$ core reduction ("primary"), 20\% biface thinning, 
TABLE 6-39. CROSS TABULATION OF ARTIFACT CLASSES BY MATERIAL TYPES FROMTHE 26NY4892 SURFACE ASSEMBLAGE.

\begin{tabular}{|c|c|c|c|c|c|}
\hline \multirow[b]{2}{*}{$\begin{array}{l}\text { Artifact } \\
\text { Class }\end{array}$} & \multicolumn{5}{|c|}{ Material Type } \\
\hline & Obsidian & $\begin{array}{l}\text { Sillicified } \\
\text { Tuff }\end{array}$ & $\begin{array}{l}\text { Vein } \\
\text { Opal }\end{array}$ & $\begin{array}{c}\text { Chert/ } \\
\text { Chalcedony }\end{array}$ & Totals \\
\hline $\begin{array}{r}\text { Debitage } \\
\text { C|R } \\
\text { R|C }\end{array}$ & $\begin{array}{l}6862 \\
91.5 \% \\
92.5 \%\end{array}$ & $\begin{array}{r}616 \\
8.2 \% \\
98.7 \%\end{array}$ & $\begin{array}{l}18 \\
0.2 \% \\
47.4 \%\end{array}$ & $\begin{array}{l}3 \\
<0.1 \% \\
30.0 \%\end{array}$ & $\begin{array}{l}7499 \\
92.7 \%\end{array}$ \\
\hline $\begin{array}{r}\text { Flake Tools } \\
\text { C|R } \\
\text { R|C }\end{array}$ & $\begin{array}{l}45 \\
95.7 \% \\
0.6 \%\end{array}$ & 0 & $\begin{array}{l}2 \\
4.3 \% \\
5.3 \%\end{array}$ & 0 & $\begin{array}{l}47 \\
0.6 \%\end{array}$ \\
\hline $\begin{array}{l}\text { Cores } \\
\text { C } \mid R \\
\text { R|C }\end{array}$ & $\begin{array}{l}359 \\
95.7 \% \\
4.8 \%\end{array}$ & $\begin{array}{l}7 \\
1.9 \% \\
1.1 \%\end{array}$ & $\begin{array}{l}9 \\
2.4 \% \\
23.7 \%\end{array}$ & 0 & $\begin{array}{l}375 \\
4.6 \%\end{array}$ \\
\hline $\begin{array}{r}\text { Early Stage Bifaces } \\
C \mid R \\
R \mid C\end{array}$ & $\begin{array}{l}63 \\
98.4 \% \\
0.8 \%\end{array}$ & $\begin{array}{l}1 \\
0.6 \% \\
0.2 \%\end{array}$ & 0 & 0 & $\begin{array}{l}64 \\
0.8 \%\end{array}$ \\
\hline $\begin{array}{r}\text { Bifacially Edged Flakes } \\
C \mid R \\
R \mid C\end{array}$ & $\begin{array}{l}43 \\
93.5 \% \\
0.6 \%\end{array}$ & 0 & 0 & $\begin{array}{l}3 \\
6.5 \% \\
30.0 \%\end{array}$ & $\begin{array}{l}46 \\
0.6 \%\end{array}$ \\
\hline $\begin{array}{r}\text { Late Stage Bifaces } \\
C \mid R \\
\mathbf{R} \mid \mathbf{C}\end{array}$ & $\begin{array}{l}25 \\
71.4 \% \\
0.3 \%\end{array}$ & 0 & $\begin{array}{l}7 \\
20.0 \% \\
18.4 \%\end{array}$ & $\begin{array}{l}3 \\
8.6 \% \\
30.0 \%\end{array}$ & $\begin{array}{l}35 \\
0.4 \%\end{array}$ \\
\hline $\begin{array}{r}\text { Projectile Points } \\
\text { C|R } \\
R \mid C\end{array}$ & $\begin{array}{l}19 \\
86.4 \% \\
0.3 \%\end{array}$ & 0 & $\begin{array}{l}2 \\
9.1 \% \\
5.3 \%\end{array}$ & $\begin{array}{c}1 \\
4.5 \% \\
10.0 \%\end{array}$ & 22 \\
\hline Totals & $\begin{array}{l}7416 \\
91.7 \%\end{array}$ & $\begin{array}{l}624 \\
7.7 \%\end{array}$ & $\begin{array}{l}38 \\
0.5 \%\end{array}$ & $\begin{array}{l}10 \\
0.1 \%\end{array}$ & 8088 \\
\hline
\end{tabular}

Key: $\quad C \mid R=$ Column given row; $R \mid C=$ row given column.

$45 \%$ indeterminate, and $5 \%$ pressure and shatter. These figures are based on rough estimates from histograms and line graphs presented by Reno and Pippin (1985:122-123). Compared to $26 \mathrm{Ny} 4892$, decortication and core reduction flakes are underrepresented while BTFs and indeterminates are overrepresented. Overall there seems to be less emphasis on quarrying at $26 \mathrm{Ny} 3121$ which is probably related to the relative scarcity of obsidian nodules compared to $26 \mathrm{Ny} 4892$.

The occurrence of non obsidian at both sites is most common among poirits, bifaces, core reduction flakes, BTFs, and indeterminate fiakes. This pattern suggests that non obsidian materials are common in the toolkit which is transported to these lowland locations. It seems likely that the sources of these non obsidian cryptocrystallines are in upland locations. Projectile points indicate occupations throughout the Holocene at $26 \mathrm{Ny} 3121$. but an absence of the Rosegate and GBS Series serves as a notable difference with 26Ny4892. While casual quarrying may have occurred at $26 \mathrm{Ny} 3121$, it does not appear to be similar to the more intensive lithic procurement activities occurring at $26 \mathrm{Ny} 4892$.

Table 6-40 summarizes the biface reduction trajectory at $26 \mathrm{Ny} 4892$. The thinning index (TI) value for the single silicified tuff biface is quite large compared to the obsidian which may indicate this is simply a large bifacial core. 
Table 6-40. Thinning Indices for Bifaces from 26Ny4892.

\begin{tabular}{|c|c|c|c|c|c|c|c|}
\hline \multirow[b]{2}{*}{$\begin{array}{l}\text { Biface } \\
\text { Blank Type }\end{array}$} & \multicolumn{6}{|c|}{ Thinning Index (grams/square $\mathrm{cm}$ ) } & \multirow[b]{2}{*}{$\begin{array}{l}\text { 25th } \\
\text { \%tile }\end{array}$} \\
\hline & n & Mean & $\begin{array}{l}\text { Std } \\
\text { Dev }\end{array}$ & CV & Median & $\begin{array}{l}\text { 75th } \\
\% \text { tile }\end{array}$ & \\
\hline \multicolumn{8}{|l|}{ Silicified } \\
\hline $\begin{array}{l}\text { Turf Biface } \\
\text { * Nodule Blank } \\
\text { * Indeterminate }\end{array}$ & $\begin{array}{l}1 \\
9\end{array}$ & $\begin{array}{l}2.43 \\
1.36\end{array}$ & $\overline{0.28}$ & $\overline{0.21}$ & $\overline{1.40}$ & $\overline{1.52}$ & $\overline{1.31}$ \\
\hline $\begin{array}{l}\text { Blank } \\
\text { @ No Breaks }\end{array}$ & $\begin{array}{l}38 \\
40\end{array}$ & $\begin{array}{l}1.33 \\
1.26\end{array}$ & $\begin{array}{l}0.38 \\
0.31\end{array}$ & $\begin{array}{l}0.28 \\
0.24\end{array}$ & $\begin{array}{l}1.32 \\
1.31\end{array}$ & $\begin{array}{l}1.43 \\
1.50\end{array}$ & $\begin{array}{l}1.10 \\
1.05\end{array}$ \\
\hline $\begin{array}{l}\text { ¿Split Nodule } \\
\text { Blank } \\
\text { "Soft Hammer }\end{array}$ & 16 & 1.24 & 0.30 & 0.24 & 1.22 & 1.46 & 1.01 \\
\hline $\begin{array}{l}\text { Percussion } \\
\text { Absent }\end{array}$ & 115 & 1.15 & 0.36 & 0.32 & 1.12 & 1.37 & 0.89 \\
\hline @ One Break & 71 & 1.09 & 0.42 & 0.38 & 1.07 & 1.33 & 0.77 \\
\hline $\begin{array}{l}\text { Bifaces } \\
\text { Edged Flake }\end{array}$ & 151 & 1.06 & 0.36 & 0.34 & 1.03 & 1.31 & 0.76 \\
\hline $\begin{array}{l}\text { Blank } \\
\text { Cherty }\end{array}$ & 44 & 1.01 & 0.26 & 0.26 & 1.01 & 1.22 & 0.77 \\
\hline $\begin{array}{l}\text { Chalcedony Bifaces } \\
\text { @ Two Breaks }\end{array}$ & $\begin{array}{r}7 \\
36\end{array}$ & $\begin{array}{l}0.94 \\
0.91\end{array}$ & $\begin{array}{l}0.29 \\
0.25\end{array}$ & $\begin{array}{l}0.31 \\
0.27\end{array}$ & $\begin{array}{l}0.89 \\
0.89\end{array}$ & $\begin{array}{l}1.21 \\
1.05\end{array}$ & $\begin{array}{l}0.72 \\
0.69\end{array}$ \\
\hline $\begin{array}{l}\text { Soft Hammer } \\
\text { Percussion }\end{array}$ & & & & & & & \\
\hline $\begin{array}{l}\text { Present } \\
\text { - Late Stage }\end{array}$ & 36 & 0.85 & 0.22 & 0.27 & 0.74 & 0.94 & 0.69 \\
\hline $\begin{array}{l}\text { Bifaces } \\
\text { Vein Opal }\end{array}$ & 25 & 0.82 & 0.20 & 0.24 & 0.81 & 0.94 & 0.69 \\
\hline Bifaces & 9 & 0.79 & 0.16 & 0.21 & 0.76 & 0.94 & 0.65 \\
\hline $\begin{array}{l}\text { @ Three Breaks } \\
\text { @ Four Breaks }\end{array}$ & $\begin{array}{r}19 \\
2\end{array}$ & $\begin{array}{l}0.78 \\
0.76\end{array}$ & 0.18 & 0.23 & 0.73 & 0.97 & 0.61 \\
\hline t Points & 9 & 0.71 & 0.18 & 0.25 & 0.69 & 0.72 & 0.60 \\
\hline
\end{tabular}

Key: $\quad$ Obsidian only; @ all material types combined.

$n=$ number; Std Dev = standard deviation; $C V=$ coefficient of variation (std. dev. $\times 100 /$ mean)

Obsidian quarrying debris at $26 \mathrm{Ny} 4892$ is predominantly the result of hard hammer percussion. Biface production failures from soft hammer thinning and finishing are infrequent. Edged flake blanks enter the reduction trajectory about midway (mean $\mathrm{TI}=1.10$ ) between early stage bifaces (mean TI ranges from 1.24 to 1.36) and finished bifaces (mean $\mathrm{TI}$ about 0.82 to 0.71 ). This value indicates that about half of the biface reduction effort may be short cut through the use of flake blanks. Edged flake blank bifaces seem to reflect considerably more efficient use of manufacturing time and less wasteful use of toolstone. As a result, biface production at $26 \mathrm{Ny} 4892$ probably cen- tered on edged flake blanks which were then transported for further thinning and shaping at another (residential?) location. The use of nodules and split nodules for biface production was probably secondary to flake blank manufacture. If nodules were unsuitable for flake blank production or flake blank cores became exhausted, there may have been some attempts to stream them into the biface trajectory. Breakage of the obsidian bifaces usually caused termination of the manufacturing process. Multiple breakage is more common among late stage bifaces and probably represents pieces which were manufactured elsewhere but discarded at $26 \mathrm{Ny} 4892$. 


\section{SITE 26Ny4894: AN OBSIDIAN NODULE QUARRY}

l.aurie A. Walsh

Site 26 Ny 4894 is a diffuse lithic reduction station situated on a small north-south trending ridge above Buckboard Mesa Wash (Figure 4-1; Chapter 4 by Henton). Alluvial deposits at the site area are capped by well developed desert pavement; small obsidian nodules and pebbles are a component of the pavement. The site is located north of the junction of the Buckboard Mesa and 18-03 roads; these road beds and the new Buckboard Mesa Road bed to the north have truncated the original site boundaries (Henton 1986b). The remaining portion of the site is roughly triangular and measures $60 \mathrm{~m}$ north-south by $120 \mathrm{~m}$ eastwest.

\section{Surface Collection}

Fifty-three 10-by-10 m collection units were systematically collected. Seventeen (32\%) of these contained no cultural material. A total of 165 lithic artifacts were collected from the surface of 26 Ny4894: 153 (92.7\%) pieces of debitage, $11(6.6 \%)$ cores, and $1(0.6 \%)$ biface. With the exception of $3(1.8 \%)$ flakes, all of the artifacts are obsidian. All of the toolstone materials occur in the immediate vicinity of the site.

\section{Debitage}

Of the 153 flakes recovered, three (1.8\%) pieces of non obsidian debitage were identified. Two are indeterminate vein opal flake fragments and one is a grade $3(1-1 / 2$ inch) silicified tuff core reduction flake. The obsidian debitage assemblage from $26 \mathrm{Ny} 4894$ is summarized in Table 7-1. The spatial distribution of these artifacts is homogeneous without any discernible concentrations. The average frequency of flakes per unit is 4.6; the range is from 1 to 12 flakes per $10-$ by- $10 \mathrm{~m}$ unit.

\section{Cores}

Eleven obsidian cores were recovered from the site. Four ( $36.3 \%)$ are classified as incipient and 7 (63.4\%) as multidirectional. Nine $(81.8 \%)$ of these artifacts exhibit 1-50\% cortical coverage, and 2 (18.2\%) exhibit 51-99\% coverage; $10(91 \%)$ cores have a single cortex relict and 1 specimen has $2(9 \%)$ relicts. Among identifiable nucleus types, 2 (18.2\%) specimens have been manufactured on flakes, 2 (18.2\%) on split cobbles, and 2 (18.2\%) on nodules. The average core dimensions are 36-by-30-by-13 $\mathrm{mm}$. Weight

TABLE 7-1. SUMMARY OF OBSIDIAN FLAKE TYPE AND SIZE AT 26 NY4894.

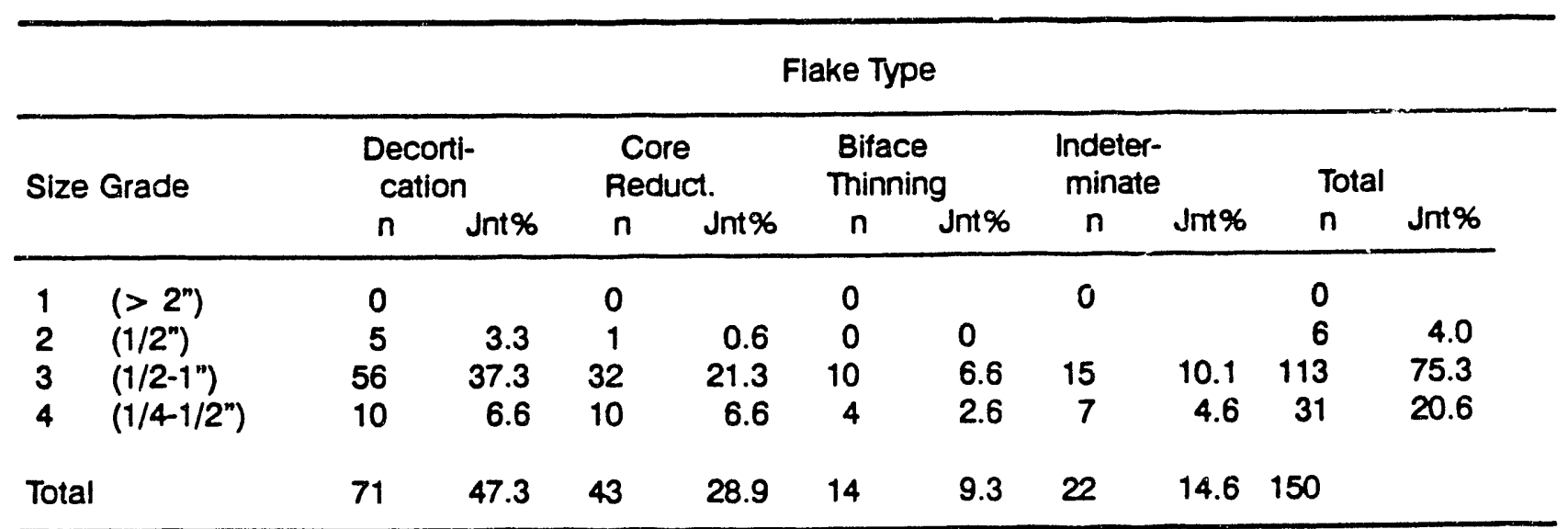

Key: Jnt $\%=$ overall percentage 
ranges from 4.2 to $35.6 \mathrm{~g}$; the average weight is $16.7 \mathrm{~g}$.

\section{Bifaces}

A single, obsidian, late stage biface was recovered from $26 \mathrm{Ny} 4894$. This proximal fragment was manufactured on a flake measuring 15-by-23-by-3 mm and weighing $1.4 \mathrm{~g}$.

\section{Summary and Discussion}

The presence of 14 (9.3\%) pieces of obsidian debitage classified as biface thinning flakes and a single biface fragment demonstrates that some bifacial reduction occurred at the site. The lack of pressure flakes indicates that little, if any, finishing work and/or tool rejuvenation took place.

Perhaps the most distinctive aspect of this assemblage is the clustering of flakes by type and size. One hundred fourteen pieces (76.2\%) of debitage are classified as decortication and core reduction flakes. One hundred thirteen $(75.3 \%)$ are $1 / 2-1$ inch in size. Over half $(n=88,59 \%)$ of the pieces of debitage are comprised of $1 / 2-1$ inches decortication and core reduction flakes. The preponderance of flakes of this size and the patterns evident on the cores suggest that the reduction system at this site involved the produc- tion of relatively large flakes from at least two types of cores. The cores at this locality are generally lozenge shaped with flakes removed from opposite faces. This reduction technique maintains the maximum dimensions of the raw material allowing for the production of larger flakes. The dearth of flakes greater than 2 inches may be related to the size of the raw material and/or the selection of such flakes as blanks. The lack of flakes less than $1 / 4$ inch may be due to the successful removal of larger flakes and/or postdepositional agents that removed those flakes from the surface.

In summary, 26Ny4894 appears to represent a locality that focused on the reduction of locally available obsidian nodules for the production of flakes. Additionally, obsidian nodules, cores, and flakes could have been transported elsewhere for reduction. Some flakes may have entered a bifacial reduction sequence at the site, or intermediate stage bifaces may have been carried in. However, the relative importance of bifacial reduction appears to be less significant than core reduction. There is no evidence that pressure work took place. The three non obsidian flakes indicate that limited reduction of non obsidian pieces may have occurred at this location. 


\title{
8. THE 18-03 ROAD SITES: OBSIDIAN QUARRY SCATTERS
}

\author{
Laurie A. Walsh
}

A series of sites (numbered consecutively 26Ny5431-5442) north of the 18-03 Road were sampled for surface artifacts (Figure 4-1; Chapter 4 by Henton). These sites are situated on north-south trending ridges separated by ephemeral drainages that dissect alluvial deposits (Reno 1987). Well-developed desert pavement has formed on ridge top deposits, and gravel-sized obsidian nodules are a component of the pavement. Northern boundaries of the sites are not defined, and southern boundaries are determined by the 18-03 Road cut. A 30 -by- 30 m collection grid was systematically examined and collected at each site, and an additional four 10-by-10 m units were collected at $26 \mathrm{Ny} 5431$. The 336 lithic artifacts collected from these sites are summarized in Tables 8-1 and 8-2.

\section{Projectile Points}

Two projectile points were recovered from the 18-03 Road survey. Great Basin Stemmed projectile points were recovered from both
26Ny5431 and 26Ny5442. Although these projectile points may be 9000 years old (Henton and Pippin 1988:18), the associated artifacts are assumed to be younger. However, casual use of these obsidian nodules by earlier peoples cannot be discounted. These points are described below and metric information is provided in Table 8-3.

\section{Iype: Great Basin Stemmed Series}

Number of Specimens: 2

Reference Numbers: 26Ny5431-1-1; 26Ny5442-7-1

Figure: 6-22

Material: Obsidian

Hydration Rims: mean 8.94 microns, range 11.38-6.5 microns

Comments: Specimen 26Ny5431-1-1 has been reworked and battered on the blade. The base exhibits steep well-ground bevels on opposite faces of the stem margins and a retouched transverse hinge fracture that trun-

TABLE 8-1. SUMMARY OF LITHIC ARTIFACTS FROM THE 18-03 ROAD SITES.

\begin{tabular}{|c|c|c|c|c|c|c|c|c|c|c|c|}
\hline \multirow[b]{2}{*}{ Site } & \multicolumn{2}{|c|}{$\begin{array}{c}\text { Bifacial } \\
\text { Coles }\end{array}$} & \multicolumn{2}{|c|}{$\begin{array}{l}\text { non obsidian } \\
\text { Artifacts }\end{array}$} & \multicolumn{2}{|c|}{$\begin{array}{l}\text { Obsidian } \\
\text { Debitage }\end{array}$} & \multicolumn{2}{|c|}{$\begin{array}{c}\text { Flake } \\
\text { Debitage }\end{array}$} & \multicolumn{2}{|c|}{ Tools } & \multirow{2}{*}{ Total } \\
\hline & $n$ & $\%$ & $n$ & $\%$ & $n$ & $\%$ & $n$ & $\%$ & $n$ & $\%$ & \\
\hline 26Ny5431 & 1 & 6.2 & 1 & 6.2 & 5 & 31.2 & 9 & 56.2 & 0 & & 6 \\
\hline $26 N y 5432$ & 0 & & 1 & 50.0 & 0 & & 1 & 50.0 & 0 & & 2 \\
\hline $26 N y 5433$ & 0 & & 0 & & 4 & 66.6 & 2 & 33.3 & 0 & & 6 \\
\hline 26 Ny5434 & 5 & 27.7 & 0 & & 0 & & 13 & 72.2 & 0 & & 18 \\
\hline $26 N y 5435$ & 7 & 18.9 & 2 & 5.4 & 1 & 2.7 & 27 & 72.9 & 0 & & 37 \\
\hline $26 N y 5436$ & 0 & & 0 & 0 & & & 2 & 100.0 & 0 & & 2 \\
\hline 26 Ny5437 & 7 & 7.6 & 1 & 1.0 & 7 & 7.6 & 76 & 82.6 & 1 & 1.0 & 92 \\
\hline 26Ny5438 & 2 & 13.3 & 1 & 6.6 & 1 & 6.6 & 11 & 73.3 & 0 & & 15 \\
\hline $26 N y 5439$ & 3 & 10.0 & 0 & & 4 & 13.3 & 23 & 76.6 & 0 & & 0 \\
\hline 26 Ny5440 & 3 & 9.3 & 0 & & 1 & 3.1 & 28 & 87.5 & 0 & & 32 \\
\hline 26Ny5441 & 8 & 11.1 & 3 & 4.1 & 2 & 2.7 & 59 & 81.9 & 0 & & 72 \\
\hline $26 N y 5442$ & 4 & 28.5 & 2 & 14.2 & 1 & 7.1 & 7 & 50.0 & 0 & & 14 \\
\hline Total & 40 & 11.9 & 11 & 3.2 & 26 & 7.7 & $25 \overline{8}$ & 76.7 & 1 & 0.3 & 336 \\
\hline
\end{tabular}

Key: $\quad n=$ number, $\%=$ percentage based on row count. 
TABLE 8-2. SUMMARY OF DEBITAGE FROM THE 18-03 ROAD SITES.

\begin{tabular}{|c|c|c|c|c|c|c|c|c|c|c|c|}
\hline \multirow[b]{3}{*}{ Site } & \multicolumn{11}{|c|}{ raded Screen Mesh Size } \\
\hline & \multicolumn{2}{|c|}{$>2^{n}$} & \multicolumn{2}{|c|}{$1-2^{n}$} & \multicolumn{2}{|c|}{$1 / 2-1^{\prime \prime}$} & \multicolumn{2}{|c|}{ 1/4-1/2" } & \multicolumn{2}{|c|}{$<1 / 4^{\prime \prime}$} & \multirow{2}{*}{$\begin{array}{r}\text { Total } \\
\mathrm{n}\end{array}$} \\
\hline & $\mathbf{n}$ & $\%$ & $n$ & $\%$ & $n$ & $\%$ & $n$ & $\%$ & $\mathrm{n}$ & $\%$ & \\
\hline 26 Ny5431 & 0 & & 2 & 14.2 & 10 & 71.4 & 2 & 14.2 & 0 & & 14 \\
\hline 26 Ny 5432 & 0 & & 0 & & 1 & 100.0 & 0 & & 0 & & 1 \\
\hline 26 Ny5433 & 0 & & 0 & & 4 & 66.6 & 1 & 16.6 & 1 & 16.6 & 6 \\
\hline 26 Ny5434 & 0 & & 4 & 30.7 & 7 & 53.8 & 2 & 15.3 & 0 & & 13 \\
\hline 26 Ny 5435 & 0 & & 2 & 7.1 & 23 & 82.0 & 3 & 10.7 & 0 & & 28 \\
\hline 26 Ny5436 & 0 & & 0 & & 2 & 100.0 & 0 & & 0 & & 2 \\
\hline 26 Ny 5437 & 2 & 2.4 & 16 & 19.2 & 56 & 67.4 & 8 & 9.6 & 1 & 1.2 & 283 \\
\hline 26 Ny5438 & 0 & & 2 & 16.6 & 7 & 58.3 & 3 & 25.0 & 0 & & 12 \\
\hline 26 Ny5439 & 0 & & 2 & 7.4 & 22 & 81.4 & 2 & 7.4 & 1 & 3.7 & $7 \quad 27$ \\
\hline 26 Ny5440 & 0 & & 4 & 13.7 & 0 & & 9 & 65.5 & 6 & 20.6 & 629 \\
\hline 26 Ny5441 & 0 & & 6 & 9.8 & 38 & 62.2 & 17 & 27.8 & 0 & & 61 \\
\hline 26 Ny5442 & 0 & & 0 & & 8 & 100.0 & 0 & & 0 & & 8 \\
\hline Total & 2 & 0.7 & 38 & 13.3 & 177 & 62.3 & 57 & 20.0 & 9 & 3. & 284 \\
\hline
\end{tabular}

Key: $\quad n=$ number; $\%=$ percentage based on row count

TABLE 8-3. METRIC ATTRIBUTES OF PROJECTILE POINTS FROM THE 18-03 ROAD SURVEY (MM/G).

\begin{tabular}{lccccccccccc}
\hline Site & Ref & Spc & $L$ & $W$ & NW & BW & MSW & SL & BT & ST & WT \\
\hline 5431 & 1 & 1 & - & 26.1 & 20.9 & 19.9 & 26.1 & - & 7.1 & 6.4 & 7.8 \\
5442 & 7 & 1 & - & 30.0 & 19.5 & 19.2 & 30.0 & 16.6 & 8.4 & 5.5 & 8.8 \\
\hline
\end{tabular}

Key: $\quad L=$ length; $W=$ width; $N W=$ neck width; $B W=$ base width; $M S W=$ maximum shoulder width; $S L=s t e m$ length; BT = blade thickness; $S T=$ stem thickness; $W T=$ weight.

cates the bevels. The hydration rim reading on this specimen is 6.5 microns. Specimen 26Ny5442-7-1 exhibits an impact flute snap on the blade and no reworking on the blade or stem. This specimen exhibits the greatest hydration rim reading of all the points with 11.38 microns. This difference may indicate that this obsidian has hydrated at a faster rate because it is not local. Both specimens are weathered.

\section{Summary and Discussion}

For the most part, these sites can be described as obsidian nodule procisrement and reduction localities similar to $26 \mathrm{Ny} 4892$ and
26Ny4894. Debitage comprises $84.4 \%$ $(n=284)$ of the assemblages, followed by cores $(n=40,11.9 \%)$, bifaces $(n=11,3.2 \%)$, and flake tools $(n=1,0.3 \%)$. Obsidian comprises $91.7 \%$ of these collections, followed by silicified tuff and vein opal (8.3\%). Surface remains at site $26 \mathrm{Ny} 4892$ have nearly the same proportions of toolstone: $91.7 \%$ obsidian and $8.2 \%$ silicified tuff and vein opal (Chapter 6 by Amick). However, there are some differences between frequencies of artifact classes at 26 Ny4892 and the 18-03 road sites. Debitage comprises $93.3 \%$ of the $26 \mathrm{Ny} 4892$ assemblage and cores $4.7 \%$. The $18-03$ Road as- 
semblages have higher proportions of cores and relatively fewer flakes. Debitage size classes are comparable to $26 \mathrm{Ny} 4892$, with the exception of the 1-2" class: the 18-03 road sites have a greater proportion (9.7\%) of these flakes.

If large flakes were selected for further reduction at these sites as they appear to have been at 26Ny4892, then debitage proportions should be comparable. The difference in relative proportions may be a reflection of a reductive strategy less intensively focused on flake production in an area with relatively diffuse toolstone. Alternatively, sampling bias may have affected the results.

Three sites are not described as obsidian quarrying localities: 26 Ny5433 contains no flaked artifacts and is dominated by non obsidian debitage, $26 \mathrm{Ny} 5432$ is composed of an obsidian flake and early stage biface, and 26 Ny5436 is comprised of two obsidian flakes.
These sites are probably related to the obsidian procurement activity in the area, but how they are related is not clear.

In summary, of 12 sites investigated along the 18-03 Road, 9 (26Ny5431, 26Ny5434, 26Ny5435, 26Ny5437-5442) are described as obsidian quarrying localities. Apparently, bifacial reduction was not a significant activity in this area as only eight bifaces were recovered from 6 sites. Relative to sites $26 \mathrm{Ny} 4892$ and $26 \mathrm{Ny} 4894$, the sites in this area were not intensively used. The distribution of available toolstone in this area is diffuse, and perhaps the density of artifacts at these sites is a function of toolstone availability. These sites were not fully recorded and were sampled only near the 18-03 Road for mitigation purposes. Therefore, the information that can be derived from these sites is limited. However, comparing these sites to $26 \mathrm{Ny} 4892$ has enabled us to better describe possible prehistoric activities in the vicinity. 


\title{
9. OBSIDIAN HYDRATION ANALYSIS OF THE BUCKBOARD MESA ROAD PROJECT SURFACE COLLECTED ARTIFACTS
}

\author{
Janis Klimowicz
}

In desert areas such as the Great Basin, obsidian hydration analysis is oftentimes the only method available for differentiating discrete archaeological events within and between surface sites. It may be the only method available for establishing chronological control, since many sites in arid regions lack stratigraphy and preserved organic materials for radiocarbon dating. The method can be used to establish the sequence of types of lithic artifacts by providing a relatively large number of readings so that the artifacts in different areas of a single site may be distinguished as being of different or similar ages. In areas of lithic tool manufacture, the relative abundance of obsidian may provide a large sample from which one can determine differences in site usage over a span of time.

The purpose of obsidian hydration analysis of the artifacts from the Buckboard Mesa Road project was not to determine an absolute chronological age for the artifacts, but to examine the relative ages between the artifacts analyzed. Several variables are still uncontrolled in the Buckboard Mesa Road project study, so absolute chronometric ages cannot be attributed to the artifacts that were examined. At the time of this report, sourcing of the obsidian has not been done. Therefore, no exact ages can be assigned to the hydration readings until the obsidian is sourced and the rate at which the specific obsidian hydrates is determined.

\section{Research Design}

Three interrelated facets of the project were examined through hydration analysis. Projectile points were analyzed in an attempt to determine the occupational history of the Buckboard Mesa Road project. Debitagefrom three separate grid units within a single site (26Ny4892) was evaluated to determine a partial chronology of site use. Reworked artifacts were also analyzed, and an evaluation of measurable differences in hydration rim thickness between the initially flaked surface of an artifact and the reworked area on the same side of an artifact was attempted. How these reworked specimens fit into the time frame established for the debitage and the projectile points was of particular interest.

\section{The Hydration Process}

During a study of volcanic glasses, Ross and Smith (1955) discovered that the surface of obsidian undergoes a chemical and physical change known as hydration. That is, newly formed obsidians and freshly exposed obsidian surfaces absorb water from the environment to form a hydrated surface layer that thickens with time. This layer has a greater density and thus a different refractive index than the rest of the mass because of the absorbed moisture. Most obsidians originally contain between $0.1 \%$ to $0.3 \%$ water absorbed during the cooling process, while the hydrated portion alone may contain up to $3.5 \%$ water (Michels and Tsong 1980). This increase in moisture content produces a birefringent strain between the hydrated and nonhydrated portions of the obsidian. Thus, when prepared as a thin section, the hydrated rim can be measured under an optical microscope.

The process of hydration begins each time a fresh surface is exposed to the atmosphere. It continues until the point of saturation has been reached, at which time the mechanical strain between the hydrated and nonhydrated portions may be so great that the hydrated portion spalls off and the process of hydration begins again. Obsidian absorbs atmospheric moisture at fixed rates (varying from source to source) irrespective of the relative humidity of its surroundings. There is enough moisture in any environment to maintain a constant rate of 
hydration. However, besides time, temperature and chemical composition also affect the rate of hydration.

Temperature is an important variable which is difficult to control in archaeological sites. A greater mean temperature increases the rate at which obsidian hydrates. Ambrose (1976) and Michels (1973) state that each one-degree-centigrade increase in ambient temperature results in an approximate $10 \%$ change in the rate of hydration, suggesting that hydration is indeed very sensitive to temperature fluctuations over a period of time.

Since it was discovered early on in hydration studies that the chemical constituency of different obsidian flows affects hydration rates, much of the focus of hydration studies has turned to sourcing different obsidians. As an example of chemical sensitivity, Ambrose (1976) noted that certain chemical components such as sodium, potassium, and hydroxyl have a positive effect on hydration, while others such as iron and calcium tend to reduce the rate of hydration. Based on the work being done on the chemical sourcing of obsidian, and the air and surface temperatures at different sites, it has been noted that the rates of hydration between sources can vary as much as one micron per 160 years to one micron per 1000 years (Clark 1984; Friedmar, 1968; Hughes 1988; Meighan and Haynes 1970; Stevenson, Carpenter, and Scheetz 1989). Bowman, Asaro, and Perlman (1973) also note that an individual obsidian flow can show considerable variation in chemical composition, indicating that the rate of hydration may also vary within a single flow.

See Ericson, Mackenzie, and Berger (1976), Friedman and Smith (1960), Jackson (1984), Michels (1973), Michels and Tsong (1980), and Ross and Smith (1955) for a more complete and technical discussion on the process of hydration.

\section{Analytical Procedures}

\section{Debitage}

Sixty obsidian flakes from $26 \mathrm{Ny} 4892$ were submitted for hydration analysis, representing three spatially separate areas. Twenty flakes were chosen from each surface collection grid unit (890N 1160E, 980N 860E, and 1190N 1000E). Prepared slides are curated at the Desert Research Institute, Quaternary Sciences Center, Obsidian Hydration Laboratory (DRIQSC-OHL) under specimen accession numbers QSC/OHL-1-40 and QSC/OHL-47-66.

\section{Projectile Points}

Eighteen typable projectile points and four projectile point fragments from four separate sites from the Buckboard Mesa Road project were submitted for hydration analysis. All specimens were surface finds. Table 9-1 shows the sites and the associated projectile points submitted. Prepared slides are curated at the DRI-QSC-OHL under specimen accession numbers QSC/OHL-105-124 and QSC/ OHL-126-130.

\section{Reworked Artifacts}

Seventeen reworked specimens from 26Ny4892 were submitted for hydration analysis. Two cuts were made on each specimen, producing a total of 34 prepared thin sections. The first cut was made on the initially flaked surface; the second was made on a surface showing later, more recent working. The prepared slides are curated at the DRI-QSC-OHL under specimen accession numbers QSC/ OHL-67-88 and QSC/OHL-93-104.

\section{Methodology}

All specimens were initially examined for surface abrasion and patination, factors which could have removed a portion of the hydrated surface. The surface condition of an artifact was noted in the data records. A thin section location was deemed appropriate if it had a flake scar on at least one surface. Two parallel cuts were made approximately $2 \mathrm{~mm}$ apart 
TABLE 9-1. OBSIDIAN PROJECTILE POINT DISTRIBUTION BY SITE.

\begin{tabular}{llc}
\hline Site & Series & Frequenc; \\
\hline 26 Ny4875 & Gatecliff & 1 \\
26 Ny4892 & Desert Side-notched & 1 \\
& Rosegate & 4 \\
& Gateciff & 3 \\
& Pinto & 1 \\
& Humboldt & 1 \\
& Great Basin Stemmed & 2 \\
& Medium Sidenotched & 1 \\
& Indeterminate Biturcate Base & 4 \\
26 Fy5431 & Fragments & 2 \\
26 Ny5442 & Great Basin Stemmed & 1 \\
\hline
\end{tabular}

and 4-5 $\mathrm{mm}$ deep at an appropriate location along the edge of each specimen with a 4-inch, diamond-impregnated, circular blade mounted on a lapidary trim saw.

The wedge created by these cuts was then removed and initially ground down using 600-grit silicon-carbide abrasive to eliminate the microchipping and pitting which occurs during the cutting process, and to thin the specimen. The specimen was then mounted onto a standard petrographic microscope slide using Lakeside cement with the freshly ground surface mounted against the slide. It was ground down until a final thickness of between 30 to 50 microns was reached. When the thinning process was completed, a protective glass coverslip was applied.

The sections were then examined using a Nikon petrographic optical microscope. The rim and edge on each specimen were initially examined using a 100-power objective, oil immersion lens, after which time the hydration rims were measured using a 100-power objective, oil immersion lens with a 10x Nikon filar micrometer attachment eyepiece. An inherent measurement error of \pm 0.2 microns, is present on every reading because of the optical limitations of the microscopy (Michels 1965; Scheetz and Stevenson 1988).

Four measurements were taken along each edge of the four specimens that had two edges with hydration rims for a total of eight measurements. An attempt was made to apply a two-sample, two-tailed difference of means $t$-test to determine the probability that the differences between readings on both surfaces are chance occurrences (e.g., Jackson 1985). However, since the sample sizes were small, the statistical results may not be reliable. Other statistical applications were attempted, but again the small sample sizes make their meaning unclear. In most cases, the individual edges of the thin sections were not treated as unique entities. The means for both edges were combined for each specimen as reported in Tables 9-2 and 9-3 for the debitage and the projectile points. The only comparison of single-sided measurements are from the reworked specimens where the means from the dorsal or ventral sides have been correlated, as shown in Table 9-4. 
TAB:-E G-2. SUMMARY OF OBSIDIAN HYDRATION DATA FOR 26NY4892 DEBITAGE. LEVEL OF MAGNIFICATION IS 1000X. (Measurements in Microns.)

\begin{tabular}{|c|c|c|c|c|}
\hline $\begin{array}{l}\text { Reference } \\
\text { Number" }\end{array}$ & $\begin{array}{l}\text { OHL } \\
\text { Number }\end{array}$ & $\begin{array}{l}\text { Artifact } \\
\text { Type }\end{array}$ & $\begin{array}{l}\text { Mean Rin } \\
\text { Thicknes } \\
\text { mean Std De }\end{array}$ & \\
\hline $\begin{array}{l}797-01 \\
797-02 \\
797-02 \\
797-03 \\
797-03 \\
797-03 \\
797-04 \\
797-04 \\
797-05 \\
797-05 \\
797-06 \\
797-07 \\
797-07 \\
797-07 \\
797-09 \\
797-10 \\
797-11 \\
797-12 \\
797-13 \\
797-14 \\
1025-01 \\
1025-01 \\
1025-02 \\
1025-03 \\
1025-04 \\
1025-05 \\
1025-05 \\
1025-06 \\
1025-06 \\
1025-06 \\
1025-07 \\
1025-07 \\
1025-07 \\
1025-08 \\
1025-09 \\
1025-10 \\
1025-11 \\
1025-11 \\
1025-12 \\
1025-12 \\
11201-3 \\
1120-14 \\
1120-14 \\
1120-15 \\
1120-15 \\
11201-6 \\
1120-17 \\
1120-17 \\
1120-18 \\
1120-19 \\
1120-20 \\
1120-21 \\
1120-21 \\
1120-23 \\
1120-24 \\
1120-25 \\
1120-25 \\
1120-26 \\
1120-27\end{array}$ & $\begin{array}{l}01 \\
02 \\
03 \\
04 \\
05 \\
06 \\
07 \\
08 \\
09 \\
10 \\
11 \\
12 \\
13 \\
14 \\
15 \\
16 \\
17 \\
18 \\
19 \\
20 \\
21 \\
22 \\
23 \\
24 \\
25 \\
26 \\
27 \\
28 \\
29 \\
30 \\
31 \\
32 \\
33 \\
34 \\
35 \\
36 \\
37 \\
38 \\
39 \\
40 \\
48 \\
49 \\
50 \\
51 \\
52 \\
53 \\
54 \\
55 \\
56 \\
57 \\
58 \\
59 \\
60 \\
61 \\
62 \\
63 \\
64 \\
65 \\
66\end{array}$ & $\begin{array}{l}\text { flake } \\
\text { flake } \\
\text { flake } \\
\text { flake } \\
\text { flake } \\
\text { flake } \\
\text { flake } \\
\text { flake } \\
\text { flake } \\
\text { flake } \\
\text { flake } \\
\text { flake } \\
\text { flake } \\
\text { flake } \\
\text { flake } \\
\text { flake } \\
\text { flake } \\
\text { flake } \\
\text { flake } \\
\text { flake } \\
\text { flake } \\
\text { flake } \\
\text { flake } \\
\text { flake } \\
\text { flake } \\
\text { flake } \\
\text { flake } \\
\text { flake } \\
\text { flake } \\
\text { flake } \\
\text { flake } \\
\text { flake } \\
\text { flake } \\
\text { flake } \\
\text { flake } \\
\text { flake } \\
\text { flake } \\
\text { flake } \\
\text { flake } \\
\text { flake } \\
\text { flake } \\
\text { flake } \\
\text { flake } \\
\text { flake } \\
\text { flake } \\
\text { flake } \\
\text { flake } \\
\text { flake } \\
\text { flake } \\
\text { flake } \\
\text { flake } \\
\text { flake } \\
\text { flake } \\
\text { flake } \\
\text { flake } \\
\text { flake } \\
\text { flake } \\
\text { flake } \\
\text { flake }\end{array}$ & $\begin{array}{l}2.88 \pm \\
\text { NVH } \\
3.25 \pm \\
2.88 \pm \\
1.88 \pm \\
2.83 \pm \\
1.97 \pm \\
1.67 \pm \\
\text { NVH } \\
3.45 \pm \\
4.50 \pm \\
3.77 \pm \\
5.03 \pm \\
3.45 \pm \\
3.30 \pm \\
1.63 \pm \\
1.93 \pm \\
1.37 \pm \\
2.83 \pm \\
2.56 \pm \\
2.25 \pm \\
3.48 \pm \\
3.25 \pm \\
1.87 \pm \\
3.50 \pm \\
1.48 \pm \\
\text { NVH } \\
1.50 \pm \\
1.92 \pm \\
1.67 \pm \\
1.65 \pm \\
1.67 \pm \\
1.70 \pm \\
1.82 \pm \\
1.40 \pm \\
1.48 \pm \\
1.38 \pm \\
2.03 \pm \\
1.23 \pm \\
2.17 \pm \\
2.90 \pm \\
2.68 \pm \\
2.08 \pm \\
2.40 \pm \\
2.00 \pm \\
3.48 \pm \\
2.38 \pm \\
2.65 \pm \\
2.20 \pm \\
2.60 \pm \\
2.40 \pm \\
1.62 \pm \\
2.10 \pm \\
2.18 \pm \\
\text { N } \\
1.23 \pm \\
3.10 \pm \\
1.90 \pm \\
\pm\end{array}$ & $\begin{array}{l}.6 \\
.5 \\
.4 \\
.3 \\
.7 \\
.5 \\
.3 \\
.8 \\
.4 \\
.6 \\
.7 \\
.5 \\
.6 \\
.2 \\
.8 \\
.2 \\
.6 \\
.8 \\
.4 \\
.9 \\
.4 \\
.6 \\
.2 \\
.3 \\
.2 \\
.3 \\
.3 \\
.3\end{array}$ \\
\hline
\end{tabular}

Key: $=$ NVH $=$ No Visible Hydration Rim; OHL = Obsidian Hydration Laboratory; $=$ Reference Number 797 is grid unit 890N $1160 E ; ~ *$ $=$ Reference Number 1025 is grid unit $980 \mathrm{~N} 8 \mathrm{COE}$; " = Reference Number 1120 is arid unit $1190 \mathrm{~N} 1000 \mathrm{E}$ 
TABLE 9-3. SUMMARY OF OBSIDIAN HYDRATION DATA. FOR PROJECTILE POIN IS FROM THE BUCKBOARD MESA ROAD PROJECT. (Measurements in Microns.)

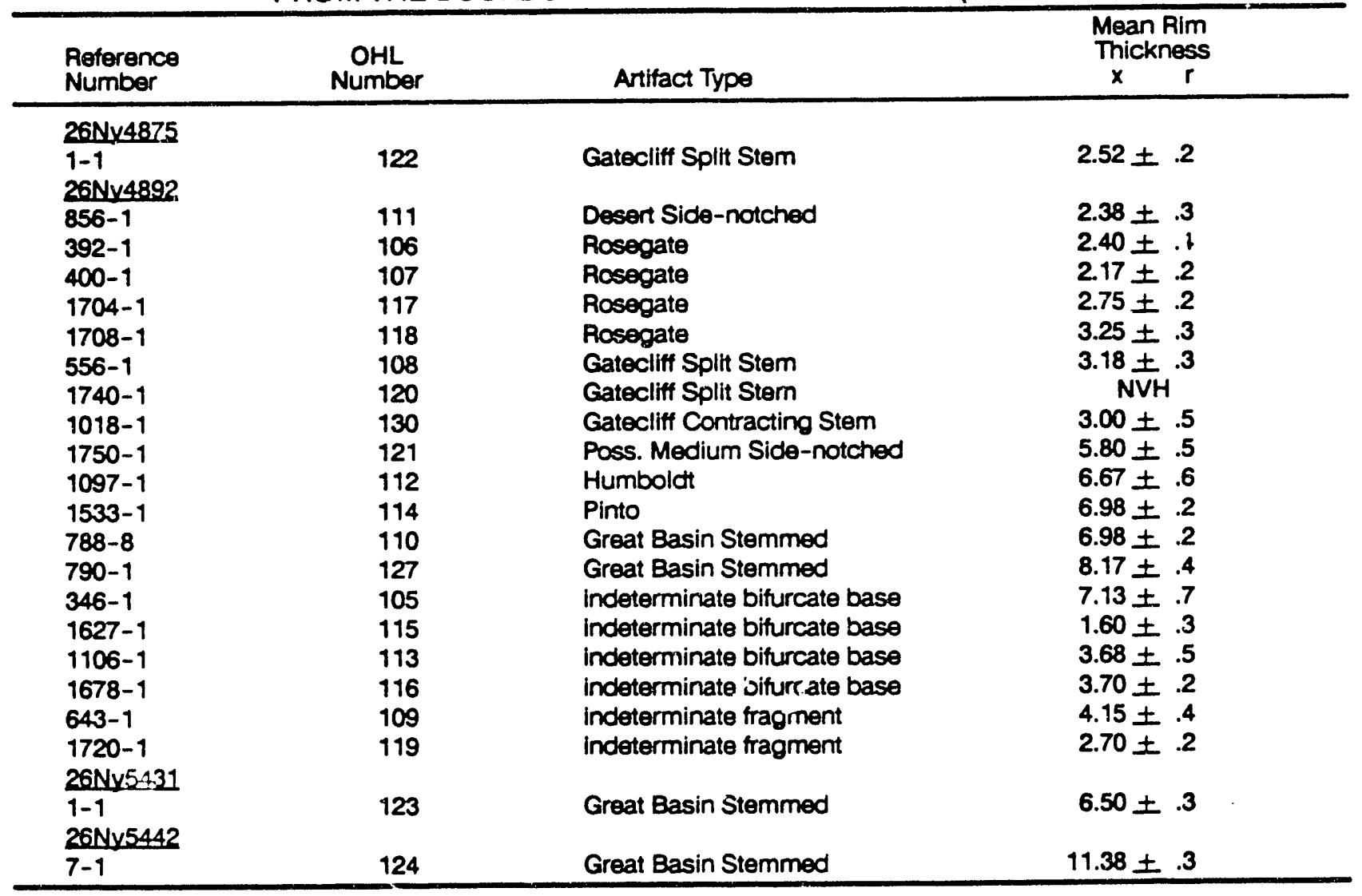

Koy: $\quad$ NVH $=$ No Visible Hydration Rim: OHL = Obsidian Hydration Laboratory

TABLE 9-4. SAMESIDE COMPARISONS OF HYDRATION RIMS FOR REWORKED AFITIFACTS FROM 26NY4892. (Measurements in Microns.)

\begin{tabular}{|c|c|c|c|c|c|}
\hline $\begin{array}{l}\text { Reference } \\
\text { Number }\end{array}$ & $\begin{array}{l}\text { OHL } \\
\text { Number }\end{array}$ & $\begin{array}{l}\text { Heavily } \\
\text { Weathered } \\
\text { Surface }\end{array}$ & $\begin{array}{l}\text { Lightly } \\
\text { Weathered } \\
\text { Surface }\end{array}$ & $\begin{array}{l}\text { Fresh } \\
\text { Surtace } \\
\text { (Unweathered) }\end{array}$ & $\begin{array}{l}\text { Later } \\
\text { Fresh } \\
\text { Surface }\end{array}$ \\
\hline $\begin{array}{l}236-2 \\
264-14 \\
747-6 \\
785-26 \\
789-7 \\
825-11 \\
909-10 \\
918-4 \\
939-7 \\
1007-5 \\
1050-6 \\
1175-1 \\
1197-1 \\
1217-1 \\
1232-1 \\
1484-1 \\
1507-1\end{array}$ & $\begin{array}{l}71-72 \\
67-68 \\
73-74 \\
69-70 \\
95-96 \\
97-98 \\
99-100 \\
77-78 \\
79-80 \\
101-102 \\
81-82 \\
83-84 \\
75-76 \\
103-104 \\
85-86 \\
87-88 \\
93-94\end{array}$ & $\begin{array}{l}7.7 \\
1.9 \\
4.5 \\
2.1 \\
2.1 \\
2.7 \\
2.4 \\
2.3 \\
\text { NVH } \\
2.4 \\
5.3 \\
\\
3.1 \\
3.1 \\
4.0 \\
4.5\end{array}$ & 2.7 & $\begin{array}{l}\text { NVH } \\
3.8 \\
2.4 \\
2.3 \\
1.7 \\
1.3 \\
1.6 \\
2.2 \\
2.4 \\
2.3 \\
\text { NVH } \\
1.8 \\
\\
3.1 \\
2.7 \\
2.8 \\
3.2 \\
1.3\end{array}$ & $\begin{array}{l}1.7 \\
3.0\end{array}$ \\
\hline
\end{tabular}

Key: $\quad$ NVH = No Visible Hydration Rim; OHL = Obsidian Hydration Laboratory 


\section{Analysis of the Occupational History}

Several key factors may affect the rate of hydration of the obsidian at the Buckboard Mesa Road project. Since ambient temperature is greatly affected by altitude, for example, elevation has been suggested as one of the factors that may alter the rate of hydration in Great Basin obsidian artifacts. Meighan (1981:221) notes that preliminary unpublished studies document a marked slowing of obsidian hydration at higher elevations, possibly the result of lower temperatures. The average elevation for the project area is approximately $5400 \mathrm{ft}$. While the variation in elevation between the different sites examined through hydration analysis is estimated at $\pm 80 \mathrm{ft}$, it is assumed that this degree of difference in elevation would not significantly affect the individual rates of hydration.

Vegetation cover is another factor which may influence hydration rates since vegetation influences the microclimate where the obsidian is located. The vegetation cover in the project area has been estimated at approximately $25 \%$, which suggests that solar exposure would have been relatively high for all of the artifacts. Also, because all artifacts were located on south-facing slopes their rates of hydration should be similar. Southern exposure would result in a relatively higher surface temperature, as compared to other slopes, and may mean that these artifacts hydrated at a faster rate than if they had been buried. Since all artifacts were surficial they may have been exposed to eolian processes as well. Since exposure and elevation among the artifact classes are all similar, the local conditions may have affected all artifacts equally. However, some of the hydration readings may be misleading, and assumptions about relative ages should be made with caution since the hydration rims on dorsal and ventral surfaces may not be equal, possibly due either to eolian erosion or to the mechanics of thin section preparation. Since these factors cannot be controlled, the hydration measurements from the two sides are averaged, and the mean is assumed to be the most accurate measurement. In the case of the reworked artifacts, only a single side is examined.

Michels and Tsong (1980:411) suggest using hydration measurements as an unbiased procedure for segregating artifacts (from surface sites or from poorly stratified or unstratified subsurface deposits) into analytically useful units of association. They propose establishing arbitrary micron ranges and treating all hydration values falling within each of those ranges as being associated in some definable sense. For this study, arbitrary units each containing a range of 0.5 microns have been established. The first unit contains all hydration values of 1-1.4 microns, the second 1.5-1.9 microns, and so on up to $11.0-11.4$ microns, producing 21 separate divisions.

\section{Projectile Points}

Projectile points from four sites were submitted for hydration analysis. The sites and number of artifacts submitted were as follows; 26 Ny4875 $(n=1), 26$ Ny4892 $(n=19), 26$ Ny5431 $(n=1)$, and $26 \mathrm{Ny} 5442(n=1)$. The hydration measurements from 14 projectile points from these sites are plotted in Figure 9-1. The remainder of the artifacts were not plotted. Two are considered indeterminate (untypable) fragments. These include QSC/OHL-109 and 119 (Table 9-3). Additional artifacts not included in Figure 9-1 consist of four artifacts classified as indeterminate bifurcate base projectile points, (QSC/OHL-105, 113, 115, and 116), and one artifact which had no visible hydration rim (QSC/OHL-120).

The projectile point analysis roughly calibrates time for the hydration measurements through cross-dating. However, since sourcing of the obsidians was not done at this site. no precise chronological time can be assigned to the hydration measurements. A comparison of the hydration rims among the debitage, the reworked artifacts, and the projectile points may be justified since the depositional history was probably very similar for these artifact 


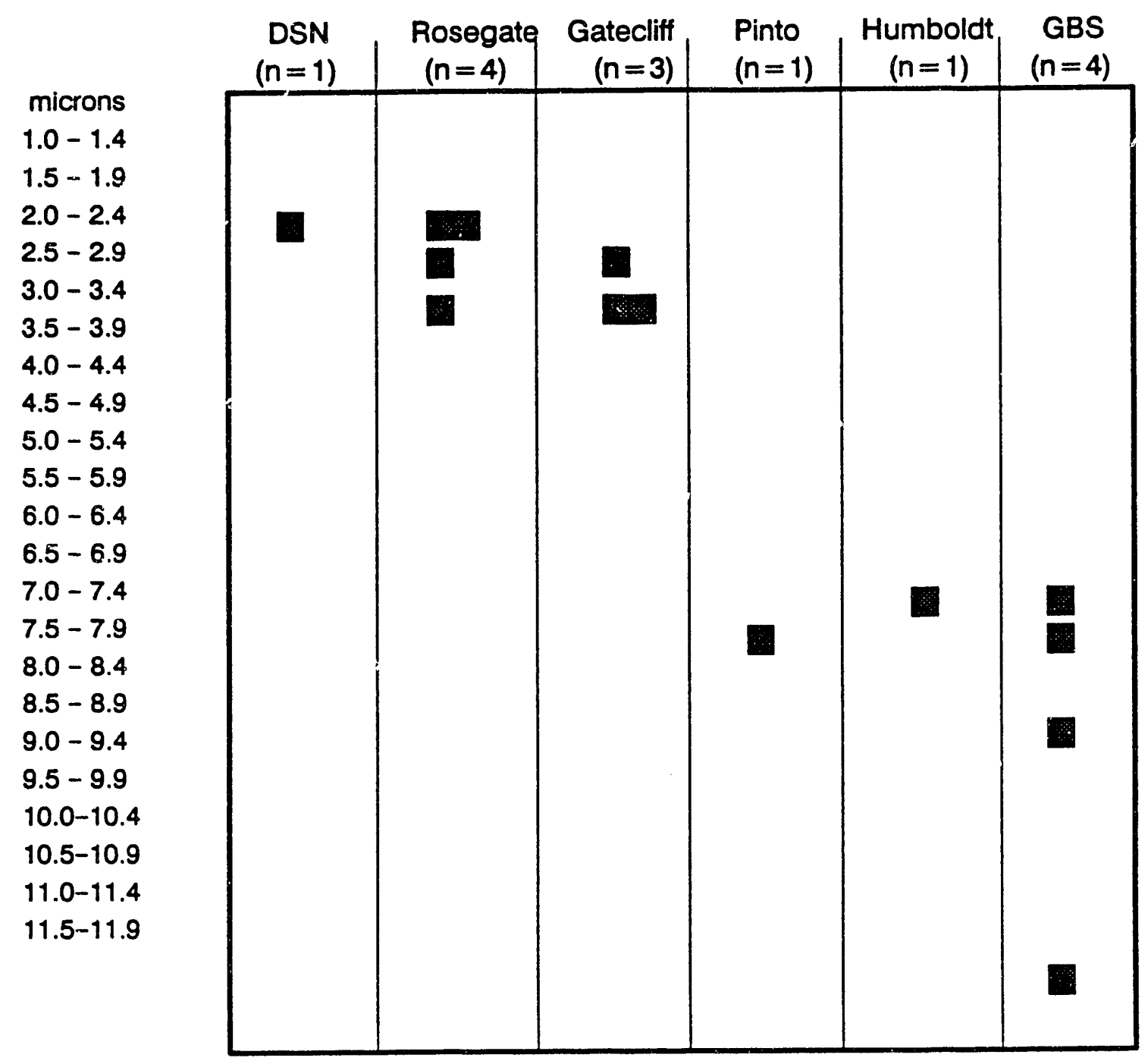

Figure 9-1. Summary of obsidian hydration data for projectile points from the Buckboard Mesa Road project.

classes. The projectile points were surface finds, so they have undergone environmental conditions similar to the debitage and reworked artifacts.

These results are tentative because only a small number of projectile points were analyzed. However, the general trend presented in Figure $9-1$ is suggestive of point chronologies presented by Elston (1982), Jennings (1986), Lyneis (1982b), and Thomas (1982) and may range from about 10,000 years to historic times.

\section{Debitage}

Samples from three different grid units within a single site (26Ny4892) were examined to determine if each grid unit was the result of a discrete archaeological event, and to determine the archaeological relationships between the grid units. The areas were selected on the basis of artifact density. A grid unit was deemed sutficient as a sample if it had a minimum of 20 obsidian flakes to submit for hydration analysis. Therefore, three areas with high concentrations of debitage were selected. 
Grid unit $890 \mathrm{~N} 1160 \mathrm{E}$ was located at an elevation of approximately 5462 feet on a south facing siope. Grid unit $980 \mathrm{~N}$ 860E was located at an elevation of approximately 5460 feet on a steep south facing slope. Grid unit $1190 \mathrm{~N}$ 1000E was located at approximately 5475 feet on a slope facing south southeast (Figure 6-1). The variation in elevation of 15 feet between the grid units at $26 \mathrm{Ny} 4892$ is probably insignificant.

Table 9-2 summarizes the information gathered on the 60 flakes submitted for hydration analysis. A combined mean and standard deviation for the eight individual hydration readings is shown for each specimen. Seventy percent $(n=42)$ of the sample have hydration rims visible on both sides while $22 \%$ $(n=13)$ have rims visible on only one side. Ninety-two percent have a rim visible on at least one side of the thin section. This may be due to either eolian erosion or the mechanics of thin section preparation. Five of the specimens (QSC/OHL-14-17, 23) have abnormally large hydration bands on one side due to the presence of cortex. The cortical measurements are not included in the mean rim measurements.

If the frequency of mean distribution for each of the three areas of concentration is examined, it is evident that for two of the areas of concentration (grid units $980 \mathrm{~N} 860 \mathrm{E}$ and $1190 \mathrm{~N}$ 1000E) there appear to be temporally limited occupation(s) The third area (grid unit $890 \mathrm{~N} 1160 \mathrm{E}$ ) appears to reflect a history of reoccupation for this portion of the site (Figure 9-2). It must be remembered, however, that the grid units are imposed collection areas that may or may not have anything to do with the actual distribution of debitage. The reduction sequences represented by the debitage may have been bisected by grid units which would tend to give an incomplete picture of the relative seriation of the area as portrayed through the obsidian hydration measurements.

Hydration measurements fall into 8 of the 21 divisions, bit are concentrated within the first 6 ranges; $1.0-1.4$ microns, $1.5-1.9 \mathrm{mi}-$ crons, 2.0-2.4 microns, 2.5-2.9 microns, 3.0-3.4 microns, and 3.5-3.9 microns. The modal rim thickness for grid unit $980 \mathrm{~N} 860 \mathrm{E}$ assemblage is in the 1.5-1.9 micron range, indicating that it may be the most recently utilized of the three areas examined. The hydration measurements suggest that obsidian reduction near grid unit $1190 \mathrm{~N} 1000 \mathrm{E}$ was increasing at about the time that obsidian reduction near grid unit $980 \mathrm{~N} 860 \mathrm{E}$ was dropping off. The debitage associated with grid number $890 \mathrm{~N} 1160 \mathrm{E}$ has a relatively low but steady accumulation that indicates that it was used roughly contemporaneously with the other two areas studied, but this area was also used later. This scattered distribution of hydration measurements indicates that obsidian reduction in this area may always have been relatively low. It appears that grid units $1190 \mathrm{~N} 1000$ and $980 \mathrm{~N} 860 \mathrm{E}$ both represent a single reduction episode while grid unit $890 \mathrm{~N} 1160 \mathrm{E}$ may represent several small reduction episodes.

As demonstrated here, hydration analysis has allowed the assignment of a relative time frame to obsidian exploitation at $26 \mathrm{Ny} 4892$. This chronological dimension allows reconstruction of the depositional history and prehistoric occupation of the area.

If measurements from the debitage are considered in light of the projectile point chronology, it appears that local obsidian reduction occurred relatively recently and probably represents extensive exploitation since the last 3000 years. Debitage from grid unit $980 \mathrm{~N}$ $860 \mathrm{E}$ is the most recent and may represent debris from about 1000 years ago when Desert Side-notched points were in use. The bulk of debris from grid unit $1190 \mathrm{~N} 1000 \mathrm{E}$ was created later in time, possibly between 1000 and 2000 years ago when Rosegate projectile points and more recently when Desert Side-notched projectile points were in use. Debitage from grid unit $890 \mathrm{~N} 1160 \mathrm{E}$ shows manufacture over an extended period of time, possibly covering the last 3000 years. Obsidian reduction near 
Grid Unit $890 \mathrm{~N} 1160 \mathrm{E}(n=18)$

frequency

microns

123456789101112131415

$1.0-1.4$

$1.5-1.9$

$2.0-2.4$

$2.5-2.9$

$3.0-3.4$

$3.5-3.9$

$4.0-4.4$

$4.5-4.9$

$5.0-5.9$

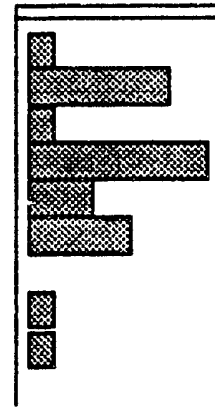

Grid Unit 980N 860E $(n=18)$

frequency

microns

123456789101112131415

$1.0-1.4$

$1.5-1.9$

$2.0-2.4$

$2.5-2.9$

$3.0-3.4$

$3.5-3.9$

$4.0-4.4$

$4.5-4.9$

$5.0-5.9$

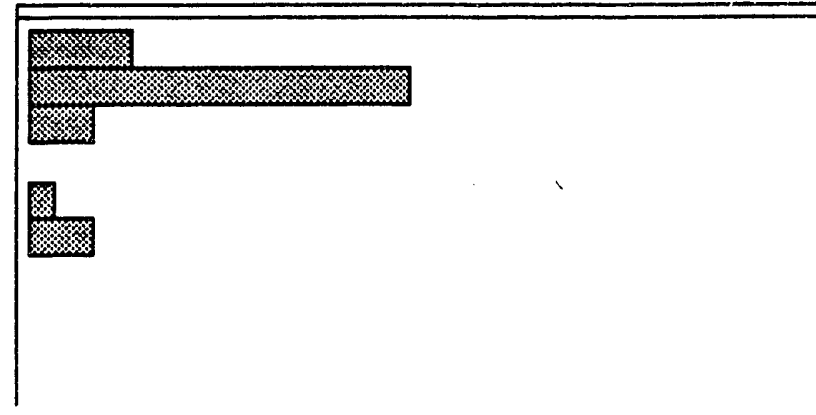

Grid Unit 1190N 1000E $(n=18)$

frequency

microns

123456789101112131415

$1.0-1.4$

$1.5-1.9$

$2.0-2.4$

$2.5-2.9$

$3.0-3.4$

$3.5-3.9$

$4.0-4.4$

$4.5-4.9$

$5.0-5.9$

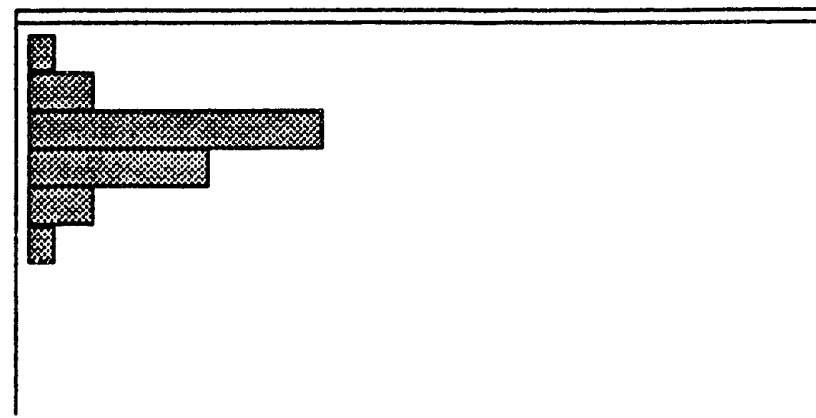

Figure 9-2. Obisidian hydration measurements of surface debitage from $26 \mathrm{Ny} 4892$ frequency distribution based on 0.5 micron units). 
grid unit $890 \mathrm{~N} 1160 \mathrm{E}$ was probably occurring when Gatecliff projectile points were in use, about 3000 years ago, and again more recently when Rosegate projectile points and Desert Side-notched projectile points were in use.

\section{Reworked Arkifacts}

Seventeen reworked artifacts were examined to determine if obsidian hydration could suggest the amount of time that might have elapsed between the separate episodes of flake removal. An artifact was deemed "reworked" if a more recent flake scar had intersected an earlier flake scar. In all instances there was weathering on the older surface which may have obliterated a portion of the hydrated rim. More recent flake scars appeared fresher than the earlier flake scars, which had a dull finish.

Each artifact had two separate samples taken for hydration analysis, one from the originally flaked surface and the second from the more recently flaked surface. Notations were made on the orientation of the section on the microscope slide so that the same surface of an artifact (dorsal or ventral) could be compared between the two samples.

It was expected 1) that hydration readings on the original flake scar would be greater than the more recent flake scar and 2) chance alone would account for hydration readings on the older flaked surface being less than or equal to the hydration readings on the more recently flaked surface in approximately half of the cases. To test this proposition, the hydration measurements from two thin sections from the same artifact were compared. The comparison was made between thin sections from the same surface of the artifact.

After the specimens with no visible hydration rims were omitted, sixteen comparisons were made (Table 9-4). If an assumed error of \pm 0.4 microns was imposed on the sample, the percentage of the sample supporting the proposition is only $56 \%(n=9)$. The remaining $44 \%(n=7)$ showed hydration readings on the older surface which were greater than or equal to the younger surface. The comparisons between the individual measurements do not show a great deal of difference. One of the major factors that may have affected the hydration rims could have been weathering. This might have diminished the rims on the earlier flaked surfaces, thereby reducing the time span between the earlier and later flaked surfaces. The sample size of reworked artifacts is small, so the results are only tentative. It is hoped that in the future other sites will yield reworked artifacts that may be added to this comparison.

The frequency distribution of the reworked artifacts has been classed into two categories. The first contains the fresh unweathered surface measurements and results from the more recent flaking episodes; the second contains the heavily weathered surface category. If this distribution (Figure 9-3) is compared to the debitage and the projectile points, some idea of the possible age of the two separate flaking sequences is evident. The fresh unweathered surface may represent flaking that occurred relatively recently in time, perhaps 1000 to 3000 years ago when Gatecliff, Rosegate and later Desert Side-notched projectile points were in use. The more heavily weathered surface seems to have two separate distributions, the majority of the flake scars belonging in the period from 1000 to 3000 years ago, similar to the age of the fresh, unweathered surfaces. However, a small number $(n=5)$ date much earlier and may belong in the Hunivoldt, Pinto, and Gatecliff periods.

\section{Conclusion}

Obsidian hydration is an important tool for establishing occupational history at surface sites. Several facets of site formation have been examined. Hydration studies show that the debitage from the individual grid units was not necessarily created as a single occupational event. Rather, grid unit $890 \mathrm{~N} 1160 \mathrm{E}$ shows a gradual increase over time, grid unit $1190 \mathrm{~N} 1000 \mathrm{E}$ shows a steady increase and a steady decline of deposition, and the remain- 
Fresh Surface (unweathered) $(n=16)$

frequency

microns 123456789101112131415

$1.0-1.4$
$1.5-1.9$
$2.0-2.4$
$2.5-2.9$
$3.0-3.4$
$3.5-3.9$
$4.0-4.4$
$4.5-4.9$
$5.0-5.9$

Heavily weathered surface $(n=16)$

frequency

microns

123456789101112131415

$1.0-1.4$

$1.5-1.9$

$2.0-2.4$

$2.5-2.9$

$3.0-3.4$

$3.5-3.9$

$4.0-4.4$

$4.5-4.9$

$5.0-5.9$

$6.0-6.4$

$6.5-6.9$

$7.0-7.4$

$7.5-7.9$

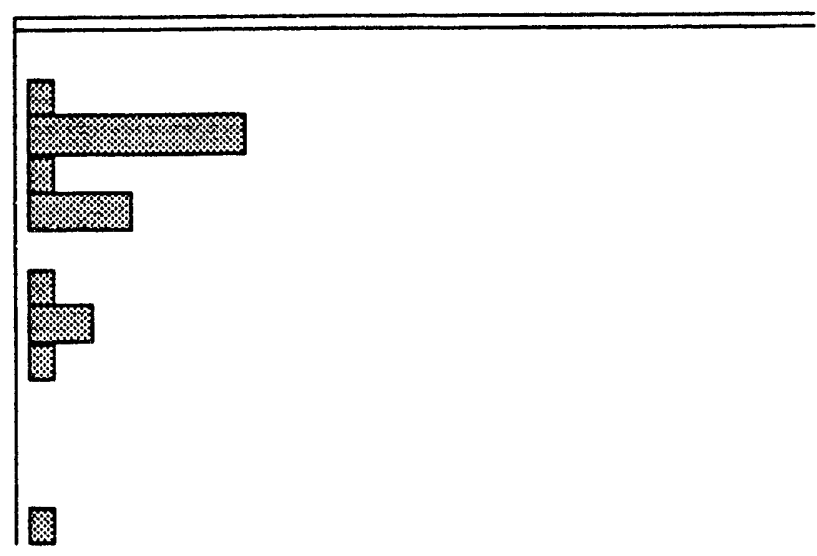

Figure 9-3. Frequency distribution of reworked artifacts from 26 Ny4892.

ing grid unit, $980 \mathrm{~N} 860 \mathrm{E}$, shows what was probably a single flaking episode. To gain chronological control over the grid units, the hydration measurements were compared to those from the projectile points. Since the sample size of the projectile points was so small, and, since no sourcing of the possibly different obsidians deposited in the site was done, the results remain tentative. The direction of the projectile point measurements, when compared to Jennings (1986), did generally follow his chronology for projectile point types. As with the projectile points, the reworked artifacts were represented by few specimens, so conclusions from their measurements also remain tentative until the sample size can be increased and sourcing can be done.

The relatively thin hydration band measurements may suggest that this site was occupied relatively recently in time. As Figure 9-4 indicates, the majority of the artifacts examined occur in the 1.0-3.9 micron range, which, as suggested earlier, represents about the last 3,000 years of history. The small size of local obsidian nodules probably discouraged exploitation until a time when projectile points 
and tools were relatively smaller than during earlier periods. Sourcing of the obsidians is needed to evaluate this proposition since a comparison can then be made between the ar- tifacts which fall into the 1.0-3.9 micron range and those that fall into the 4.0-11.4 micron range as indicated in Figlire 9-4.

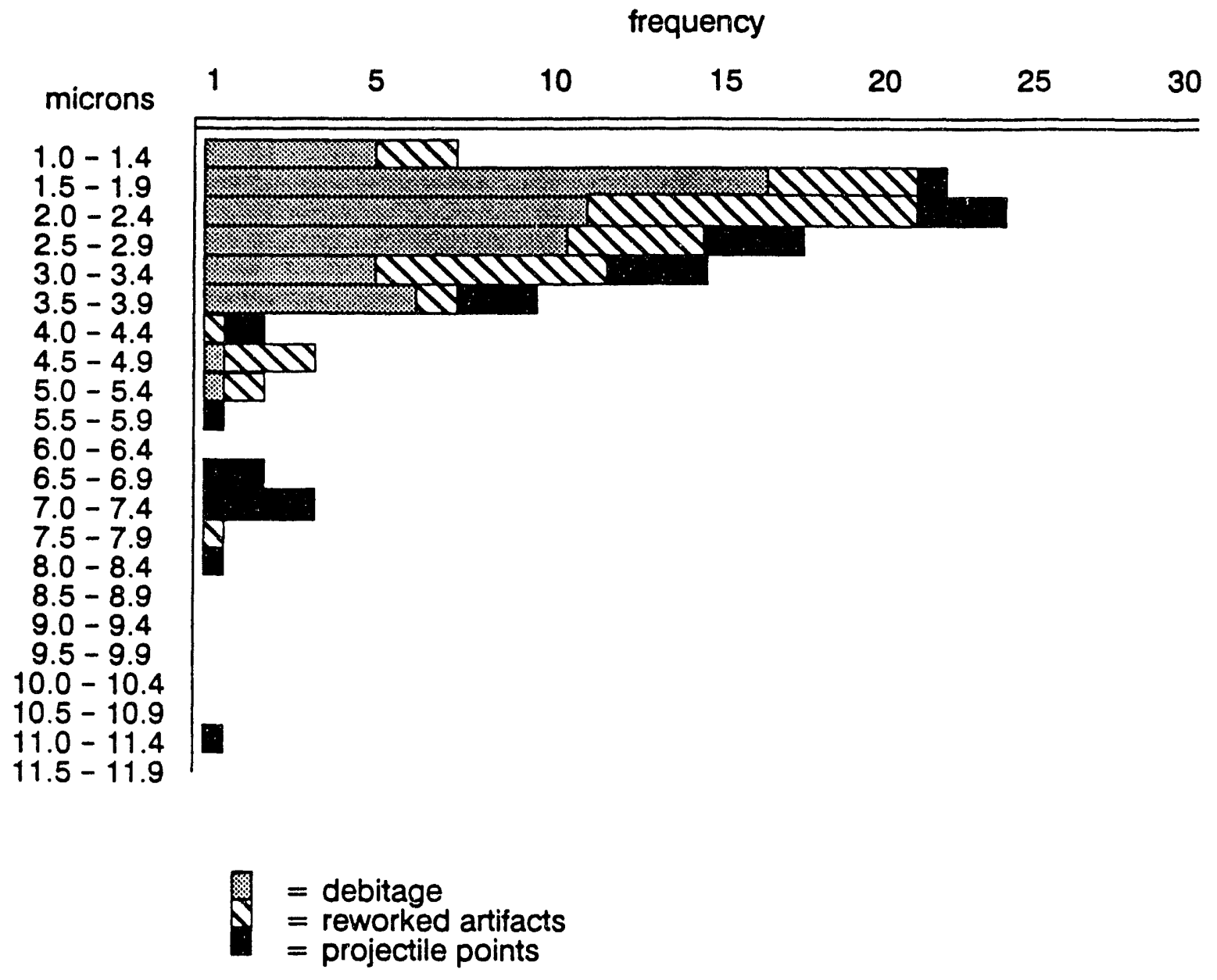

Figure 9-4. Summary of all hydration measurements from the Buckboard Mesa Road project. 


\title{
10. SUMMARY AND CONCLUSION
}

\author{
Daniel S. Amick
}

The investigations at $26 \mathrm{Ny} 4892$ have presented several interesting archaeological implications which relate to spatial patterning, temporal patterning, technological behavior, technological analysis, and regional land-use patterns. The bulk of the evidence from 26Ny4892, 26Ny4894, and the 18-03 Road sites suggests that collection and reduction of obsidian nodules was the primary activity conducted at these locations. This activity appears to have been conditioned by the distribution of obsidian nodules, and these toolstone resources appear to have been exploited to near exhaustion.

Prehistoric occupation seems to have occurred throughout the last 10,000 years. Activities during early Holocene times (GBS and Pinto periods) seem related to other evidence of intense general use of Fortymile Wash by these peoples (Henton and Pippin 1988). Obsidian hydration evidence indicates that limited obsidian nodule quarrying occurred during the early Holocene. The obsidian trace element data for projectile points and flakes from other sites in Fortymile Wash provide a starting point for investigating this issue. Although an analysis which relates the artifact trace element data to obsidian sources is needed, these data are not currently available. Future sourcing work should be accomplished to remedy this problem. Despite the lack of source data, it may be possible to determine the degree to which the artifacts resemble each other in trace element composition and explore the potential that trace element analysis may have for future source discrimination.

The data presented in Pippin (1984:Table 5) were assembled as a matrix with 51 cases (artifacts) and 7 variables (trace elements in ppm). Table 10-1 presents factor scores for a varimax rotated solution which reduced the seven elements to three dimensions which account for $90.1 \%$ of the total variability. Factor 1 accounts for $55.2 \%$ of the total variability and is bipolar with a high negative loading on strontium (Sr) and high positive loadings on the elements yttrium ( $M$, zirconium $(\mathrm{Zr})$, and niobium (Nb). Factor 2 accounts for an additional $22.4 \%$ of the variability and has high positive loadings on lead $(\mathrm{Pb})$ and rubidium ( $\mathrm{Rb}$ ). Factor 3 accounts for an additional 10.5\% of the variability and has a high negative loading on thorium (Th). Overall, this solution is promising since it has summarized the seven dimensional data into three orthogonal dimensions. This is a desirable solution since it indicates that a three-way graph of factor scores might provide a convenient graphical technique for discriminating obsidian types on the basis of trace elements in the NTS area.

The factor scores which resulted from this analysis were then used to investigate the discrimination of different groups of projectile points on the basis of trace element composition. It was hoped that the use of distinctive obsidian sources might be correlated with particular temporal periods. For the purposes of this analysis, 33 projectile points were classified as Early (GBS and Pinto), Middle (Elko and Gatecliff), or Late (Rosegate and DSN). The classification results of this discriminant analysis are presented in Table 10-2. Overall, only $36.4 \%(12 / 33)$ of these points were classified correctly on the basis of the trace element data. This result is little more than that expected by chance (33\%). The Middle group exhibits the best correct classification with $62.5 \%(5 / 8)$, the Late group exhibits $40 \%$ (4/10) correct classification, and the Early group has only $20 \%(3 / 15)$ correct classification. Overall, very poor discrimination was achieved.

To a large degree, this poor classification results from obsidian which is chemically indistinguishable. Examination of 3-D scatterplots of the points on the basis of the factor 
scores suggested that only 4 chemically distinct groups exist in this sample. A $\mathrm{k}$-means cluster analysis was performed on the factor scores to yield the groups of this 4-cluster solution. This algorithm accounts for $28.5 \%$ of the variability in the factor scores. Table 10-3 presents the results of the cluster analysis in relationship to the three point groups.
Several patterns are worth noting in this analysis, but whether any of the clusters represent particular obsidian sources is uncertain. The interpretation of these data with regard to obsidian sources remains undetermined until appropriate scurcing information is acquired. However, the clusters can be assumed to at least represent geochemically distinctive ob-

TABLE 10-1. ROTATED FACTOR LOADINGS FROM PRINCIPAL COMPONENT ANALYSIS OF OBSIDIAN TRACE ELEMENT DATA FROM YUCCA MOUNTAIN PROJECTILE POINTS A.ND FLAKES.

\begin{tabular}{crrrr}
\hline Element & Factor 1 & Factor 2 & Factor 3 & Communality \\
\hline Pb & 0.3496 & 0.7998 & 0.0084 & 0.7620 \\
Th & -0.1544 & 0.1274 & -0.9813 & 0.9813 \\
Rb & -0.0302 & 0.9242 & -0.1615 & 0.8812 \\
Sr & -0.7880 & -0.4121 & 0.1567 & 0.8153 \\
Y & 0.9547 & 0.1670 & 0.1193 & 0.9535 \\
Zr & 0.9549 & -0.0552 & 0.1882 & 0.9503 \\
Nb & 0.9563 & 0.1488 & 0.1669 & 0.9645 \\
\hline
\end{tabular}

Key: $\quad$ Factor = linear combination of variables; communality = part of variance due to tactors; $\mathrm{Pb}=$ lead; $\mathrm{Th}=$ thorium; $\mathrm{Rb}=$ rubidium; $\mathrm{Sr}=$ Strontium; $\mathrm{Y}=$ yttrium; $\mathrm{Zr}=$ zirconium; $\mathrm{Nb}=$ niobium

TABLE 10-2. RESULTS OF DISCRIMINANT FUNCTION CLASSIFICATION FOR YUCCA MOUNTAIN OBSIDIAN PROJECTILE POINTS BASED ON TRACE ELEMENT FACTOR SCORES.

\begin{tabular}{ccccc}
\hline & \multicolumn{4}{c}{ Predicted Group } \\
\cline { 2 - 4 } Actual Group & Early & Middle & Late & Total \\
\hline Early & 3 & 6 & 6 & 15 \\
Middle & 2 & 5 & 1 & 8 \\
Late & 1 & 5 & 4 & 10 \\
\hline
\end{tabular}

Table 10-3. RESULTS OF CLUSTER ANALYSIS FOR THE OBSIDIAN TRACE ELEMENT DATA FROM THE YUCCA MOUNTAIN PROJECTILE POINTS.

\begin{tabular}{ccccc}
\hline & \multicolumn{3}{c}{ Point Group } & \\
\cline { 2 - 5 } Cluster & Early & Middle & Late & Total \\
\hline 1 & 6 & 6 & 5 & 17 \\
2 & 6 & 1 & 4 & 11 \\
3 & 2 & 1 & 1 & 4 \\
4 & 1 & 0 & 0 & 1 \\
\hline
\end{tabular}


sidians within this sample. In this regard it is interesting that the Early arid Late points exhibit similar proportional distributions with regard to the clusters. The Middle points, on the other hand, are concentrated within Cluster 1. The Early and Late points appear to exhibit the greatest diversity among the geochemical obsidian types represented by the clusters. These data may reflect similarities in the patterns of obsidian use by Early and Late point makers which differ from patterns of obsidian use by Middle point makers. The differences in patterns of obsidian use may be accounted for by differences in mobility or procurement mechanisms (e.g., trade).

It was hoped that this analysis might indicate differences in patterns of obsidian use for Early point makers which might account for the lack of quarrying evidence for this period in the obsidian hydration data. Instead, this analysis has suggested that Early and Late patterns of obsidian use were similar. As a result, the interpretation of early Holocene occupations remains equivocal. Alternative interpretations to early Holocene quarrying may include subsistence-based use of this place or short-term camps along watered routes of travel.

The middle Holocene evidence indicates that occupation at the obsidian nodule sources near Buckboard Mesa was rare. This apparent hiatus may reflect desertification during the middle Holocene. Previously available water and subsistence resources may have become degraded within this area or the obsidian may not have been considered useful. Middle Holocene groups may have altered their land-use patterns so that the Buckboard Mesa area was not included. The obsidian trace element data and increased occurrence of non obsidian projectile points indicate restructuring of land-use patterns at this time.

During the late Holocene, use of the Buckboard Mesa area obsidian nodules increases dramatically. This evidence implies that mobility patterns change so that utilization of the lowlands increases. In addition, technological organization and structure change with mobility alterations and the shift to bow hunting strategies. This shift makes the exploitation of small obsidian nodules so desirable that obsidian resources become exhausted. Reno and Pippin (1985:118) have noted possible evidence of prehistoric scavenging of points by DSN peoples at the Butte Wash Site. This may indicate that the intensity of obsidian nodule resource exploitation in the NTS lowlands increase significantly during the late Holocene.

Overall, there appear to be limited domestic activities at the quarry. Use of the quarry may have been embedded in seasonal subsistence activities (e.g., gathering edible seeds). Alternatively, procurement may have simply been embedded along watered routes of travel to or from uplands. For the most part, generally low artifact densities suggest diurnal or logistical use of quarries by small groups. The relationship of these activities to domestic use of the Buckboard Mesa shelters presents an interesting functional complement. However, there is also some limited evidence for occasional domestic residence at the obsidian sources themselves.

\section{Spatial Patterning}

Although spatial patterning at extensive quarries of significant sources of toolstone materials has been well documented, spatial patterning at diffuse surface scatters of small tooistone like the Buckboard Mesa area sites remains poorly studied. Spatial patterning within large quarries such as the Knife River Flint Quarries in North Dakota (Ahler and Christensen 1983; Ahler 1986), the Fort Payne Chert Quarries at Yellow Creek in Mississippi (Johnson 1981), the Tosawihi Opalite Quarries in north-central Nevada (Elston, Raven, and Budy 1987), and the Galena Chert Quarries at the Bass Site in southwestern Wisconsin (Stoltman, Behm, and Palmer 1984) illustrate similar and redundant patterning. Basically, there are two functional activity patterns within these quarries: 1) the quarry itself, where activities focus on material procurement, testing. 
and initial reduction; and 2) workshops, where the quarried materials are further reduced and prepared for transport to other locations. The quarries are strictly diurnal locations while the workshops may incorporate limited domestic activities and facilities.

Spatial evidence from the Buckboard Mesa area obsidian scatters is not easily dichotomized into quarry versus workshop areas. This blurring is probably a function of site reoccupation as well as the diffuse nature of the obsidian distribution. Concentration of quarrying activities seerns to be directly proportional to the surface concentration of toolstone. Since the obsidian nodules are small and scattered, quarrying activities are not clustered. As a result, specific quarry areas are difficult to determine as the entire obsidian nodule scatter represents a dispersed quarry. While some possible domestic camps seem to be present within the quarries, spatially segregated workshops are not evident.

The lack of spatial differentiation of activities suggests site structural patterns which are diagnostic of forager settlement organization (Binford 1987). O'Connell (1987:105) suggests that there are "relatively simple undifferentiated patterns in site structure among foragers, and more complex patterns among collectors." Spatial differentiation of activities at large quarries may reflect the more efficient use of aggregated resources by logistically organized groups. This suggests that the cost of exploiting dispersed resources among logistically organized groups is prohibitive. Exploitation of dispersed lithic resources may be more efficiently pursued by foragers that "map onto" resources (Binford 1980:5-10). As a result, quarry patterns may differ due to both the dispersed distribution of toolstone and its more efficient utilization by groups that do not produce spatial patterns with well-defined activity differentiation.

The scale of activity differentiation within the dispersed obsidian nodule quarries probably relates most directly to flake scatter pat- terns on the order of a few meters in diameter (e.g.. Newcomer and Sieveking 1980) and small foraging group residential patterns on the order of 40 square meters in area (Yellen 1977; Weissner 1974; Hayden 1979). Binford $(1983: 144-192,1987)$ shows that the scale of spatial patterns at the activity level is usually on the order of a few square meters. O'Connell $(1987: 103-104)$ has suggested that the determinants of site structure are primarily related to 1) subsistence organization, 2) seasonal variation, 3) length of occupation, and 4) group size. He further demonstrates that large exposures are necessary to evaluate site structure and that small artifacts may be the inost useful behavioral indicators.

These observations are relevant to evaluating the relationship of the scale of spatial patterning versus the scale of data recovery. Although occupation at the scatters may involve thousands of square meters, the scale of activity patterning is on the order of a few square meters. These facts are directly relevant to interpreting the meaning of spatial patterning evident at the scatters and suggest that 10-by-10 m grid units may not provide the degree of resolution required to address site spatial investigations within the quarry. Inaccuracy is compounded by the arbitrary imposition of coarse grained collection grids on fine grained spatial patterning. For example, a grid unit that bisects an artifact cluster appears half as dense as one that encompasses a cluster.

So what do the 10-by-10 m grid units identify at the Buckboard Mesa obsidian scatters? The ethnoarchaeological data discussed above and archaeological studies by Ebert (1986) and Seaman, Doleman, and Chapman (1988) suggest that $10-b y-10$ m grid units may identify high density clusters on like large sites or residential areas. Matching the grid size with the grain of the behavioral pattern is essential. The interpretation of $10-$ by $-10 \mathrm{~m}$ grid units at the obsidian scatters is problematic since activities like obsidian procurement, testing, and initial reduction probably occurred 
within a few square meters. If site structural information is the goal of data recovery within similar quarries, then finer grained resolution is required in data recovery.

\section{Temporal Patterning}

Studies of large aggregated resource quarries also show evidence of significant temporal patterning. The Knife River Flint Quarries (Ahler and Van Nest 1985) and the Yellow Creek Quarries (Johnson 1981) both exhibit greater spatial differentiation of activios through time. This change is most likely the result of systemic change among the groups exploiting the resources. Evidence for temporal change in patterns of exp'oitation at the Buckboard Mesa obsidian scatters is limited. The palimpsest nature of these deposits limits the ability to discern temporal patterning if it exists. The only clear temporal patterning evident at the obsidian scatters is an increasing intensity in utilization over the past 3000 years.

Wiant and Hassen (1985:104) note that "temporal availability of biotic resources and resource procurement scheduling are principal components for organizing technology." Scheduling pressures limit the accessibility of lithic resources, but accessibility may be increased by relaxation in scheduling constraints as a result of resource changes or settlement-sutisistence changes. Henry (1989:139-140) has stated that " the specific patterns that reduction sequences assume are most strongly influenced by the variables of (1) distribution of raw material, water, and food sources; (2) site permanence; and (3) settlement permanence." In addition, Johnson (1989:121-122) has suggested that the factors responsible for differences in biface production strategies are resource availability (and access) and settlement strategy. He also suggests that differences in production trajectories can be measured by trajectory length which varies as a function of site type and distance to source.
Another point of technological interest at the obsidian scatters is related to current arguments about the role of core versus biface technology with regard to group mobility (e.g.. Johnson 1985, 1986, 1987; Parry and Kelly 1987; Kelly 1988). In simplistic terms, the high ratio of cores to bifaces at $26 \mathrm{Ny} 4892$ suggests an emphasis on core reduction at the expense of biface production. This pattern may contradict expected associations of high mobility and biface-oriented technology in the context of prehistoric foraging economies in southern Nevada (e.g., Parry and Kelly 1987; Kelly 1988). In particular, the lack of evidence for transported bifaces and utilized BTFs at $26 \mathrm{Ny} 4892$ is unexpected under this model. There are some late stage, vein opal, and chert/chalcedony bifaces discarded at $26 \mathrm{Ny} 4892$, but they are generally too small for use as bifacial cores. In addition, there are no vein opal or chert/chalcedony BTFs at 26Ny4892. These patterns seem to suggest that bifaces did not serve as cores very often but that the bifaces were transported and used as tools. The high proportion of cores at 26 Ny4892 may be $a$ function of limited toolstone size rather than of mobility parameters (cf. Johnson 1987; Keily and Parry 1987; Patterson 1987). The evidence for transported bifacial cores within the lithic industries of southern Nevada needs further attention. The high mobility patterns of these Mojave Desert foragers should conform to the transported bifacial core model. If there is no support for this association in southern Nevada, then additional complexity may be required in this equation.

Finally, evidence of scavenging behavior at 26Ny4892 is significant since this strategy is unexpected at quarries. For example, Schiffer has suggested just the opposite strategy regarding recycling at lithic quarries.

A counterpoint to the space station (which leaves no recognizable archaeological record) is furnished by lithic 
quarry-workshops, where the proportion of reuse and depositional processes is reversed. During the course of these normal activities, a great many flakes, judged by the knapper to be unsuitable for further modification, are discarded along with countless cortical flakes, odd chunks, tiny flakes and shatter, and microflakes. Scarcely any reuse can be discerned in a lithic quarry-workshop; as a result, the archaeological record contains the bountiful traces of virtually every knapping act that took place. (Schiffer 1987:27-28)

The evidence from $26 \mathrm{Ny} 4892$ demonstrates that this position is untenable. In fact, the recurrent reuse of the obsidian nodule scatters may even be argued to encourage recycling behavior. The overexploitation and exhaustion of the obsidian nodules may have accelerated scavenging. In addition, there may have been other processes acting upon the cultural systems involved which led to increased recycling behavior. In any case, it seems likely that recycling behavior at $26 \mathrm{Ny} 4892$ is largely a function of the intensity of resource exploitation and immediate situational needs for lithic materials.

Kelly (1988:726-727) has suggested that the context of recycling behavior in the Carson Sink area changes through time and is related to more residential use of the valley floor during the Reveille phase (EIko) about 3000 years ago. Since toolstone sources are scarce on the Carson Sink valley floor, raw material scavenging occurs when groups shift to mobility systems with residential use of the valley floor. Kelly (1988:731) also suggests that a technological shift to nonresharpenable points reflects changes toward planned hunting strategies at this time in the Carson Sink. Regional variation in this pattern and timing changes should be explored. Thomas (1988:394-414), for example, does not find similar diachronic patterns in the Monitor Valley area. The degree to which these regional patterns are evident in the southern Nevada area needs to be explored.

\section{Technological Analysis}

In conclusion, the strategy of technological analysis in future NTS research is worth consideration. Johnson (1987:11) suggests that the following variables are necessary to explain tool production systems: 1) raw material availability, 2) trajectory flexibility, 3) mobility, 4) subsistence diversity, 5) intended function, and 6) social organization. Most of these variables were employed ir, the interpretations derived from this analysis but which explanation is best remains undetermined. While these variables may be helpful to technological analysis, they do not serve as explanations in themselves. Linkage of these variables to appropriate explanatory frameworks is currently incomplete.

Odell (1989) points out the need for development and use of appropriate techniques to address the diversity of research questions that may be posed by lithic analysis. However, determining which analytical techniques are appropriate under this suggestion becomes a matter of theoretical argument. Odell (1989) begins with a behavioral pattern, then adduces several possible measures of this pattern. Each measure is then compared to the expected results. If the result is different than expected, then the behavioral pattern is rejected. in other words, Odell (1989) appears to suggest that when the data meet our expectations, we have confirmed our analytical technique. Of course, this method is wholly dependent upon the correct adducement of the analytical signature of particular behaviors. Two important issues must be considered in technological analysis: 1) how are appropriate analytical techniques designed and interpreted, and 2) how do we decide when these behavioral measures are valid? The validity of the relationship of analytical techniques to behavioral measures is determined by argument from empiri- 
cal references. While the archaeological record may provide some of these references, many must be independent of the archaeological record. In particular, experimental work and toolstone source studies are essential and integral to informed lithic interpretations. Future archaeological research in the NTS region must incorporate these strategies as integrated parts of artifact analysis. 


\section{MANAGEMENT RECOMMENDATIONS}

Site $26 \mathrm{Ny} 4894$ and a large portion of Site 26 Ny4982 have been collected and tested for subsurface cultural deposits. No significant archaeological resources remain in these areas, so additional grounc. disturbing activities in the regions of complete : ollection will not have adverse impacts to cultural resources. There is, however, a large portion of $26 \mathrm{Ny} 4892$ which has not been collected and which contains cultural resources. Since this area has not been surveyed, the nature of the resources in the uncollected portions of $26 \mathrm{Ny} 4892$ is unknown. We recommend, therefore, that prior to ground disturbing activities in this area, an archaeological reconnaissance be conducted. If the cultural materials observed during these surveys consist of quarrying debris similar to that collected, we would consider this type of activity to be well represented in this locality and would not recommend additional data recovery. If, however, the cultural resources observed appear to indicate prehistoric activities other than quarrying, additional data recovery at these localities may be warranted.
The majority of the rockshelters and rock art sites along the rim of Buckboard Mesa are of National Register-quality and should be avoided. Access and vehicle traffic have increased considerably since the completion of the road. However, since there is no reason to stop in this area, there does not appear to be a significant danger of indirect impacts to these sites from unauthorized collectors. On the other hand, if facilities are developed in this area, specifically a "batch plant" or the like, then the probability of indirect impacts is significantly increased. Addressing these types of impacts is difficult and is a Test Site-wide problem. Since these sites are, for the most part, remote and unguarded, keep-out fences and/or signing is not likely to be an effective deterrent and may actually attract collectors to the sites. We believe that the most effective approach to dealing with unauthorized collection is to educate employees of the Test Site to the fact that it is improper, and usually illegal, to collect artifacts from federally administered lands without proper authorization. This education could be imparted to employees in the introductory briefing, similar to the warnings now included in the briefings about disturbing wildlife. 


\section{REFERENCES}

Addington, L.R.

1986 Lithic Illustration. University of Chicago Press, Chicago.

Ahler, S.A.

1986 The Knife River Flint Quarries: Excavations at Site 32DU508. State Historical Society of North Dakota, Bismark.

1989a Experimental Knapping with KRF and Midcoritinental Cherts: Overview and Applications. In Experiments in Lithic Technology, edited by D.S. Amick and R.P. Mauldin, pp. 199-234. International Series 528. British Archaeological Reports, Oxford.

1989b Mass Analysis of Flaking Debris: Studying the Forest Rather than the Trees. In Atternative Approaches to Lithic Analysis, edited by D. Henry and G. Odell, pp. 85-118. Archaeologıcal Papers of the American Anthropological Association No. 1. Washington.

Ahler, S.A., and R.C. Christensen

1983 A Pilot Study of Knife River Flint Procurement and Reduction at Site 32DU508, A Quarry and Workshop Location in Dunn County, North Dakota. Contribution No. 186. Department of Anthropology and Archaeology, University of North Dakota, Grand Forks.

Ahler, S.A., and J. Van Nest

1985 Temporal Change in Knife River Flint Reduction Strategies. In Lithic Resource Procurement: Proceedings from the Second Conference on Prehistoric Chert Exploitation, ecited by S.C. Vehik, pp. 183-198. Occasional Paper No. 4. Center for Archaeological Investigations, Southern Illinois University, Carbondale.

Ambrose, W.

1976 Intrinsic Hydration Rate Dating of Obsidian. In Advances in Obsidian Glass Studies: Archaeological and Geochemical Perspectives, edited by R.E. Taylor, pp. 81-105. Noyes Press, Park Ridge, New Jersey.

Amick, D.S.

1985 Late Archaic Fort Payne Biface Manufacture at the Topsy Site (40WY204), Buffalo River Basin, Tennessee. Southeastern Archaeology 4(2):134-151.

1987a Calculating Artifact Planview Area. Lithic Technology 15(3):90-95.

1987b La Jara Mesa Lithic Scatters and East Grants Ridge Obsidian Exploitation: Turkey Farm Project, Grants District. Report prepared for the U.S.D.A. Forest Service, Cibola National Forest, Albuquerque.

Amick, D.S., R.P. Mauldin, and L.R. Binford

1989 The Potential of Experiments in Lithic Technology. In Experiments in Lithic Technology, edited by D.S. Amick and R.P. Mauldin, Pp. 1-14. International Series 528. British Archaeological Reports, Oxford.

Amick, D.S., R.P. Mauldin, and S.A. Tomka

1988 An Evaluation of Debitage Produced by Experimental Bifacial Core Reduction of a Georgetown Chert Nodule. Lithic Technology 17(1):26-36. 
Amsden, C.A.

1935 The Pinto Basin Artifacts. In The Pinto Basin Site, edited by E.W.C. Campbell and W.H. Campbell, pp. 33-51. Southwest Museum Papers 9, Los Angeles.

Archaeological Researches in Nevada. In Indian Notes, April, 1925.

Baker, C.M.

1978 The Size Effect: An Explanation of Surface Artifact Content. American Antiquity 43(2):288-293.

Baumhoff, M.A., and J.S. Byrne

1959 Desert Side-Notched Points as a Time Marker in California. University of California Archaeological Survey Reports 48(7):32-65.

Beatley, J.C.

1976 Vascular Plants of the Nevada Test Site and Central-Southern Nevada: Ecologic and Geographic Distributions. U.S. Energy Research and Development Administration, Technical Information Center, Springfield.

The Beatty Bullfrog Miner, September 16, 1905.

Beck, C.

1988 Diffusion and Great Basin Chronology. Paper presented at the 21st Biennial Great Basin Anthropological Conference, Park City, Utah.

Bedwell, S.F.

1970 Prehistory and Environment of the Pluvial Fort Rock Lake Area of South Central Oregon.

Ph.D. dissertation, Department of Anthropology, University of Oregon, Eugene.

1973 Fort Rock Basin: Prehistory and Environment. University of Oregon Books, Eugene. Bergin, K.A., C.S. Crownover, C. Stevens, R. Stockton, S. Vaughan, D. Jenkins, R. Brooks, D. Ferraro, A. Turner, L. Kirkberg, P. Olson, R. Maus, G. Stough, R. Scheuch, and G. Tullis

1979 Final Report on the 1978 Archaeological Investigations of the Nellis Air Force Bombing and Gunnery Ranges, Nye, Lincoln and Clark Counties, Nevada. Archaeological Research Center, Museum of Natural History, University of Nevada, Las Vegas.

Berry, M.S.

1974 The Evans Mound: Cultural Adaptation Southwestern Utah. Unpublished Master's thesis, Department of Anthropology, University of Utah, Salt Lake City.

Bettinger, R.L., and M.A. Baumhoff

1983 Return Rates and Intensity of Resource Use in Numic and Pre-Numic Adaptive Strategies. American Antiquity 48(4):830-884.

Binford, L.R.

1979 Organization and Formation Processes: Looking at Curated Technologies. Journal of Anthropological Research 35(3):255-273.

1980 Willow Smoke and Dog's Tails: Hunter-Gatherer Settlement Systems and Archaeological Site Formation. American Antiquiry 45(1):4-20.

Binford, L.R.

1983 In Pursuit of the Past. Thames and Hudson, New York. 
1987 Researching Ambiguity: Frames of Reference and Site Structure. In Method and Theory for Activity Area Research: An Ethnoarchaeological Approach, edited by S. Kent, pp. 449-512. Columbia University Press, New York.

Binford, L.R., and G.I. Quimby

1963 Indian Sites and Chipped Stone Materials in the Northern Lake Michigan Area. Fieldiana Anthropology 36(12):277-307.

Boksenbaum, $M$.

1980 Basic Mesoamerican Stone Working: Nodule Bashing? Lithic Technology 9(1):12-26.

Bowman, H.R., F. Asaro, and I. Perlman

1973 Composition Variations in Obsidian Sources and the Archaeological Implications. Archaeometry 15(1):123-127.

Bryan, A.L.

1979 Smith Creek Cave. In The Archaeology of Smith Creek Canyon, Eastern Nevada, edited by D.R. Tuohy and D.L. Rendall, pp. 163-253. Anthropological Papers 17. Nevada State Museum, Carson City.

Byers, F.M. Jr., and D. Cummings

1967 Geologic Map of the Scrugham Peak Quadrangle, Nye County, Nevada $(1: 24,000)$. Map GQ-695. U.S. Geological Survey, Washington.

Byers, F.M. Jr., C.L. Rogers, W.J. Carr, and S.J. Luft

1966 Geologic Map of the Buckboard Mesa Quadrangle, Nye County, Nevada $(1: 24,000)$. Map GQ-552. U.S. Geological Survey, Washington.

Byers, F. M. Jr., W. J. Carr, R. L. Christiansen, P. W. Lipman, Paul P. Orkild, and W.D. and W.D. Quinlivan

1976 Geological Map of the Timber Mountain Caldera Area, Nye County, Nevada. Map 1-891. Miscellaneous Investigation Series. U.S. Geological Survey, Washington, D.C.

Callahan, E.

1979 The Basics of Biface Knapping in the Eastern Fluted Point Tradition: A Manual for Flintknappers and Lithic Analysts. Archaeology of Eastern North America, 7(1):1-180.

Camilli, E.L.

1983 Site Occupational History and Lithic Assemblage Structure: An Example from Southeastern Utah. Ph.D. dissertation, Department of Anthropology, University of New Mexico, Albuquerque. University Microfilms, Ann Arbor.

Chapman, R.H.

1907 The Deserts of Nevada and Death Valley. Scientific American, Supplement No. 1631, April 6, pp. 26126-26129.

Chapman, J.

1975 The Rose Island Site and the Bifurcate Point Tradition. Report of Investigations No. 14. Department of Anthropology, University of Tennessee, Knoxville.

Clark, D.W.

1984 Some Practical Applications of Obsidian Dating in the Subarctic. Arctic 37(2):91-109. 
Code of Federal Regulations (CFR)

1987 National Register of Historic Places (36 CFR 60).

Coombs, G.B., R.H. Crabtree, and E. Warren

1979 The Archaeology of the Northeast Mojave Desert. U.S. Department of Interior, Bureau of Land Management, California, Cultural Resources Publications.

Cornwall, H.R.

1972 Geology and Mineral Deposits of Southern Nye County, Nevada. Bulletin 77. Nevada Bureau of Mines and Geology, Mackay School of Mines, University of Nevada, Reno.

Crabtree, D.E.

1970 Flaking Stone with Wooden Implements. Science 169:146-153.

1972 An Introduction to Flintworking. Occasional Paper 28. Idaho State University Museum, Pocatello.

d'Azevedo, W.L. (editor)

1986 Great Basin. Handbook of North American Indians, vol. 11, William G. Sturtevant, general editor. Smithsonian Institution, Washington, D.C.

Davis, E.L.

1978 The Ancient Californians: Rancholabrean Hunters of the Mojave Lakes County. Science Series 29. Natural History Museum of Los Angeles County, Los Angeles.

Davis, J.O.

1983 Geological Reconnaissance and Chronologic Studies. Desert Research Institute Social Sciences Center Technical Report No. 33, Reno.

Donnan, C.B.

1964 A Suggested Cultural Sequence for the Providence Mountains (Eastern Mojave Desert). Annual Reports of the University of California Archaeological Survey for 1963-1964:1-23.

Ebert, J.I.

1986 Distributional Archaeology: Nonsite Discovery, Recording and Analytical Methods for Application to the Surface Archaeological Record. Ph.D. dissertation, Department of Anthropology, University of New Mexico, Albuquerque. University Microfilms, Ann Arbor.

Elston, R.G.

1982 Good Times, Hard Times: Prehistoric Culture Change in the Western Great Basin. In Man and Environment in the Great Basin, edited by D.B. Madsen and J.F. O'Connell, Pp. 186-206. Society for American Archaeology Paper 2, Washington,D.C.

Elston, R.G.

1986 Prehistory of the Western Area. In Great Basin, edited by Warren L. d'Azevedo, pp. 135-148. Handbook of North American Indians, vol. 11, William G. Sturtevant, general editor. Smithsonian Institution, Washington, D.C. 
Elston, R.G., C. Raven, and E.E. Budy

1987 An Intensive Reconnaissance of the Tosawihi Quarries Archaeological District (Site 26Ek3032). Intermountain Research Project No. 611. Bureau of Land Management Cultural Resources Report No. 1-1101(P). Report prepared for Touchstone Resources Company, Battle Mountain, Nevada.

Elston, R.G., and C.D. Zeier

1984 The Sugarloaf Obsidian Quarry. NWC Administration Publication 313. Technical Information Department, Naval Weapons Center, China Lake, California.

Ericson, J.E., J.D. Mackenzie, and R. Berger

1976 Physics and Chemistry of the Hydration Process in Obsidians I: Theoretical Implications. In Advances in Obsidian Glass Studies: Archaeological and Geochemical Perspectives, edited by R.E. Taylor, Pp. 25-45. Noyes Press, Park Ridge, New Jersey.

Fowler, C.S.

1972 Some Ecological Clues to Proto-Numic Homelands. In Great Basin Cultural Ecology: A Symposium, edited by D.D. Fowler, pp. 105-121. Desert Research Institute Publications in the Social Sciences 8, Reno.

Fowler, D.D., and D.B. Madsen

1986 Prehistory of the Southeastern Area. In Great Basin, edited by W.L. d'Azevedo, pp. 173-182. Handbook of North American Indians, vol. 11, William G. Sturtevant, general editor. Smithsonian Institution, Washington, D.C.

Friedman, I.

1968 Hydration Rind Dates Rhyolite Flows. Science 159:878-880.

Friedman, I., and R.L. Smith

1960 A New Dating Method Using Obsidian: Part I, the Development of the Method. American Antiquity 25(4):476-522

Goren-Inbar, N.

1988 Too Small to be True? Reevaluation of Cores on Flakes in Levantine Mousterian Assemblages. Lithic Technology 17(1):37-44.

Gramly, R.M.

1980 Raw Material Source Areas and "Curated" Tool Assemblages. American Antiquity 45(4):823-833.

Harrington, M.R.

1925 Unpublished Letter Dated May 7, 1925, to Governor J.G. Scrugham. File 44012, Nevada Historical Society, Reno.

Harrington, M.R.

1927 Some Lake-Bed Camp-Sites in Nevada. Museum of the American Indian, Heye Foundation Indian Notes 4(1):40-47, New York.

1957 A Pinto Site at Little Lake, California. Southwest Museum Papers 17. Los Angeles.

Harris, R.P.

1973 Nevada Postal History 1861 to 1972. Bonanza Press, Santa Cruz, California. 
Hayden, B.

1979 Paleolithic Reflections: Lithic Technology and Ethnographic Excavations Among Australian Aborigines. Humanities Press, Garden City, New Jersey.

1980 Confusion in the Bipolar World: Bashed Pebbles and Splintered Pieces. Lithic Technology $9(1): 2-7$.

Heizer, R.F., and A.E. Treganza

1944 Mines and Quarries of the Indians of California. California Journal of Mines and Geology 40:291-359.

Henry, D.O.

1989 Correlations Between Reduction Strategies and Settlement Patterns. In Alternative Approaches to Lithic Analysis, edited by D. Henry and G. Odell, pp. 139-155. Archeological Papers of the American Anthropological Association No. 1. Washington.

Henry, D.O., C.V. Haynes, and B. Bradley

1976 Quantitative Variations in Flaked Stone Debitage. Plains Anthropologist 21(71):57-61.

Henton, G.H.

1986a A Class III Cultural Resources Reconnaissance of the New Right-of-Way for the Buckboard Mesa Road, Phase 1, Station $2+00$ to Station $158+\infty 0$, Nye County, Nevada. Desert Research Institute Cultural Resources Reconnaissance Short Report No. SR061786-1.

1986b A Class III Cultural Resources Reconnaissance of the New Right-of-Way for the Buckboard Mesa Road, Phase 2, Station $158+00$ to Station $805+58$, Nye County, Nevada. Desert Research Institute Cultural Resources Reconnaissance Short Report No. SR061886-1.

Henton, G.H., and S.R. Durand

1989 Projectile Point Measurement and Classification Using Digital Image Processing. Ms. on file. Quaternary Sciences Center, Desert Research Institute, Reno.

Henton, G.H., and L.C. Pippin

1987 Data Recovery Plan for Negating Potential Adverse Effect on Cultural Resources Along Phase 2 of the Buckboard Mesa Road Improvement, Nye County, Nevada. Ms. on file at the Desert Research Institute Social Sciences Center, Reno. (March)

1988 Prehistoric and Historic Archaeology of Fortymile Canyon, Yucca Wash, and Midway Valley Near Yucca Mountain, Nye County, Southern Nevada. Desert Research Institute Quaternary Sciences Center Technical Report 60. Reno.

1989 Archaeological Data Recovery at Drill Pad U19au, Nye County, Nevada. Desert Research Institute Quaternary Sciences Center Technical Report 55. Reno (Review Draft).

Hester, T.R.

1973 Chronological Ordering of Great Basin Prehistory. Contributions of the University of California Archaeological Research Facility 17:55-128. 
Hinrichs, E.N., R.D. Krushensky, and S.J. Luft

1967 Geologic Map of the Ammonia Tanks Quadrangle, Nye County, Nevada. U.S. Geological Survey, Washington, D.C.

Hoffman, C.M.

1985 Projectile Point Maintenance and Typology: Assessment with Factor Analysis and Canonical Correlation. In For Concordance in Archaeological Theory, edited by C. Carr. pp. 566-612. Westport Publishers, Kansas City, Missouri.

Holmer, R.N.

1986 Common Projectile Points of the Intermountain West. In Anthropology of the Desert West: Essays in Honor of Jesse D. Jennings, edited by C.J. Condie and D.D. Fowler, pp. 89-115. Anthropological Papers No. 110. University of Utah, Salt Lake City.

Honea, $\mathrm{K}$.

1965 The Bipolar Flaking Technique in Texas and New Mexico. Bulletin of the Texas Archaeological Society 36:259-267.

Hughes, R.E.

1988 The Coso Volcanic Field Reexamined: Implications for Obsidian Sourcing and Hydration Dating. Geoarchaeology 3(4):253-265.

Hughes, R.E., and J.A. Bennyhoff

1986 Early Trade. In Great Basin, edited by W.L. d'Azevedo, pp. 238-255. Handbook of North American Indians, vol. 11, William G. Sturtevant, general editor. Smithsonian Institution, Washington, D.C.

Ingbar, E.E.

1989 The Hanson Site and Folsom on the Northwestern Plains. In Ice-Age Hunters of the Rockies, edited by D.J. Stanford and J.S. Day, in press. Denver Museum of Natural History.

Jackson, R.J.

1984 Current Problems in Obsidian Hydration Analysis. In Obsidian Studies in the Great Basin, edited by R.E. Hughes, pp. 103-115. Contributions of the University of California Archeological Research Facility 45.

Jackson, R.J.

1985 Obsidian Hydration Analysis. In The Archaeology of Hidden Cave, Nevada, edited by D.H. Thomas, pp. 354-357. Anthropological Papers 61(1). American Museum of Natural History. New York.

James, S.R.

1986 What Mean These Sherds? A Functional Approach to Fremont Ceramics in the Western Periphery. In Pottery of the Great Basin and Adjacent Areas, edited by S. Griset, pp. 107-118. Anthropological Papers 111. University of Utah, Salt Lake City. 
Jenkins, D.L., C.N. Warren, and T. Wheeler

1984 Test Excavation and Data Recovery at the AwI Site, SBr4562: A Pinto Site at Fort Irwin. San Bernardino County, California. Fort Inwin Archaeological Project Res sarch Report. Prepared for Interagancy Archaeological Services, National Park Service, Western Region, San Francisco.

Jennings, J.D.

1986 Prehistory: Introduction. In Great Basin, edited by W.L. D'Azevedo, pp. 113-119. Handbook of North American Indians, vol. 11, William G. Sturtevant, general editor. Smithsonian Institution, Washington, D.C.

Johnson, J.K.

1981 Lithic Procurement and Utilization Trajectories: Analysis, Yellow Creek Nuclear Power Plant Site, Tishomingo County, Mississippi, Archaeological Papers of the Center for Archaeological Research No. 1, vol. 2. Tennessee Valley Authority Publications in Anthropology No. 28. University of Mississippi.

1985 Patterns of Prehistoric Chert Procurement in Colbert Ferry Park, Northwest Alabama. In Lithic Resource Procurement: Proceedings from the Second Conference on Prehistoric Chert Exploitation, edited by S.C. Vehik, pp. 153-164. Occasional Paper No. 4. Center for Archaeological Investigation:, Southern Illinois University, Carbondale.

1986 Amorphous Crine Technologies in the Midsouth. Midcontinental Journal of Archaeology $11(2): 135-151$.

1987 Introduction. In The Organization of Core Technology, edited by J.K. Johnson and C.A. Morrow, pp. 1-12. Westview Press, Boulder, Colorado.

1989 The Utility of Production Modeling as a Framework for Regional Analysis. In Alternative Approaches to Lithic Analysis, edited by D.O. Henry and G.H. Odell, pp. 119-138. Archeological Papers of the American Anthropological Association No. 1. Washington.

Jones, G.T.

1984 Prehistoric Land Use in the Steens Mountain Area, Southeastern Oregon. Ph.D. dissertation, Department of Anthropology, University of Washington, Seattle. University Microfilms, Ann Arbor.

Kelly, R.L.

1988 The Three Sides of a Biface. American Antiquity 53(4):717-734.

Kobayashi, $\mathrm{H}$.

1975 The Experimental Study of Bipolar Flakes. In Lithic Technology: Making and Using Stone Tools, edited by E.H. Swanson, pp. 115-128. Mouton, The Hague.

Koenig, G.

1984 Beyond This Place, There will be Dragons. The Routes of the Tragic Trek of the Death Valley 1849 ers through Nevada, Death Valley, and to Southern California. Arthur $\mathrm{H}$. Clark, Glendale, California.

Koopmans, L.H.

1987 Introduction to Contemporary Statistical Methods. 2d ed. Duxbury Press, Boston. 
Kowta, M.

1969 The Sayles Complex: A Late Milling Stone Assemblage from Cajon Pass and the Ecological Implications of its Scraper Planes. Publications in Anthropology 6. University of California, Berkeley.

Kuhn, S.L.

1989 Hunter-Gatherer Foraging Organization and Strategies of Artifact Replacement and Discard. In Experiments in Lithic Technology, edited by D.S. Amick and R.P. Mauldin, pp. 33-48. International Series 528. British Archaeological Reports, Oxford.

Lamb, S.M.

1958 Linguistic Prehistory in the Great Basin. International Journal of American Linguistics 24(2):95-100.

Lanning, E.P.

1963 Archaeology of the Rose Spring Site, INY-372. University of California Publications in American Archaeology and Ethnology 49(3):237-336.

Larson, D.O.

1981 A Study of the Settlement Patterns of Southern Nevada as Reflected by the Archaeological Records. Western Anasazi Reports 3(1). Cedar City, Utah.

Leaf, G.D.

1979 Variation in Form of Bipolar Cores. Plains Anthropologist 24(83):39-50.

Leonard, N.N., III., and C.E. Drover

1980 Prehistoric Turquoise Mining in the Halloran Springs District, San Bernardino County, California. Journal of California and Great Basin Anthropology 2(2):245-256.

Liverman, J.L.

1977 Final Environmental Impact Statement, Nevada Test Site, Nye County, Novada. U.S. Energy Research and Development Administration, Technical Information Center, Springfield.

Lockett, C.L.

1988 Laboratory Methods and Procedures. In Prehistoric and Historic Archaeology of Fortymile Canyon, Yucca Wash, and Midway Valley Near Yucca Mountain, Nye County, Southern Nevada, by G.H. Henton and L.C. Pippin, pp.39-61. Desert Research Institute Quaternary Sciences Center Technical Report No. 60, Reno.

Long. $M$.

1950 The Shadow of the Arrow. Caxton Printers, Caldwell, Idaho.

Lyneis, M.M.

1982a An Archaeological Element for the Nevada Historic Preservation Plan. Nevada Division of Historic Preservation and Archaeology, Carson City.

1982b Prehistory in the Southern Great Basin. In Man and Environment in the Great Basin, edited by D.B. Madsen and J.F. O' Connell, pp. 172-185. Society for American Archaeology Papers 2, Washington, D.C. 
Lyneis, M.M., J. Clark, R. McCarty, and T. Shepperson

1978 Archaeological Element, Historic Preservation Assessment and Planning Process, City of Las Vegas. Prepared for the City of Las Vegas.

Madsen, D.B.

1975 Dating Paiute-Shoshone Expansion in the Great Basin. American Antiquity 40(1):82-85.

1986 Prehistoric Ceramics. In Great Basin, edited by W.L. d'Azevedo, pp. 206-214. Handbook of North American Indians, vol. 11, William G. Sturtevant, general editor. Smithsonian Institution, Washington, D.C.

Magne, M.P.R.

1985 Lithics and Livelihood: Stone Tool Technologies of Central and Southern Interior British Columbia. Mercury Series. Archaeological Survey of Canada Paper No. 133. National Museum of Man, Ottawa.

Marvin, R.F., F. M. Byers, Jr., H.H. Mehnert, P.P. Orkild, and T.W. Stern

1970 Radiometric Ages and Stratigraphic Sequence of Volcanic and Plutonic Rocks, Southern Nye and Western Lincoin Counties, Nevada. Geological Society of America Bulletin 81:2557-2676.

Mauldin, R.P., and D.S. Amick

1989 Investigating Patterning in Debitage from Experimental Bifacial Core Reduction. In Experiments in Lithic Technology, edited by D.S. Amick and R.P. Mauldin, pp. 67-88. International Series 528. British Archaeological Reports, Oxford.

McFadden, L.D., S.G. Wells, and M.J. Jercinovic

1987 Influences of Eolian and Pedogenic Processes on the Evolution and Origin of Desert Pavements. Geology 15:504-508.

McHugh, W.P. and B.A. Mitchum

1981 Comments on "Quantitative Characieristics of Debitage from Heat Treated Chert" by L.W. Patterson. Plains Anthropologist 25:327-332.

McGuire, K.R., A.P. Garfinkel, and M.E. Basgall

1981 Archaeological Investigations in the El Paso Mountain of the Western Mojave Desert: The Bickel and Last Chance Sites (CA-Ker-250 and 261). Report prepared by Far West Anthropological Research Group, Inc. for U.S. Bureau of Land Management, Riverside, California.

Mclane, A.R.

1988 S.M. Wheeler, Nevada Test Site's First Archaeologist. Paper presented at the 21st Biennial Great Basin Anthropological Conference, Park City, Utah, October, 1988.

Meighan, C.W.

1981 The Little Lake Site, Pinto Points, and Obsidian Dating in the Great Basin. Journal of California and Great Basin Anthropology 3(2):200-214.

Meighan, C.W. and C.V. Haynes

1970 The Borax Site Revisited. Science 167:1213-1221. 
Michels, J.W.

1965 Lithic Seria Chronology Through Obsidian Hydration Dating. Unpublished Ph.D. dissertation, University of California, Los Angeles.

1973 Dating Methods in Archaeology. Seminar Press, NY.

Michels, J.W., and I.S.T. Tsong

1980 Obsidian Hydration Dating: A Coming of Age. In Advances in Archaeological Method and Theory, vol. 3, edited by M.B. Schiffer, pp. 405-444. Academic Press, New York.

The Mining Press, March, 1940.

Morrissey, F.R.

1968 Turquoise Deposits of Nevada. Report 17. Nevada Bureau of Mines and Geology, Mackay School of PAines, University of Nevada, Reno.

Newcomer, M.H., and F. Hivernell-Guerre

1974 Nucleus Sur Eclat: Technologie et Utilisation pa: Differentes Cultures Prehistoriques. Bulletin de la Societe Prehistorique Francaise 71:119-128.

Newcomer, M.H., and G. de G. Sie reking

19.80 Experimental Flake Scatter Patterns: A New Interpretative Technique. Journal of Field Archaeology 7(3):345-352.

NTS News, September 14, 1962.

O'Connell, J.F.

1967 Elko Eared/Elko Corner-Notched Projectile Points as Time Markers in the Great Basin. University of California Archaeological Survey Reports 71:129-140.

1987 Alyawara Site Structure and Its Archaeological Implications. American Antiquity 52(1):74-108.

Odell, G.H.

1989 Fitting Analytical Techniques to Prehistoric Problems with Lithic Data. In Alternative Approaches to Lithic Analysis, edited by D.O. Henry and G.H. Odell, pp. 159-182. Archaeological Papers of the American Anthropological Association No. 1. Washington, D.C.

Parry, W.J., and R.L. Kelly

1987 Expedient Core Technology and Sedentism. In The Organization of Core Technology, edited by J.K. Johnson and C.A. Morrow, pp. 285-304. Westview Press, Boulder, Colorado.

Patterson, L.W.

1987 Amorphous Cores and Utilized Flakes: A Commentary. Lithic Technology $16(2-3): 51-53$.

Pippin, L.C.

1984 Limited Test Lxcavations at Selected Archaeological Sites in the NNWSI Yucca Mountain Project Area, Southern Nye County, Nevada. Desert Research Institute Social Sciences Ter hnical Report 40, Reno. 
Pippin, L.C.

1986 An Overview of Cultural Resources on Pahute and Rainier Mesas on the Nevada Test Site, Nye County, Nevada. Desert Research Institute, Social Sciences Center Technical Report 45.

Pippin, L.C., R.L. Clerico, and R.L. Reno

1982 An Archaeological Reconnaissance of the NNWS/ Yucca Mountain Project Area, Southern Nye County, Nevada. Desert Research Insítute Social Sciences Center Publication 28, Reno.

Pippin, L.C., and J.O. Davis

1988 The Project Area. In Prehistoric and Historic Archaeology of Fortymile Canyon, Yucca Wash, and Midway Valley near Yucca Mountain, Nye County, Southern Nevada, by G.H. Henton and L.C. Pippin, pp. 7-16. Desert Research Institute Quaternary Sciences Center Technical Report No. 60, Reno.

Pippin, L.C., and G.H. Henton

1988 Long Range Study Plan for Negating Potential Adverse Affects to Cultural Resources on Pahute and Rainier Mesas, Nevada Test Site, Nevada. Ms. on file at Desert Research Institute Quaternary Sciences Center.

Pippin, L.C., and D.L. Zerga

1981 Cultural Resources Overview for the Nevada Nuclear Waste Storage Investigations, Nevada Test Site, Nye County, Nevada. Desert Research Institute Social Sciences Center Publication 24, Reno.

Fogue, J.E.

1915 The Turquois: A Study of Its History, Mineralogy, Geology, Ethnology, Archaeology, Mythology, Folklore and Technology. Third Memoir Series 12(2):3-162. National Academy of Sciences, Washington, D.C. Reprinted. Rio Grande Press, Glorieta, N.M., 1971.

Public Law (PL)

1966 National Historic Preservation Act of 1966. (PL89-665, 15 October 1966). As amended (PL 95-515).

1969 National Environmental Policy Act of 1969. (PL 91-190).

Rafferty, K.A.

1984 Cultural Resources Overview of the Las Vegas Valley. Contributions to the Study of Cultural Resources Technical Report 13. Bureau of Land Management, Reno.

Raymond, A.W.

1984 Reduction and Curation of Topaz Mountain Obsidian, Utah: A Technological Analysis of Two Lithic Scatters. Unpublished Master's thesis, Department of Anthropology, Washington State University, Pullman.

Rector, C.H., J.D. Swenson, and P.J. Wilke

1979 Archaeological Studies at Oro Grande, Mojave Desert, California. Final Report subinitited to Victor Valley Waste Water Reclamation Authority, Victori!lle, California. 
Reno, R.L.

1987 A Class III Cultural Resources Reconnaissance of the New Right of Way for the Pahute Mesa Road System, Section 1, on the 18-03 Road, Nye County, Nevada. Desert Research Institute Cultural Resources Reconnaissance Short Report Number SR092887-1.

Reno, R.L., and L.C. Pippin

1985 An Archaeological Reconnaissance of Yucca Flat, Nye County, Nevada. Desert Research Institute Social Sciences Center Technical Report 35, Reno.

1986 An Archaeological Reconnaissance of the Groom Range Lincoln County, Nevada. Desert Research Institute Social Sciences Center Technical Report 46, Reno.

Rogers, M.J.

1929 Report of an Archaeological Reconnaissance in the Mojave Sink Region. Archaeological Papers 1(1). San Diego Museum of Man, San Diego.

1939 Early Lithic Industries of the Lower Basin of the Colorado River and Adjacent Desert Areas. Archaeological Papers 3. San Diego Museum of Man, San Diego. Reprinted 1973, Ballena Press, Ramona, California.

Ross, C.S., and R.L. Smith

1955 Water and Other Volatiles in Volcanic Glasses. American Mineralogist 40:1071-1089.

Ruby, J.W.

1970 Culture Contact Between Aboriginal Southern California and the Southwest. Unpublished Ph.D. Dissertation in Anthropology, University of California, Los Angeies.

San Francisco Examiner, May 27, 1933.

Scheetz, B.E., and C.M. Stevenson

1988 The Role of Resolution and Sample Preparation in Hydration Rim Measurement: Implications for Experimentally Determined Hydration Rates. American Antiquity 53(1):110-117.

Schiffer, M.B.

1987 Formation Processes of the Archaeological Record. University of New Mexico Press, Albuquerque.

Seaman, T.J., W.H. Doleman, and R.C. Chapman

1988 The Borderstar 85 Survey: Toward an Archaeology of Landscapes. Report prepared for U.S. Army Corps of Engineers, Fort Worth District. Office of Contract Archaeology, University of New Mexico, Albuquerque.

Self, W.

1980 The Archaeology of Lowe Shelter: A Contribution to the Prehistory of the Western Great Basin. Unpublished Master's thesis, Department of Anthropology, University of Nevada, Reno.

Shutier, R., Jr.

1961 Lost City, Pueblo Grande de Nevada. Anthropological Papers 5. Nevada State Museum, Carson City. 
Singer, C.A., and J.E. Ericson

1977 Quarry Analysis at Bodie Hills, Mono County, California: A Case Study. In Exchange Systems in Prehistory, edited by T.K. Earie and J.E. Ericson, pp. 171-188. Academic Press, New York.

Stahle, D.W., and J.E. Dunn

1982 An Analysis and Application of the Size Distribution of Waste Flakes from The Manufacture of Bifacial Stone Tools. World Archaeology 14(1):84-97.

1984 An Experimental Analysis of the Size Distribution of Waste Flakes from Bifacial Reduction. Technical Paper No. 2. Arkansas Archeological Survey, Fayetteville.

Steel, R.G.D., and J.H. Torrie

1960 Principles and Procedures in Statistics. McGraw Hill, New York.

Stevenson, C.M., J. Carpenter, and B.E. Scheetz

1989 Obsidian Dating: Recent Advances in the Experimental Determination and Application of Hydration Rates. Archaeometry 31(2):193-206.

Steward, J.H.

1938 Basin-Plateau Aboriginal Sociopolitical Groups. Bureau of American Ethnology Bulletin 120. Smithsonian Institution, Washington, D.C. (Reprinted University of Utah Press, Salt Lake City, 1970).

Stoltman, J.B., J.A. Behm, and H.A. Palmer

1984 The Bass Site: A Hardin Quarry/Workshop in Southwestern Wisconsin. In Prehistoric Chert Exploitation: Studies form the Midcontinent, edited by B.M. Butler and E.E. May, pp. 197-225. Occasional Paper No. 2. Center for Archaeological Investigations, Southern Illinois University, Carbondale.

Susia, M.L.

1964 Tule Springs Archaeological Surface Survey. Anthropological Papers 12. Nevada State Museum, Carson City.

Sutton, M.Q.

1981 Archaeology of the Antelope Valley, Western Mojave Desert, California. Manuscript in Sutton's possession.

Teilhard de Chardin, P., and W. Pei

1932 The Lithic Industry of the Sinanthropus Deposits in Choukoutein. Bulletin of the Geological Society of China 11(4):317-365.

Thomas, D.H.

1975 Nonsite Sampling in Archaeology: Up the Creek Without a Site? In Sampling in Archaeology, edited by J.W. Mueller, pp. 61-81. University of Arizona Press, Tucson.

1978 Arrowheads and Atlatl Darts: How the Stones Get the Shaft. American Antiquity 43(3):461-472.

1981 How to Classify the Projectile Points from Monitor Valley, Nevada. Journal of California and Great Basin Anthropology 3(1):7-43. 
Thomas, D.H.

1982 An Overview of Central Great Basin Prehistory. In Man and Environment in the Great Basin, edited by D.B. Madsen and J.F. O'Connell, pp. 156-171. Society for American Archaeology Papers 2. Washington, D.C.

1983 The Archaeology of Monitor Valley 2: Gatecliff Shelter. Anthropological Papers 59(1). The American Museum of Natural History, New York.

1988 The Archaeology of Monitor Valley 3: Survey and Additional Excavations. Anthropological Papers 66(2). American Museum of Natural History, New York.

Tomka, S.A.

1989 Differentiating Lithic Reduction Techniques: An Experimental Approach. In Experiments in Lithic Technology, edited by D.S. Amick and R.P. Mauldin, pp. 137-162. International Series 528. British Archaeological Reports, Oxford.

Tonopah Daily Times, January 19, 1928, and March 28, 1928.

Torrence, $R$.

1983 Time Budgeting and Hunter-Gatherer Technology. In Hunter-Gatherer Economy in Prehistory: A European Perspective, edited by G. Bailey, pp. 11-22. Cambridge University Press, London.

Tuohy, D.R.

1969 Breakage, Burin Facets, and the Probable Technological Linkage Among Lake Mojave, Silver Lake, and Other Varieties of Projectile Points in the Desert West. Anthropological Papers 14:132-152. Nevada State Museum, Carson City.

1974 A Comparative Study of Late Paleolndian Manifestations in the Western Great Basin. In A Collection of Papers on Great Basin Archaeology, edited by R. Elston and L. Sabini, pp. 90-116. Nevada Archaeological Survey Research Papers 5. Reno.

Turner, W.B., and W.E. Klippel

1989 Hunter-Gatherers in the Nashville Basin: Archaeological and Geological Evidence for Variability in Prehistoric La.nd Use. Geoarchaeology 4(1):43-67.

Vaughan, S.J., and C.N. Warren

1987 Toward a Definition of Pinto Points. Journal of California and Great Basin Anthropology 9(2):199-213.

Wallace, W.J.

1958 Archaeological Investigations in Death Valley National Monument 1952-1957. In Current Views on Great Basin Archaeology, pp. 7-22. University of California Archaeological Survey Reports 42.

1962 Prehistoric Cultural Developments in the Southern California Deserts. American Antiquity 28(2):172-180.

1978 A Half Century of Death Valley Archaeology. Journal of California Anthropology 5(2):249-258.

Wallace, W.J., and E.S. Taylor

1959 A Preceramic Site at Saratoga Springs, Death Valley National Monument, California. Contributions to California Archaeology 3(2):1-13. Los Angeles. 
Warren, C.N.

1967 The San Dieguito Complex: A Review and Hypothesis. American Antiquity 32(2):168-185.

1980 The Archaeology and Archaeological Resources of the Amargosa-Mojave Basin Planning Units. In A Cultural Resources Overview for the Amargosa-Mojave Basin Planning Units, by C.N. Warren, M. Knack and E.T. Warren, pp. 1-134. Unpublished report submitted to the Bureau of Land Management Desert Planning Staff, Riverside, California.

Warren, C.N., K. Bergin, D. Ferraro, and K. Olson

1978 Archaeological Excavation at the Valley of Fire. Prepared for the Nevada State Park System by the Archaeological Research Center, Museum of Natural History, University of Nevada, Las Vegas.

Warren, C.N., and R.H. Crabtree

1986 Prehistory of the Southwestern Area. In Great Basin, edited by Warren L. d'Azevedo, pp. 183-193. Handbook of North American Indians, vol. 11, William G. Sturtevant, general editor. Smithsonian Institution, Washington, D.C.

Webster, G.S.

1980 Recent Data Bearing on the Question of the Origins of the Bow and Arrow in the Great Basin. American Antiquity 45(1):63-66.

Wheat, C.I.

1939 Trailing the Forty-Niners Through Death Valley. Sierra Club Bulletin 24(3):74-108. Wheeler, G.M.

1872 Preliminary Report of Explorations in Nevada and Arizona. In Preliminary Report Concerning Explorations and Surveys Principally in Nevada and Avizona, edited by A.A. Humphreys. U.S. Government Printing Office, Washington, D.C.

Wheeler, S.M.

1940 Preliminary Report of Reconnaissance in the Forty-Mile Canyon Area. Ms. on file, Nevada State Museum, Carson City and Desert Research Institute Social Sciences Center, Reno.

White, J.P.

1968 Fabricators, Outils Ecailles or Scalar Cores? Mankind 6(12):658-666.

Wiant, M.D., and H. Hassen

1985 The Role of Lithic Resource Availability and Accessibility in the Organization of Lithic Technology. In Lithic Resource Procurement: Proceedings from the Second Conference on Prehistoric Chert Exploitation, edited by S.C. Vehik, pp. 101-114. Occasional Paper No. 4. Center for Archaeological Investigations, Southern Illinois University, Carbondale.

Wiessner, P.

1974 A Functional Estimator of Population from Flood Area. American Antiquity 39(2):343-350. 
Worman, F.C.V.

1964 Anatomy of the Nevada Test Site. Viniversity of California Los Alamos Scientific Laboratory Report. Los Alamos, New Mexico.

1969 Archaeological Investigations at the U.S. Atomic Energy Commission's Nevada Test Site and Nuclear Rocket Development Station. University of California Los Alamos Scientific Laboratory Report LA4125. Los Alamos, New Mexico.

Yellen, J.E.

1977 Archaeological Approaches to the Present. Academic Press, New York. 

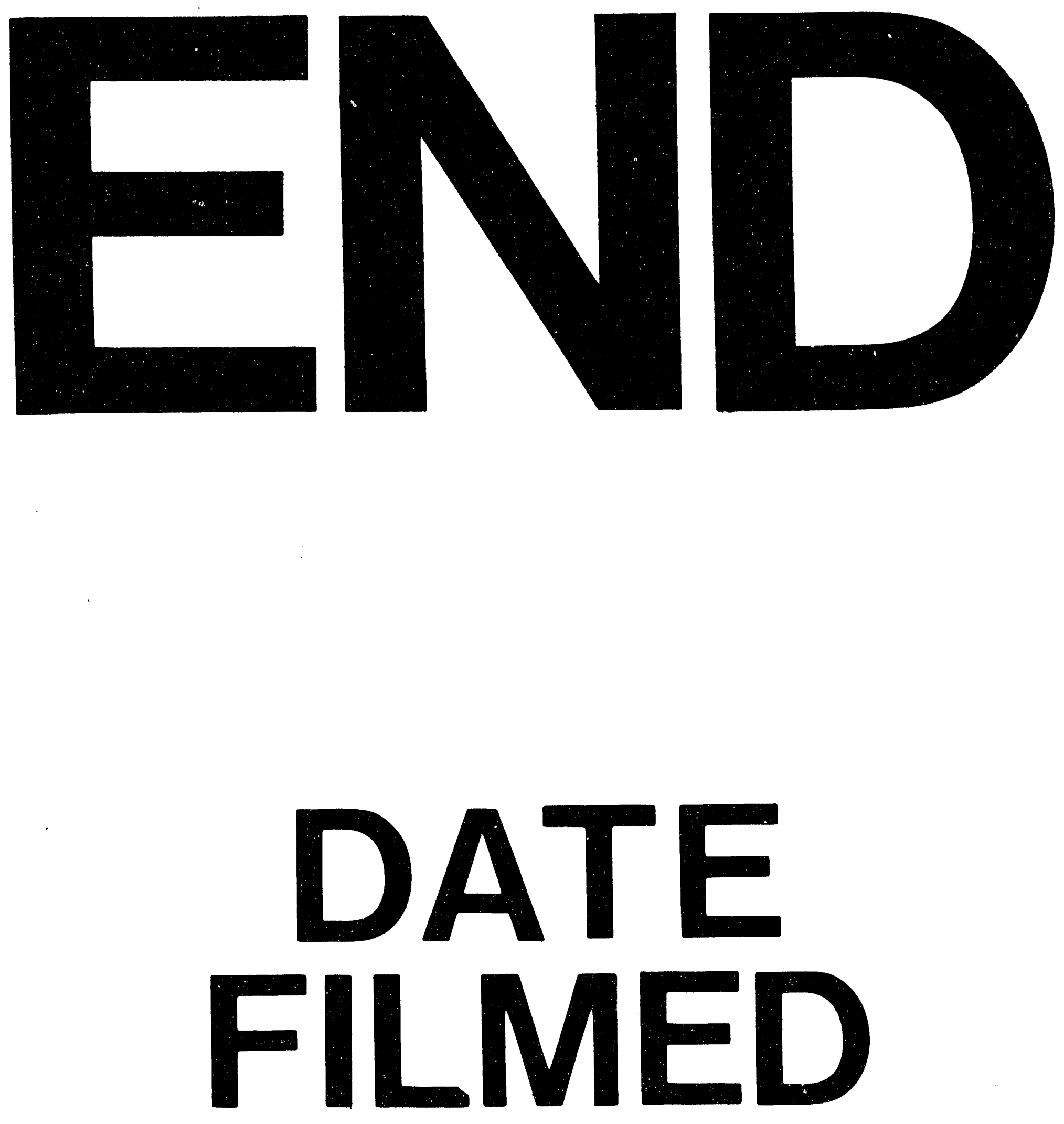

1

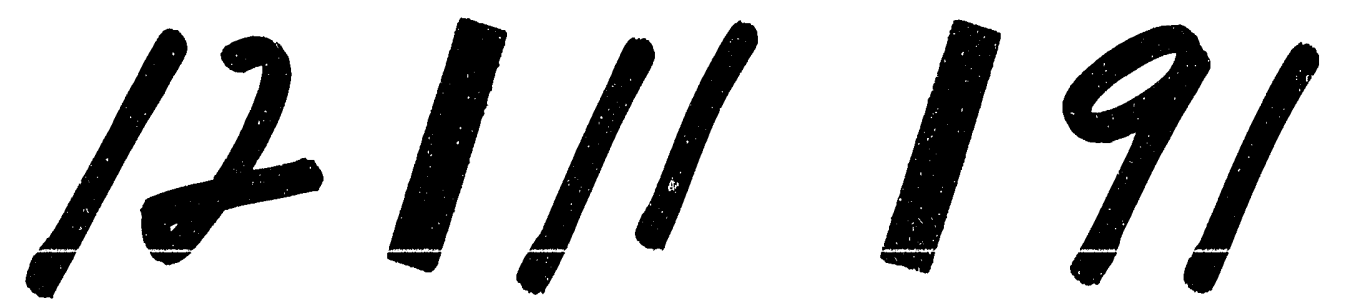


